\title{
A FRAMEWORK FOR ASSESSMENT OF THE DECISION- MAKING PROCESS OF WINTER ROAD MAINTENANCE OPERATIONS
}

\author{
A thesis submitted to \\ the Faculty of Graduate and Postdoctoral Affairs \\ in Partial Fulfillment of the requirements of the degree \\ Master of Applied Science in Civil Engineering \\ by \\ Mohamed M. Alkoka \\ Department of Civil and Environmental Engineering \\ Carleton University
}

Ottawa-Carleton Institute of Civil and Environmental Engineering

May 2011

(C) 2011, Mohamed M. Alkoka 
Library and Archives

Canada

Published Heritage Branch

395 Wellington Street Ottawa ON K1A ON4

Canada
Bibliothèque et

Archives Canada

Direction du

Patrimoine de l'édition

395 , rue Wellington

Ottawa ON K1A ON4

Canada
Your file Votre référence

ISBN: 978-0-494-83062-8

Our file Notre référence

ISBN: 978-0-494-83062-8
NOTICE:

The author has granted a nonexclusive license allowing Library and Archives Canada to reproduce, publish, archive, preserve, conserve, communicate to the public by telecommunication or on the Internet, loan, distribute and sell theses worldwide, for commercial or noncommercial purposes, in microform, paper, electronic and/or any other formats.

The author retains copyright ownership and moral rights in this thesis. Neither the thesis nor substantial extracts from it may be printed or otherwise reproduced without the author's permission.
AVIS:

L'auteur a accordé une licence non exclusive permettant à la Bibliothèque et Archives Canada de reproduire, publier, archiver, sauvegarder, conserver, transmettre au public par télécommunication ou par l'Internet, prêter, distribuer et vendre des thèses partout dans le monde, à des fins commerciales ou autres, sur support microforme, papier, électronique et/ou autres formats.

L'auteur conserve la propriété du droit d'auteur et des droits moraux qui protège cette thèse. $\mathrm{Ni}$ la thèse ni des extraits substantiels de celle-ci ne doivent être imprimés ou autrement reproduits sans son autorisation.
In compliance with the Canadian Privacy Act some supporting forms may have been removed from this thesis.

While these forms may be included in the document page count, their removal does not represent any loss of content from the thesis.
Conformément à la loi canadienne sur la protection de la vie privée, quelques formulaires secondaires ont été enlevés de cette thèse.

Bien que ces formulaires aient inclus dans la pagination, il n'y aura aucun contenu manquant.

\section{Canadä}




\begin{abstract}
Road networks are the most prevalent and reliable element of the transportation systems. Roads provide freedom of movement, are continually available, and form the backbone of the economy. Road maintenance, including snow and ice control, is an essential part of ensuring a safe and efficient road network. Winter road maintenance operation is a series of activities performed at various times to keep roads safe and passable during severe winter conditions. Winter road maintenance components must be coordinated to allow operation's managers to make the right decisions at the right time. Decisions made for winter road maintenance operations are dependent on factors such as weather conditions, road temperature, de-icing material, and equipment. Many decisions are made for the timely mobilization of resources for winter maintenance activities such as salting or snow removal. Given the uncertainty associated with the variability of winter, it is inevitable that maintenance decisions will be made with a proportion of inaccuracy. However, untimely or ill-informed decisions result in unnecessary over usage of resources, or deficient maintenance efforts. This thesis is focused on reducing the margin of decision error by establishing a framework or a methodology for measuring and assessing decision effectiveness.
\end{abstract}




\section{ACKNOWLEDGMENT}

I would like to acknowledge my dear professors at Carleton University, and most importantly my supervisor Professor A. O. Abd El Halim, and Professor Y. Hassan for their time and efforts during the course of this thesis. I must also acknowledge my wife, Leenah, for never doubting and always supporting my endeavours, and a special dedication for my parents for setting in motion my wheel of life.

I would like to thank the City of Toronto and the wonderful staffers who helped provide data for my research.

Thank you. 


\section{TABLE OF CONTENTS}

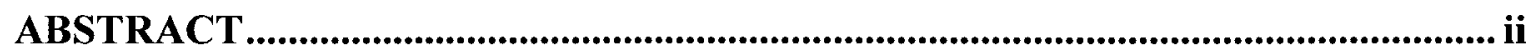

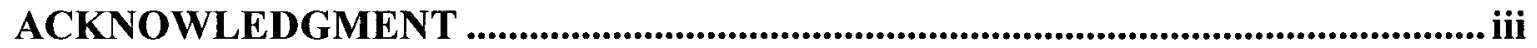

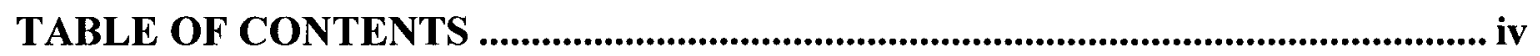

LIST OF TABLES ................................................................................................................. vi

LIST OF FIGURES ....................................................................................................... vii

LIST OF ABBREVIATIONS ........................................................................................ viii

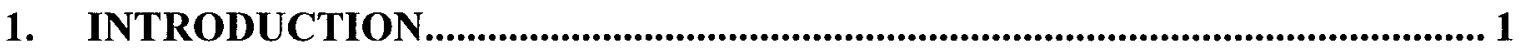

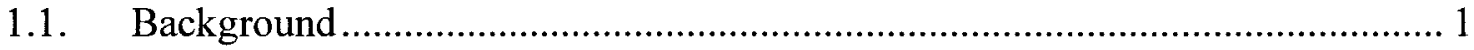

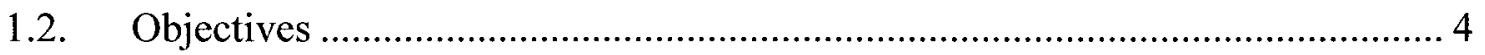

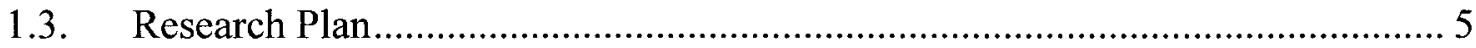

1.4. Scope of The Research .......................................................................... 7

1.5. Thesis Organization ................................................................................. 7

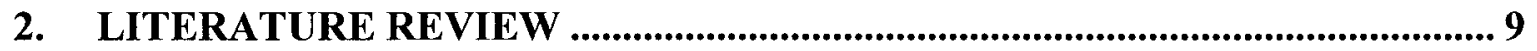

2.1. Winter Road Weather, Monitoring and Forecasting .......................................... 9

2.2. Winter Road Maintenance Operations................................................................. 13

2.3. Materials for Snow and Ice Control.............................................................. 14

2.4. Material Application Techniques............................................................... 19

2.5. Equipment for Winter Operations............................................................... 20

2.6. Winter Maintenance Policy and Level of Service ........................................... 21

2.7. The Human Side of Decision Making ………….............................................. 25

3. DECISION SUPPORT FOR WINTER OPERATIONS..................................... 27

3.1. Operational Routes for Decision Support ...................................................... 27

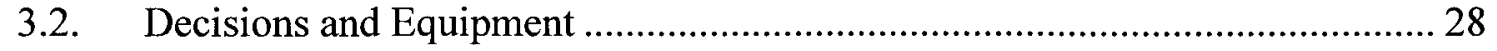


3.3. Operational Information for Decision Making ....................................... 30

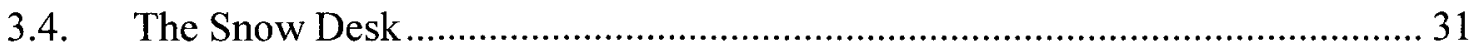

3.5. Automated Decision Support Systems ................................................... 32

3.6. Winter Maintenance Management Systems ............................................... 33

4. DECISION MAKING FRAMEWORK....................................................... 35

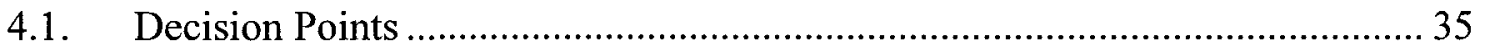

4.2. Decision Making Hierarchy ................................................................... 37

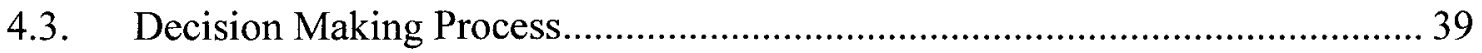

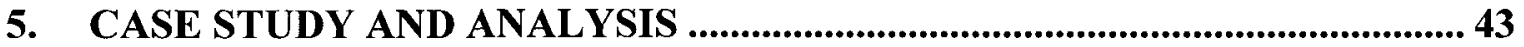

5.1. Transportation Services Division - Background .................................... 43

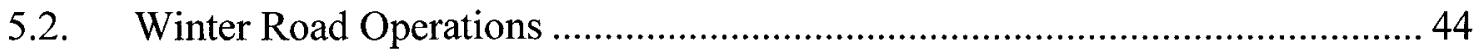

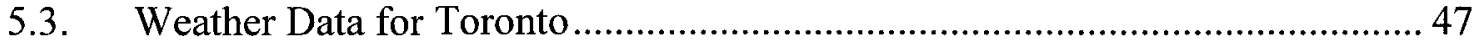

5.4. Winter Operation's Data from the City of Toronto...................................... 51

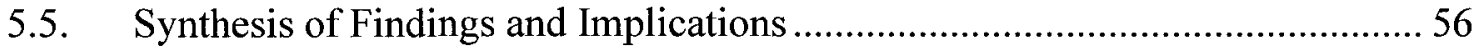

5.5.1. Analysis for Anti-icing Decisions.............................................. 57

5.5.2. Analysis for Salting Decisions................................................. 59

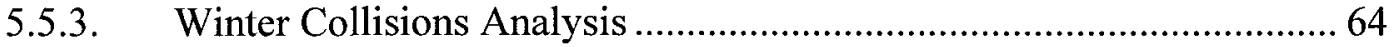

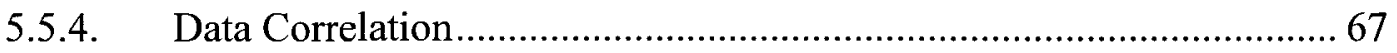

6. CONCLUSIONS AND RECOMMENDATIONS............................................ 69

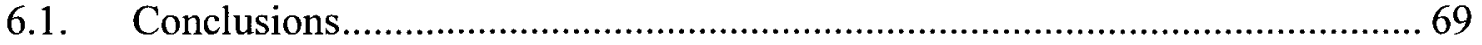

6.2. Recommendations and Future Work .................................................... 72

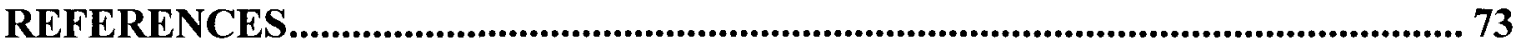

APPENDIX A

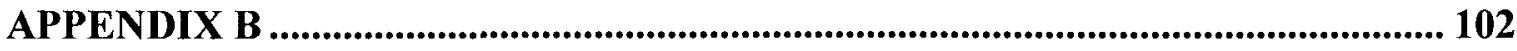




\section{LIST OF TABLES}

Table 2.1: De-icing Chemicals Temperature \& Concentration ....................................... 19

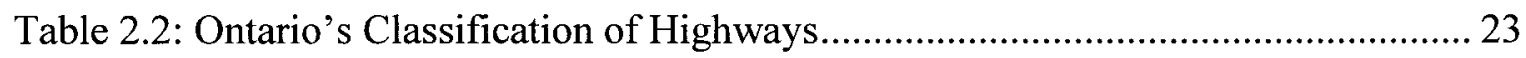

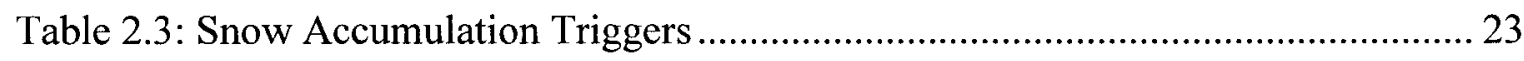

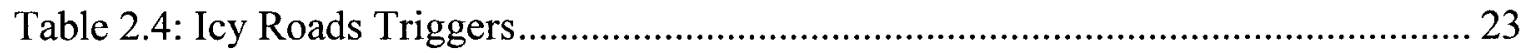

Table 2.5: City of Ottawa Maintenance Quality Standards - Roads ................................ 24

Table 5.6: Toronto's Road Classification - Salting Chart.................................................. 46

Table 5.7: Snow Storm Type and Frequency ............................................................. 50

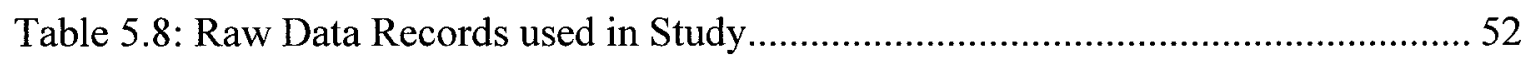

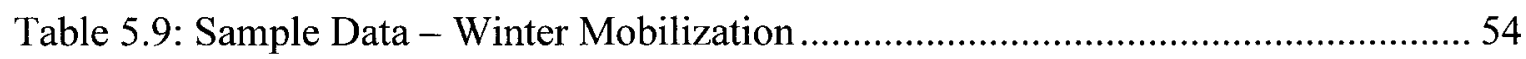

Table 5.10: Winter Mobilization and Weather Data Summary .......................................... 55

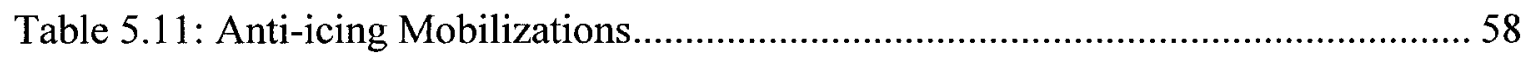

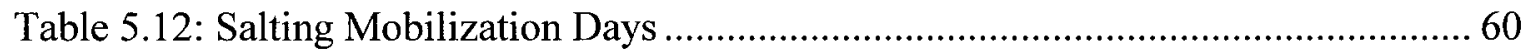

Table 5.13: Salting Mobilization Days vs. Snow Days ……………………………........ 61

Table 5.14: Level of Effort - Kilometres per Centimetre of Snow Salted ........................ 63

Table 5.15: Level of Mobilization vs. Theoretical Salting Capacity ...................................64

Table 5.16: Winter Season Collision by Road Surface Condition.....................................65

Table 5.17: Kilometres per Centimetre of Snow and Winter Collisions ............................ 66

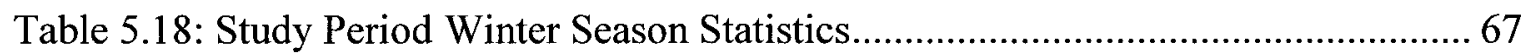

Table 5.19: Winter Season Statistics -Correlation Matrix ……........................................... 68 


\section{LIST OF FIGURES}

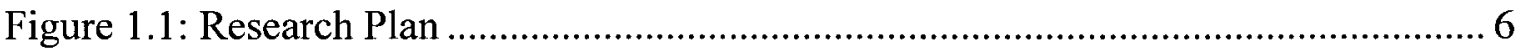

Figure 2.2: Vehicle-mounted Infrared Thermometer....................................................... 11

Figure 2.3: Typical Road Weather Station ............................................................... 12

Figure 2.4: Typical Phase Diagram ………………...................................................... 16

Figure 2.5: Phase Diagram of Common Deicing Chemicals ............................................ 17

Figure 4.6: Decision Points for Pavement Temperature ................................................... 36

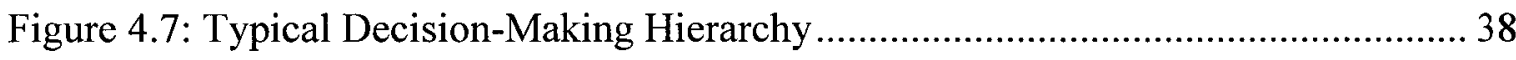

Figure 4.8: Typical Pre-Storm Decision Making Process ........................................... 40

Figure 4.9: Typical in-Storm Decision Making Process.................................................... 42

Figure 5.10: Winter Mobilization Procedure ................................................................ 47

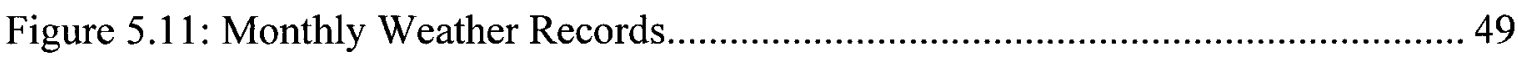

Figure 5.12: Monthly Snow Storm Frequency …………............................................. 51

Figure 5.13: Winter Operations Raw Data -Screen Capture............................................ 52

Figure 5.14: Kilometres Driven vs. Collisions Variations.................................................6 


\section{LIST OF ABBREVIATIONS}

\begin{tabular}{ll} 
AADT & Average Annual Daily Traffic \\
AASHTO & American Association of State Highway \& Transportation Officials \\
AHUA & The American Highway Users Alliance \\
AVL & Automatic Vehicle Location \\
CaCl & Calcium Chloride \\
CMA & Calcium Magnesium Acetate \\
CMC & Canadian Meteorological Centre \\
DART & De-icing Anti-icing Response Treatment system \\
FHWA & Federal Highway Administration (USA) \\
GEM & Global Environmental Multiscale \\
GIS & Geographic Information System \\
GPS & Global Positioning System \\
IRT & Infrared Thermometers \\
KAc & Potassium Acetate \\
km & Kilometres \\
LAN & Local Area Networks \\
LOS & Level Of Service \\
MESS & Maintenance Decision Support System \\
MgCl & Model of the Environment and Temperature of Roads \\
\hline
\end{tabular}




$\begin{array}{ll}\text { MTO } & \text { Ontario Ministry of Transportation } \\ \text { NaCl } & \text { Sodium Chloride } \\ \text { NCHRP } & \text { National Cooperative Highway Research Program (USA) } \\ \text { RWIS } & \text { Road Weather Information System } \\ \text { TAC } & \text { Transportation Association of Canada } \\ \text { TMMS } & \text { Toronto Maintenance Management System } \\ \text { Transport Canada } & \text { The Federal Ministry of Transportation of Canada } \\ \text { WAN } & \text { Wide Area Networks } \\ \text { WMMS } & \text { Winter Maintenance Management System }\end{array}$




\section{CHAPTER 1 \\ INTRODUCTION}

\subsection{Background}

Road networks plays major role in the movement of people and goods while considered the most commonly used element of the national transportation systems. Even with all the advancements in air and sea travel, roads are the backbone of any economy. Roads take this level of importance for their ubiquity, permanency, and high capacity. They provide freedom of movement, mobility, and are continually available for road users. Road networks accommodate several modes of transportation, commercial and private including trucks, buses, passenger vehicles, bicycles, walking and even horse and carriage.

The economies of scale for transportation are quite significant, according to Transport Canada [Transport Canada, 2008] in fiscal year 2008-2009, all levels of government combined spent $\$ 35.4$ billion on transportation of which $71 \%$ ( $\$ 25.1$ billion) were spent on roads. The remaining $29 \%$ ( $\$ 10.3$ billion) were spent collectively on other modes of transportation such as public transit, marine, air and multimodal. The 2008 report by Transport Canada indicated that the different modes of transportation activities (e.g. road, air, rail) would attain an annual total cost of as much as $\$ 233$ billion with road transportation alone accounting for $86 \%$ (\$201 billion) of the total cost including the perceived social cost of transportation [Transport Canada, 2008]. According to same 
report, the social costs associated with the impacts of transportation activities in the year 2000 , were estimated to be up to $\$ 39.5$ billion, measured in five areas, listed in the order of importance: 1) accidents, 2) air pollution, 3) congestion, 4) greenhouse gas emissions and 5) noise [Transport Canada, 2008].

Regular maintenance of roads is necessary to ensure continual operation of the road network, and for the safe and timely movement of people and goods. Road maintenance includes penetrative and restorative activities such as crack sealing, pothole repair, minor and major resurfacing. On the other hand, routine maintenance includes activities such as sweeping, debris removal, litter pick up, catch basin and ditch cleaning, grass cutting and roadside vegetation control, and snow and ice control during the months of winter.

The cost for snow and ice removal exceeds $\$ 2$ billion annually in the United States alone [Minsk, 1998]. It is also estimated that the various agencies in Canada spent, in 1998 , nearly $\$ 1.3$ billion annually on their winter maintenance operations [Jones, 2003]. The delay, failure, or the inability to provide winter road maintenance will have significant effects economically, socially, and environmentally. The American Highway Users Alliance (AHUA) [American Highway, 2010] commissioned a study to measure the economic costs of disruptions caused by snowstorms. The study shows that there is "significant expense, both directly and indirectly, a major storm has on businesses and government because of impassable roads, as much as $\$ 300-700$ million in some states for 
just a one day shutdown" [American Highway, 2010]. The direct cost was attributed to loss of income and sales, while the indirect component is the cost associated with the rippling effect through the economy that would have been stimulated by the wages and sales that were lost [American Highway, 2010].

The effects of winter weather on Canadian roads are also significant for municipal road authorities. For example, according to information obtained from the City of Toronto [Toronto, 2009], the City allocates an annual budget of nearly $\$ 80$ million for roadway winter operations; broken down to approximately $50 \%$ for road plowing, $30 \%$ for road salting, and $20 \%$ for sidewalk clearing. In general, winter road maintenance activities will form the largest single item in a road maintenance budget for Canadian municipalities.

Winter road maintenance operation is a series of activities and tasks performed at various stages of a snowfall or ice event to produce safe and passable roadways. Winter maintenance consists of several operations which must be coordinated to allow operations managers to make the right decisions at the right time [AASHTO, 1999]. Decisions made for winter road maintenance operations are dependent on factors such as weather conditions, precipitation type, time of the day, road temperature, de-icing material, equipment, and labour resources. Many decisions need to be made for the timely mobilization of resources for winter maintenance activities such as salting or snow plowing. Given the inherent complexity of the decision making process and the 
uncertainty associated with the variability of winter conditions, it is expected that inaccurate decisions for winter road maintenance will be made resulting in increasing costs and economic losses. Therefore, there is a need to establish a systematic framework for decision making for winter road maintenance operations. Furthermore, as decisions are made and executed in the field, they are rarely evaluated for effectiveness against a standard or a benchmark. This generates questions such as: Was the effort exerted upon executing a decision properly apportioned to the road condition? Was the equipment mobilized at the right time? Was the salt application suited for the amount of snow accumulation and road temperature? Such questions point to the need to have benchmarks for measuring the effectiveness of winter road maintenance decisions. Consequently there is a need to further investigate the decision-making process for winter road maintenance operations in order to develop a framework for systematic decision making, and to identify better evaluation methods in an attempt to quantify the decisions made for winter road maintenance.

\subsection{Objectives}

Based on the preceding discussions, the objectives of this thesis are as follows:

- To carry out literature review to identify key elements contributing to the decision-making process of winter road maintenance operations and to determine any deficiencies that might exist.

- To propose a framework for a systematic decision-making process for winter road maintenance operation. 
- To demonstrate the benefits of the developed framework by analyzing the relationship between winter maintenance operational mobilizations, weather conditions, and winter related collisions, using actual post-event operational data.

- To identify a better methodology to quantify efforts resulting from winter maintenance operational decisions.

\subsection{Research Plan}

To achieve the objectives of this thesis, the research plan started with a literature review of winter road maintenance operations to identify key elements contributing to its decision-making process. Elements were explored for their influence over the operation; such elements included road weather monitoring and forecasting, pavement temperature, materials' types and application techniques. Based on the understandings obtained through the identification of the winter maintenance operation's key elements, a framework for a systematic decision-making process was proposed and shown in a flowchart format. The process includes process flow for pre-storm and in-storm decisionmaking.

Weather information, for six winter seasons from 2004 to 2010 , were obtained from Environment Canada, including daily temperature and snowfall readings. In addition, actual post-event winter maintenance operations data from the City of Toronto were collected, cross-referenced with weather information, and reduced into a working 
data set. The data set is focused on the deployment of maintenance vehicles as representation of mobilizations' decisions. Analysis of the data set was performed to examine the implication of decision actions, and to determine relationships between winter maintenance operational mobilizations, weather conditions, and winter related collisions. The analysis shows benefits of the proposed framework on salting and antiicing activities. Finally, based on data analysis, identify a methodology to quantify efforts resulting from winter maintenance operational decisions. This provides road maintenance practitioners with improved decision making for winter operations. A simplified flow chart is shown in Figure 1.1.

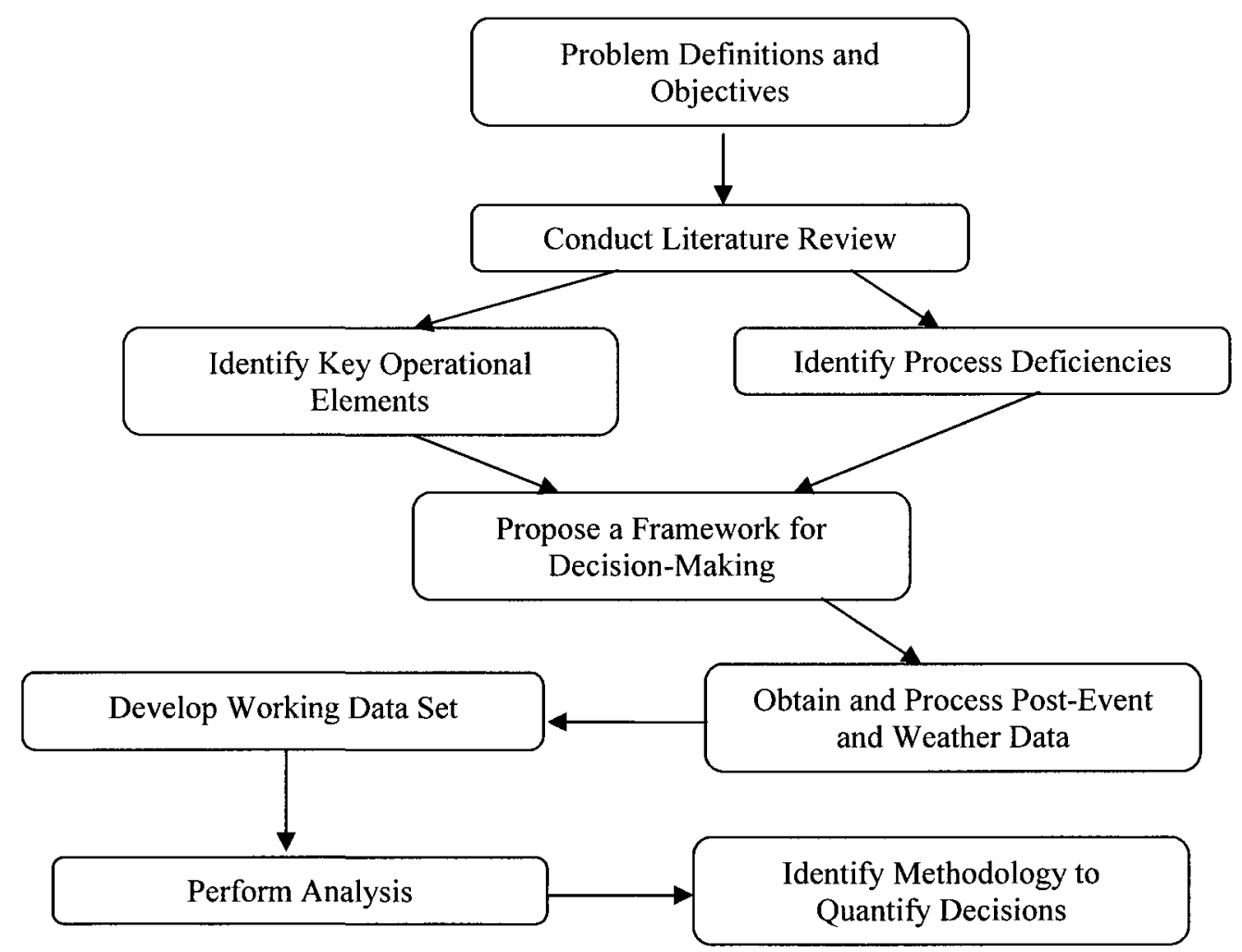

Figure 1.1: Research Plan 


\subsection{Scope of The Research}

The scope of the presented research is limited to road winter maintenance operations directly related to snow and ice control. More specifically the type of maintenance activities adopted in this thesis is the one related to the utilization of material application (salting) and direct liquid application (anti-icing) to road surfaces in Ontario. The analysis will be conducted on data collected from one of the four districts for the Road Operations unit within the Transportation Services Division of the City of Toronto. The study period is limited to six winter seasons from 2004-2005 to 2009-2010.

\subsection{Thesis Organization}

The thesis is comprised of six chapters; Chapter 1 provides an introduction into the importance of road transportation networks and the impact winter road maintenance has on the economy, and outlines the research needs and objectives. Chapter 2 provides a literature review of winter maintenance including road weather forecasting and monitoring. The chapter also explains the role of snow and ice control materials and techniques for road application. In addition, the chapter discusses factors in the operation such as equipment, level of service, and maintenance policies. Chapter 3 discusses decision support for winter operations and associated systems such as planned operational routes, equipment utilization, operational data collection and centralized management systems. Chapter 4 presents the main steps of the proposed framework for decision making process for winter operations and showing typical sequential steps for 
winter maintenance operation decisions. Chapter 5 describes the case study subject, data collections, and analysis showing possible links between winter maintenance operational mobilizations, weather conditions, and winter related collisions, while Chapter 6 provides important conclusions and recommendations. 


\section{CHAPTER 2}

\section{LITERATURE REVIEW}

\subsection{Winter Road Weather, Monitoring and Forecasting}

Winter maintenance programs are dependent on climate and weather conditions occurring in the area. This makes the study of weather patterns and historic data rather important. Climate conditions refer to the average weather events that occur over a long period of time, as well as the frequency of extreme events. Recurring site conditions such as cold spots, or windy areas, are referred to as microclimates and require special attention [Blackburn, 2004]. While weather conditions refer to the "measurable or identifiable meteorological events that occur at a given site or in a given area at a particular point in time." [Blackburn, 2004]. They include conditions such as visibility, precipitation, temperature, relative humidity and are the most crucial elements when determining an effective winter maintenance strategy. Current weather conditions vary in their effect on the road, based on local topography such as hills, curves and bridges. The above, combined with traffic conditions, influence winter maintenance operational decisions, such as type of materials and equipment to be used, and timing and priority of treatments.

Road Weather is a term used to refer to the weather on or near roadways that specifically affects the function of the road. Air temperature, pavement temperature, relative humidity, wind speed, precipitation type and rate of intensity, and cloud cover 
have a direct effect on the chemical process being used to control snow and ice. Therefore, monitoring road weather helps to identify the opportune window of time for de-icing, anti-icing, or snow removal operations.

The surface of the road is the contact plane for snow and ice; it has been identified as a key element affecting the formation of ice on the road and the overall behaviour of materials used for snow and ice control. Pavement temperature directly influences the formation, development and breaking of the bond between fallen or compacted precipitation and the road surface, as well as the effectiveness of chemical treatments [AASHTO, 1999].

Pavement temperature can be monitored with non-contact Infrared Thermometers. They are usually used by road authorities and are of two types: handheld and vehiclemounted, shown in Figure 2.2. The hand held device is for manual use by an operator and gives intermittent readings. The vehicle-mounted device is permanently installed to point to the road surface and to display the readings on an in-dash display. Such readings may provide enough information to make a decision such as calling out salt spreaders. For example, within the City of Ottawa and City of Toronto nearly all of the patrol and supervisor vehicles are equipped with vehicle-mounted infrared thermometers. 


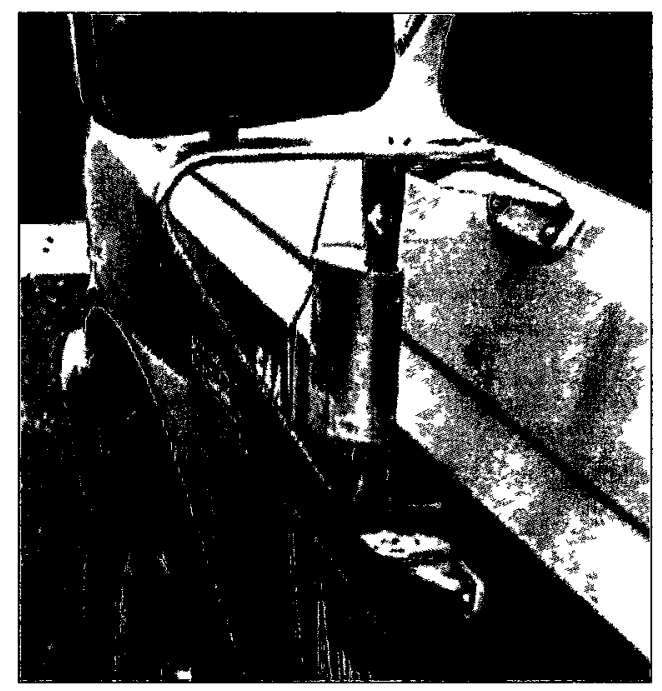

Figure 2.2: Vehicle-mounted Infrared Thermometer

(Roadwatch Infrared Road Temperature Sensor, photo by author)

A Road Weather Information System (RWIS) is a "collection of instruments to measure the meteorological and environmental variables that have been found to have the greatest value for microclimatic assessment and the communication system necessary to collect this information and transmit it to a central location" [Minsk, 1998]. RWIS includes automated micro-weather reporting stations equipped with a collection of sensors in and below the road surface, and on nearby roadside towers. The system collects sensor readings and transmits them through a communication network to a central computer server or a data processing centre. The data collected is then accessed by users for a variety of purposes. RWIS data include air temperature, relative humidity, road surface temperature, subsurface temperature, road moisture, chemical presence, precipitation, wind speed and direction. RWIS stations may include additional equipment such as video cameras and ice-sensitive photo sensors. RWIS stations are typically located in a representative location of the coverage area, with a spacing range of 
approximately 30 to 50 kilometres [FHWA, 2005]. RWIS data can be used in real-time applications to remotely monitor pavement conditions, as part of a process to decide on treatment type and time. RWIS data is also used by trained forecasters to produce roadspecific weather reports and forecasts. The data may be used to determine area-specific weather patterns and supplement atmospheric weather forecasting [FHWA, 1996]. A typical road weather station is shown in Figure 2.3.

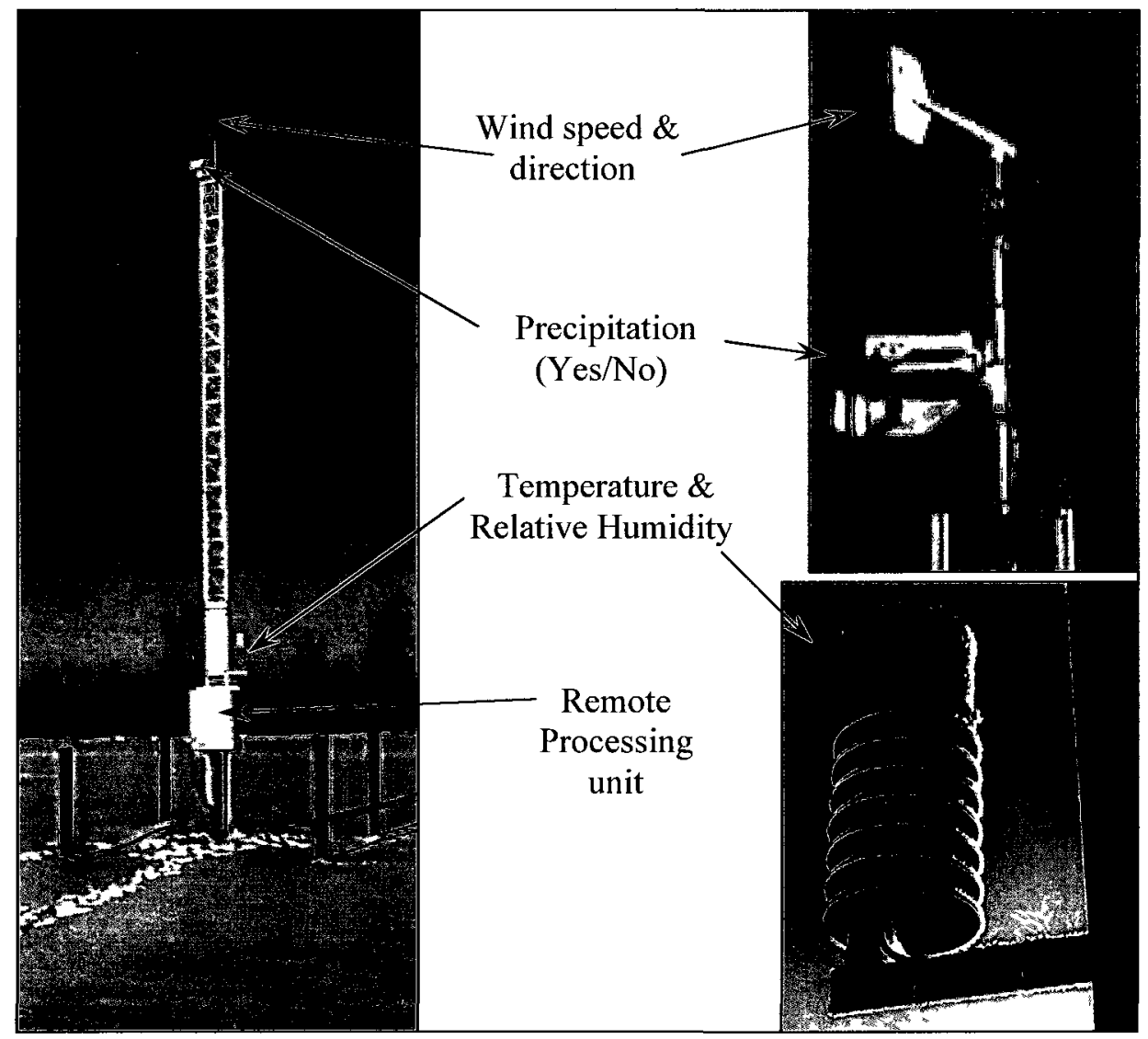

Figure 2.3: Typical Road Weather Station

(Photos by the author) 
The information generated by RWIS is used for real-time condition monitoring and forecasting road conditions for the purpose of snow and ice control. There are several private companies and public agencies that provide road condition forecasting using a number of different forecasting models, such as the Canadian heat balance model, METRo. "The main part of such a system is a new physically based numerical Model of the Environment and Temperature of Roads (METRo), which has close connections with the Global Environmental Multiscale (GEM) operational regional numerical weather prediction model run at the Canadian Meteorological Centre (CMC) in Montreal. METRo was first implemented at the Ottawa Regional Centre in October of 1999, and is currently in operational use at other Canadian weather centers. METRo incorporates a full roadcondition forecasting system that can predict the road surface temperature as well as the pavement condition." [Crevier \& Delage, 2001]. Road weather service providers, with the advent of the internet are able now to provide web-based access to their clients with up-to-date detailed weather forecasts, road condition forecasts, and concurrent road temperature readings relative to forecast time. This serves as an added tool to support operational decision making.

\subsection{Winter Road Maintenance Operations}

Winter road maintenance operation is a series of activities and tasks performed at various stages of a snowfall or ice event to produce safe and passable roadways. Winter maintenance consists of many components, including: 1) level of service, 2) policy and standards, 3) material types, 4) road and weather conditions, 5) equipment, 6) labour, and 
7) technology and methodology. These components must be coordinated to allow operations managers to make the right decision at the right time [AASHTO, 1999]. The winter road maintenance operation's objective is to remove snow and ice from road surfaces to make it safe for driving motorists. Snow and ice control can be achieved by mechanical means, which involve physically moving snow and ice from the travelled lanes to elsewhere. Mechanical snow removal includes techniques such as snow plowing, snow blowing and snow sweeping [Minsk, 1998]. Snow and ice control can also be achieved by chemical means, whereby the composition of snow and ice is changed from total water that freezes at zero degrees Celsius to a mixture of water and chemicals that freeze at a temperature below zero degrees Celsius. The lower temperature is determined by the type of chemical used, its concentration in the solution and the ambient temperature at the time. This process is known as 'de-icing', "De-icing is a snow and ice control strategy of removing compacted snow or ice already bonded to the pavement surface by chemical or mechanical means or a combination of the two" [NCHRP 526, 2004].

\subsection{Materials for Snow and Ice Control}

Materials used for snow and ice control may be separated into two categories: 1) Abrasives, and 2) Chemicals. Abrasives are designed to create or increase friction on surfaces covered with snow and ice. Abrasives for snow and ice control include: sand, stone dust, crushed rocks and volcanic cinders. They are typically used when pavement temperatures are lower than the effective temperature of de-icing chemicals. Abrasives 
are also used on gravel roads and in areas where abrasives are deemed to be a more viable environmental choice over de-icing chemicals. However, abrasives are rarely used by themselves without any other additives. It is common to mix other de-icing materials, at a minimum of $2 \%$ to $5 \%$, such as salt or calcium chloride, with abrasives in order to prevent the stockpiles from freezing. This also makes the material mixture more workable for transportation and delivery as well as the on-road spreading application. It is also possible that the small percentage of salt in the sand helps the sand stick to ice surfaces creating a rough surface, thereby increasing surface friction on the road. [Minsk, 1998]

Chemicals for snow and ice control are used to change the freezing point of snow and ice to keep it in a fluid state to drain it away from the road surface. Chemicals that are freeze-point depressants are known as de-icing chemicals. De-icing chemicals are mainly in the family of chlorides and Acetates. The following are five of the most commonly used de-icing chemicals: 1) Sodium Chloride (NaCl), 2) Calcium Chloride $(\mathrm{CaCl})$, 3) Magnesium Chloride $(\mathrm{MgCl})$, 4) Potassium Acetate (KAc), 5) Calcium Magnesium Acetate (CMA). These chemicals could be naturally available and manmade. Sodium Chloride, in the form of road salt has been the most widely used de-icer in both dry and liquid applications [TAC 1999]. However, road salt and other de-icing chemicals have limitations, and understanding their chemical properties will help establish when and where to use a certain chemical within winter operation. 
It should be noted that de-icers must be in a solution to work. When using a dry form of the material, it is virtually inactive and must be dissolved in water (mixed with snow) to activate it and initiate the chemical reaction to release the chemical energy that changes freezing temperature of the solution. This process is dependant on ambient temperature, solution concentration and atmospheric pressure. However, since the material is used on roads in an open air environment, the control elements are reduced to only two; 1) temperature and 2) solution concentration. Material phase changes in physical state, at various concentrations, are represented by Phase Diagrams. A typical Phase Diagram is shown in Figure 2.4. [FHWA 1996]

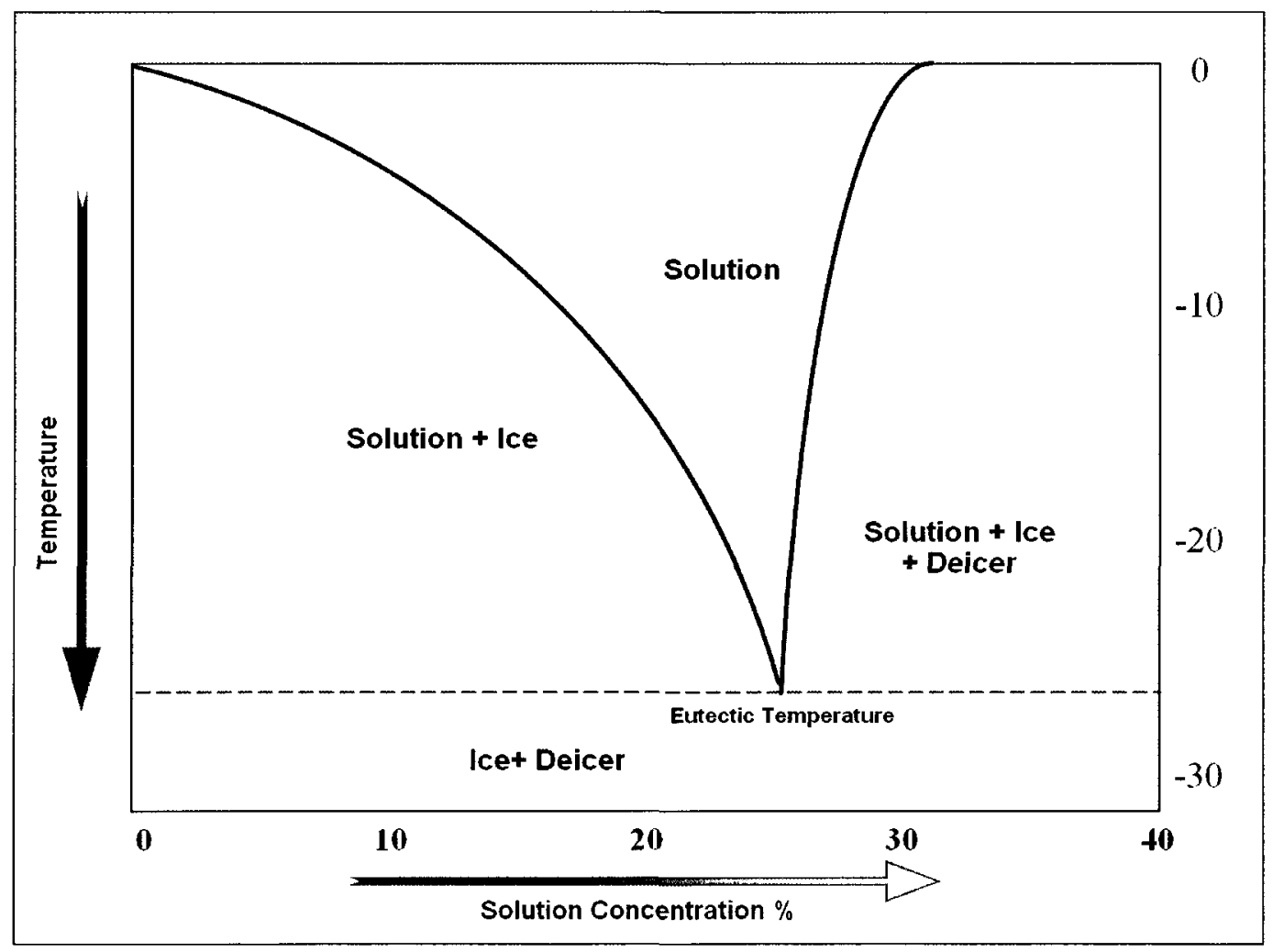

Figure 2.4: Typical Phase Diagram

(Adapted from Federal Highway Administration [FHWA 1996]) 
The phase diagram shows a typical solubility curve of a de-icer chemical. The lowest point on the curve signifies the Eutectic Temperature, which is "the temperature at which a chemical solution freezes completely without change in composition" [Minsk, 1998]. Figure 2.5 shows the superimposed phase diagrams of the five most common chemicals. It is noted that the general shape of the solubility curve is similar. However, the vertical depth of the curve varies, which varies the envelope where each chemical is most effective for melting snow and ice [FHWA 1996].

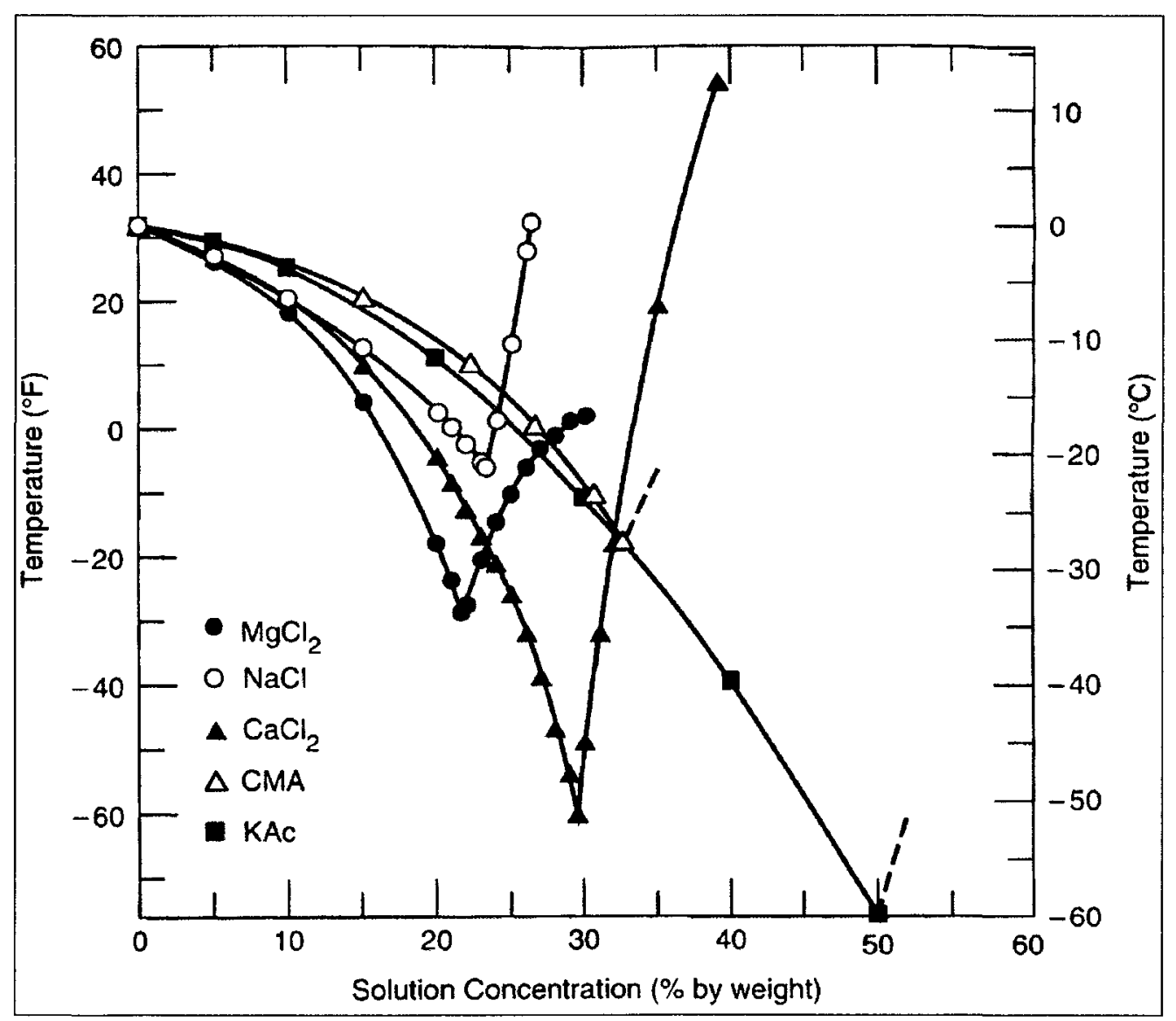

Figure 2.5: Phase Diagram of Common Deicing Chemicals (Source: Federal Highway Administration, [FHWA 1996]) 
The Eutectic Temperature is the lowest temperature that a de-icing chemical will, theoretically, still be able to melt ice, and it is the same point where more concentration of the chemical will not lower the freezing point of the solution. The chemical concentration at this point, is known as the Eutectic concentration, beyond which, higher chemical concentration into the solution will cause chemical precipitation and change the freezing point upward [FHWA 1996].

Nevertheless, in actual field conditions, the Eutectic Temperature is not a practical decision point. The chemical would be too volatile for its purpose, and any slight variation in concentration would change effectiveness of the de-icer. Therefore, there is a need to establish a "working temperature", also know as "effective temperature", for each de-icer where it can be optimally utilized. Effective temperature of a de-icing chemical is accepted to be the lowest temperature at which the de-icing chemical starts melting snow and ice within a 15 minute time window. Effective temperature is also where the addition of more chemical would not increase significantly the melting capacity of this chemical. Table 2.1 shows the Eutectic and effective temperatures for commonly used de-icing chemicals. The listed effective temperatures may vary with the other conditions, such as purity of material, and dilution rate [TAC,1999]. 
Table 2.1: De-icing Chemicals Temperature \& Concentration (Adapted from Transportation Association of Canada [TAC1999])

\begin{tabular}{|l|c|c|c|}
\hline \multicolumn{1}{|c|}{ Chemical } & $\begin{array}{c}\text { Eutectic } \\
\text { Temperature } \\
{ }^{\circ} \mathrm{C}\end{array}$ & $\begin{array}{c}\text { Eutectic } \\
\text { Concentration } \\
\%\end{array}$ & $\begin{array}{c}\text { Effective } \\
\text { Temperature } \\
{ }^{\circ} \mathrm{C}\end{array}$ \\
\hline Sodium Chloride $(\mathbf{N a C l})$ & -21 & 23.3 & -9 \\
\hline Calcium Chloride $(\mathbf{C a C l})$ & -51 & 29.8 & -32 \\
\hline Magnesium Chloride (MgCl) & -33 & 21.6 & -15 \\
\hline Potassium Acetate (KAc) & -60 & 49 & -26 \\
\hline Calcium Magnesium Acetate (CMA) & -27 & 32.5 & -6 \\
\hline
\end{tabular}

\subsection{Material Application Techniques}

De-icers can be applied in dry, pre-wetted or liquid format, depending on road temperatures, weather conditions and material availability. Dry salt is usually applied after snow has started to accumulate or ice has formed on the road. Pre-wetting is a technique whereby dry winter material is coated with a liquid before being applied on the road. Pre-wetting is used on rock salt and occasionally used on sand. Brine solutions (such as $\mathrm{NaCl}, \mathrm{CaCl}_{2}$, or $\mathrm{MgCl}_{2}$ ) are used as pre-wetting agents. Organic based solutions are also commercially available. Pre-wetting increases the retention of material on the road and shortens the de-icer reaction time. While direct liquid application is mostly used for anti-icing activities, however, it can also be used to de-ice black ice and frost on road surfaces, and in specialized configurations such as fixed automated bridge spray systems. 
Anti-icing is a proactive strategy for snow and ice control. It is the application of a chemical de-icer on the pavement before the start of, or at the onset of a winter weather event. Anti-icing is a preventative measure designed to inhibit snow and ice from bonding to the pavement surface. Anti-icing has been practiced in the past and became more viable with advancements in weather monitoring and road condition forecasting, advanced spreading equipment with computerized electronic controls, and more research and field experimentations [Minsk 1998]. Though less effective, anti-icing may also be performed with dry or pre-wetted de-icers. Successful deployment of anti-icing strategies must be accompanied by the necessary tools and components of a systematic decision making process. The concept of anti-icing can not be properly applied without road weather information and road condition forecasting systems. [FHWA 1996].

\subsection{Equipment for Winter Operations}

Equipment for snow and ice control varies from the simple handheld snow shovel to GPS-equipped automatic de-icing operations, and from the single-function unit to the multi-functional multi-season combination unit. Such equipment may include the capability to spread dry, pre-wet and liquid de-icers or a combination thereof. The most important feature of any material spreader is the rate-controller that controls the amount of material applied on the road. Knowledge and control of material application is critical in achieving a mandated level of service. Winter maintenance equipment also includes snow moving equipment such as: snow plows, snow blowers, graders, loaders, snow sweepers and snow melters. Other technologies are also employed such as Global 
Positioning Systems (GPS) and Geographic Information Systems (GIS), which are used in conjunction with data collection systems to monitor how equipment is performing, provide automatic vehicle location, material spreading rate and vehicle speed [Minsk, 1998].

\subsection{Winter Maintenance Policy and Level of Service}

A winter maintenance policy defines the minimum acceptable level of service for winter road maintenance. An established winter maintenance policy provides a medium for declaring the goals and objectives of the organization, such as commitments to environmental protection, operational efficiency and proper use of resources, and it serves to document the intent, capabilities and procedures of the snow and ice control program. Furthermore, a policy sets a platform for a common understanding of the agency's mandate and public's expectations. A written policy provides operations managers and staff with consistent methodology for delivering the same level of service. It provides guidelines and procedures on the use and allocation of resources such as materials, equipment and labour. A written policy establishes a legal basis for winter maintenance practices and affords a reasonable attestation of an agency's due diligence towards its winter maintenance mandate [AASHTO, 1999].

"Level of Service (LOS), in the context of roadway snow and ice control operations, is a set of operational guidelines and procedures that establish the timing, type and frequency of treatments" [NCHRP 526, 2004]. Road authorities define their LOS in a 
variety of ways; some are legislated by government, while others are based on a combination or subset of road classification systems, service priority, traffic volumes, speed limit, number of lanes, essential road links, availability of equipment, staff, material and public and political expectation [AASHTO, 1999]. A good example of legislated LOS is Ontario Regulation 239/02, Minimum Maintenance Standards for Municipal Highways, enacted under the 2001 Ontario Municipal Act. This legislation provides a minimum standard for maintenance on several road maintenance fronts, such as patrolling, potholes, shoulder drop-offs, cracks, debris, luminaries, signs, bridge deck spalls, roadway and sidewalk surface discontinuities, and snow accumulation and icy roadways [Ontario, 2002].

The Ontario regulation also provides a road classification system based on a simplified criterion of speed limit and traffic volumes as represented by the Average Annual Daily Traffic (AADT). Table 2.2 illustrates this classification. The regulation also sets the type of treatment as per road classification, where it sets a depth of allowable snow accumulation at which the municipality will start to "deploy snow-clearing resources as soon as practicable" and have a set amount of time to clear the road to this accumulation depth or less, as well as define the minimum width of road that needs to be cleared. There is also a similar threshold for icy roads. However, it is noted that road classification 6 is not listed within the level of service requirements and it is assumed that there is no set level of service for this type of low-volume low-speed roads [Ontario, 2002]. 
Table 2.2: Ontario's Classification of Highways

(Reproduced from Ontario Reg. 239/02 [Ontario, 2002])

\begin{tabular}{|c|c|c|c|c|c|c|c|}
\hline $\begin{array}{c}\text { AADT } \\
\text { (number of motor } \\
\text { vehicles) }\end{array}$ & \multicolumn{6}{|c|}{ Posted or Statutory Speed Limit (kilometres per hour) } \\
\cline { 2 - 8 } & $\mathbf{9 1 - 1 0 0}$ & $\mathbf{8 1}-\mathbf{9 0}$ & $\mathbf{7 1 - 8 0}$ & $\mathbf{6 1}-\mathbf{7 0}$ & $\mathbf{5 1}-\mathbf{6 0}$ & $\mathbf{4 1}-\mathbf{5 0}$ & $\mathbf{1 - 4 0}$ \\
\hline 15,000 or more & 1 & 1 & 1 & 2 & 2 & 2 & 2 \\
\hline $12,000-14,999$ & 1 & 1 & 1 & 2 & 2 & 3 & 3 \\
\hline $10,000-11,999$ & 1 & 1 & 2 & 2 & 3 & 3 & 3 \\
\hline $8,000-9,999$ & 1 & 1 & 2 & 3 & 3 & 3 & 3 \\
\hline $6,000-7,999$ & 1 & 2 & 2 & 3 & 3 & 3 & 3 \\
\hline $5,000-5,999$ & 1 & 2 & 2 & 3 & 3 & 3 & 3 \\
\hline $4,000-4,999$ & 1 & 2 & 3 & 3 & 3 & 3 & 4 \\
\hline $3,000-3,999$ & 1 & 2 & 3 & 3 & 3 & 4 & 4 \\
\hline $2,000-2,999$ & 1 & 2 & 3 & 3 & 4 & 4 & 4 \\
\hline $1,000-1,999$ & 1 & 3 & 3 & 3 & 4 & 4 & 5 \\
\hline $500-999$ & 1 & 3 & 4 & 4 & 4 & 4 & 5 \\
\hline $200-499$ & 1 & 3 & 4 & 4 & 5 & 5 & 5 \\
\hline $50-199$ & 1 & 3 & 4 & 5 & 5 & 5 & 5 \\
\hline $0-49$ & 1 & 3 & 6 & 6 & 6 & 6 & 6 \\
\hline
\end{tabular}

Table 2.3: Snow Accumulation Triggers

(Source: Government of Ontario, O. Reg. 239/02, [Ontario, 2002] )

\begin{tabular}{|c|c|c|}
\hline Class of Highway & Depth & Time \\
\hline 1 & $2.5 \mathrm{~cm}$ & 4 hours \\
\hline 2 & $5 \mathrm{~cm}$ & 6 hours \\
\hline 3 & $8 \mathrm{~cm}$ & 12 hours \\
\hline 4 & $8 \mathrm{~cm}$ & 16 hours \\
\hline 5 & $10 \mathrm{~cm}$ & 24 hours \\
\hline
\end{tabular}

Table 2.4: Icy Roads Triggers

(Source: Government of Ontario, O. Reg. 239/02, [Ontario, 2002])

\begin{tabular}{|c|c|}
\hline Class of Highway & Time \\
\hline 1 & 3 hours \\
\hline 2 & 4 hours \\
\hline 3 & 8 hours \\
\hline 4 & 12 hours \\
\hline 5 & 16 hours \\
\hline
\end{tabular}


The City of Ottawa provides another good example illustrating the link between road classification and level of service. The City's website states the winter maintenance objective "is to keep streets safe and passable by reducing the hazards caused by snow and ice accumulation", while providing a table showing their targeted level of service titled Maintenance Quality Standards [Ottawa, 2005]. The City's quality standard is based on a road classification system specially designed for maintenance, which differs from the road classification system established under City bylaws. The standard indicates road maintenance class and road type, a deployment trigger and a time limit to complete or repeat operational activities until the "Treatment Standard" is reached. Table 2.5 describes these maintenance quality standards.

Table 2.5: City of Ottawa Maintenance Quality Standards - Roads (Source City of Ottawa, www Ottawa ca and [Ottawa, 2005])

\begin{tabular}{|c|c|c|c|c|c|c|c|}
\hline \multirow{2}{*}{\multicolumn{2}{|c|}{ nce }} & \multirow{2}{*}{ 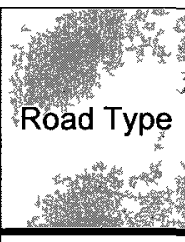 } & \multirow{2}{*}{$\begin{array}{l}\text { Mınımum } \\
\text { Depth of Snow } \\
\text { Accumulation } \\
\text { for Deployment } \\
\text { of Resources } \\
\text { o }\end{array}$} & \multirow{2}{*}{$\begin{array}{l}\text { Time to Clear Snow } \\
\text { Accumulation From } \\
\text { the End of Snow } \\
\text { Accumulation or } \\
\text { Time to Treat Icy } \\
\text { Conditions }\end{array}$} & \multicolumn{3}{|c|}{ Treatment standard } \\
\hline & & & & & Bare & Cêntre & Snow \\
\hline \multirow{2}{*}{1} & A & \multirow{2}{*}{$\begin{array}{l}\text { High Priority } \\
\text { Roads }\end{array}$} & \multirow{6}{*}{$\begin{array}{c}\text { As accumulation } \\
\text { begins }\end{array}$} & \multirow{2}{*}{2 hours } & $x$ & & \\
\hline & $B$ & & & & $x$ & & \\
\hline \multirow{2}{*}{2} & $A$ & \multirow{2}{*}{ Most Arterials } & & \multirow{2}{*}{3 hours } & $x$ & & \\
\hline & $B$ & & & & $x$ & & \\
\hline \multirow[t]{2}{*}{3} & A & \multirow{2}{*}{$\begin{array}{l}\text { Most Major } \\
\text { Collectors }\end{array}$} & & \multirow{2}{*}{4 hours } & $x$ & & \\
\hline & $B$ & & & & $x$ & & \\
\hline \multirow{3}{*}{4} & A & \multirow{3}{*}{$\begin{array}{l}\text { Most Minor } \\
\text { Collectors }\end{array}$} & \multirow{3}{*}{$5 \mathrm{~cm}$} & \multirow{3}{*}{6 hours } & $x$ & & \\
\hline & $B$ & & & & & $x$ & \\
\hline & C & & & & & & $x$ \\
\hline \multirow{2}{*}{5} & $A, C$ & \multirow{2}{*}{$\begin{array}{l}\text { Residential } \\
\text { Roads and } \\
\text { Lanes }\end{array}$} & $7 \mathrm{~cm}$ & 10 hours & & & $x$ \\
\hline & B & & $10 \mathrm{~cm}$ & 16 hours & & & $x$ \\
\hline
\end{tabular}




\subsection{The Human Side of Decision Making}

The human behavioural aspects of decision making should to be considered for its influence on the decision making process, and to better understand how people make decisions. A 'decision' is defined as a "choice made between alternative courses of action in a situation of uncertainty" while 'decision making' is defined to be: "the thought process of selecting a logical choice from among the available options" [Business 2010]. Decisions are made up of three main elements: belief, facts and data. One must acknowledge that data alone is not useful, it must be analyzed and processed and it needs to be reliable. This is the essence of a good decision [McDermott, 2008].

There are many types of decision-making. Types vary by human nature, ambient environment or decision subjects. However, common types of decision making include; the 'rational', 'intuitive' and 'recognition-primed' types. Rational decision making is the most common as it is easy to understand and quantify. It is logical, sequential and emphasizes the importance of working out the most suitable course of action based on measurable variables. Intuitive decision making is a process where no reason or logic is used and mainly relies on inner feelings, tacit knowledge, intuition and ESP (Extrasensory Perception). This type of decision making is sometimes perceived to be inconsistent and unreliable. Decisions made using this method are perceived as unlikely coincidences, lucky guesses, or some kind of spurious magic. However, intuitive decision making is not necessarily the complete opposite of rational decision making; rather it is seen as a different and sometimes faster type of decision-making. Seemingly, there is 
logic and innate process to this type of decision making, though not easily visible behind the intuition. A third type of decision-making is known as 'recognition-primed'. In this type, the decision maker mentally rehearses the process, reviews and analyses alternatives and outcomes, and then selects a course of action based on the belief that it will work and yield the desired outcome. However, should the first scenario not mentally work, then the decision maker chooses another option and repeats the mental process until the best decision has been selected [McDermott, 2008].

Different approaches and styles are followed when making decisions, with breadth and diversity as diverse as the human emotions. Styles can be analytical or conceptual; there is also the impulsive, where a decision is made with little or no consideration to the outcome. Close to that, is the fatalistic or resigned style where decisions are made with an attitude of apathy. The procrastinating style is where the decider delays the making of the decision for one reason or another, while the 'play-itsafe' style prefers selecting the choice with the least amount of risk. Some people have a style of agony where they worry overwhelmingly over a particular decision, and others would be compliant or dependant: going along or allowing others to make the decision. There are also the proactive or the flexible styles where the decider uses more than one, or a mix of different style categories. There are many degraders that can damage a decision or hinder the process to the point where the decision is not made or the wrong decision is made. Decision degraders may include delays, mistakes, traps and fallacies [McDermott, 2008]. 


\section{CHAPTER 3 DECISION SUPPORT FOR WINTER OPERATIONS}

The discussions in this chapter are based on the author's experience as a long time municipal engineer within public works departments of major municipalities. The discussions are the author's understandings of the decision support tools within winter maintenance operations, and a complement to the literature review in chapter 2.

\subsection{Operational Routes for Decision Support}

Maintenance activities are usually delivered through repetitive, cyclic activities based on a preset frequency. This facilitates planning work ahead of time in the format of cyclic routes (beats). While winter operations' planning is an extensive discussion subject, the focus in this section is on planning (creating) operational routes for activities such as plowing, salting, sanding, liquid application or snow removal.

At a simple level, route creation is the amount of distance, within a time limit, a maintenance vehicle can travel while performing an activity before it needs to reload, refuel, or runs out of time. For example, in the case of a material spreader: Assuming an application rate of $130 \mathrm{~kg} / 2-\mathrm{lane}-\mathrm{km}$, and a spreader truck with (10) metric tons of capacity. The unit will be able to cover $76.92 \mathrm{~km}(10,000 \mathrm{~kg} \div 130 \mathrm{~kg} / 2-\mathrm{lane}-\mathrm{km}=76.92$ $\mathrm{km}$ ), and assuming a $32 \mathrm{~km} / \mathrm{h}$ average route speed, this unit should complete the proposed route in approximately 2.4 hours. 
The above simple calculations indicate that an operation route for salt spreading could cover 76 kilometres of a 2-lane roadway and be completed in 2.4 hours, or cover approximately 38 kilometres of a 4-lane roadway in the same amount of time. Route creation is a decision support tool that allows for verification of field results of operational activities such as actual application rate, total amount of salt spread, and average driving speed.

Operation routes can be created with a complex set of variables to create optimal routes for operational activities. Route creation variables may include; road classification, area topography, traffic volumes, road width, turn and directional restrictions (one way, no left turns), traffic restriction and peak times and parking prohibitions. On the operational side, factors include jurisdictional limits, operational polices and procedures, level of service, cycle times, material supply depots, fuelling stations, material application rate, maintenance vehicle type, operating speed, number, storage location and capacity, and the sequence of maintenance activities.

\subsection{Decisions and Equipment}

Different types of equipment can influence decisions made for winter operations. A decision made with single unit salt spreaders or plow units will vary from one made with combination units (plow and spreader units). This will affect the process flow of the operation, and will demand different procedures be established for making a decision based on, or largely influenced by, what equipment is available in the agency's fleet. 
For example, if a road authority had plow-only and spreader-only units in their fleet, they would then develop "plow-only" routes and "spreader-only" operational routes. Such routes may not necessarily be the same, due to the different characteristics of the equipment. The option may be to have a set of plows deployed when snow accumulation reaches a certain depth, while the spreaders are deployed when salting alone is sufficient. Using the same logic, the "plow only" routes will be focused on opening major roads and intersections, while the spreaders will focus on salting hills, curves and bus routes. There is also the possibility of teaming up the fleet with a plow and a spreader on each route; however, plow units deliver their function at a different rate of speed than a spreader unit with varying road coverage and production rate. A plow can plow/remove snow from one lane width at a time, while a spreader can be configured to spread over several lanes at the same time and at a higher speed. The decision for using a multifunctional piece of equipment, or combination unit, requires a different thought process than single function units. The deployment frequency for a combo unit is different from a single-function unit, therefore operational procedures will differ and subsequently the decision making tree is affected. This illustrates the different decisions that need to be made directly relating to equipment. The number of possible decisions will increase when considering locations of associated facilities such as work depots, material storage domes, and snow disposal facilities. 


\subsection{Operational Information for Decision Making}

Operational information refers to detailed knowledge recorded about the winter maintenance activities performed during the operation. Such information includes in part route length, material type and application rate, time of completion. This information has always existed and has been recorded on paper forms and daily reports. However, with the computerization of maintenance vehicles, this information and much more are recorded electronically and are made available. For example, it is common practice in the industry that salt spreader units are equipped with an electronic spreader controller. The controller allows for precise control of material spreading, and at the same time is able to record events such as start and end times, material types, quantity and material application rate, and if equipped with a Global Positioning System (GPS), location tracking. Furthermore, through advanced wireless communication, there exists the ability to place this information into the hands of decision makers while the operation is in live progress, making it a valuable decision support tool.

Automatic Vehicle Location (AVL) is a commonly used term to describe the automatic tracking of the geographic location of a moving vehicle using coordinates of the Global Positioning System (GPS). AVL is used as a stand-alone system or as part of the much larger data collection system. Operational information can be used within the framework of decision making, and whether the information is collected manually using pen and paper, or collected using the new sophisticated electronic system, it could be an integral component of decision support for winter maintenance. 


\subsection{The Snow Desk}

A command centre for winter maintenance operations is common within large road authorities, and for major storms, such command centres are referred to as snow desks. The snow desk serves to centralize decision making for winter operations. Information from other agencies will be directed to the command centre. By storing all the information at a central location, managers can perform essential data analysis to assess and modify operational decisions.

A winter maintenance command center does not have to be the classical, physical office where at least one person is available at all times to monitor and respond to the operation. The command and control concept can be achieved by having a virtual command and control center providing access to the same information that is housed in a central location. By utilizing new networking technologies, such as the Internet, Local Area Networks (LAN), and Wide Area Networks (WAN), cell phones, video conferencing, wireless email, instant text and video messaging, road authorities can establish a virtual command center that is accessible by remote means. It allows for all decision makers to access the same information and interact with each other, whether they are in a command room or at a home computer, or anywhere in between via a mobile interface. 


\subsection{Automated Decision Support Systems}

Several systems are emerging in an attempt to automate the decision making process for winter maintenance. The Ministry of Transportation of Ontario (MTO) has developed the De-icing Anti-icing Response Treatment (DART) database. DART is designed to be fed with weather and operational data and in turn it will provide recommendations on a treatment plan based on pre-set criteria for snow and ice control material application rates. The Federal Highway Administration (FHWA) Office of Transportation Operations initiated a program in 2001 for the development of a winter road Maintenance Decision Support System (MDSS). The system would integrate data from road weather information systems, weather forecasting, road operations operational procedural policies, and represent them in a simplified manner for decision makers, as well as provide recommendation to operations managers on possible treatment options and proposed courses of action for snow and ice control. MDSS has been in various prototype stages for the past several years with several challenges yet to be addressed.

Another example of automating some decisions for winter operations is the development of a GPS-controlled material spreader. The concept revolves around planning a material spreading route, where the actions of the operator, such as start of spreading, change in spreading width, liquid application start and end, and material rate change are recorded electronically with the appropriate GPS stamp. The recording is then saved into the spreader controller, and when activated, the driver need not operate the spreader; it will recognize its GPS location and will start reproducing all actions based on 
where they were recorded in relation to the GPS coordinates. This system allows the driver to focus on driving, while the vehicle's automated features operate the rest of the unit. EpoSat(C), by Epoke of Denmark, is such a system and it has had some limited success in Canada.

\subsection{Winter Maintenance Management Systems}

A Winter Maintenance Management System (WMMS) combines information and procedures needed by operators and operation managers in a single decision making tool. Once the decision is made to mobilize equipment and staff for the operation, the system then provides support, allowing operators and supervisors to manage all aspects of the operation and associated activities.

A good management system would have the ability to integrate the various types of equipment data outputs into a unified database, allowing for a consistent presentation of information for decision making, regardless of the source generating data, ranging from manual input to the fully automated live data collection schemes. A winter maintenance management system built with the proper components can be the ultimate decision support system. Such a system would be utilized before, during, and after each winter maintenance event, and would allow for flexibility to adapt to changing demands for winter road maintenance. A good example is the Danish Road Authority's model for winter maintenance management, which in collaboration with local municipalities in Denmark developed a winter maintenance management system (Vinterman). The system 
is used by road authorities and contractors, to manage winter maintenance operations. The Danish system was designed to be operated by local municipalities, where RWIS information is obtained from local stations, in conjunction with the local practices and established levels of service. Operational decisions are made locally for local roads. However, the local road authority could choose to share their system's data with the national road authority. The system then sends relevant local data on road status from spreaders, plows, and contractors to the national road authority, where the data is stored and maintained in a database that is synchronized nationally. This information is compiled by the national road authority, and displayed on a website for road users nationwide. 


\section{CHAPTER 4}

\section{DECISION MAKING FRAMEWORK}

Decision making is not an exact science; it is rather an art of balance and judgment. There is no one right answer or fixed course of action all the time, rather there is the best answer or the most appropriate course of action, based on the circumstances and the given input variables at a point in time. This is the nature of winter maintenance decision making, because the input variables change every time the weather changes. So how can one make a decision the same way every time with these varying inputs? This is where a framework may provide value, and allow for a consistent approach to make decisions for winter maintenance operation to provide safe and passable roads, and safeguarding human life and property.

\subsection{Decision Points}

Decision points within the winter maintenance operation need to be defined in terms of when they occur and for what key element of the operations. To illustrate this issue, take the example of pavement temperature as a key decision factor for when to apply salt and sand for snow and ice control. By knowing that salt starts to depress the freezing point at just below zero degrees, it makes a pavement temperature of zero a decision point at which the decision to apply salt would be the proper course of action. However, should the temperature be less than the working temperature of salt $\left(-9^{\circ} \mathrm{C}\right)$, then a decision has to be made at that point in time when pavement temperature is less 
than $-9^{\circ}$, to change that applied material to a salt/sand mix. Should the temperature be even lower, then another decision point emerges to stop salting or change to a more effective chemical suitable for the new situation. Figure 4.6 shows a flowchart illustrating decision points. However, in a multifaceted operation, decision points may not be so simple and be dependant on single factor. The more likely scenario is that there are several key factors interacting to determine decision points.

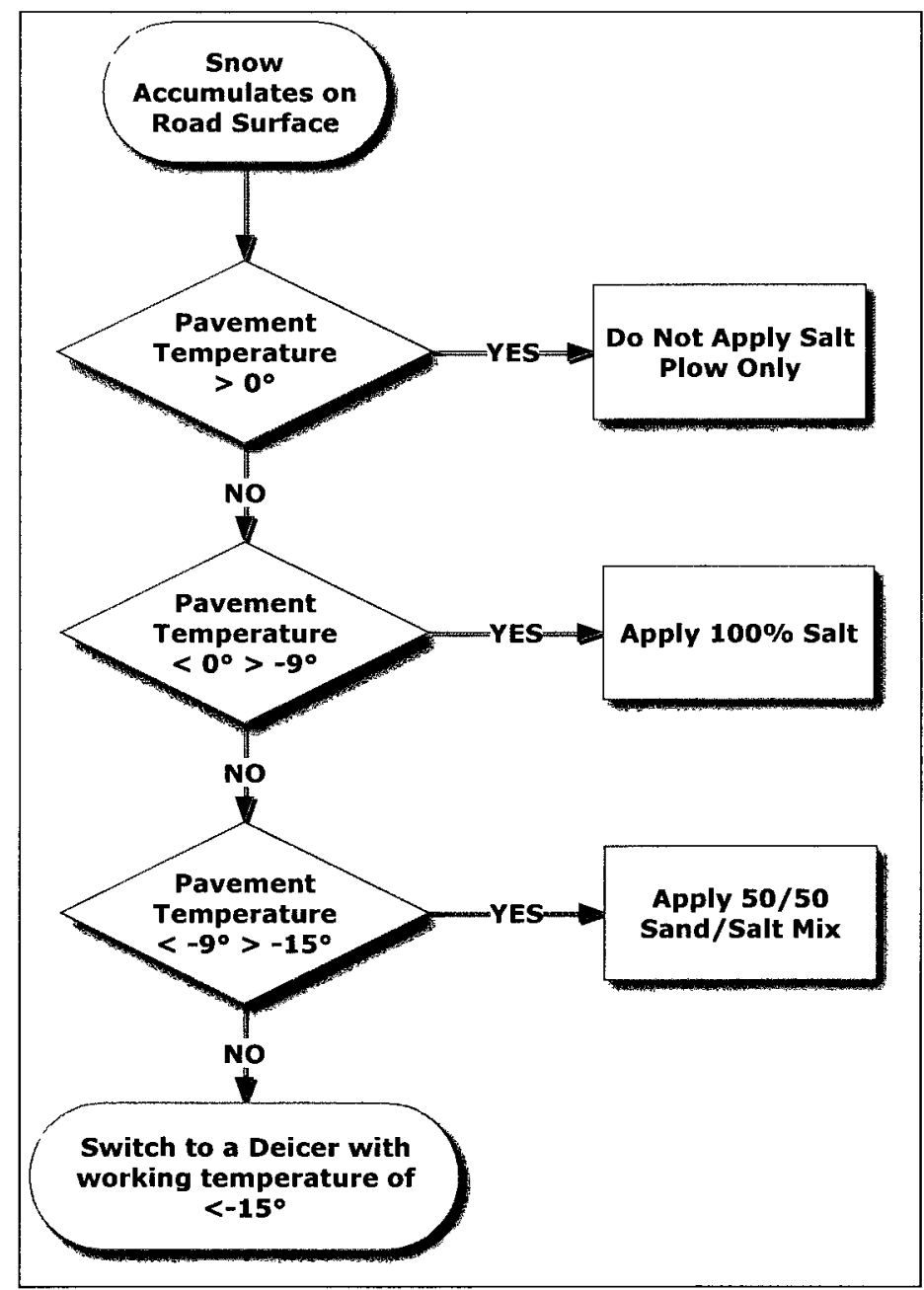

Figure 4.6: Decision Points for Pavement Temperature 


\subsection{Decision Making Hierarchy}

The organizational structure within the winter maintenance road authority is a major factor in building frameworks for decision-making. The size of an organization will play a significant role in the shape of its organizational structure, and subsequently the chain of command for any decision making. A small town would have a smaller hierarchy, while a large municipal or provincial road authority would have multi-level and branching hierarchies which may complicate the process. This will mandate that more rules and guidelines be instituted for how and who can make a decision.

In order to have a systematic framework for making decisions, one of the first steps for a road authority is to establish a decision making hierarchy, where decision makers within the organization are designated at their appropriate level, and their area of responsibility is outlined, in terms of who can make a decision for each specific activity. A Decision-making matrix would be established, based on the particular winter operations activities undertaken by the road authority, as well as the number and available levels of decision makers. The matrix may be configured in a way to incorporate which operation can take precedence over another. For example, a city where the downtown area does not have on-road snow storage, de-icing (salting) will take precedence over plowing, and should plowing become necessary, it would have to be initiated in tandem with snow removal operations. When operational activities have been assigned a priority level, then a decision-making level is assigned, thus designating which level of management can make a decision on initiating the specific operation. A typical 
outline of an organizational structure and operational decision-making levels is shown in concept in Figure 4.7.

\section{Decision-Making Hierarchy}

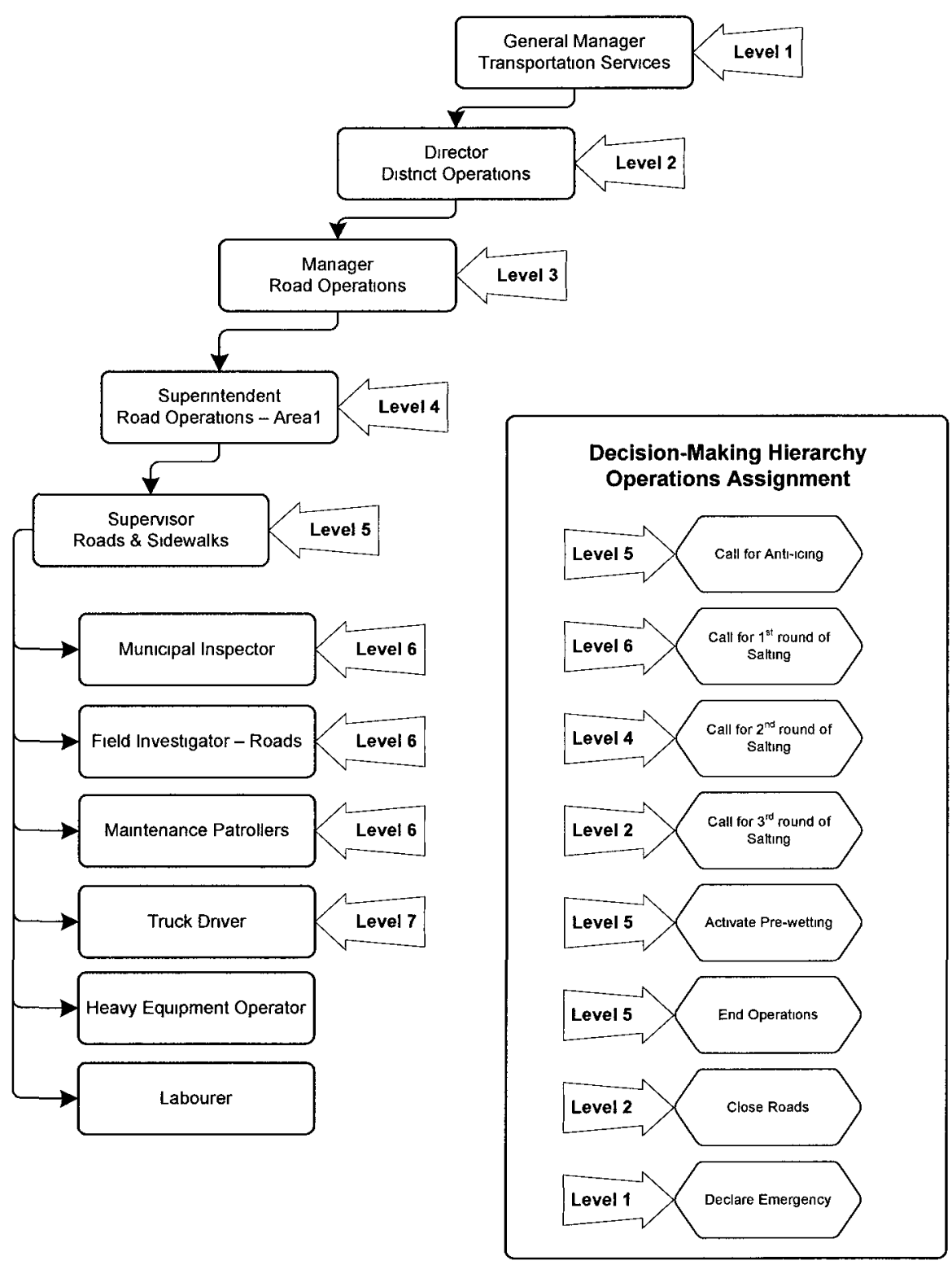

Figure 4.7: Typical Decision-Making Hierarchy 


\subsection{Decision Making Process}

Once a decision-making matrix is in place within an organization, decisions can be made in stages as they are called for by the proposed framework. The first stage is a pre-storm stage, which is usually initiated by mid-October for most Canadian cities. In this stage, preparations for winter operation would have begun with clear milestones to ensure readiness at the onset of the first snow event of the season. At this stage, decision makers will monitor available support systems in order to make the appropriate decisions at the right time.

The flow chart shown in Figure 4.8 shows a typical pre-storm decision making process. The operation manager monitors all the available inputs, such as information from the road patrollers, field observations by staff, reading by the road weather information system, weather forecast, road condition forecast, and pavement temperatures. Once the determination has been made of an impending weather event, the decision is based on the type of the anticipated storm. Storm type will influence the decision of whether or not to mobilize winter maintenance services. Should mobilization be required this in turn will determine the type of operation to be initiated first, (e.g. salting or plowing). At this point, the decision-making hierarchy would be applied to ensure that the proper level of response has been authorized by the appropriate level of management. This also ensures that communication channels are utilized, as well as provide the platform for the next set of decision choices. At the end of this cycle, the selected mobilization plan will be implemented. 


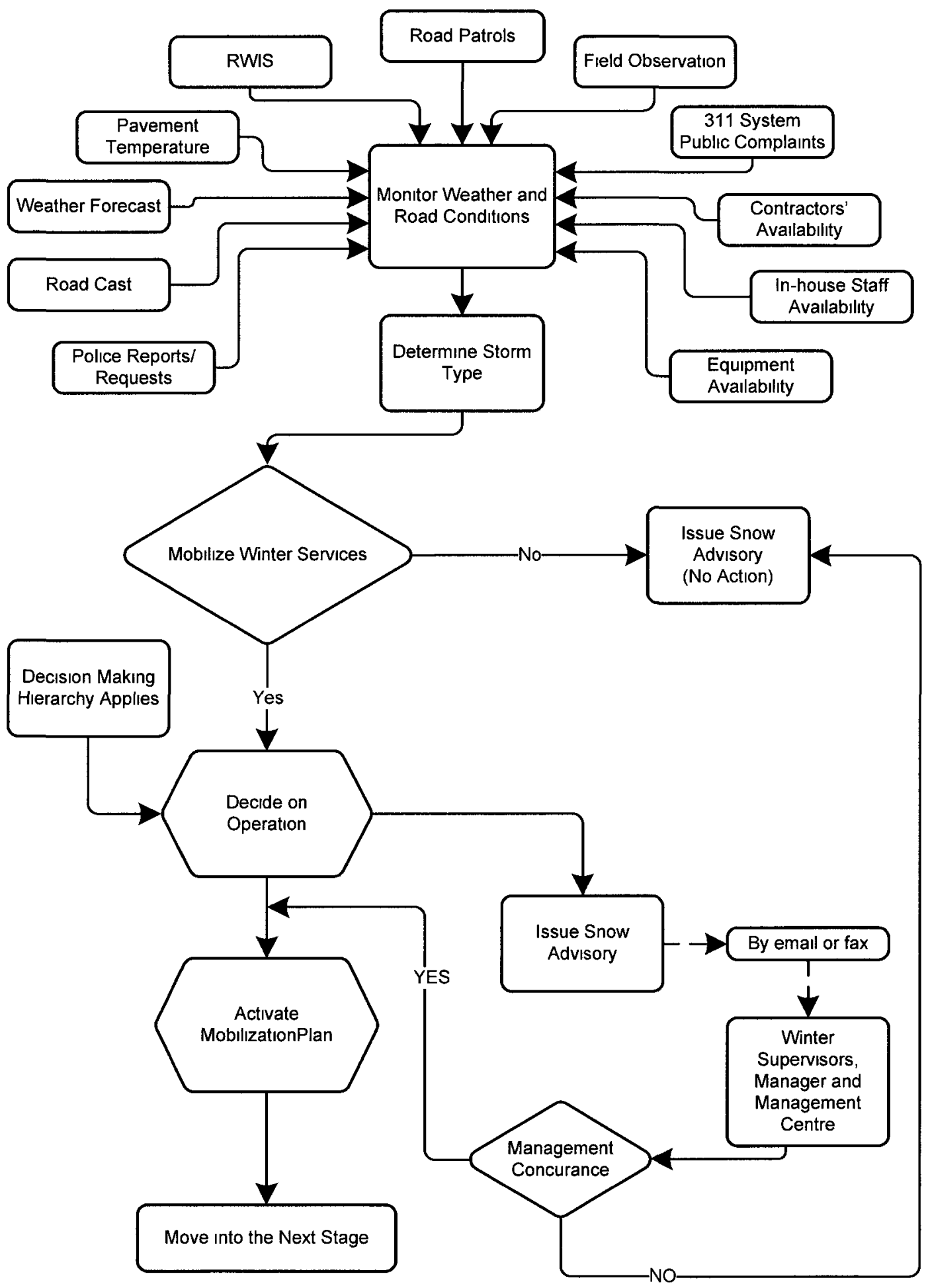

Figure 4.8: Typical Pre-Storm Decision Making Process 
Once a decision has been made to activate a mobilization plan the operation moves into the next stage of the framework. A mobilization plan may consist of one activity based on a simple trigger, such as 'apply salt at $130 \mathrm{~kg} / \mathrm{lane}-\mathrm{km}$ at the start of the snow event', or it could be more complex with multiple activities. No matter how complex a plan is, it must be outlined in advance of the actual operation.

The flow chart shown in Figure 4.9 illustrates actions to be taken upon the activation of the mobilization plan. Figure 4.9 is a continuation of the process illustrated in Figure 4.8. In this example, the decision was made to initiate an anti-icing activity. 


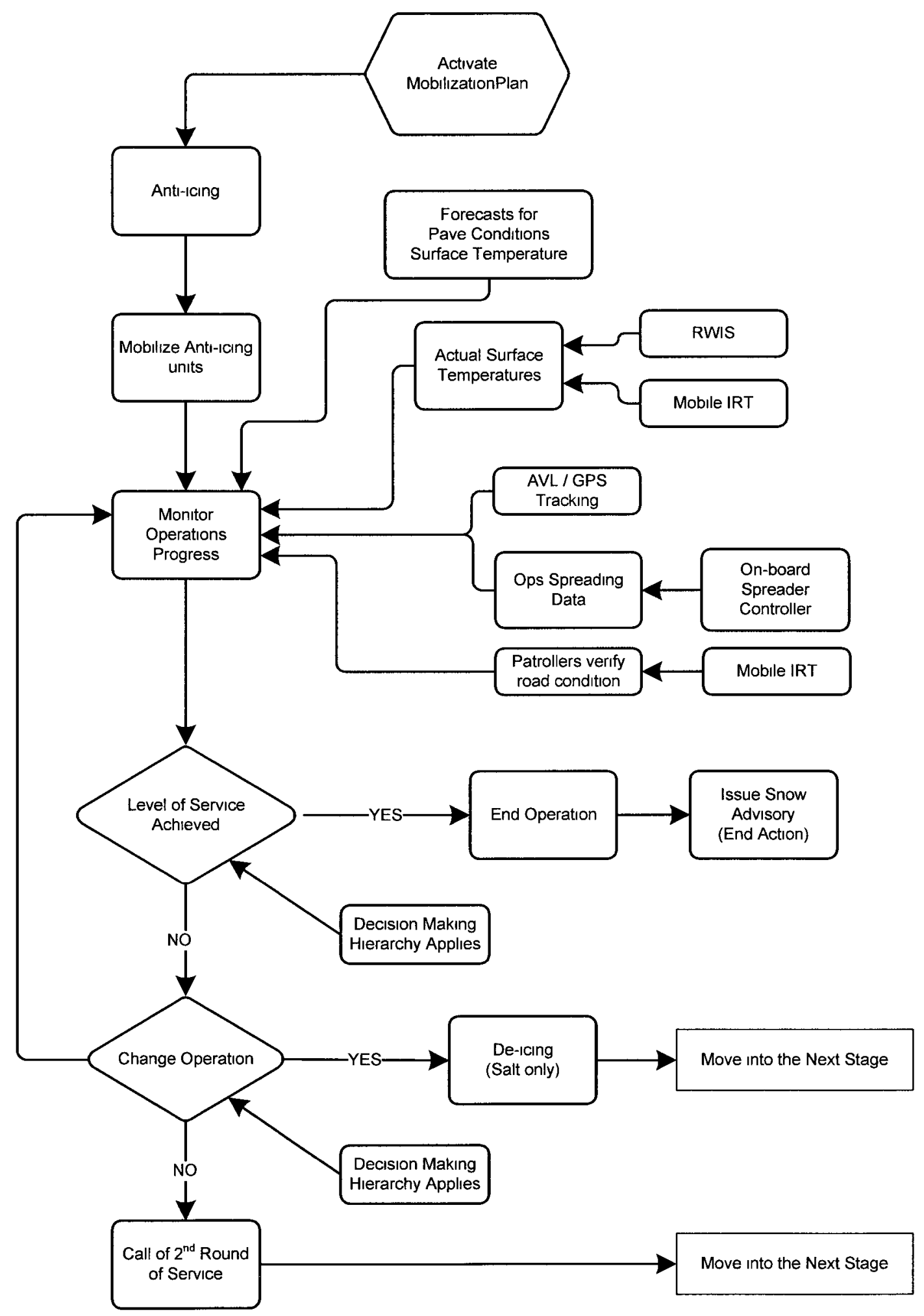

Figure 4.9: Typical in-Storm Decision Making Process 


\section{CHAPTER 5}

\section{CASE STUDY AND ANALYSIS}

The City of Toronto has been selected for this case study. The decision-making process for winter maintenance operations for the City has gone through several transformations since the creation of the new City of Toronto, after the amalgamation of seven area municipalities, as of January of 1998. Toronto is Canada's largest city with a population of approximately three million people. The Greater Toronto Area is estimated to have a population of approximately six million residents. The focus of this case study is the decision-making within Road Operations of the Transportation Services Division for the delivery of winter maintenance operation. The research will use data from the city's road operations section, and weather information from Environment Canada weather archives, and work to associate winter road operational data with recorded weather information, and will examine the relationship between levels of effort as they relate to decisions made to mobilize winter vehicles and winter related collisions for six winter seasons from 2004-2005 to 2009-2010. The focus of the study is on salting and anti-icing activities.

\subsection{Transportation Services Division - Background}

The City of Toronto Transportation Services Division is responsible for maintaining the City's roads infrastructure. The division is responsible for $5,600 \mathrm{~km}$ of roads, $7,945 \mathrm{~km}$ of sidewalks, 442 bridges, 504 pedestrian crosswalks, 2,184 traffic signals, 4,100 bus shelters, and over one million street signs. The road network also 
includes $112 \mathrm{~km}$ of bike lanes, $168 \mathrm{~km}$ of bike trails, and $138 \mathrm{~km}$ of bike routes. This is in addition to 25,000 pieces of street furniture. The Division carries a multitude of activities in order to continually maintain liveable streets for all Toronto residents. Such activities include minor and major road and sidewalk maintenance, street cleaning, snow clearing and road salting, traffic signs and pavement markings, traffic signals and traffic safety, red light camera operations, construction planning and policies, pedestrian and cycling programs, installing street furniture, developing public spaces, and issuing permits for onstreet parking, construction, and street events [City of Toronto]. Transportation Services Division is divided into 4 Districts, each headed by a Director of Operations, and a number of managers reporting to each Director. Each manager heads an operational portfolio such as Road Operations, Traffic Management, Surface Maintenance and Right of Way Management. The focus in this case study will be on winter road operations.

\subsection{Winter Road Operations}

The City of Toronto winter road maintenance operation operates with a budget of $\$ 80$ million. Transportation Services delivers winter maintenance services using 571 road plow machines, 322 sidewalk plows and 203 dedicated salt trucks. The nearly 1100 unit fleet is operated by 536 City Staff and 1,068 Contractors' staff. The operation uses an average of 138,500 tonnes of salt per year, worth approximately $\$ 7.5$ million (as budgeted in 2009) spread over 40 to 50 de-icing events. The historic 30 -year average of snowfall for Toronto is an average annual of $133 \mathrm{~cm}$ [City of Toronto]. The City of Toronto employs specialized weather forecasting services, a limited scale road weather 
information system, and a GPS-enabled automatic vehicle location system. They also use pre-wetting capable salt spreaders, and a limited number of liquid anti-icing units. This is accompanied by a series of policies and operational guidelines such as the Salt Management Plan and salting and plowing charts.

The City of Toronto classifies winter storms in four major categories based on the forecasted snow accumulation. The four storm types are: 1) Storm Type 1: Snow accumulation up to 5 centimetres, 2) Storm Type 2: Snow accumulation from 5 up to 15 centimetres, 3) Storm Type 3: Snow accumulation from 15 to 25 centimetres, and 4) Storm Type 4: Snow accumulation over 25 centimetres. Each storm type requires a predetermined level of management authorization, and a specified level of service response. For the purpose of winter maintenance, the City classifies roads into several categories; each road classification is assigned a Level of Service, largely based on city policies and provincial minimum maintenance standards. For example, Expressways and Arterials have a "Bare Pavement" level of service, while Collector roads have a level of service of “Centre Bare Pavement”. Table 5.6, Toronto's Road Classification Salting Chart, shows road classifications and their associated levels of service [Toronto, 2009]. 
Table 5.6: Toronto's Road Classification - Salting Chart

(Adapted from City of Toronto Salt Management Plan 2009)

\begin{tabular}{|c|c|c|c|c|c|}
\hline $\begin{array}{c}\text { Road } \\
\text { Classification }\end{array}$ & Typical & $\begin{array}{c}\text { Winter Service } \\
\text { Levels }\end{array}$ & De-icer & $\begin{array}{c}\text { Application } \\
\text { Rate } \\
\text { kg/lane-km }\end{array}$ & $\begin{array}{c}\text { Time Frame To } \\
\text { Complete De-icer } \\
\text { Operations }\end{array}$ \\
\hline Expressways & $\begin{array}{l}\text { Don Valley } \\
\text { Parkway }\end{array}$ & Bare Pavement & $\begin{array}{l}100 \% \\
\text { Rock Salt }\end{array}$ & $70 / 140 / 180$ & $\begin{array}{l}\text { Up to } 2.5 \mathrm{~cm} \text { of snow } \\
1-2 \mathrm{hrs}\end{array}$ \\
\hline $\begin{array}{l}\text { Arterıals } \\
\text { (mınor / major) }\end{array}$ & $\begin{array}{l}\text { Yonge Street, } \\
\text { Sheppard Ave. }\end{array}$ & Bare Pavement & $\begin{array}{l}100 \% \\
\text { Rock Salt }\end{array}$ & $70 / 140 / 180$ & $\begin{array}{l}\text { Up to } 5 \mathrm{~cm} \text { of snow } \& \\
\text { continuing } \\
2-4 \mathrm{hrs}\end{array}$ \\
\hline Collectors & $\begin{array}{l}\text { Main Streets } \\
\text { through sub- } \\
\text { division }\end{array}$ & $\begin{array}{l}\text { Centre Bare } \\
\text { Pavement }\end{array}$ & $\begin{array}{l}100 \% \\
\text { Rock Salt }\end{array}$ & $70 / 140 / 180$ & $\begin{array}{l}\text { Up to } 8 \mathrm{~cm} \text { of snow } \& \\
\text { stopped } \\
4-6 \mathrm{hrs}\end{array}$ \\
\hline Locals & Residentıal Streets & $\begin{array}{l}\text { Safe and Passable } \\
\text { Pavement }\end{array}$ & $\begin{array}{l}100 \% \\
\text { Rock Salt }\end{array}$ & $70 / 90$ & $\begin{array}{l}\text { Up to } 8 \mathrm{~cm} \text { of snow }+ \\
\text { stopped } \\
8-12 \mathrm{hrs}\end{array}$ \\
\hline Laneways & & $\begin{array}{l}\text { Safe and Passable } \\
\text { Pavement }\end{array}$ & $\begin{array}{l}100 \% \\
\text { Rock Salt }\end{array}$ & 180 & $24 \mathrm{hrs}$ \\
\hline
\end{tabular}

The decision-making hierarchy, within the Transportation Division, is aligned with the organizational structure; however, the hierarchy is reversed for winter operations' decision making. Frontline staff is tasked with making the first decision under preauthorized criteria. As the storm and road conditions escalate, the need to escalate the operation requires the next level up on the organizational chart to make a decision. In this configuration, the front line staff can be considered level zero, their supervisors would be level one and the managers are level two followed by the winter director at level three. The winter director would have the responsibility of coordinating citywide responses to winter events, as well as resolving conflicts between the winter district managers when opinions differ on coordination issues between these districts. Other senior management staff are kept informed throughout the process to ensure consistency and continuity of the decision making process. Figure 5.10 has been reproduced from an existing flow chart for the Toronto-East York District, illustrating the district's winter mobilization procedure. It 
should be noted that the mobilization procedure further separates type 2 stores into two subcategories, from $5 \mathrm{~cm}$ to $8 \mathrm{~cm}$ and from $8 \mathrm{~cm}$ to $15 \mathrm{~cm}$, thus setting the $8 \mathrm{~cm}$ mark as the threshold for initiating snow plowing activities.

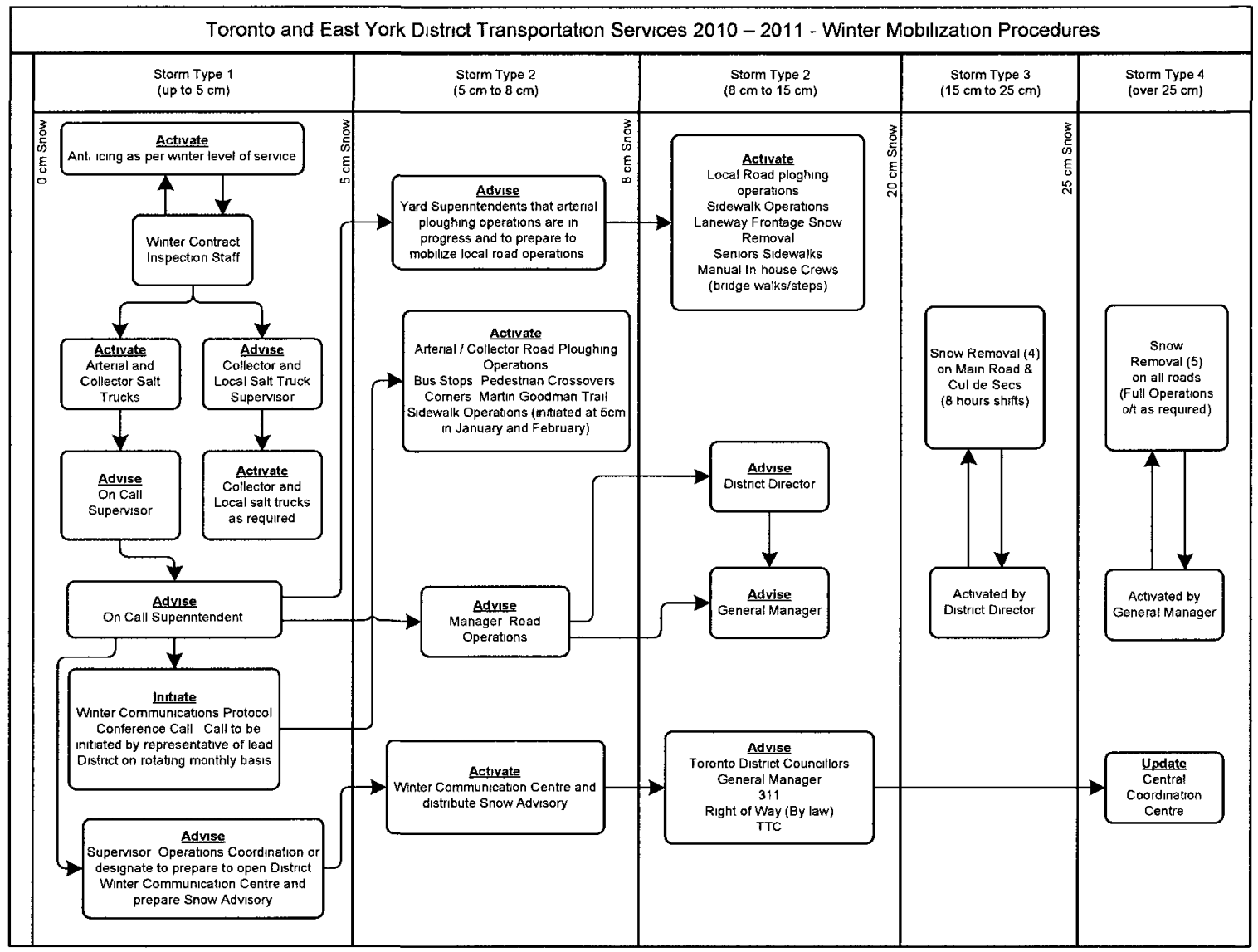

Figure 5.10: Winter Mobilization Procedure

(Source: City of Toronto, reproduced)

\subsection{Weather Data for Toronto}

Weather data for the Toronto area was obtained from the National Climate Data and Information Archive [Environment Canada, 2010], provided by the Canadian Ministry of the Environment, Environment Canada. The information extracted was for 
the Environment Canada weather station at the Toronto Lester B. Pearson International Airport, which is positioned at a Latitude: $43^{\circ} 40^{\prime} 38.000^{\prime \prime} \mathrm{N}$, Longitude: $79^{\circ} 37^{\prime} 50.000^{\prime \prime} \mathrm{W}$, and an Elevation of 173.40 metres. Daily data for each of the winter months for the years 2004 to 2010 was extracted in the monthly weather report summary formats. The months starting with November and ending with April, inclusive, are considered the winter months and are treated as one season; therefore each season has a designation similar to 2004-2005. The report includes temperature, precipitation and wind recordings. A sample report for the month of December 2008 is shown in Figure 5.11. 


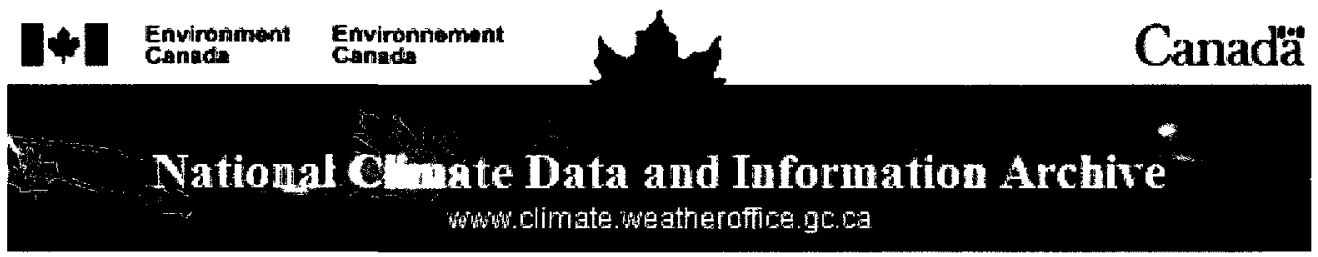

Dally Data Report for December 2008

\begin{tabular}{|c|c|c|c|c|c|c|c|c|c|c|c|}
\hline $\begin{array}{l}\mathrm{D} \\
\mathrm{a} \\
\mathrm{y}\end{array}$ & $\frac{\frac{\operatorname{Max}}{\operatorname{Temp}}}{\Delta}$ & $\frac{\frac{\operatorname{Min}}{\operatorname{Tem}}}{\frac{a c}{f}}$ & $\frac{\frac{\text { Mean }}{\text { Iemp }}}{{ }^{\circ} \mathrm{C}}$ & $\begin{array}{c}\frac{\text { Heat }}{\text { Dea }} \\
\frac{\text { Davs }}{{ }^{\circ} \mathrm{C}} \\
\text { d }\end{array}$ & $\begin{array}{l}\frac{\text { Cool }}{\text { Deg }} \\
\frac{\text { Davs }}{{ }^{\circ} \mathrm{C}} \\
\square\end{array}$ & $\frac{\text { Total }}{\frac{\text { Rain }}{\mathrm{mm}}}$ & $\frac{\frac{\text { Total }}{\text { Snowi }}}{\frac{\mathrm{cm}}{\mathrm{A}}}$ & $\frac{\text { Total }}{\text { Precie }} \underset{M}{\operatorname{mm}}$ & $\frac{\frac{\text { Snow }}{\text { on }}}{\frac{\mathrm{cm}}{\Delta}}$ & $\begin{array}{l}\text { Dir of } \\
\text { Max } \\
\text { Gust } \\
\text { 10's } \\
\text { Deg }\end{array}$ & $\frac{\text { Spd of }}{\frac{\text { Max }}{\text { Gust }}}$ \\
\hline$\underline{01}$ & 3.4 & -0.9 & 1.3 & 16.7 & 0.0 & 3.2 & 0.4 & 3.6 & 0 & 21 & 46 \\
\hline 02 & 0.6 & -1.6 & -0.5 & 18.5 & 0.0 & 0.0 & $T$ & $T$ & $T$ & 26 & 44 \\
\hline$\underline{03}$ & 6.4 & -1.0 & 2.7 & 15.3 & 0.0 & 0.4 & 0.0 & 0.4 & 0 & 20 & 44 \\
\hline 04 & 4.8 & -4.3 & 0.3 & 17.7 & 0.0 & 1.0 & $T$ & 1.0 & 0 & 27 & 56 \\
\hline$\underline{05}$ & -2.2 & -8.0 & -5.1 & 23.1 & 0.0 & 0.0 & $T$ & $T$ & 0 & 26 & 52 \\
\hline 06 & -1.7 & -6.6 & -4.2 & 22.2 & 0.0 & 0.0 & 2.2 & 1.8 & $T$ & 19 & 37 \\
\hline 0.7 & -2.1 & -12.7 & -7.4 & 25.4 & 0.0 & 0.0 & $T$ & $T$ & 2 & 30 & 63 \\
\hline$\overline{08}$ & -2.6 & -11.2 & -6.9 & 24.9 & 0.0 & 0.0 & 3.4 & 1.4 & 2 & & $<31$ \\
\hline D9 & 3.7 & -3.4 & 0.2 & 17.8 & 0.0 & 6.4 & 6.0 & 12.4 & 6 & & $<31$ \\
\hline 10 & 2.6 & -9.6 & -3.5 & 21.5 & 0.0 & 3.6 & 0.4 & 4.2 & 2 & 34 & 44 \\
\hline 11 & -1.8 & -10.1 & -6.0 & 24.0 & 0.0 & 0.0 & 0.0 & 0.0 & 1 & & $<31$ \\
\hline 12 & -1.4 & -11.9 & -6.7 & 24.7 & 0.0 & 0.0 & $T$ & $T$ & 1 & 29 & 41 \\
\hline 13 & 1.1 & -12.9 & -5.9 & 23.9 & 0.0 & 0.0 & 0.2 & 0.2 & 1 & 20 & 39 \\
\hline 14 & 5.1 & 0.6 & 2.9 & 15.1 & 0.0 & 1.0 & $T$ & 1.0 & 1 & 22 & 37 \\
\hline 15 & 10.6 & -7.3 & 1.7 & 16.3 & 0.0 & 3.8 & $T$ & 3.8 & 0 & 24 & 74 \\
\hline 16 & -3.3 & -7.6 & -5.5 & 23.5 & 0.0 & 0.0 & 4.4 & 4.0 & $T$ & & $<31$ \\
\hline 17 & -0.1 & -5.8 & -3.0 & 21.0 & 0.0 & 0.0 & 5.4 & 4.6 & 8 & 28 & 39 \\
\hline 18 & -2.2 & -8.4 & -5.3 & 23.3 & 0.0 & 0.0 & 0.0 & 0.0 & 7 & 26 & 33 \\
\hline 19 & -4.2 & -14.5 & -9.4 & 27.4 & 0.0 & 0.0 & 16.0 & 15.2 & 7 & 3 & 57 \\
\hline 20 & -10.4 & -17.7 & -14.1 & 32.1 & 0.0 & 0.0 & 0.4 & 0.2 & 22 & 7 & 32 \\
\hline 21 & -3.6 & -13.7 & -8.7 & 26.7 & 0.0 & 0.0 & 5.4 & 5.4 & 24 & 25 & 69 \\
\hline 22 & -7.1 & -13.5 & -10.3 & 28.3 & 0.0 & 0.0 & $\mathrm{~T}$ & $\mathrm{~T}$ & 24 & 30 & 59 \\
\hline 23 & -1.4 & -11.7 & -6.6 & 24.6 & 0.0 & 0.0 & 11.0 & 11.6 & 23 & 18 & 35 \\
\hline 24 & 6.1 & -1.5 & 2.3 & 15.7 & 0.0 & 10.8 & 1.8 & 12.6 & 36 & 27 & 93 \\
\hline 25 & 1.2 & -4.6 & -1.7 & 19.7 & 0.0 & 0.0 & 0.2 & 0.2 & 31 & 28 & 74 \\
\hline 26 & 2.5 & -4.9 & -1.2 & 19.2 & 0.0 & $T$ & 2.2 & 1.8 & 30 & & $<31$ \\
\hline 27 & 14.2 & 1.4 & 7.8 & 10.2 & 0.0 & 9.0 & 0.0 & 9.0 & 22 & 20 & 39 \\
\hline 28 & 15.9 & 0.1 & 8.0 & 10.0 & 0.0 & 0.8 & 0.0 & 0.8 & 2 & 25 & 93 \\
\hline$\overline{29}$ & 5.1 & -2.2 & 1.5 & 16.5 & 0.0 & $T$ & $T$ & $\mathrm{~T}$ & $T$ & 30 & 85 \\
\hline 30 & -0.5 & -5.9 & -3.2 & 21.2 & 0.0 & 0.0 & 3.8 & 3.4 & $\mathrm{~T}$ & 29 & 72 \\
\hline 31 & -5.8 & -14.3 & -10.1 & 28.1 & 0.0 & 0.0 & 1.6 & 1.2 & 5 & 31 & 57 \\
\hline Sum & & & & 654.6 & 0.0 & 40.0 & 64.8 & 99.8 & & & \\
\hline Avg & 1.1 & -7.3 & -3.1 & & & & & & & & \\
\hline xtrm & 15.9 & -17.7 & & & & & & & & 275 & 935 \\
\hline
\end{tabular}

Figure 5.11: Monthly Weather Records

[Environment Canada, 2010]

The weather data was then processed and sorted to provide daily data reports for the six winter seasons from 2004-2005 through to 2009-2010. Based on the winter season 
weather information, it is possible now to determine the frequency of storm occurrences within the study period for each winter season. Using the criteria established by the City for the four types of storms, and applying the criteria on the Environment Canada weather data for each of the winter seasons, the type, number, and total of snow storms for each season have been categorized and tabulated in Table 5.7. It is observed that the majority of snow storms are of type 1 and to a lesser extent of type 2 , while type 3 is infrequent, and type 4 is extremely rare. Further, using the same categorization on a monthly basis rather than seasonal, it can be seen that the months of December, January and February have the most number of storm occurrences, and the most are of type 1 snow storms, which is less than five centimetres of accumulations per storm. Figure 5.12 shows the monthly frequency of the four types of snow storms for the winter months within the study period.

Table 5.7: Snow Storm Type and Frequency

\begin{tabular}{|c|c|c|c|c|c|}
\hline Winter Season & $\begin{array}{c}\text { Snow } \\
\text { Storm } \\
\text { Type 1 } \\
0-5 \mathrm{~cm}\end{array}$ & $\begin{array}{c}\text { Snow } \\
\text { Storm } \\
\text { Type 2 } \\
5-15 \mathrm{~cm}\end{array}$ & $\begin{array}{c}\text { Snow } \\
\text { Storm } \\
\text { Type 3 } \\
15-25 \mathrm{~cm}\end{array}$ & $\begin{array}{c}\text { Snow } \\
\text { Storm } \\
\text { Type 4 } \\
>25 \mathrm{~cm}\end{array}$ & $\begin{array}{c}\text { Total } \\
\text { number } \\
\text { of Snow } \\
\text { Storms }\end{array}$ \\
\hline $\mathbf{2 0 0 4 - 2 0 0 5}$ & 67 & 10 & - & - & $\mathbf{7 7}$ \\
\hline $\mathbf{2 0 0 5 - 2 0 0 6}$ & 74 & 5 & - & - & $\mathbf{7 9}$ \\
\hline $\mathbf{2 0 0 6 - 2 0 0 7}$ & 79 & 4 & - & - & $\mathbf{8 3}$ \\
\hline $\mathbf{2 0 0 7 - 2 0 0 8}$ & 78 & 8 & 2 & 1 & $\mathbf{8 9}$ \\
\hline $\mathbf{2 0 0 8 - 2 0 0 9}$ & 68 & 10 & 1 & - & $\mathbf{7 9}$ \\
\hline $\mathbf{2 0 0 9 - 2 0 1 0}$ & 56 & 2 & - & - & $\mathbf{5 8}$ \\
\hline
\end{tabular}




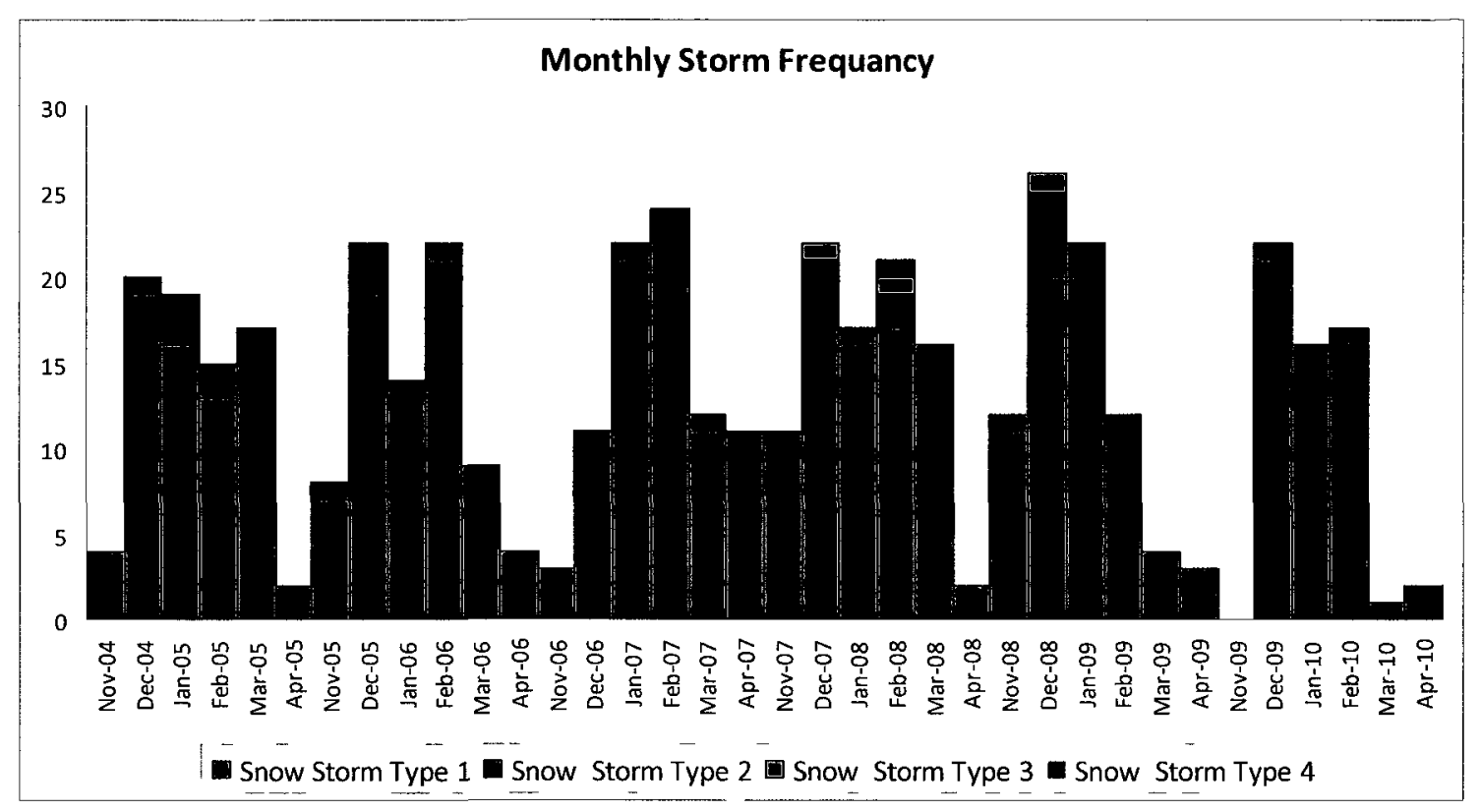

Figure 5.12: Monthly Snow Storm Frequency

\subsection{Winter Operation's Data from the City of Toronto}

Operational data was obtained from the Toronto's Transportation Services West District (Etobicoke-York). The amount of data available was rather massive; therefore, the data sample was limited to the one district above, and more specifically for the contracted winter services. Data records were extracted from the Toronto Maintenance Management System (TMMS), an activity based maintenance management system used to record, track, and pay for in-house resources and outsourced services. The data sample included a significant number of records. A record refers to one line of data with 41 columns; a sample raw data screen capture is shown in Figure 5.13. The number of records extracted from TMMS for each winter season is listed in Table 5.8. 
Table 5.8: Raw Data Records used in Study

\begin{tabular}{|c|c|}
\hline Winter Season & No. of Data Records \\
\hline $2004-2005$ & 6339 \\
\hline $2005-2006$ & 4629 \\
\hline $2006-2007$ & 4279 \\
\hline $2007-2008$ & 7441 \\
\hline $2008-2009$ & 3210 \\
\hline $2009-2010$ & 1463 \\
\hline
\end{tabular}

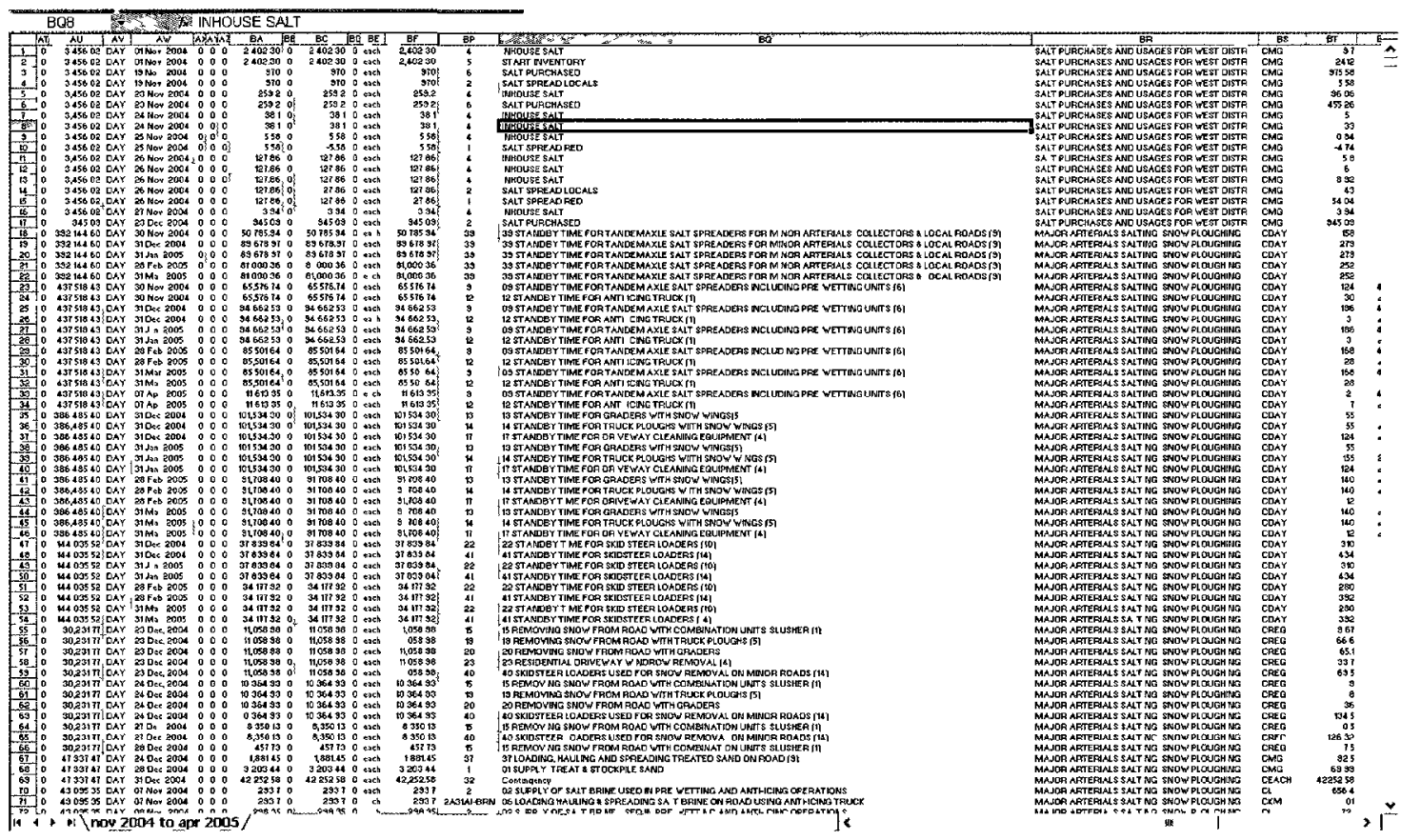

Figure 5.13: Winter Operations Raw Data -Screen Capture

The raw data obtained was for contracted services which included salting, antiicing and plowing for the West District. The data records also contained other activities such as loading and unloading salt, equipment standby time payments, staff standby time, shift and overtime premiums, and contingency maintenance, as well as some in-house information. The focus was on slating and anti-icing vehicles hired under contract at the 
two maintenance depots within the west district road operation. Those hired units are believed to have the most representative records for decision-making for mobilization. Also known as callouts, mobilizations represent how many times the vehicles were called out for service. The data was manipulated to extract the records that directly relate to vehicle mobilization; accordingly other records were ignored. This was done for the two focus activities of this research, namely salting and anti-icing. Winter maintenance equipment is identified as a 'resource' within TMMS, using the units' identification numbers, in combination with resource descriptions and position descriptions, and applying successive data filtering techniques, a reduced data set was produced. The data set includes dates of mobilization, number of mobilizations for each date, number of vehicle units mobilized per day, and the amount of kilometres driven collectively by all units deployed that day, and the type of operation carried out whether salting or antiicing. Table 5.9 shows a sample of the reduced data set, which is also included in Appendix B.

The data terminologies and descriptions differed slightly for the seasons of 2004$2005,2005-2006,2006-2007$, and 2007-2008, from those of the winter seasons of 20082009 and 2009-2010. This could be attributed to change in contract service providers, where one contract concluded at the end of the winter season in 2008 and another started for the following winter season in 2008-2009. However the differing terminologies were unified in the reduced data set and operations were grouped under unified activity labels of Anti-icing and Salting. Other concerns with the raw data were measurement units for 
salting and anti-icing. They have been per the kilometre driven, which has been consistent throughout the study period. However, only three winter seasons had records of few incidents where the service measurement units were by the hour of service. These occurrences were infrequent and near negligible for the purpose of calculating the number of vehicle deployments. It could however affect the distance driven for each winter event, but not enough to alter the calculations. The few incidents of hourly charges were extracted, and their presumed values in terms of kilometres were included in the total number of kilometres.

Table 5.9: Sample Data - Winter Mobilization

\begin{tabular}{|c|c|c|c|c|c|}
\hline \multicolumn{6}{|c|}{$\begin{array}{c}\text { Mobilization Data for Winter 2004-2005 } \\
\text { City of Toronto - West District }\end{array}$} \\
\hline $\begin{array}{l}\text { Winter } \\
\text { Day } \\
\text { No. }\end{array}$ & Date & $\begin{array}{l}\text { Mobilization } \\
\text { Per Date } \\
\text { Totals }\end{array}$ & $\begin{array}{l}\text { Units } \\
\text { per Day }\end{array}$ & $\begin{array}{l}\text { KM } \\
\text { Driven } \\
\text { per Day }\end{array}$ & Operation \\
\hline 3 & 03-Nov-2004 & 1 & 1 & 22.8 & Salting \\
\hline 7 & 07-Nov-2004 & 2 & 2 & 258 & Anti-icing \\
\hline 8 & 08-Nov-2004 & 2 & 2 & 258 & Anti-icing \\
\hline 11 & 11-Nov-2004 & 2 & 2 & 258 & Anti-icing \\
\hline 13 & 13-Nov-2004 & 2 & 2 & 258 & Anti-icing \\
\hline 25 & 25-Nov-2004 & 17 & 17 & 436.2 & Salting \\
\hline 26 & 26-Nov-2004 & 61 & 40 & 1709.34 & Salting \\
\hline 28 & 28-Nov-2004 & 2 & 2 & 258 & Anti-icing \\
\hline 31 & 01-Dec-2004 & 2 & 2 & 258 & Anti-icing \\
\hline 33 & 03-Dec-2004 & 2 & 2 & 258 & Anti-icing \\
\hline 34 & 04-Dec-2004 & 2 & 2 & 258 & Anti-icing \\
\hline 36 & 06-Dec-2004 & 100 & 38 & 2729.2 & Salting \\
\hline 37 & 07-Dec-2004 & 79 & 38 & 2097.12 & Salting \\
\hline 41 & 11-Dec-2004 & 76 & 38 & 2030.19 & Salting \\
\hline
\end{tabular}

Analyzing the reduced data set further, it is possible to calculate the following:

- Mobilization Days: days where at least one salt spreader or anti-icing unit was called out for service. 
- Service Trips: indicates the number of mobilizations (i.e. callouts, trips, beats, routes) per day of mobilization.

- Trip-Vehicles: is the total number of vehicles mobilized per season, for each day of mobilization regardless of how many trips they have done on that particular day. Trip-vehicle totals are the aggregation of "units per day" shown in Table 5.9 for the each of winter seasons.

- Kilometres Driven: The number of service kilometres driven by all vehicles during mobilization days within a winter season.

The mobilization information was combined with the corresponding weather information to show the number of mobilization days, alongside the number of snow days and the total snow accumulation per winter season as presented in Table 5.10. For example, for the winter season of 2004-2005, the summary indicates that there were 83 days in that season where at least a single salt spreader truck was mobilized. In those 83 days, there were 4,541 individual salting trips performed by 2,111 trip-vehicles, driving a total of 141,896 kilometres.

Table 5.10: Winter Mobilization and Weather Data Summary

\begin{tabular}{|c|c|c|c|c|c|c|}
\hline $\begin{array}{c}\text { Winter } \\
\text { Season }\end{array}$ & $\begin{array}{c}\text { Mobilization } \\
\text { Days }\end{array}$ & $\begin{array}{c}\text { Service } \\
\text { Trips }\end{array}$ & $\begin{array}{c}\text { Trip- } \\
\text { Vehicle }\end{array}$ & $\begin{array}{c}\text { Km's } \\
\text { Driven }\end{array}$ & $\begin{array}{c}\text { No. of } \\
\text { Snow } \\
\text { Days }\end{array}$ & $\begin{array}{c}\text { Total } \\
\text { Snowfall }\end{array}$ \\
\hline $2004-2005$ & 83 & 4,541 & 2,111 & 141,896 & 77 & 148.1 \\
\hline $2005-2006$ & 62 & 4,053 & 1,232 & 112,419 & 79 & 85.0 \\
\hline $2006-2007$ & 58 & 3,851 & 1,389 & 125,415 & 83 & 60.3 \\
\hline $2007-2008$ & 80 & 5,871 & 2,209 & 187,483 & 89 & 194.0 \\
\hline $2008-2009$ & 74 & 1,987 & 1,986 & 103,066 & 79 & 152.7 \\
\hline $2009-2010$ & 54 & 1,227 & 1,226 & 65,263 & 58 & 52.4 \\
\hline
\end{tabular}




\subsection{Synthesis of Findings and Implications}

Using the combined data set of operational and weather data, and for the analysis of anti-icing and salting mobilizations, the following terminologies are used:

- Anti-icing Mobilization Days: Number of days where at least one unit was mobilized for anti-icing operations.

- Salting Mobilization Days: Number of days where at least one unit was mobilized for salting operations.

- Anti-icing \& Snowfall Days: Number of days where at least one unit was mobilized for anti-icing operations, and at least a trace of snowfall were recorded.

- Salting \& Snowfall Days: Number of days where at least one unit was mobilized for salting operations, and at least a trace of snowfall was recorded.

- Snowfall without Mobilization Days: Number of days where at least a trace of snowfall was recorded and no units were mobilized.

- Anti-icing Mobilization without Snowfall: Number of days where at least one unit was mobilized for anti-icing operations, and no snowfall was recorded for the same day.

- Salting Mobilization without Snowfall: Number of days where at least one unit was mobilized for salting operations and no snowfall was recorded for the same day.

- Storm Days or Snow Days: Number of days where at least a trace of snowfall was recorded 
- Snowfall Amount: The amount of annual cumulative snowfall recorded daily for the subject weather station by Environment Canada, measured in centimetres.

\subsubsection{Analysis for Anti-icing Decisions}

While Anti-icing is relatively recent to the winter maintenance operation, it has been slowly integrated and utilized. The complement of anti-icing units dedicated for anti-icing operations within the study area has increased from 2 units to 4 units starting the winter of 2008-2009. The number of units is not critical to this analysis as it is focused on the number of times a decision was made to mobilize those units. The objective here is to investigate how many times the anti-icing units were called out and if that decision was appropriate for the weather and road conditions. The antiicing mobilization days are summarised in Table 5.11. It is observed that there are incidents where anti-icing units were mobilized with no recorded snowfall events. However, in order to qualify these decisions, the anti-icing days were compared to weather and RWIS data for the same days. This included air and pavement temperatures as well as snowfall records. Air temperatures were obtained from the Environment Canada weather archives, and pavement temperatures were obtained from the City's RWIS website. Unfortunately the data from RWIS was only available for the last 3 winter seasons of the study period. 
Table 5.11: Anti-icing Mobilizations

\begin{tabular}{|c|c|c|c|}
\hline Winter Season & $\begin{array}{c}\text { Anti-icing } \\
\text { Mobilization Days }\end{array}$ & $\begin{array}{c}\text { Anti-icing \& Snowfall } \\
\text { Days }\end{array}$ & $\begin{array}{c}\text { Anti-icing } \\
\text { Mobilization } \\
\text { without Snowfall }\end{array}$ \\
\hline $2004-2005$ & 19 & 6 & 13 \\
\hline $2005-2006$ & 24 & 13 & 11 \\
\hline $2006-2007$ & 14 & 2 & 12 \\
\hline $2007-2008$ & 8 & 5 & 3 \\
\hline $2008-2009$ & 13 & 7 & 6 \\
\hline $2009-2010$ & 16 & 3 & 13 \\
\hline
\end{tabular}

Referring to Table 5.11, it is observed for the winter of 2007-2008 that the anti-icing units had been mobilized a total of 8 times, 3 of which had been with no snowfall recoded. This is near $38 \%$ of over mobilization. However, when examining the minimum and max temperatures of the 3 missed days, it is found that 2 days had a pavement temperature of less than one degree Celsius, while the max pavement temperature on all three days had reached above 9 degrees Celsius, which would not allow any precipitation to form ice on the road. This means that at least one of the anti-icing mobilizations could have been avoided, provided a more reliable pavement condition forecast had been used in making the decision to mobilize the anti-icing units. Similarly, for winter $2008-2009$, it is observed a $46 \%$ of possible false mobilizations, and upon further examination of the daily pavement temperature extremes, they indicate that 5 of the 6 mobilizations could have been eliminated due to higher pavement temperatures (ranging from a minimum of 1 degree Celsius up to a maximum of 26 degrees Celsius. Meanwhile, for winter of 2009-2010 it is observed 
that there was 13 days of mobilization without snowfall, and based on pavement temperatures, 6 of the 13 days of mobilizations could have been avoided.

It should be understood that an anti-icing activity is called out in anticipation of snowfall, which may give rise to realization that anti-icing is highly speculative, and requires an increased level of experience and judgement. Nevertheless, it is possible to enhance the accuracy for mobilization decisions by employing more reliable pavement forecasts, and increased usage of live pavement temperature monitoring.

\subsubsection{Analysis for Salting Decisions}

The decision to mobilize salting operations is by virtue of its nature less speculative than decisions to mobilize for anti-icing, as they are usually a direct response to snow falling on the road. However, it is not an exact science, and there is still some degree of speculation since it also relies on weather forecasts. Premature mobilization, or under-mobilization, may be caused when the decision is based on inaccurate or incomplete information. The operation could also continue with the deployment of salt spreaders beyond what is required. The objective of this analysis is to investigate how many times the salting units were called out, and if these decisions were appropriate for the weather, and subsequently to compare the results with winter vehicular collision data. Table 5.12 shows a summary, per winter season, of mobilization frequency of salting units against the number of days with snowfall accumulations. 
Table 5.12: Salting Mobilization Days

\begin{tabular}{|c|c|c|c|c|c|}
\hline Column ID. & A & B & C & D & $E$ \\
\hline & & & \multicolumn{2}{|c|}{$\begin{array}{c}\text { Salting Mobilization without } \\
\text { Snowfall }\end{array}$} & \\
\hline $\begin{array}{l}\text { Winter } \\
\text { Season }\end{array}$ & $\begin{array}{c}\text { Salting } \\
\text { Mobilization } \\
\text { Days }\end{array}$ & $\begin{array}{c}\text { Salting \& } \\
\text { Snowfall } \\
\text { Days }\end{array}$ & $\begin{array}{l}\text { Salting } \\
\text { Mobilization } \\
\text { with a day of } \\
\text { snow earlier }\end{array}$ & $\begin{array}{c}\text { Possible } \\
\text { Premature } \\
\text { Mobilization }\end{array}$ & $\begin{array}{c}\% \text { missed of } \\
\text { Total } \\
\text { Mobilization } \\
(E=D / A)\end{array}$ \\
\hline 2004-2005 & 64 & 54 & 6 & 4 & $6.25 \%$ \\
\hline $2005-2006$ & 38 & 33 & 4 & 1 & $2.63 \%$ \\
\hline $2006-2007$ & 43 & 39 & 2 & 2 & $4.65 \%$ \\
\hline $2007-2008$ & 71 & 54 & 9 & 8 & $11.27 \%$ \\
\hline $2008-2009$ & 61 & 51 & 5 & 5 & $8.20 \%$ \\
\hline $2009-2010$ & 38 & 33 & 4 & 1 & $2.63 \%$ \\
\hline
\end{tabular}

The data shows that the number of salting mobilization days is greater than the number of days where it coincided with snowfall. Upon further investigation, the number of days where a snow event was recorded a day earlier were separated and excluded from the count. Those days were either an isolated one-day snowfall event or part of a seemingly multi-day snow storm. The result was calculating the number of days where a decision made to mobilize may have been premature or unwarranted.

With an assumption that a mobilization call is made every time there is snow on the ground, then the number of snowfall days with "Trace" of snow need to be excluded from the counts, which means that while there is snowfall occurring, it may not necessarily mean snow accumulation. Table 5.13 shows that there is close 
proximity of the number of snow days with accumulations and the actual number of days of mobilization with snowfall. This may indicate that the cause of premature mobilization is mainly within the days of trace snowfall rather than within days with significant snowfall accumulation.

Table 5.13: Salting Mobilization Days vs. Snow Days

\begin{tabular}{|c|c|c|c|c|}
\hline \multirow[b]{2}{*}{$\begin{array}{l}\text { Winter } \\
\text { Season }\end{array}$} & \multirow[b]{2}{*}{$\begin{array}{c}\text { Salting } \\
\text { Mobilization } \\
\text { Days }\end{array}$} & \multirow[b]{2}{*}{$\begin{array}{c}\text { Salting \& } \\
\text { Snowfall } \\
\text { Days }\end{array}$} & \multicolumn{2}{|c|}{$\begin{array}{l}\text { Salting Mobilization without } \\
\text { Snowfall }\end{array}$} \\
\hline & & & \begin{tabular}{|c|} 
Salting \\
Mobilization \\
with previous \\
snow day \\
\end{tabular} & $\begin{array}{c}\text { Possible } \\
\text { Premature } \\
\text { Mobilization } \\
\text { Days } \\
\end{array}$ \\
\hline 2004-2005 & 64 & 54 & 6 & 4 \\
\hline 2005-2006 & 38 & 33 & 4 & 1 \\
\hline $2006-2007$ & 43 & 39 & 2 & 2 \\
\hline $2007-2008$ & 71 & 54 & 9 & 8 \\
\hline 2008-2009 & 61 & 51 & 5 & 5 \\
\hline 2009-2010 & 38 & 33 & 4 & 1 \\
\hline
\end{tabular}

\begin{tabular}{|c|c|c|}
\hline \multicolumn{3}{|c|}{ Snow Days } \\
\hline $\begin{array}{c}\text { Days with } \\
\text { "Trace" } \\
\begin{array}{c}\text { Snowfall } \\
\text { only }\end{array}\end{array}$ & $\begin{array}{c}\text { Days with } \\
\text { Snowfall } \\
\text { above } \\
\text { "Trace" }\end{array}$ & $\begin{array}{c}\text { Total } \\
\text { Snow } \\
\text { Storm } \\
\text { Days }\end{array}$ \\
\hline 24 & 53 & 77 \\
\hline 39 & 40 & 79 \\
\hline 45 & 38 & 83 \\
\hline 33 & 56 & 89 \\
\hline 33 & 46 & 79 \\
\hline 29 & 29 & 58 \\
\hline
\end{tabular}

While the above is focused on the number of times the decision was made or missed, it is worth directing some attention to the strength, or the level of effort, of the response. It is not unusual that the decision to mobilize applies only to some salt spreaders rather than the full fleet. This measured mobilization could be as little as one unit, and up to the full complement of the assigned fleet within the study area.

One method, to measure the level of effort exerted in mobilization, is the amount of kilometres driven by the salt spreaders during the spreading of salt for road de-icing operations. The total kilometres driven were aggregated from the reduced data set in Appendix B. Using the total seasonal snow accumulation, it is possible to 
calculate the level of effort in terms of the number of kilometres required to treat one centimetre of snowfall. Using the study period average for the amount of kilometres driven per centimetre of snowfall, and comparing each kilometre per centimetre result against the study period average and expressing it in percentages, a $100 \%$ reading means the effort is at average, while a $107 \%$ means that there was $7 \%$ more effort applied for this season than the average for the study period. It can be observed that the winter season of 2008-2009 has the lowest level of effort, with $43 \%$ below the average, versus the winter of 2006-2007 that has the highest, with $73 \%$ more effort than the study period average. Results are summarized in Table 5.14. It should be noted that the highest snowfall, within the study period, was recorded in 2007-2008 and the lowest in 2009-2010, which does not reconcile with the average expectation of the applied level of effort. This is an indication that decisions for winter operations are not made with the same consistency, and do not resemble a direct relation to prevailing road conditions. However, it should also be noted that this method does not take into account how many days of snowfall it took for all the snow to accumulate for the season. 
Table 5.14: Level of Effort - Kilometres per Centimetre of Snow Salted

\begin{tabular}{|c|c|c|c|c|}
\hline Column ID. & A & B & C & D \\
\hline Winter Season & $\begin{array}{c}\text { Aggregated Daily } \\
\text { Kilometres Driven } \\
\text { per Season }\end{array}$ & $\begin{array}{c}\text { Snowfall } \\
\text { amount } \\
(\mathbf{c m})\end{array}$ & $\begin{array}{c}\text { km per cm of } \\
\text { snow } \\
\text { variation from } \\
\text { study period } \\
\text { average of km } \\
\text { per cm of } \\
\text { snow }\end{array}$ \\
\hline $2004-2005$ & 136,952 & 148.1 & 924.73 & $79 \%$ \\
\hline $2005-2006$ & 105,879 & 85 & $1,245.64$ & $107 \%$ \\
\hline $2006-2007$ & 121,503 & 60.3 & $2,014.97$ & $173 \%$ \\
\hline $2007-2008$ & 185,083 & 194 & 954.03 & $82 \%$ \\
\hline $2008-2009$ & 100,810 & 152.7 & 660.19 & $57 \%$ \\
\hline $2009-2010$ & 61,838 & 52.4 & $1,180.11$ & $101 \%$ \\
\hline
\end{tabular}

It is also possible to measure the level of effort applied for slat spreading operations, based on the total seasonal snowfall, in relation to the number of days with significant snow accumulation with more than a trace of snowfall. This produces an average seasonal daily snow accumulation per day of snowfall. For example, the winter of 2006-2007 had an average seasonal daily snow accumulation of $1.59 \mathrm{~cm}$, while for 2007-2009 it was $3.46 \mathrm{~cm}$. Using this average multiplied by the number of salting mobilization days, then one can estimate the theoretical capacity of snow accumulation, that would have been treated by salting for that winter season. Comparing this theoretical capacity with the actual snowfall for the season may determine if the mobilization each season was over or under what was required. Table 5.15 shows that for 5 of the 6 seasons in the study period may possibly be overmobilized by as much as $33 \%$ from the theoretical salting capacity. 
Table 5.15: Level of Mobilization vs. Theoretical Salting Capacity

\begin{tabular}{|c|c|c|c|c|c|c|c|}
\hline Column ID. & A & B & C & D & E & F & G \\
\hline $\begin{array}{c}\text { Winter } \\
\text { Season }\end{array}$ & $\begin{array}{c}\text { Salting } \\
\text { Mobilization } \\
\text { Days }\end{array}$ & $\begin{array}{c}\text { Salting \& } \\
\text { Snowfall } \\
\text { Days }\end{array}$ & $\begin{array}{c}\text { Days with } \\
\text { Snowfall } \\
\text { above } \\
\text { "Trace" }\end{array}$ & $\begin{array}{c}\text { Snowfall } \\
\text { amount } \\
\text { (cm) }\end{array}$ & $\begin{array}{c}\text { Average } \\
\text { Seasonal } \\
\text { Daily Snow } \\
\text { accumulation } \\
\text { (cm/day) }\end{array}$ & $\begin{array}{c}\text { Theoretical } \\
\text { capacity of } \\
\text { salting of } \\
\text { snowfall for } \\
\text { actual days of } \\
\text { mobilization } \\
\text { (cm/year) }\end{array}$ & $\begin{array}{c}\text { Possible } \\
\text { Variation in } \\
\text { Mobilization } \\
\text { per Seasonal } \\
\text { Snowfall }\end{array}$ \\
\hline $2004-2005$ & 64 & 54 & 53 & 148.1 & 2.79 & 178.84 & $121 \%$ \\
\hline $2005-2006$ & 38 & 33 & 40 & 85 & 2.13 & 80.75 & $95 \%$ \\
\hline $2006-2007$ & 43 & 39 & 38 & 60.3 & 1.59 & 68.23 & $113 \%$ \\
\hline $2007-2008$ & 71 & 54 & 56 & 194 & 3.46 & 245.96 & $127 \%$ \\
\hline $2008-2009$ & 61 & 51 & 46 & 152.7 & 3.32 & 202.49 & $133 \%$ \\
\hline $2009-2010$ & 38 & 33 & 29 & 52.4 & 1.81 & 68.66 & $131 \%$ \\
\hline
\end{tabular}

\subsubsection{Winter Collisions Analysis}

The City of Toronto keeps annual statistics on road traffic collisions. The collision data includes information on road surface condition at the time of the collision. This information has been extracted to show winter season collision by road surface condition, summarized in Table 5.16. It should be noted that the data has been accumulated from city wide incidents. However, the study area is one district only. Nevertheless, it is assumed that the west district operational data is representative of the city's winter operations. The collision information presented in Table 5.16 is for winter road surface condition, as identified by Toronto Police on collision reports. 
Table 5.16: Winter Season Collision by Road Surface Condition (Source: City of Toronto \& Toronto Police Service)

\begin{tabular}{|c|c|c|c|c|c|}
\hline \multirow{2}{*}{ Winter Season Collision by Road Surface Condition } \\
\cline { 2 - 5 } Winter Season & \multicolumn{3}{|c|}{ Road Surface Conditions } & \multirow{2}{*}{$\begin{array}{c}\text { Total } \\
\text { Coollisions }\end{array}$} \\
\cline { 2 - 5 } & $\begin{array}{c}\text { Snow } \\
\text { Soose }\end{array}$ & Ice & Slush & $\begin{array}{c}\text { Packed } \\
\text { Snow }\end{array}$ & C,941 \\
\hline $2005-2006$ & 1,924 & 1,323 & 991 & 703 & 2,313 \\
\hline $2006-2007$ & 1,101 & 601 & 608 & 277 & 2,587 \\
\hline $2007-2008$ & 1,909 & 967 & 887 & 741 & 4,504 \\
\hline $2008-2009$ & 1,866 & 887 & 1,017 & 563 & 4,333 \\
\hline $2009-2010$ & 588 & 316 & 389 & 135 & 1,428 \\
\hline
\end{tabular}

Taking the analysis further, and using the aggregated number of collisions that have been attributed to winter surface conditions, as presented in Table 5.16, and calculating the variation of each seasonal reading with the average of collisions of the study period. This is shown against the variations of the number of kilometres driven for each centimetre of seasonal snowfall, as shown in Table 5.14, then, it is necessary to join the percent variations in Table 5.17 in order to show possible patterns for such variations. Furthermore, using column $\mathrm{D}$ and column $\mathrm{F}$ from Table 5.17, and illustrating them graphically as shown in Figure 5.14, it is observed that a trend is manifested, in that the variations of both values indicate an opposite relationship in that increases in variation for level of effort seem to correspond to decreases in variations for collisions. 
Table 5.17: Kilometres per Centimetre of Snow and Winter Collisions

\begin{tabular}{|c|c|c|c|c|c|c|}
\hline Column ID. & A & B & C & D & E & F \\
\hline $\begin{array}{c}\text { Winter } \\
\text { Season }\end{array}$ & $\begin{array}{c}\text { Aggregated } \\
\text { Daily } \\
\text { Kilometres } \\
\text { Driven per } \\
\text { Season }\end{array}$ & $\begin{array}{c}\text { Seasonal } \\
\text { Snowfall } \\
\text { amount } \\
(\mathbf{c m})\end{array}$ & $\begin{array}{c}\text { \%m per cm } \\
\text { from study } \\
\text { period } \\
\text { overage of } \\
\text { km per cm } \\
\text { of snow }\end{array}$ & $\begin{array}{c}\text { Winter } \\
\text { Road } \\
\text { Condition }\end{array}$ & $\begin{array}{c}\text { \% Variation } \\
\text { from study } \\
\text { period } \\
\text { average of } \\
\text { collisions }\end{array}$ \\
\hline $2004-2005$ & 136,952 & 148.1 & 924.73 & $79 \%$ & $\mathbf{4 , 9 4 1}$ & $147 \%$ \\
\hline $2005-2006$ & 105,879 & 85 & $1,245.64$ & $107 \%$ & $\mathbf{2 , 3 1 3}$ & $69 \%$ \\
\hline $2006-2007$ & 121,503 & 60.3 & $2,014.97$ & $173 \%$ & $\mathbf{2 , 5 8 7}$ & $77 \%$ \\
\hline $2007-2008$ & 185,083 & 194 & 954.03 & $82 \%$ & $\mathbf{4 , 5 0 4}$ & $134 \%$ \\
\hline $2008-2009$ & 100,810 & 152.7 & 660.19 & $57 \%$ & $\mathbf{4 , 3 3 3}$ & $129 \%$ \\
\hline $2009-2010$ & 61,838 & 52.4 & $1,180.11$ & $101 \%$ & $\mathbf{1 , 4 2 8}$ & $43 \%$ \\
\hline
\end{tabular}

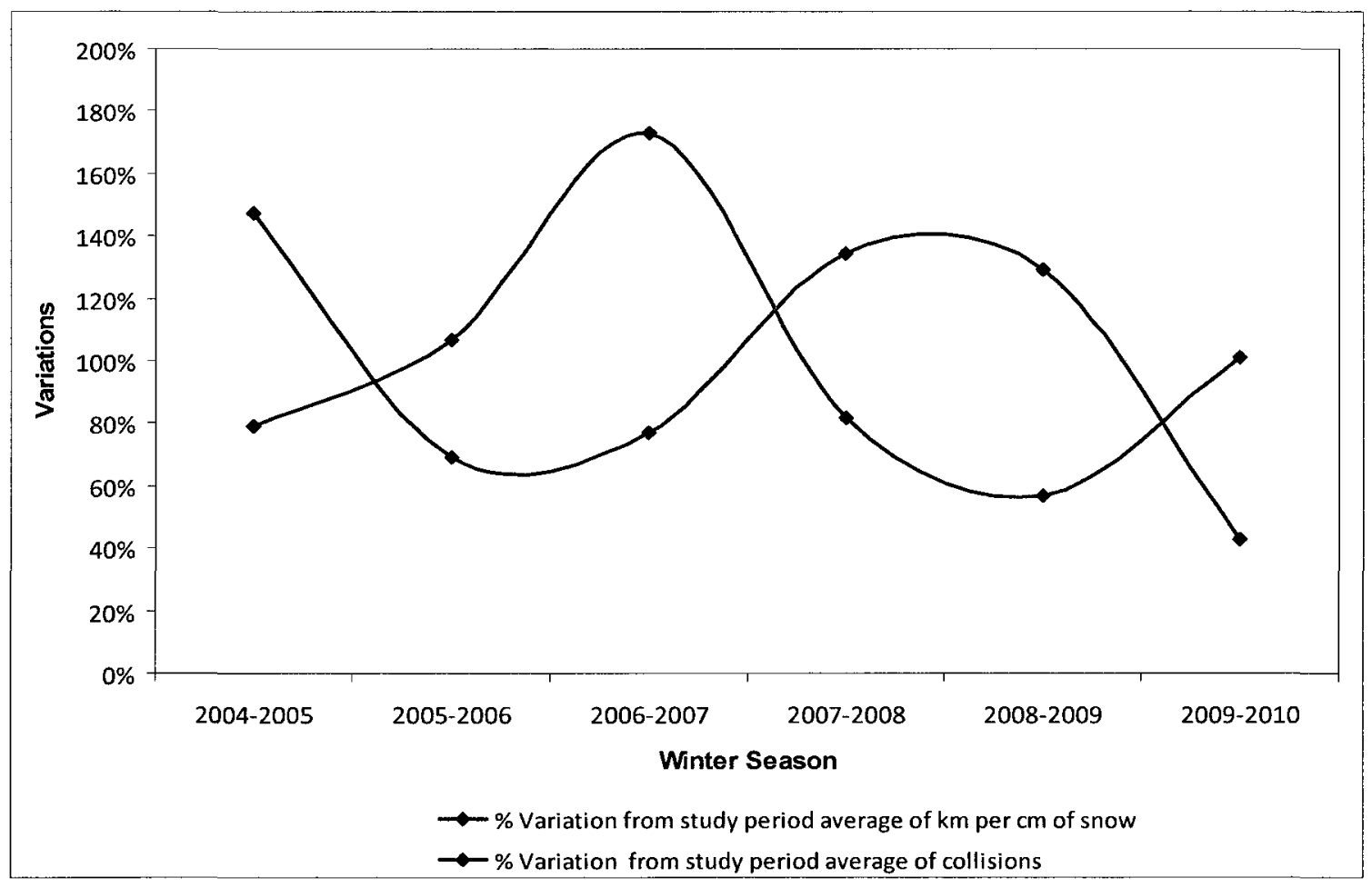

Figure 5.14: Kilometres Driven vs. Collisions Variations 


\subsubsection{Data Correlation}

Furthermore, to investigate a relationship between the various statistics arrived at during the analysis; Table 5.18 was compiled to show the main information identifying the winter maintenance operation within the study period. The columns of Table 5.18 have been identified with the letters A through F, with each column representing one operation's variable. Using the operation variables in Table 5.18, as identified by their column ID, a correlation matrix was developed in order to show the relationship between the various variables against each other. Table 5.19 shows the correlation matrix, noting that the correlation calculations were produced using Microsoft Excel correlation function.

Table 5.18: Study Period Winter Season Statistics

\begin{tabular}{|c|c|c|c|c|c|c|}
\hline Column ID. & A & B & C & D & E & F \\
\hline $\begin{array}{c}\text { Winter } \\
\text { Season }\end{array}$ & $\begin{array}{c}\text { Aggregated } \\
\text { Daily } \\
\text { Kilometres } \\
\text { Driven per } \\
\text { Season }\end{array}$ & $\begin{array}{c}\text { Seasonal } \\
\text { Snowfall } \\
\text { total } \\
\text { (cm) }\end{array}$ & $\begin{array}{c}\text { Total } \\
\text { Snowfa } \\
\text { Il Days } \\
\text { above } \\
\text { "Trace" }\end{array}$ & $\begin{array}{c}\text { Winter } \\
\text { Mobilization } \\
\text { Days } \\
\text { Road } \\
\text { Condition } \\
\text { Collisions }\end{array}$ & $\begin{array}{c}\text { seasonal Daily } \\
\text { Average } \\
\text { Snowfall (cm } \\
\text { of snow per } \\
\text { day of } \\
\text { snowfall) }\end{array}$ \\
\hline $2004-2005$ & $136,952.00$ & 148.1 & 53 & 64 & 4,941 & 2.79 \\
\hline $2005-2006$ & $105,879.00$ & 85 & 40 & 38 & 2,313 & 2.13 \\
\hline $2006-2007$ & $121,503.00$ & 60.3 & 38 & 43 & 2,587 & 1.59 \\
\hline $2007-2008$ & $185,083.00$ & 194 & 56 & 71 & 4,504 & 3.46 \\
\hline $2008-2009$ & $100,810.00$ & 152.7 & 46 & 61 & 4,333 & 3.32 \\
\hline $2009-2010$ & $61,838.00$ & 52.4 & 29 & 38 & 1,428 & 1.81 \\
\hline
\end{tabular}


Table 5.19: Winter Season Statistics -Correlation Matrix

\begin{tabular}{|c|c|c|c|c|c|c|}
\hline & \multicolumn{6}{|c|}{ Correlation Matrix } \\
\hline Column ID. & A & B & C & D & $\mathbf{E}$ & $\mathbf{F}$ \\
\hline A & 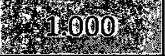 & 0.757 & 0.876 & 0.759 & 0.710 & 0.590 \\
\hline B & 0.757 & K 1.0006 & 0.936 & 0.962 & 0.911 & 0.970 \\
\hline C & 0.876 & 0.936 & 7000 & 0.923 & 0.944 & 0.834 \\
\hline D & 0.759 & 0.962 & 0.923 & 9. & 0.946 & 0.907 \\
\hline $\mathbf{E}$ & 0.710 & 0.911 & 0.944 & 0.946 & 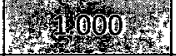 & 0.848 \\
\hline $\mathbf{F}$ & 0.590 & 0.970 & 0.834 & 0.907 & 0.848 & ratroom \\
\hline
\end{tabular}

Referring to Table 5.19, it can be observed that the strongest relationship seems to be between seasonal snowfall total and the number of salting mobilization days, (Column B \& D, r =.962), seconded by a strong relationship between winter collisions and number of salting days, which is rather interesting. One would expect that more salting days would result in fewer collisions; however, it seems that the number of collisions correlates positively and strongly with the amount of seasonal snowfall, number of snow days, and the number of mobilization days. This shows inconsistencies in the relationship between mobilization and collisions, which will require further research beyond the scope of this thesis. 


\section{CHAPTER 6 \\ CONCLUSIONS AND RECOMMENDATIONS}

\subsection{Conclusions}

Winter road maintenance operation is a series of activities performed at various times to keep roads safe and passable during severe winter conditions. Winter road maintenance components must be coordinated to allow managers to make the right decisions at the right time. Key elements contributing to the decision-making process of winter road maintenance were explored for their influence over the operation. A framework for a systematic decision-making process was proposed, based on the identified key elements, including road weather monitoring and forecasting, pavement temperature, material types, and application techniques. Subsequently, a working data set was developed for a study period of six winter seasons from 2004 to 2010 . The data set consisted of post-event winter maintenance operations data from the City of Toronto, cross referenced to actual weather readings for the same period. The data set was showing deployment of maintenance vehicles as representation of decisions made for resource mobilizations. In addition, the associated winter related collision statistics were also included. Analysis of the data set was performed to examine the implication of decision actions, and to determine if there were any relationships between winter maintenance operational mobilizations, weather conditions, and winter related collisions. The following are conclusions and recommendations drawn from this study: 
- Key elements contributing to the decision-making process of winter road maintenance operations can be grouped as follows: 1) Weather, including snow and ice precipitation, weather monitoring, and forecasting. 2) Road, including road surface temperature, road surface condition, road classification, and traffic volumes. 3) Materials for winter control, including abrasives and chemical de-icers, de-icer working temperature range, material application techniques, and material spreading equipment. 4) Policies and procedures, including legislations, level of service, maintenance priorities, and decisionmakers organizational hierarchy. And, 5) Operational verification, including data collected from the winter road maintenance operations, such as type, amount, location, and timing of materials applied. The literature review had also revealed a deficiency in the utilization of decision support systems, that also includes a deficiency in incorporating feedback from the maintenance operation into the decision making process for the purpose of verification and decision adjustments.

- A framework was proposed for a systematic decision-making process for winter road maintenance operation. The proposed framework is based on staged processes, a pre-storm stage and sequential alternative stages for instorm actions; in-storm alternatives are dependant on decisions made in the preceding stage. The proposed framework would be customized to address the specific input variables for a particular road authority. The framework 
includes a series of decision points based on key operational elements, such as salt application rate change to correspond to road surface temperature. A framework encompassing a hierarchy for decision-making, a prescribed level of service, and a systematic approach designed around key operational elements will help in reducing the margin of decision error, and thus provide for more efficient winter road maintenance operations.

- Results of the analysis of actual post-event operational data allowed quantification of decisions in terms of number of vehicle mobilization recorded to deliver salting or anti-icing activities, and when cross-referenced with associated weather data, it was possible to estimate missed opportunities. However, applying the proposed framework would have reduced the number of possible premature decisions and would have resulted in cost savings. Furthermore, analysis of relationships between mobilization and number of kilometres driven for salting or anti-icing activities showed inconsistencies in the amount of effort applied for the treatment of a seasonal centimetre of snow. On the other hand the relationship between mobilization and collisions was inconclusive and will require further research.

- Measuring the effects of winter road maintenance decisions can be achieved by establishing value for decisions which is measured in terms of cost impact and level of effectiveness. This is done by measuring the number of 
kilometres driven to treat a seasonal centimetre of snow, whereby a seasonal centimetre of snow is calculated from the total seasonal snow accumulation divided by the number of snow accumulation days for that winter season. Quantifying efforts resulting from winter maintenance operational decisions allows for the benchmarking of operational decisions for effectiveness and efficiency.

\subsection{Recommendations and Future Work}

In order to further and better define relationships between decision-making, the various elements of the winter road maintenance operations, and the resulting effects, the following is recommended:

- That for road authorities, a decision tracking system be developed for road operations, whereby decisions are recorded every time based on clear definitions. Furthermore, it is recommended that such system be attached to a decisions database holding other relevant information to decisions being made, and aligned with key decision-making elements.

- That further research be undertaken, utilizing a study period that is longer than ten years, whereby a much larger working data set is developed for the purpose of such research. 


\section{REFERENCES}

[AASHTO, 1999] American Association of State Highway and Transportation Officials, Guide for Snow and Ice Control, Winter Maintenance Policy Coordinating Committee, Washington D.C. 1999.

[American

Highway, 2010]

American Highway Users Alliance, "The Economic Costs of Disruption from a Snowstorm", Study Prepared for the American Highway Users Alliance by IHS Global Insight, <www.highways.org>, Washington, DC, 2009.

[APWA, 1998] American Public Works Association, The Basics of Snow and Ice Control, Kansas City, 1998.

[Blackburn, 2004] Blackburn, R. R., Bauer, K. M., Amsler, Sr., D. E., Bossely, S. E., and McElroy, A. D., Snow and Ice Control: Guidelines for Materials and Methods, NCHRP Report 526, Transportation Research Board, Washington DC, 2004.

[Ottawa, 2005] City of Ottawa, Road Salt Management Plan. 5 May 2005. Transportation Committee and Council. $<$ http://www.ottawa.ca/calendar/ottawa/citycouncil/occ/2005/0713/trc/ACS2005-PWS-SOP-0002.htm>

[Toronto, 2009] City of Toronto, Salt Management Plan. Transportation Services Division. June 2009. 
[Crevier \& $\quad$ Crevier, L.P., and Delage, Y., METRo: A New Model for Road

Delage, 2001] Condition Forecasting in Canada, Journal of Applied

Meteorology, American Meteorological Society, Vol. 40, pp. 2026-2037, 2001.

[Environment Environment Canada, Code of Practice for the Environmental Canada, 2004] Management of Road Salts. April 2004.

$<\mathrm{http} / / /$ www.ec.gc.ca/nopp/roadsalt/cop/en/rs_main.htm>

[Environment Environment Canada, National Climate Data and Information Canada, 2010] Archive, Daily Data Report, http://www.climate.weatheroffice.gc.ca/climateData/dailydata_e.ht ml, (Accessed December 2010).

[Ontario, 2002] Government of Ontario, Minimum Maintenance Standards for Municipal Highways, Ontario Regulation 239/02 made under the Municipal Act, Made: July 23, 2002, Filed: August 8, 2002, Printed in The Ontario Gazette: August 24, 2002.

[Keep 2000] Keep, D., Parker, D., Proactive Guide to Snow and Ice Control A Guide for Winter Maintenance Personnel, Ice and Snow Technologies, LLC. Walla Walla, Washington, 2000.

[Jones, 2003] Jones, Brenda, Chapter 5: Road Maintenance Costs In Canada In Winter, Weather and Transportation in Canada, Edited by Andrey, J. and Knapper, C., Published by the Department of Geography, University of Waterloo, 2003. 
[FHWA, 1996] Ketcham, S. A., Minsk, L. D., Blackburn, R. R., and Fleege, E. J., Manual of Practice for an Effective Anti-Icing Program: A Guide for Highway Winter Maintenance Personnel, Report No. FHWARD-95-202, Federal Highway Administration, Washington, D.C., June 1996.

[FHWA, 2005] Manfredi, J., Walters, T., Wilke, G., Osborne, L. Hart, R., Incrocci, T., Schmitt, T., Road Weather Information System Environmental Sensor Station Siting Guidelines, Report No. FHWA-HOP-05-026, Federal Highway Administration, Office of Transportation Operations, Road Weather Management Program, Washington, D.C., April 2005.

[McDermott, McDermott, David. "The Ultimate Decision Making Model For 2008] You. " Decision Making Confidence for Easier and Faster Decision Making. <http://www.decision-making-confidence.com> (Accessed Aug. 2010).

[Minsk, 1998] Minsk, L.D., "Snow and Ice Control Manual for Transportation Facilities", McGraw Hill, New York NY, 1998.

[NCHRP 526, National Cooperative Highway Reserch Program, Report 526, 2004] Snow and Ice Control: Guidelines for Material and Methods, Transportation Research Board, Washington D.C. 2004. (page 11).

[NCHRP 207, National Cooperative Highway Reserch Program, Synthesis 207, 1997] Managing Roadway Snow and Ice Control Operations, Transportation Research Board, Washington D.C. 1994. 
[NCHRP 344, National Cooperative Highway Reserch Program, Synthesis 344, 2005] Winter Highway Operations, A Synthesis of Highway Practice. Transportation Research Board, Washington D.C. 2005.

[Papadakis, 1998] Papadakis, Vassilis M, et al. "Strategic Decision Making Processes: The Role of Management and Context.", Strategic Management Journal Vol. 19, 115-147, 1998.

[The Star, 2008] Carmen Chai, Snowstorm cleanup costs city $\$ 3$ million, article by The Toronto Star, thestar.com, published on Mon Feb 42008.

[Transport Transport Canada, "Estimates of the Full Cost of Transportation in Canada, 2008] Canada", Synthesis report, August 2008 http://www.tc.gc.ca/eng/policy/report-aca-fullcostinvestigationsynthesis-index-1523.html, (Accessed January 2011).

[Transport Transport Canada, "Transportation in Canada 2009, Annual Canada, 2010] Report - May 2010”, Economic Analysis Directorate Policy Group. http://www.tc.gc.ca/eng/policy/report-aca-anre2009-index2292.htm, (Accessed January 2011).

[TAC, 1999] Transportation Association of Canada, Salt Management Guide, Ottawa, 1999.

[Business 2010] WebFinance, Inc., BusinessDictionary.com. (Accessed January 24, 2010) $<$ http://www.businessdictionary.com/definition/decision.html $>$ 


\section{APPENDIX A}

Daily Data Report for Winter Weather Records Winter Seasons 2004-2005 to 2009-2010 
Daily Data Report for Winter 2004-2005

\begin{tabular}{|c|c|c|c|c|c|c|c|c|c|c|c|}
\hline \multicolumn{3}{|c|}{ Environment Canada } & \multicolumn{5}{|c|}{$\begin{array}{c}\text { National Climate Data and Information } \\
\text { Archive }\end{array}$} & \multicolumn{4}{|c|}{ www.climate.weatheroffice.gc.ca } \\
\hline Day & $\begin{array}{l}\text { Max } \\
\text { Temp }\end{array}$ & $\begin{array}{l}\text { Min } \\
\text { Temp }\end{array}$ & $\begin{array}{l}\text { Mean } \\
\text { Temp }\end{array}$ & $\begin{array}{l}\text { Heat } \\
\text { Deg } \\
\text { Days }\end{array}$ & \begin{tabular}{|l|} 
Cool \\
Deg \\
Days \\
\end{tabular} & $\begin{array}{l}\text { Total } \\
\text { Rain }\end{array}$ & $\begin{array}{l}\text { Total } \\
\text { Snow }\end{array}$ & $\begin{array}{l}\text { Total } \\
\text { Precip }\end{array}$ & $\begin{array}{l}\text { Snow } \\
\text { on } \\
\text { Grnd }\end{array}$ & $\begin{array}{l}\text { Dir of } \\
\text { Max } \\
\text { Gust }\end{array}$ & $\begin{array}{l}\text { Spd of } \\
\text { Max } \\
\text { Gust }\end{array}$ \\
\hline & ${ }^{\circ} \mathrm{C}$ & ${ }^{\circ} \mathrm{C}$ & ${ }^{\circ} \mathrm{C}$ & ${ }^{\circ} \mathrm{C}$ & ${ }^{\circ} \mathrm{C}$ & $\mathrm{mm}$ & $\mathrm{cm}$ & $\mathrm{mm}$ & $\mathrm{cm}$ & 10 's Deg & $\mathrm{km} / \mathrm{h}$ \\
\hline $31 / \mathrm{Oct} / 2004$ & 12.8 & 7 & 9.9 & 8.1 & 0 & $\mathrm{~T}$ & 0 & $\mathrm{~T}$ & 0 & 26 & 63 \\
\hline $01 /$ Nov/2004 & 10.9 & 6.3 & 8.6 & 9.4 & 0 & $T$ & 0 & $T$ & 0 & & $<31$ \\
\hline $02 /$ Nov/2004 & 9 & 5.3 & 7.2 & 10.8 & 0 & 13.2 & 0 & 13.2 & 0 & 33 & 50 \\
\hline $03 /$ Nov/2004 & 10.2 & 3.1 & 6.7 & 11.3 & 0 & 0 & 0 & 0 & 0 & 34 & 50 \\
\hline $04 / \mathrm{Nov} / 2004$ & 7.4 & 3.3 & 5.4 & 12.6 & 0 & 9.8 & 0 & 9.8 & 0 & 28 & 72 \\
\hline $05 /$ Nov/2004 & 8.6 & 2.7 & 5.7 & 12.3 & 0 & 2.6 & 0 & 2.6 & 0 & 31 & 78 \\
\hline $06 /$ Nov/2004 & 13.5 & 5.7 & 9.6 & 8.4 & 0 & 0 & 0 & 0 & 0 & 26 & 56 \\
\hline $07 /$ Nov/2004 & 14.7 & 2.4 & 8.6 & 9.4 & 0 & 0 & 0 & 0 & 0 & 29 & 59 \\
\hline $08 /$ Nov/2004 & 5.6 & -3.7 & 1 & 17 & 0 & 0 & 0 & 0 & 0 & 31 & 46 \\
\hline $09 /$ Nov/2004 & 2.9 & -4.6 & -0.9 & 18.9 & 0 & 0 & 0 & 0 & 0 & & $<31$ \\
\hline $10 /$ Nov/2004 & 13.4 & 2.8 & 8.1 & 9.9 & 0 & 0 & 0 & 0 & 0 & 23 & 46 \\
\hline $11 /$ Nov/2004 & 12.4 & -2.4 & 5 & 13 & 0 & 0 & 0 & 0 & 0 & 34 & 50 \\
\hline $12 / \mathrm{Nov} / 2004$ & 5.5 & -3.2 & 1.2 & 16.8 & 0 & 0 & 0 & 0 & 0 & & $<31$ \\
\hline $13 / \mathrm{Nov} / 2004$ & 4.9 & -3.1 & 0.9 & 17.1 & 0 & 0 & 0 & 0 & 0 & & $<31$ \\
\hline $14 /$ Nov/2004 & 10.2 & -3.2 & 3.5 & 14.5 & 0 & 0 & 0 & 0 & 0 & 29 & 32 \\
\hline $15 /$ Nov/2004 & 13.6 & -1.7 & 6 & 12 & 0 & 0 & 0 & 0 & 0 & & $<31$ \\
\hline $16 /$ Nov/2004 & 13.9 & 1.7 & 7.8 & 10.2 & 0 & 0 & 0 & 0 & 0 & & $<31$ \\
\hline $17 /$ Nov/2004 & 12.4 & 7.7 & 10.1 & 7.9 & 0 & 0.4 & 0 & 0.4 & 0 & & $<31$ \\
\hline $18 /$ Nov/2004 & 14.9 & 6.8 & 10.9 & 7.1 & 0 & 0.2 & 0 & 0.2 & 0 & & $<31$ \\
\hline $19 /$ Nov/2004 & 10 & 6.3 & 8.2 & 9.8 & 0 & 0.2 & 0 & 0.2 & 0 & & $<31$ \\
\hline $20 /$ Nov/2004 & 7.6 & 5.1 & 6.4 & 11.6 & 0 & 2.2 & 0 & 2.2 & 0 & 9 & 41 \\
\hline $21 /$ Nov/2004 & 10 & 3.9 & 7 & 11 & 0 & $\mathrm{~T}$ & 0 & $T$ & 0 & 28 & 35 \\
\hline $22 /$ Nov/2004 & 9.2 & 0.9 & 5.1 & 12.9 & 0 & 0 & 0 & 0 & 0 & & $<31$ \\
\hline $23 /$ Nov/2004 & 9.7 & 0.2 & 5 & 13 & 0 & $T$ & 0 & $T$ & 0 & 20 & 35 \\
\hline $24 /$ Nov/2004 & 7.6 & -0.1 & 3.8 & 14.2 & 0 & 14 & 2.4 & 16.4 & 0 & 1 & 52 \\
\hline $25 /$ Nov/2004 & 0.6 & -3.2 & -1.3 & 19.3 & 0 & 0.2 & $T$ & 0.2 & 0 & 33 & 54 \\
\hline $26 /$ Nov/2004 & 4.4 & -1.4 & 1.5 & 16.5 & 0 & 0 & 0.4 & 0.4 & $T$ & 25 & 32 \\
\hline $27 /$ Nov/2004 & 10.4 & 3.8 & 7.1 & 10.9 & 0 & 2 & 0 & 2 & 0 & & $<31$ \\
\hline $28 /$ Nov/2004 & 9.3 & 2.1 & 5.7 & 12.3 & 0 & 12.8 & $\mathrm{~T}$ & 12.8 & 0 & 25 & 65 \\
\hline $29 /$ Nov/2004 & 6.1 & 1.2 & 3.7 & 14.3 & 0 & 0 & 0 & 0 & 0 & 29 & 46 \\
\hline $30 / \mathrm{Nov} / 2004$ & 6.8 & -0.3 & 3.3 & 14.7 & 0 & 4.4 & 0 & 4.4 & 0 & & $<31$ \\
\hline $01 / \mathrm{Dec} / 2004$ & 5.2 & 1.1 & 3.2 & 14.8 & 0 & 9.7 & 2.5 & 12.2 & 0 & 33 & 70 \\
\hline $02 / \mathrm{Dec} / 2004$ & 3.6 & 0.5 & 2.1 & 15.9 & 0 & 0 & $T$ & $T$ & 0 & 26 & 33 \\
\hline $03 / \mathrm{Dec} / 2004$ & 1.5 & -5.7 & -2.1 & 20.1 & 0 & 0 & 0.4 & 0.4 & $T$ & 31 & 63 \\
\hline $04 / \mathrm{Dec} / 2004$ & 6.1 & -4.1 & 1 & 17 & 0 & 1.4 & 0 & 1.4 & 0 & 24 & 63 \\
\hline $05 / \mathrm{Dec} / 2004$ & 4.3 & -3.9 & 0.2 & 17.8 & 0 & 0 & 0 & 0 & 0 & 31 & 44 \\
\hline $06 / \mathrm{Dec} / 2004$ & -1.5 & -4.7 & -3.1 & 21.1 & 0 & $T$ & 3 & 3 & 0 & 7 & 37 \\
\hline $07 / \mathrm{Dec} / 2004$ & 11.9 & -2.8 & 4.6 & 13.4 & 0 & 12.4 & $\mathrm{~T}$ & 12.4 & 2 & 23 & 72 \\
\hline $08 / \mathrm{Dec} / 2004$ & 7.3 & 1.6 & 4.5 & 13.5 & 0 & 0 & 0 & 0 & 0 & 27 & 67 \\
\hline $09 / \mathrm{Dec} / 2004$ & 5.8 & 2.8 & 4.3 & 13.7 & 0 & 0 & 0 & 0 & 0 & & $<31$ \\
\hline $10 / \mathrm{Dec} / 2004$ & 3.1 & 1.3 & 2.2 & 15.8 & 0 & 9.8 & 0 & 9.8 & 0 & 6 & 33 \\
\hline $11 / \mathrm{Dec} / 2004$ & 1.3 & -1 & 0.2 & 17.8 & 0 & 0.6 & 2 & 2.6 & $T$ & 32 & 37 \\
\hline 12/Dec/2004 & 2.7 & -1.2 & 0.8 & 17.2 & 0 & 1.4 & 3 & 4.4 & 2 & 19 & 33 \\
\hline 13/Dec/2004 & 2.6 & -9 & -3.2 & 21.2 & 0 & 0 & $T$ & $T$ & $T$ & 34 & 56 \\
\hline
\end{tabular}




\begin{tabular}{|c|c|c|c|c|c|c|c|c|c|c|c|}
\hline 14/Dec/2004 & -4.1 & -10.2 & -7.2 & 25.2 & 0 & 0 & 0.4 & 0.4 & $T$ & 31 & 48 \\
\hline 15/Dec/2004 & 0.9 & -5.6 & -2.4 & 20.4 & 0 & 0 & $T$ & $T$ & $T$ & 25 & 41 \\
\hline $16 / \mathrm{Dec} / 2004$ & 4.9 & -2.8 & 1.1 & 16.9 & 0 & $T$ & 1.4 & 1.4 & 0 & 22 & 59 \\
\hline $17 / \mathrm{Dec} / 2004$ & -2.7 & -8.8 & -5.8 & 23.8 & 0 & 0 & $T$ & $\mathrm{~T}$ & 1 & 28 & 50 \\
\hline 18/Dec/2004 & 3.4 & -5.8 & -1.2 & 19.2 & 0 & $T$ & $\mathrm{~T}$ & $T$ & 1 & 22 & 48 \\
\hline 19/Dec/2004 & 1.5 & -23.5 & -11 & 29 & 0 & $T$ & 0.2 & 0.2 & $T$ & 33 & 61 \\
\hline 20/Dec/2004 & -7.4 & -24.3 & -15.9 & 33.9 & 0 & 0 & 2.6 & 2 & $T$ & 15 & 37 \\
\hline 21/Dec/2004 & 2.5 & -7.6 & -2.6 & 20.6 & 0 & 0 & 0 & 0 & 3 & 24 & 37 \\
\hline 22/Dec/2004 & 1 & -4.2 & -1.6 & 19.6 & 0 & 0 & 3.4 & 4 & 1 & & $<31$ \\
\hline 23/Dec/2004 & -1.5 & -10.4 & -6 & 24 & 0 & 4.2 & 15 & 19.2 & 15 & 32 & 52 \\
\hline 24/Dec/2004 & -7.3 & -16.2 & -11.8 & 29.8 & 0 & 0 & 0 & 0 & 18 & 27 & 39 \\
\hline 25/Dec/2004 & -6.4 & -17.7 & -12.1 & 30.1 & 0 & 0 & 1.2 & 1 & 16 & & $<31$ \\
\hline 26/Dec/2004 & -8.1 & -15 & -11.6 & 29.6 & 0 & 0 & 1.4 & 1.2 & 17 & 2 & 35 \\
\hline $27 / \mathrm{Dec} / 2004$ & -8.4 & -17.8 & -13.1 & 31.1 & 0 & 0 & 0 & 0 & 18 & 34 & 35 \\
\hline $28 / \mathrm{Dec} / 2004$ & -0.8 & -14.2 & -7.5 & 25.5 & 0 & 0 & 0.4 & 0.4 & 18 & & $<31$ \\
\hline 29/Dec/2004 & 1.8 & -0.9 & 0.5 & 17.5 & 0 & $T$ & 0 & $T$ & 18 & & $<31$ \\
\hline $30 / \mathrm{Dec} / 2004$ & 4.2 & -1.6 & 1.3 & 16.7 & 0 & 7.8 & 0 & 7.8 & 17 & & $<31$ \\
\hline 31/Dec/2004 & 9.9 & 3.6 & 6.8 & 11.2 & 0 & 6.6 & 0 & 6.6 & 8 & 24 & 63 \\
\hline $01 / \operatorname{Jan} / 2005$ & 4.2 & -1.7 & 1.3 & 16.7 & 0 & 0 & 0 & 0 & $T$ & 10 & 41 \\
\hline $02 / \operatorname{Jan} / 2005$ & 6.4 & -1.5 & 2.5 & 15.5 & 0 & 16.4 & 0 & 16.4 & $T$ & 10 & 48 \\
\hline $03 / \operatorname{Jan} / 2005$ & 3.7 & 0.5 & 2.1 & 15.9 & 0 & 0.2 & 0.8 & 1 & 0 & & $<31$ \\
\hline $04 / \operatorname{Jan} / 2005$ & 1.6 & -1.9 & -0.2 & 18.2 & 0 & 0 & 0.8 & 0.8 & $T$ & & $<31$ \\
\hline $05 / \operatorname{Jan} / 2005$ & -0.7 & -6.7 & -3.7 & 21.7 & 0 & 0 & 0.4 & 0.4 & $T$ & 4 & 33 \\
\hline $06 / \operatorname{Jan} / 2005$ & -0.8 & -8 & -4.4 & 22.4 & 0 & 0.2 & 3.2 & 7.8 & $T$ & 27 & 61 \\
\hline $07 / \mathrm{Jan} / 2005$ & -0.9 & -5.1 & -3 & 21 & 0 & 0 & 0 & 0 & 3 & & $<31$ \\
\hline $08 / \operatorname{Jan} / 2005$ & 0.3 & -2.4 & -1.1 & 19.1 & 0 & 0 & 0.6 & 0.6 & 3 & & $<31$ \\
\hline $09 / \operatorname{san} / 2005$ & 1.6 & -2 & -0.2 & 18.2 & 0 & 0 & 0.4 & 0.4 & 3 & & $<31$ \\
\hline $10 / \operatorname{Jan} / 2005$ & 2.7 & -2.2 & 0.3 & 17.7 & 0 & 1.2 & 0 & 1.2 & 1 & 28 & 57 \\
\hline $11 / \operatorname{Jan} / 2005$ & -1.5 & -3.9 & -2.7 & 20.7 & 0 & 0 & $\mathrm{~T}$ & $\mathrm{~T}$ & 1 & 8 & 37 \\
\hline $12 / \operatorname{Jan} / 2005$ & 5.8 & -3.1 & 1.4 & 16.6 & 0 & 12.4 & $\mathrm{~T}$ & 12.4 & 1 & & $<31$ \\
\hline $13 / \operatorname{Jan} / 2005$ & 17.6 & 0.3 & 9 & 9 & 0 & 7.4 & 1.8 & 10.2 & $T$ & 35 & 57 \\
\hline $14 / \mathrm{Jan} / 2005$ & 1.1 & -10.3 & -4.6 & 22.6 & 0 & 0 & $T$ & $\mathrm{~T}$ & 1 & 32 & 52 \\
\hline $15 / \operatorname{Jan} / 2005$ & -6.4 & -11.8 & -9.1 & 27.1 & 0 & 0 & 0 & 0 & 1 & 24 & 37 \\
\hline $16 / \mathrm{Jan} / 2005$ & -7.5 & -11.1 & -9.3 & 27.3 & 0 & 0 & 0.6 & 0.6 & 1 & & $<31$ \\
\hline $17 / \operatorname{Jan} / 2005$ & -8.2 & -18.8 & -13.5 & 31.5 & 0 & 0 & 0.4 & 0.4 & 2 & 36 & 50 \\
\hline $18 / \operatorname{Jan} / 2005$ & -7.7 & -23.5 & -15.6 & 33.6 & 0 & 0 & 0 & 0 & 2 & 18 & 35 \\
\hline $19 / \operatorname{Jan} / 2005$ & -2.2 & -8.7 & -5.5 & 23.5 & 0 & 0 & 5.6 & 4.6 & 3 & 34 & 56 \\
\hline $20 / \operatorname{Jan} / 2005$ & -8.7 & -20.1 & -14.4 & 32.4 & 0 & 0 & $\mathrm{~T}$ & $T$ & 6 & 34 & 46 \\
\hline $21 / \operatorname{Jan} / 2005$ & -16.4 & -24.2 & -20.3 & 38.3 & 0 & 0 & $T$ & $\mathrm{~T}$ & 6 & & $<31$ \\
\hline $22 / \operatorname{Jan} / 2005$ & -15.2 & $\begin{array}{l}-18.8 \\
\end{array}$ & -17 & 35 & 0 & 0 & 9.6 & 6.2 & 8 & 2 & 61 \\
\hline $23 / \operatorname{Jan} / 2005$ & -13.2 & -21.4 & -17.3 & 35.3 & 0 & 0 & 0 & 0 & 11 & 35 & 57 \\
\hline $24 / \mathrm{Jan} / 2005$ & -3.8 & -17.4 & -10.6 & 28.6 & 0 & 0 & 1.2 & 0.6 & 9 & 24 & 37 \\
\hline $25 / \operatorname{Jan} / 2005$ & -4.4 & -10.4 & -7.4 & 25.4 & 0 & 0 & 7.8 & 6.8 & 11 & & $<31$ \\
\hline $26 / \mathrm{Jan} / 2005$ & -8.4 & -18.9 & -13.7 & 31.7 & 0 & 0 & $T$ & $T$ & 18 & 36 & 37 \\
\hline $27 / \operatorname{Jan} / 2005$ & -14.6 & -22.7 & -18.7 & 36.7 & 0 & 0 & 0 & 0 & 16 & & $<31$ \\
\hline $28 / \operatorname{Jan} / 2005$ & -7.4 & -21.9 & -14.7 & 32.7 & 0 & 0 & 0 & 0 & 15 & & $<31$ \\
\hline $29 / \operatorname{Jan} / 2005$ & -2.3 & -17.2 & -9.8 & 27.8 & 0 & 0 & 0 & 0 & 15 & & $<31$ \\
\hline $30 / \operatorname{Jan} / 2005$ & 0.2 & -9.9 & -4.9 & 22.9 & 0 & 0 & 0 & 0 & 13 & & $<31$ \\
\hline $31 / \operatorname{Jan} / 2005$ & -0.7 & -13 & -6.9 & 24.9 & 0 & 0 & 0 & 0 & 12 & & $<31$ \\
\hline $01 / \mathrm{Feb} / 2005$ & 0.4 & -11.8 & -5.7 & 23.7 & 0 & 0 & 0 & 0 & 12 & & $<31$ \\
\hline $02 / \mathrm{Feb} / 2005$ & 1 & -12.8 & -5.9 & 23.9 & 0 & 0 & 0 & 0 & 11 & & $<31$ \\
\hline $03 / \mathrm{Feb} / 2005$ & 2.5 & -5.6 & -1.6 & 19.6 & 0 & 0 & 0 & 0 & 10 & & $<31$ \\
\hline $04 / \mathrm{Feb} / 2005$ & 5.7 & -6.9 & -0.6 & 18.6 & 0 & 0 & 0 & 0 & 8 & & $<31$ \\
\hline $05 / \mathrm{Feb} / 2005$ & 3.7 & -4.8 & -0.6 & 18.6 & 0 & 0 & 0 & 0 & 5 & & $<31$ \\
\hline $06 / \mathrm{Feb} / 2005$ & 3.3 & -5.3 & -1 & 19 & 0 & 0 & 0 & 0 & 4 & & $<31$ \\
\hline
\end{tabular}




\begin{tabular}{|c|c|c|c|c|c|c|c|c|c|c|c|}
\hline $07 / \mathrm{Feb} / 2005$ & 4.8 & -0.3 & 2.3 & 15.7 & 0 & 3 & 0 & 3 & 1 & & $<31$ \\
\hline $08 / \mathrm{Feb} / 2005$ & 5.2 & -3 & 1.1 & 16.9 & 0 & 8 & 0 & 8 & $T$ & 34 & 35 \\
\hline $09 / \mathrm{Feb} / 2005$ & -2.8 & -5.4 & -4.1 & 22.1 & 0 & 0 & 6.2 & 6.6 & $T$ & & $<31$ \\
\hline $10 / \mathrm{Feb} / 2005$ & -3.4 & -7.5 & -5.5 & 23.5 & 0 & 0 & 0.8 & 0.4 & 7 & 34 & 48 \\
\hline $11 /$ Feb/2005 & -0.4 & -9.7 & -5.1 & 23.1 & 0 & 0 & $T$ & $T$ & 6 & 28 & 41 \\
\hline $12 / \mathrm{Feb} / 2005$ & 3.7 & -5.9 & -1.1 & 19.1 & 0 & 0 & $\mathrm{~T}$ & $\mathrm{~T}$ & 5 & 31 & 63 \\
\hline $13 / \mathrm{Feb} / 2005$ & -2.1 & -10.4 & -6.3 & 24.3 & 0 & 0 & 0 & 0 & $T$ & 11 & 35 \\
\hline $14 / \mathrm{Feb} / 2005$ & 5.5 & -2.1 & 1.7 & 16.3 & 0 & 15.6 & 0.2 & 15.8 & $\mathrm{~T}$ & 26 & 52 \\
\hline $15 / \mathrm{Feb} / 2005$ & 7.3 & 0.9 & 4.1 & 13.9 & 0 & 16 & 0 & 16 & $\mathrm{~T}$ & 27 & 46 \\
\hline $16 / \mathrm{Feb} / 2005$ & 1.1 & -6.5 & -2.7 & 20.7 & 0 & 0.4 & 4 & 4.4 & 3 & 30 & 39 \\
\hline $17 / \mathrm{Feb} / 2005$ & -1.5 & -8.6 & -5.1 & 23.1 & 0 & 0 & 0.6 & 0.4 & 2 & 26 & 50 \\
\hline $18 / \mathrm{Feb} / 2005$ & -8.5 & -13.8 & -11.2 & 29.2 & 0 & 0 & 0 & 0 & 2 & 32 & 46 \\
\hline $19 / \mathrm{Feb} / 2005$ & -2.2 & -11.8 & -7 & 25 & 0 & 0 & $T$ & $\mathrm{~T}$ & 2 & 25 & 52 \\
\hline $20 / \mathrm{Feb} / 2005$ & -1.9 & -10.9 & -6.4 & 24.4 & 0 & 0 & 7.8 & 7.8 & 2 & 21 & 52 \\
\hline $21 / \mathrm{Feb} / 2005$ & 1.5 & -5.4 & -2 & 20 & 0 & $T$ & 3.4 & 3.4 & 13 & 10 & 39 \\
\hline $22 / \mathrm{Feb} / 2005$ & 0.6 & -8.9 & -4.2 & 22.2 & 0 & 0 & 0.6 & 0.6 & 12 & & $<31$ \\
\hline $23 / \mathrm{Feb} / 2005$ & -3.6 & -13.1 & -8.4 & 26.4 & 0 & 0 & 0 & 0 & 11 & & $<31$ \\
\hline $24 / \mathrm{Feb} / 2005$ & -5.5 & -15.5 & -10.5 & 28.5 & 0 & 0 & $\mathrm{~T}$ & $T$ & 11 & 8 & 35 \\
\hline $25 / \mathrm{Feb} / 2005$ & -3.4 & -16.4 & -9.9 & 27.9 & 0 & 0 & 3.8 & 3.2 & 11 & & $<31$ \\
\hline $26 / \mathrm{Feb} / 2005$ & -3.4 & -12.5 & -8 & 26 & 0 & 0 & 0.2 & 0.2 & 15 & 31 & 46 \\
\hline $27 / \mathrm{Feb} / 2005$ & -2.8 & -13.8 & -8.3 & 26.3 & 0 & 0 & $T$ & $T$ & 15 & & $<31$ \\
\hline $28 / \mathrm{Feb} / 2005$ & 2 & -2.8 & -0.4 & 18.4 & 0 & 0 & 5.8 & 5.8 & 15 & 10 & 39 \\
\hline $01 / \mathrm{Mar} / 2005$ & -1.4 & -6.1 & -3.8 & 21.8 & 0 & 0 & 6.6 & 5.8 & 23 & 10 & 44 \\
\hline $02 / \mathrm{Mar} / 2005$ & -5.1 & -8.5 & -6.8 & 24.8 & 0 & 0 & 1.8 & 1.4 & 26 & 31 & 52 \\
\hline 03/Mar/2005 & -4.4 & -12.3 & -8.4 & 26.4 & 0 & 0 & $T$ & $T$ & 27 & 31 & 41 \\
\hline $04 / \mathrm{Mar} / 2005$ & -0.9 & -9.4 & -5.2 & 23.2 & 0 & 0 & 0 & 0 & 27 & & $<31$ \\
\hline $05 / \mathrm{Mar} / 2005$ & 2.8 & -11.8 & -4.5 & 22.5 & 0 & 0 & 0 & 0 & 26 & & $<31$ \\
\hline $06 / \mathrm{Mar} / 2005$ & 4.6 & -2.6 & 1 & 17 & 0 & 0 & $T$ & $T$ & 23 & 25 & 59 \\
\hline $07 / \mathrm{Mar} / 2005$ & 6.8 & -10.5 & -1.9 & 19.9 & 0 & 5 & $T$ & 5 & 14 & 34 & 67 \\
\hline $08 / \mathrm{Mar} / 2005$ & -8.4 & -14.2 & -11.3 & 29.3 & 0 & 0 & 0 & 0 & 7 & 32 & 52 \\
\hline 09/Mar/2005 & -5.7 & -13.8 & -9.8 & 27.8 & 0 & 0 & 1.8 & 2.2 & 7 & 28 & 54 \\
\hline 10/Mar/2005 & -2.7 & -12.1 & -7.4 & 25.4 & 0 & 0 & 0.2 & 0.2 & 9 & 27 & 33 \\
\hline 11/Mar/2005 & 0.6 & -6.5 & -3 & 21 & 0 & 0 & 2 & 1.6 & 10 & & $<31$ \\
\hline 12/Mar/2005 & -0.7 & -9.3 & -5 & 23 & 0 & 0 & 3.4 & 3 & 11 & & $<31$ \\
\hline 13/Mar/2005 & -2.1 & -9.7 & -5.9 & 23.9 & 0 & 0 & $T$ & $T$ & 13 & 30 & 33 \\
\hline 14/Mar/2005 & -0.3 & -10.5 & -5.4 & 23.4 & 0 & 0 & 0 & 0 & 10 & & $<31$ \\
\hline 15/Mar/2005 & 2.1 & -7.9 & -2.9 & 20.9 & 0 & 0 & 0 & 0 & 8 & 28 & 33 \\
\hline 16/Mar/2005 & 2.5 & -6.4 & -2 & 20 & 0 & 0 & 0 & 0 & 5 & & $<31$ \\
\hline 17/Mar/2005 & 2.9 & -2.3 & 0.3 & 17.7 & 0 & 0 & 1.2 & 0.8 & 5 & & $<31$ \\
\hline 18/Mar/2005 & 2.3 & -4.9 & -1.3 & 19.3 & 0 & 0 & 0 & 0 & 4 & & $<31$ \\
\hline 19/Mar/2005 & 3 & -4.3 & -0.7 & 18.7 & 0 & 0 & $T$ & $T$ & 2 & 9 & 48 \\
\hline $20 / \mathrm{Mar} / 2005$ & 1.9 & -1.3 & 0.3 & 17.7 & 0 & 0 & 3.4 & 3.2 & 1 & 10 & 41 \\
\hline 21/Mar/2005 & 6.2 & -2.1 & 2.1 & 15.9 & 0 & 0 & 0.6 & 0.6 & 5 & & $<31$ \\
\hline $22 / \mathrm{Mar} / 2005$ & 6.9 & -3.9 & 1.5 & 16.5 & 0 & 0 & 0 & 0 & 1 & & $<31$ \\
\hline 23/Mar/2005 & 1.9 & -2 & -0.1 & 18.1 & 0 & 0 & 4 & 3.8 & $\mathrm{~T}$ & 8 & 44 \\
\hline 24/Mar/2005 & 4.9 & -1.9 & 1.5 & 16.5 & 0 & 0 & 0.6 & 0.6 & 4 & & $<31$ \\
\hline 25/Mar/2005 & 4.4 & -4.7 & -0.2 & 18.2 & 0 & 0 & 0 & 0 & 1 & & $<31$ \\
\hline 26/Mar/2005 & 5.7 & -5.9 & -0.1 & 18.1 & 0 & 0 & 0 & 0 & $\mathrm{~T}$ & & $<31$ \\
\hline 27/Mar/2005 & 7.3 & -4.3 & 1.5 & 16.5 & 0 & 0 & 0 & 0 & $\mathrm{~T}$ & & $<31$ \\
\hline 28/Mar/2005 & 6.9 & -0.3 & 3.3 & 14.7 & 0 & $T$ & 0 & $T$ & $\mathrm{~T}$ & 3 & 33 \\
\hline 29/Mar/2005 & 12.9 & 0.8 & 6.9 & 11.1 & 0 & 0 & 0 & 0 & 0 & & $<31$ \\
\hline 30/Mar/2005 & 11.6 & 0.7 & 6.2 & 11.8 & 0 & 0 & 0 & 0 & 0 & 9 & 41 \\
\hline $31 / \mathrm{Mar} / 2005$ & 15.3 & 5.7 & 10.5 & 7.5 & 0 & 4.6 & 0 & 4.6 & 0 & 26 & 57 \\
\hline $01 / \mathrm{Apr} / 2005$ & 13 & 5.4 & 9.2 & 8.8 & 0 & 0 & 0 & 0 & 0 & 27 & 50 \\
\hline $02 / \mathrm{Apr} / 2005$ & 6.4 & 0.3 & 3.4 & 14.6 & 0 & 13.6 & 7.6 & 21.4 & 0 & 36 & 65 \\
\hline
\end{tabular}




\begin{tabular}{|c|c|c|c|c|c|c|c|c|c|c|c|}
\hline 03/Apr/2005 & 3.1 & 0.2 & 1.7 & 16.3 & 0 & 4.2 & 8.6 & 12.8 & 3 & 34 & 72 \\
\hline 04/Apr/2005 & 11.1 & 1.1 & 6.1 & 11.9 & 0 & 0 & 0 & 0 & 0 & 32 & 54 \\
\hline 05/Apr/2005 & 12.9 & 0.2 & 6.6 & 11.4 & 0 & 0 & 0 & 0 & 0 & & $<31$ \\
\hline 06/Apr/2005 & 13.5 & 5.8 & 9.7 & 8.3 & 0 & 0 & 0 & 0 & 0 & 11 & 32 \\
\hline 07/Apr/2005 & 11.4 & 2.7 & 7.1 & 10.9 & 0 & 2.4 & 0 & 2.4 & 0 & 34 & 39 \\
\hline 08/Apr/2005 & 14.7 & 0.8 & 7.8 & 10.2 & 0 & 0 & 0 & 0 & 0 & 33 & 33 \\
\hline 09/Apr/2005 & 14.2 & 0.4 & 7.3 & 10.7 & 0 & 0 & 0 & 0 & 0 & & $<31$ \\
\hline 10/Apr/2005 & 18.8 & 2.6 & 10.7 & 7.3 & 0 & 0 & 0 & 0 & 0 & 7 & 33 \\
\hline 11/Apr/2005 & 9.3 & 1.3 & 5.3 & 12.7 & 0 & 0 & 0 & 0 & 0 & 15 & 32 \\
\hline 12/Apr/2005 & 9.7 & 2 & 5.9 & 12.1 & 0 & 0 & 0 & 0 & 0 & 10 & 44 \\
\hline 13/Apr/2005 & 13.1 & 0.2 & 6.7 & 11.3 & 0 & 0 & 0 & 0 & 0 & & $<31$ \\
\hline 14/Apr/2005 & 14.3 & 4.2 & 9.3 & 8.7 & 0 & 0 & 0 & 0 & 0 & & $<31$ \\
\hline 15/Apr/2005 & 11.5 & 3.5 & 7.5 & 10.5 & 0 & 0 & 0 & 0 & 0 & & $<31$ \\
\hline 16/Apr/2005 & 19.9 & 0.8 & 10.4 & 7.6 & 0 & 0 & 0 & 0 & 0 & 18 & 33 \\
\hline 17/Apr/2005 & 20.9 & 6.8 & 13.9 & 4.1 & 0 & 0 & 0 & 0 & 0 & & $<31$ \\
\hline 18/Apr/2005 & 19.5 & 7.4 & 13.5 & 4.5 & 0 & 0 & 0 & 0 & 0 & & $<31$ \\
\hline 19/Apr/2005 & 27.5 & 7.2 & 17.4 & 0.6 & 0 & 0 & 0 & 0 & 0 & 24 & 33 \\
\hline 20/Apr/2005 & 17.9 & 3 & 10.5 & 7.5 & 0 & 4.8 & 0 & 4.8 & 0 & 35 & 57 \\
\hline 21/Apr/2005 & 10.8 & 1.5 & 6.2 & 11.8 & 0 & 0 & 0 & 0 & 0 & & $<31$ \\
\hline 22/Apr/2005 & 12.7 & 1.1 & 6.9 & 11.1 & 0 & 6 & 0 & 6 & 0 & 11 & 33 \\
\hline 23/Apr/2005 & 7.8 & 4.1 & 6 & 12 & 0 & 22 & 0 & 22 & 0 & 5 & 44 \\
\hline 24/Apr/2005 & 5.7 & 1.6 & 3.7 & 14.3 & 0 & 13.2 & 0 & 13.2 & 0 & & $<31$ \\
\hline 25/Apr/2005 & 7.2 & 1.6 & 4.4 & 13.6 & 0 & 0.4 & 0 & 0.4 & 0 & 27 & 46 \\
\hline 26/Apr/2005 & 15.1 & 3.9 & 9.5 & 8.5 & 0 & 3.6 & 0 & 3.6 & 0 & 20 & 33 \\
\hline 27/Apr/2005 & 13.1 & 6.6 & 9.9 & 8.1 & 0 & 5 & 0 & 5 & 0 & 27 & 48 \\
\hline 28/Apr/2005 & 9.5 & 2 & 5.8 & 12.2 & 0 & 4.8 & 0 & 4.8 & 0 & 28 & 46 \\
\hline 29/Apr/2005 & 11.7 & 0.2 & 6 & 12 & 0 & 0 & 0 & 0 & 0 & & $<31$ \\
\hline 30/Apr/2005 & 6.8 & 2.7 & 4.8 & 13.2 & 0 & 1.2 & 0 & 1.2 & 0 & 1 & 33 \\
\hline
\end{tabular}




\begin{tabular}{|c|c|c|c|c|c|c|c|c|c|c|c|}
\hline \multicolumn{12}{|c|}{ Daily Data Report for Winter 2005-2006 } \\
\hline \multicolumn{3}{|c|}{ Environment Canada } & \multicolumn{5}{|c|}{$\begin{array}{l}\text { National Climate Data and Information } \\
\text { Archive }\end{array}$} & \multicolumn{4}{|c|}{ www.climate.weatheroffice.gc.ca } \\
\hline Day & $\begin{array}{l}\text { Max } \\
\text { Temp }\end{array}$ & $\underset{\text { Temp }}{\operatorname{Min}}$ & $\begin{array}{l}\text { Mean } \\
\text { Temp }\end{array}$ & $\begin{array}{c}\text { Heat } \\
\text { Deg } \\
\text { Days } \\
\end{array}$ & \begin{tabular}{|l|} 
Cool \\
Deg \\
Days \\
\end{tabular} & $\begin{array}{l}\text { Total } \\
\text { Rain }\end{array}$ & $\begin{array}{l}\text { Total } \\
\text { Snow }\end{array}$ & $\begin{array}{l}\text { Total } \\
\text { Precip }\end{array}$ & $\begin{array}{l}\text { Snow } \\
\text { on } \\
\text { Grnd }\end{array}$ & $\begin{array}{l}\text { Dir of } \\
\text { Max } \\
\text { Gust }\end{array}$ & $\begin{array}{l}\text { Spd of } \\
\text { Max } \\
\text { Gust }\end{array}$ \\
\hline & ${ }^{\circ} \mathrm{C}$ & ${ }^{\circ} \mathrm{C}$ & ${ }^{\circ} \mathrm{C}$ & ${ }^{\circ} \mathrm{C}$ & ${ }^{\circ} \mathrm{C}$ & $\mathrm{mm}$ & $\mathrm{cm}$ & $\mathbf{m m}$ & $\mathrm{cm}$ & 10's Deg & $\mathrm{km} / \mathrm{h}$ \\
\hline $31 /$ Oct $/ 2005$ & 13.7 & 7.8 & 9.9 & 7.2 & 0 & 2.4 & 0 & 2.4 & 0 & 26 & 32 \\
\hline 01/Nov/2005 & 12.8 & 4.2 & 8.5 & 9.5 & 0 & 0.8 & 0 & 0.8 & 0 & 28 & 41 \\
\hline $02 / \mathrm{Nov} / 2005$ & 12.5 & 2 & 7.3 & 10.7 & 0 & 0 & 0 & 0 & 0 & & $<31$ \\
\hline $03 /$ Nov/2005 & 19.1 & 8.8 & 14 & 4 & 0 & 0 & 0 & 0 & 0 & 26 & 57 \\
\hline $04 /$ Nov/2005 & 18.3 & 8.9 & 13.6 & 4.4 & 0 & 0 & 0 & 0 & 0 & 23 & 44 \\
\hline 05/Nov/2005 & 12.8 & 7.8 & 10.3 & 7.7 & 0 & 4.8 & 0 & 4.8 & 0 & & $<31$ \\
\hline 06/Nov/2005 & 17.7 & 7 & 12.4 & 5.6 & 0 & 5.4 & 0 & 5.4 & 0 & 26 & 89 \\
\hline 07/Nov/2005 & 12.8 & 5.8 & 9.3 & 8.7 & 0 & 0 & 0 & 0 & 0 & 28 & 50 \\
\hline $08 /$ Nov/2005 & 11.6 & 5.6 & 8.6 & 9.4 & 0 & 0 & 0 & 0 & 0 & & $<31$ \\
\hline $09 /$ Nov/2005 & 13.1 & 5.2 & 9.2 & 8.8 & 0 & 20.8 & 0 & 20.8 & 0 & 29 & 59 \\
\hline $10 /$ Nov/2005 & 6 & 2.8 & 4.4 & 13.6 & 0 & 0.4 & $T$ & 0.4 & 0 & 31 & 80 \\
\hline 11/Nov/2005 & 8.9 & 2.6 & 5.8 & 12.2 & 0 & 0 & 0 & 0 & 0 & 27 & 35 \\
\hline $12 /$ Nov/2005 & 14.5 & 2.7 & 8.6 & 9.4 & 0 & 0 & 0 & 0 & 0 & & $<31$ \\
\hline 13/Nov/2005 & 16.9 & 7.9 & 12.4 & 5.6 & 0 & $T$ & 0 & $T$ & 0 & 26 & 76 \\
\hline $14 /$ Nov/2005 & 8.9 & 4 & 6.5 & 11.5 & 0 & 0 & 0 & 0 & 0 & 27 & 61 \\
\hline 15/Nov/2005 & 9.3 & 5.5 & 7.4 & 10.6 & 0 & 28.4 & 0 & 28.4 & 0 & 10 & 56 \\
\hline $16 /$ Nov/2005 & 16.5 & 0.2 & 8.4 & 9.6 & 0 & 1.6 & $T$ & 1.6 & 0 & 24 & 83 \\
\hline $17 /$ Nov/2005 & 3 & -5.5 & -1.3 & 19.3 & 0 & 0 & $\mathrm{~T}$ & $T$ & 0 & 32 & 59 \\
\hline 18/Nov/2005 & -0.7 & -5.9 & -3.3 & 21.3 & 0 & 0 & 0.8 & 0.6 & $\mathrm{~T}$ & 25 & 32 \\
\hline 19/Nov/2005 & 8.4 & -0.8 & 3.8 & 14.2 & 0 & 0 & 0 & 0 & 1 & 22 & 46 \\
\hline 20/Nov/2005 & 10.7 & 1.1 & 5.9 & 12.1 & 0 & 0 & 0 & 0 & 0 & 25 & 33 \\
\hline $21 /$ Nov/2005 & 6.4 & 2.5 & 4.5 & 13.5 & 0 & $T$ & 0 & $T$ & 0 & 25 & 32 \\
\hline $22 /$ Nov/2005 & 4.4 & -6.9 & -1.3 & 19.3 & 0 & 0 & 0.2 & 0.2 & 0 & 33 & 65 \\
\hline 23/Nov/2005 & -0.8 & -9.6 & -5.2 & 23.2 & 0 & 0 & 4 & 3.6 & 1 & 14 & 32 \\
\hline $24 /$ Nov/2005 & 0.3 & -12 & -5.9 & 23.9 & 0 & 0 & 5.2 & 5.4 & 6 & 24 & 78 \\
\hline $25 /$ Nov/2005 & -1.8 & -13.3 & -7.6 & 25.6 & 0 & 0 & 0 & 0 & 7 & 27 & 48 \\
\hline $26 /$ Nov/2005 & -2.4 & -5.6 & -4 & 22 & 0 & 0 & 2.2 & 1 & 6 & & $<31$ \\
\hline $27 /$ Nov/2005 & 3.6 & -7.4 & -1.9 & 19.9 & 0 & 1.4 & 0 & 1.4 & 6 & & $<31$ \\
\hline 28/Nov/2005 & 14.5 & 3.5 & 9 & 9 & 0 & 7.6 & 0 & 7.6 & $\mathbf{T}$ & 12 & 32 \\
\hline 29/Nov/2005 & 16.8 & 3.4 & 10.1 & 7.9 & 0 & 20.2 & 0 & 20.2 & 0 & 27 & 44 \\
\hline $30 /$ Nov/2005 & 3.5 & 0.7 & 2.1 & 15.9 & 0 & 0 & $T$ & $\mathrm{~T}$ & 0 & 26 & 37 \\
\hline 01/Dec/2005 & 2.4 & -0.3 & 1.1 & 16.9 & 0 & 0 & 1.4 & 1.4 & 0 & & $<31$ \\
\hline $02 / \mathrm{Dec} / 2005$ & 0 & -4.6 & -2.3 & 20.3 & 0 & 0 & 1.6 & 1.2 & 2 & 30 & 67 \\
\hline 03/Dec/2005 & 0.1 & -5.4 & -2.7 & 20.7 & 0 & 0 & 0.2 & 0.2 & 2 & 28 & 48 \\
\hline 04/Dec/2005 & -0.6 & -6 & -3.3 & 21.3 & 0 & 0 & 1.6 & 1.6 & 2 & 26 & 44 \\
\hline 05/Dec/2005 & -2.8 & -6.9 & -4.9 & 22.9 & 0 & 0 & $\mathrm{~T}$ & $T$ & 1 & 27 & 48 \\
\hline $06 / \mathrm{Dec} / 2005$ & -3.8 & -8.2 & -6 & 24 & 0 & 0 & $\mathrm{~T}$ & $T$ & 1 & 27 & 52 \\
\hline 07/Dec/2005 & -3.9 & -9.9 & -6.9 & 24.9 & 0 & 0 & 0.6 & 0.3 & $\mathrm{~T}$ & 27 & 39 \\
\hline $08 / \mathrm{Dec} / 2005$ & -0.1 & -9.6 & -4.9 & 22.9 & 0 & 0 & $T$ & $\mathrm{~T}$ & $\mathrm{~T}$ & 9 & 35 \\
\hline 09/Dec/2005 & -0.1 & -5.2 & -2.7 & 20.7 & 0 & 0 & 11.6 & 9.6 & 11 & 26 & 50 \\
\hline 10/Dec/2005 & -0.8 & -6.9 & -3.9 & 21.9 & 0 & 0 & 0 & 0 & 12 & 24 & 48 \\
\hline $11 / \mathrm{Dec} / 2005$ & 0.2 & -9.6 & -4.7 & 22.7 & 0 & 0 & 1 & 0.6 & 12 & 32 & 44 \\
\hline 12/Dec/2005 & -9.4 & -14.6 & -12 & 30 & 0 & 0 & 0 & 0 & 13 & 35 & 35 \\
\hline 13/Dec/2005 & -3.7 & -15.2 & -9.5 & 27.5 & 0 & 0 & 1.8 & 0.7 & 11 & & $<31$ \\
\hline 14/Dec/2005 & -3.6 & -10 & -6.8 & 24.8 & 0 & 0 & 0.2 & 0.2 & 10 & 11 & 44 \\
\hline
\end{tabular}




\begin{tabular}{|c|c|c|c|c|c|c|c|c|c|c|c|}
\hline 15/Dec/2005 & 0.2 & -5 & -2.4 & 20.4 & 0 & 0 & 5.4 & 7.3 & 9 & 15 & 37 \\
\hline $16 / \mathrm{Dec} / 2005$ & 0.7 & -3.5 & -1.4 & 19.4 & 0 & 0 & 1.2 & 1.2 & 16 & 25 & 50 \\
\hline 17/Dec/2005 & -2.6 & -5.5 & -4.1 & 22.1 & 0 & 0 & 0 & 0 & 14 & 23 & 35 \\
\hline $18 / \mathrm{Dec} / 2005$ & -3.8 & -9.1 & -6.5 & 24.5 & 0 & 0 & $T$ & $T$ & 14 & & $<31$ \\
\hline 19/Dec/2005 & -4.7 & -10.1 & -7.4 & 25.4 & 0 & 0 & 0 & 0 & 14 & 26 & 57 \\
\hline 20/Dec/2005 & -3.1 & -13.2 & -8.2 & 26.2 & 0 & 0 & 2.6 & 2.4 & 14 & 27 & 56 \\
\hline 21/Dec/2005 & -2.9 & -12 & -7.5 & 25.5 & 0 & 0 & $\mathrm{~T}$ & $\mathbf{T}$ & 16 & 26 & 41 \\
\hline 22/Dec/2005 & 2.3 & -4.6 & -1.2 & 19.2 & 0 & 0 & $T$ & $T$ & 16 & 27 & 65 \\
\hline 23/Dec/2005 & 3 & 1.6 & 2.3 & 15.7 & 0 & 3.6 & 0 & 3.6 & 13 & 24 & 35 \\
\hline 24/Dec/2005 & 3.8 & 1.7 & 2.8 & 15.2 & 0 & 0 & 0 & 0 & 6 & & $<31$ \\
\hline 25/Dec/2005 & 4 & 0.3 & 2.2 & 15.8 & 0 & 6.2 & 8 & 14.2 & 4 & & $<31$ \\
\hline 26/Dec/2005 & 1.1 & -0.8 & 0.2 & 17.8 & 0 & 0.4 & 0.2 & 0.8 & 2 & 34 & 54 \\
\hline 27/Dec/2005 & 1.6 & -4.2 & -1.3 & 19.3 & 0 & 0 & 0 & 0 & 2 & & $<31$ \\
\hline 28/Dec/2005 & 4.4 & 0.9 & 2.7 & 15.3 & 0 & 7 & 0 & 7 & 2 & & $<31$ \\
\hline 29/Dec/2005 & 1.7 & -2.8 & -0.6 & 18.6 & 0 & 2.8 & $T$ & 2.8 & 1 & 34 & 46 \\
\hline $30 / \mathrm{Dec} / 2005$ & -0.2 & -5.5 & -2.9 & 20.9 & 0 & 0 & 0 & 0 & $\mathrm{~T}$ & 36 & 33 \\
\hline $31 / \mathrm{Dec} / 2005$ & -1.9 & -7.1 & -4.5 & 22.5 & 0 & 0 & 4.4 & 3.8 & 1 & 9 & 44 \\
\hline $01 / \operatorname{Jan} / 2006$ & 1.3 & -5.4 & -2.1 & 20.1 & 0 & 0 & $T$ & $\mathrm{~T}$ & 3 & & $<31$ \\
\hline $02 / \mathrm{Jan} / 2006$ & 2.5 & -0.1 & 1.2 & 16.8 & 0 & 0.6 & 0 & 0.6 & 1 & 9 & 48 \\
\hline 03/Jan/2006 & 2.6 & 0.3 & 1.5 & 16.5 & 0 & $\mathrm{~T}$ & 0 & $\mathrm{~T}$ & $\mathrm{~T}$ & 9 & 44 \\
\hline $04 / \mathrm{Jan} / 2006$ & 5.4 & 1.6 & 3.5 & 14.5 & 0 & 3.6 & 0 & 3.6 & $\mathrm{~T}$ & & $<31$ \\
\hline 05/Jan/2006 & 4.2 & -3.5 & 0.4 & 17.6 & 0 & 3.8 & $\mathrm{~T}$ & 3.8 & $T$ & 33 & 46 \\
\hline $06 / \operatorname{Jan} / 2006$ & -3.4 & -9.3 & -6.4 & 24.4 & 0 & 0 & $T$ & $T$ & $\mathrm{~T}$ & 34 & 39 \\
\hline $07 / \operatorname{Jan} / 2006$ & -0.4 & -5.8 & -3.1 & 21.1 & 0 & 0 & 2.6 & 2.6 & $\mathrm{~T}$ & & $<31$ \\
\hline $08 / \mathrm{Jan} / 2006$ & 2.6 & -6.5 & -2 & 20 & 0 & 0 & 0 & 0 & 2 & 10 & 35 \\
\hline $09 / \operatorname{Jan} / 2006$ & 3.1 & 0.6 & 1.9 & 16.1 & 0 & 1 & 0.4 & 1.4 & $\mathrm{~T}$ & 29 & 37 \\
\hline $10 / \operatorname{Jan} / 2006$ & 3.5 & 0.1 & 1.8 & 16.2 & 0 & $\mathrm{~T}$ & 0 & $T$ & $T$ & & $<31$ \\
\hline $11 / \operatorname{Jan} / 2006$ & 8.8 & 1.6 & 5.2 & 12.8 & 0 & 1.4 & 0 & 1.4 & $\mathrm{~T}$ & 22 & 33 \\
\hline $12 / \operatorname{Jan} / 2006$ & 9.5 & 3.3 & 6.4 & 11.6 & 0 & 0 & 0 & 0 & $\mathrm{~T}$ & 25 & 41 \\
\hline $13 / \operatorname{Jan} / 2006$ & 10.1 & 3.1 & 6.6 & 11.4 & 0 & 0.8 & 0 & 0.8 & 0 & & $<31$ \\
\hline $14 / \operatorname{Jan} / 2006$ & 6.5 & -8.3 & -0.9 & 18.9 & 0 & 0.4 & 0.2 & 0.6 & $T$ & 34 & 82 \\
\hline $15 / \operatorname{Jan} / 2006$ & -7.9 & -12.7 & -10.3 & 28.3 & 0 & 0 & 0.2 & 0.2 & $T$ & 34 & 41 \\
\hline $16 / \operatorname{Jan} / 2006$ & -3.9 & -13.1 & -8.5 & 26.5 & 0 & 0 & 0 & 0 & $\mathrm{~T}$ & & $<31$ \\
\hline $17 /$ Jan/2006 & 4.4 & -6 & -0.8 & 18.8 & 0 & 18.6 & 0 & 18.6 & 0 & 10 & 52 \\
\hline $18 / \operatorname{Jan} / 2006$ & 4.7 & -2.8 & 1 & 17 & 0 & 6.2 & 0.6 & 7 & 0 & 27 & 65 \\
\hline $19 / \operatorname{Jan} / 2006$ & 3.8 & -3.4 & 0.2 & 17.8 & 0 & 0 & $T$ & $T$ & $T$ & 25 & 33 \\
\hline $20 / \operatorname{Jan} / 2006$ & 11.4 & 0.6 & 6 & 12 & 0 & 2.4 & 0 & 2.4 & 0 & 32 & 37 \\
\hline $21 / \operatorname{Jan} / 2006$ & 1.1 & -4.4 & -1.7 & 19.7 & 0 & 9.6 & 2.6 & 12.2 & 0 & 33 & 56 \\
\hline $22 / \operatorname{Jan} / 2006$ & 2.8 & -6.2 & -1.7 & 19.7 & 0 & 0 & 0 & 0 & $T$ & & $<31$ \\
\hline $23 / \operatorname{Jan} / 2006$ & 3.6 & -2.8 & 0.4 & 17.6 & 0 & 0 & 0 & 0 & $T$ & 32 & 32 \\
\hline $24 / \operatorname{Jan} / 2006$ & 4.8 & -3.4 & 0.7 & 17.3 & 0 & $\mathrm{~T}$ & 1.2 & 1.2 & 0 & 24 & 56 \\
\hline $25 / \operatorname{Jan} / 2006$ & 1.9 & -7.7 & -2.9 & 20.9 & 0 & $\mathrm{~T}$ & $\mathrm{~T}$ & $\mathrm{~T}$ & 0 & 32 & 67 \\
\hline $26 / \operatorname{Jan} / 2006$ & -3.4 & -12.3 & -7.9 & 25.9 & 0 & 0 & $\mathrm{~T}$ & $\mathrm{~T}$ & $T$ & 33 & 50 \\
\hline $27 / \operatorname{Jan} / 2006$ & 6.6 & -8.6 & -1 & 19 & 0 & 0 & 0 & 0 & 0 & 23 & 35 \\
\hline $28 / \operatorname{Jan} / 2006$ & 10.4 & 1.3 & 5.9 & 12.1 & 0 & 0.2 & 0 & 0.2 & 0 & & $<31$ \\
\hline $29 / \operatorname{Jan} / 2006$ & 8.1 & 2.9 & 5.5 & 12.5 & 0 & 15.8 & 0 & 15.8 & 0 & 10 & 44 \\
\hline $30 / \operatorname{Jan} / 2006$ & 9.1 & 3.1 & 6.1 & 11.9 & 0 & 2.2 & 0 & 2.2 & 0 & 23 & 44 \\
\hline $31 / \operatorname{Jan} / 2006$ & 3.2 & -0.8 & 1.2 & 16.8 & 0 & 0 & $T$ & $T$ & 0 & 27 & 37 \\
\hline $01 / \mathrm{Feb} / 2006$ & 3.1 & -3.1 & 0 & 18 & 0 & 0 & $\mathrm{~T}$ & $T$ & 0 & & $<31$ \\
\hline $02 / \mathrm{Feb} / 2006$ & 6.7 & 0.4 & 3.6 & 14.4 & 0 & 1.6 & 0 & 1.6 & 0 & & $<31$ \\
\hline $03 / \mathrm{Feb} / 2006$ & 5.2 & 1.5 & 3.4 & 14.6 & 0 & 11.4 & 0 & 11.4 & 0 & 27 & 43 \\
\hline $04 / \mathrm{Feb} / 2006$ & 3.9 & 0.5 & 2.2 & 15.8 & 0 & 19.4 & 2 & 22.4 & 0 & 8 & 54 \\
\hline $05 / \mathrm{Feb} / 2006$ & 3.1 & -4.4 & -0.7 & 18.7 & 0 & 2.2 & 1.6 & 3.8 & 0 & 27 & 67 \\
\hline $06 / \mathrm{Feb} / 2006$ & -1.7 & -5.2 & -3.5 & 21.5 & 0 & 0 & 3 & 3 & 1 & 26 & 76 \\
\hline $07 / \mathrm{Feb} / 2006$ & -1.2 & -5.4 & -3.3 & 21.3 & 0 & 0 & $\mathrm{~T}$ & $T$ & 2 & 32 & 35 \\
\hline
\end{tabular}




\begin{tabular}{|c|c|c|c|c|c|c|c|c|c|c|c|}
\hline $08 / \mathrm{Feb} / 2006$ & -5.4 & -10.5 & -8 & 26 & 0 & 0 & $T$ & $T$ & 1 & 36 & 32 \\
\hline $09 / \mathrm{Feb} / 2006$ & -4.4 & -11.1 & -7.8 & 25.8 & 0 & 0 & $T$ & $T$ & $T$ & 31 & 48 \\
\hline $10 / \mathrm{Feb} / 2006$ & -2.8 & -9.1 & -6 & 24 & 0 & 0 & 2.2 & 1.4 & $\mathrm{~T}$ & & $<31$ \\
\hline $11 / \mathrm{Feb} / 2006$ & -2.7 & -9.3 & -6 & 24 & 0 & 0 & $T$ & $T$ & 1 & & $<31$ \\
\hline $12 / \mathrm{Feb} / 2006$ & -3.9 & -13.1 & -8.5 & 26.5 & 0 & 0 & $T$ & $T$ & 1 & 32 & 32 \\
\hline $13 / \mathrm{Feb} / 2006$ & -1.7 & -6.8 & -4.3 & 22.3 & 0 & 0 & $T$ & $T$ & $\mathrm{~T}$ & 27 & 67 \\
\hline $14 / \mathrm{Feb} / 2006$ & 3.3 & -4.9 & -0.8 & 18.8 & 0 & 0 & $T$ & $T$ & $T$ & 25 & 44 \\
\hline $15 /$ Feb/2006 & 6.8 & -0.4 & 3.2 & 14.8 & 0 & 0 & 0 & 0 & $T$ & & $<31$ \\
\hline 16/Feb/2006 & 2.2 & -2.4 & -0.1 & 18.1 & 0 & 13 & 5.4 & 18 & 5 & 32 & 41 \\
\hline $17 / \mathrm{Feb} / 2006$ & 6.8 & -7.6 & -0.4 & 18.4 & 0 & 6.2 & $T$ & 6.2 & 1 & 31 & 91 \\
\hline $18 / \mathrm{Feb} / 2006$ & -7.5 & -14.5 & -11 & 29 & 0 & 0 & 1.2 & 1 & 1 & 30 & 59 \\
\hline 19/Feb/2006 & -6.8 & -13.1 & -10 & 28 & 0 & 0 & 0 & 0 & 1 & 25 & 50 \\
\hline 20/Feb/2006 & -3.1 & -10.4 & -6.8 & 24.8 & 0 & 0 & $T$ & $T$ & 1 & 26 & 52 \\
\hline $21 / \mathrm{Feb} / 2006$ & 1.5 & -4.6 & -1.6 & 19.6 & 0 & 0 & $T$ & $T$ & $T$ & 25 & 56 \\
\hline $22 / \mathrm{Feb} / 2006$ & 7 & -5.1 & 1 & 17 & 0 & 0 & 0 & 0 & $T$ & 22 & 33 \\
\hline $23 / \mathrm{Feb} / 2006$ & 6 & -4.6 & 0.7 & 17.3 & 0 & $T$ & 0.4 & 0.4 & 0 & 32 & 65 \\
\hline $24 / \mathrm{Feb} / 2006$ & -0.6 & -7.6 & $\begin{array}{l}-4.1 \\
\end{array}$ & 22.1 & 0 & 0 & 1.4 & 1.4 & $T$ & 31 & 54 \\
\hline $25 / \mathrm{Feb} / 2006$ & 2 & -8.4 & -3.2 & 21.2 & 0 & 0 & 3.8 & 3.8 & 5 & 30 & 67 \\
\hline $26 / \mathrm{Feb} / 2006$ & -6.8 & -13.8 & -10.3 & 28.3 & 0 & 0 & 0 & 0 & 3 & 36 & 39 \\
\hline $27 / \mathrm{Feb} / 2006$ & -3.5 & -13.8 & -8.7 & 26.7 & 0 & 0 & 0.6 & 0.4 & 3 & 31 & 54 \\
\hline $28 / \mathrm{Feb} / 2006$ & -4.7 & -13.9 & -9.3 & 27.3 & 0 & 0 & $T$ & $T$ & 3 & 27 & 54 \\
\hline $01 / \mathrm{Mar} / 2006$ & -1.7 & -10 & -5.9 & 23.9 & 0 & 0 & 0 & 0 & 2 & 33 & 39 \\
\hline $02 / \mathrm{Mar} / 2006$ & -2.1 & -8.9 & -5.5 & 23.5 & 0 & 0 & 0 & 0 & 1 & 34 & 37 \\
\hline 03/Mar/2006 & -2.4 & -11.1 & -6.8 & 24.8 & 0 & 0 & 0 & 0 & 1 & 35 & 59 \\
\hline $04 / \mathrm{Mar} / 2006$ & 3.4 & -7.3 & -2 & 20 & 0 & 0 & 0 & 0 & $T$ & 33 & 52 \\
\hline $05 / \mathrm{Mar} / 2006$ & 4.6 & -4.8 & -0.1 & 18.1 & 0 & 0 & 0 & 0 & $\mathrm{~T}$ & 36 & 37 \\
\hline $06 / \mathrm{Mar} / 2006$ & 0.6 & -5.8 & -2.6 & 20.6 & 0 & 0 & 0 & 0 & $\mathrm{~T}$ & 35 & 33 \\
\hline $07 / \mathrm{Mar} / 2006$ & 2.6 & -5.7 & -1.6 & 19.6 & 0 & 0 & 0 & 0 & 0 & & $<31$ \\
\hline 08/Mar/2006 & 3.7 & -5.4 & -0.9 & 18.9 & 0 & 0 & 0 & 0 & 0 & & $<31$ \\
\hline $09 / \mathrm{Mar} / 2006$ & 11.5 & 2.7 & 7.1 & 10.9 & 0 & 16.8 & 0 & 16.8 & 0 & 20 & 32 \\
\hline 10/Mar/2006 & 11.4 & 1.1 & 6.3 & 11.7 & 0 & 1.4 & 0 & 1.4 & 0 & 22 & 61 \\
\hline 11/Mar/2006 & 10 & -0.6 & 4.7 & 13.3 & 0 & 0 & 0 & 0 & 0 & & $<31$ \\
\hline 12/Mar/2006 & 16.3 & 2.9 & 9.6 & 8.4 & 0 & 1.8 & 0 & 1.8 & 0 & & $<31$ \\
\hline 13/Mar/2006 & 13.3 & 3.4 & 8.4 & 9.6 & 0 & 21.4 & 0 & 21.4 & 0 & 28 & 56 \\
\hline 14/Mar/2006 & 5 & -1.7 & 1.7 & 16.3 & 0 & 0 & 1 & 0.6 & 0 & 36 & 85 \\
\hline 15/Mar/2006 & 3.3 & -2 & 0.7 & 17.3 & 0 & 0 & $T$ & $T$ & $T$ & 30 & 83 \\
\hline $16 / \mathrm{Mar} / 2006$ & 4.4 & -4.5 & -0.1 & 18.1 & 0 & 0 & 0 & 0 & 0 & 31 & 35 \\
\hline 17/Mar/2006 & 1.6 & -7.1 & -2.8 & 20.8 & 0 & 0 & 0 & 0 & 0 & 33 & 44 \\
\hline 18/Mar/2006 & 0.1 & -6.9 & -3.4 & 21.4 & 0 & 0 & $T$ & $T$ & 0 & 31 & 59 \\
\hline 19/Mar/2006 & 2.7 & -4.8 & -1.1 & 19.1 & 0 & 0 & $\mathrm{~T}$ & $T$ & 0 & 30 & 56 \\
\hline 20/Mar/2006 & -1 & -7 & -4 & 22 & 0 & 0 & 0 & 0 & 0 & 35 & 41 \\
\hline 21/Mar/2006 & 1.8 & -7.8 & -3 & 21 & 0 & 0 & $T$ & $T$ & 0 & 36 & 44 \\
\hline $22 / \mathrm{Mar} / 2006$ & 2 & -2.8 & -0.4 & 18.4 & 0 & 0 & 0.2 & 0.2 & $T$ & 30 & 35 \\
\hline 23/Mar/2006 & 3.4 & -0.4 & 1.5 & 16.5 & 0 & 0 & 0 & 0 & 0 & & $<31$ \\
\hline 24/Mar/2006 & 6.2 & -1.7 & 2.3 & 15.7 & 0 & $T$ & $T$ & $T$ & 0 & & $<31$ \\
\hline 25/Mar/2006 & 4.5 & -0.3 & 2.1 & 15.9 & 0 & 3.2 & 0.2 & 3.4 & 0 & & $<31$ \\
\hline $26 / \mathrm{Mar} / 2006$ & 7.7 & -1.1 & 3.3 & 14.7 & 0 & $T$ & 0 & $T$ & 0 & 35 & 39 \\
\hline $27 / \mathrm{Mar} / 2006$ & 12.2 & -2.2 & 5 & 13 & 0 & 0 & 0 & 0 & 0 & & $<31$ \\
\hline $28 / \mathrm{Mar} / 2006$ & 11.1 & -2.4 & 4.4 & 13.6 & 0 & 0 & 0 & 0 & 0 & & $<31$ \\
\hline 29/Mar/2006 & 13.5 & -0.5 & 6.5 & 11.5 & 0 & 0 & 0 & 0 & 0 & & $<31$ \\
\hline $30 / \mathrm{Mar} / 2006$ & 15.6 & 0.2 & 7.9 & 10.1 & 0 & 0 & 0 & 0 & 0 & & $<31$ \\
\hline 31/Mar/2006 & 17.8 & 2.4 & 10.1 & 7.9 & 0 & 3.2 & 0 & 3.2 & 0 & 24 & 46 \\
\hline $01 / \mathrm{Apr} / 2006$ & 13.8 & 2.3 & 8.1 & 9.9 & 0 & 0.8 & 0 & 0.8 & 0 & 29 & 63 \\
\hline $02 / \mathrm{Apr} / 2006$ & 9.8 & -0.8 & 4.5 & 13.5 & 0 & 0 & 0 & 0 & 0 & $M$ & $M$ \\
\hline 03/Apr/2006 & 15.1 & 2.5 & 8.8 & 9.2 & 0 & 5.2 & 0 & 5.2 & 0 & 29 & 65 \\
\hline
\end{tabular}




\begin{tabular}{|c|c|c|c|c|c|c|c|c|c|c|c|}
\hline $04 / \mathrm{Apr} / 2006$ & 7 & -2.8 & 2.1 & 15.9 & 0 & 0.2 & $\mathrm{~T}$ & 0.2 & 0 & 33 & 61 \\
\hline $05 / \mathrm{Apr} / 2006$ & 4.6 & -3.4 & 0.6 & 17.4 & 0 & 0.8 & $\mathrm{~T}$ & 0.8 & $\mathrm{~T}$ & 34 & 44 \\
\hline $06 / \mathrm{Apr} / 2006$ & 14.2 & 0.3 & 7.3 & 10.7 & 0 & 0 & 0 & 0 & 0 & 31 & 32 \\
\hline $07 / \mathrm{Apr} / 2006$ & 7.8 & -0.4 & 3.7 & 14.3 & 0 & 12.2 & $\mathrm{~T}$ & 12.2 & 0 & 36 & 46 \\
\hline $08 / \mathrm{Apr} / 2006$ & 5 & -4.3 & 0.4 & 17.6 & 0 & 0 & 0 & 0 & 0 & 2 & 39 \\
\hline $09 / \mathrm{Apr} / 2006$ & 11.2 & -3.3 & 4 & 14 & 0 & 0 & 0 & 0 & 0 & & $<31$ \\
\hline $10 / \mathrm{Apr} / 2006$ & 16.5 & 0.5 & 8.5 & 9.5 & 0 & 0 & 0 & 0 & 0 & 19 & 33 \\
\hline $11 / \mathrm{Apr} / 2006$ & 16 & 4.6 & 10.3 & 7.7 & 0 & 0 & 0 & 0 & 0 & & $<31$ \\
\hline $12 / \mathrm{Apr} / 2006$ & 17.4 & 6.3 & 11.9 & 6.1 & 0 & 7 & 0 & 7 & 0 & 29 & 70 \\
\hline $13 / \mathrm{Apr} / 2006$ & 21.2 & 8 & 14.6 & 3.4 & 0 & 0.4 & 0 & 0.4 & 0 & 31 & 54 \\
\hline $14 / \mathrm{Apr} / 2006$ & 13.3 & 7.2 & 10.3 & 7.7 & 0 & 3.2 & 0 & 3.2 & 0 & & $<31$ \\
\hline $15 / \mathrm{Apr} / 2006$ & 16 & 5.5 & 10.8 & 7.2 & 0 & 0 & 0 & 0 & 0 & 34 & 50 \\
\hline $16 / \mathrm{Apr} / 2006$ & 14.5 & 3.7 & 9.1 & 8.9 & 0 & 0 & 0 & 0 & 0 & 36 & 33 \\
\hline $17 / \mathrm{Apr} / 2006$ & 13.2 & 1.6 & 7.4 & 10.6 & 0 & 0 & 0 & 0 & 0 & & $<31$ \\
\hline $18 / \mathrm{Apr} / 2006$ & 17.1 & 4.4 & 10.8 & 7.2 & 0 & 0 & 0 & 0 & 0 & & $<31$ \\
\hline $19 / \mathrm{Apr} / 2006$ & 19.8 & 6.7 & 13.3 & 4.7 & 0 & 0 & 0 & 0 & 0 & & $<31$ \\
\hline $20 / \mathrm{Apr} / 2006$ & 22.7 & 8.3 & 15.5 & 2.5 & 0 & 0 & 0 & 0 & 0 & & $<31$ \\
\hline $21 / \mathrm{Apr} / 2006$ & 19.3 & 10.9 & 15.1 & 2.9 & 0 & 0.2 & 0 & 0.2 & 0 & 11 & 44 \\
\hline $22 / \mathrm{Apr} / 2006$ & 11.4 & 6.6 & 9 & 9 & 0 & 7.2 & 0 & 7.2 & 0 & 9 & 33 \\
\hline $23 / \mathrm{Apr} / 2006$ & 7.2 & 4.7 & 6 & 12 & 0 & 22 & 0 & 22 & 0 & 8 & 35 \\
\hline $24 / \mathrm{Apr} / 2006$ & 13.9 & 4.7 & 9.3 & 8.7 & 0 & 2.6 & 0 & 2.6 & 0 & 29 & 46 \\
\hline $25 / \mathrm{Apr} / 2006$ & 11.4 & 0.3 & 5.9 & 12.1 & 0 & 0.6 & $T$ & 0.6 & $\mathrm{~T}$ & 34 & 61 \\
\hline $26 / \mathrm{Apr} / 2006$ & 17.2 & -1.6 & 7.8 & 10.2 & 0 & 0 & 0 & 0 & 0 & 27 & 63 \\
\hline $27 / \mathrm{Apr} / 2006$ & 12.5 & 1.9 & 7.2 & 10.8 & 0 & 0 & 0 & 0 & 0 & 1 & 35 \\
\hline $28 / \mathrm{Apr} / 2006$ & 10.7 & -0.1 & 5.3 & 12.7 & 0 & 0 & 0 & 0 & 0 & & $<31$ \\
\hline $29 / \mathrm{Apr} / 2006$ & 15.1 & -0.2 & 7.5 & 10.5 & 0 & 0 & 0 & 0 & 0 & 11 & 37 \\
\hline $30 / \mathrm{Apr} / 2006$ & 18.9 & 4.2 & 11.6 & 6.4 & 0 & 0 & 0 & 0 & 0 & 9 & 37 \\
\hline & & & & & & & & & & & \\
\hline
\end{tabular}


Daily Data Report for Winter 2006-2007

\begin{tabular}{|c|c|c|c|c|c|c|c|c|c|c|c|}
\hline \multicolumn{3}{|c|}{ Environment Canada } & \multicolumn{5}{|c|}{$\begin{array}{l}\text { Natıonal Clımate Data and Information } \\
\text { Archive }\end{array}$} & \multicolumn{4}{|c|}{ www clımate weatheroffice gc ca } \\
\hline Day & $\begin{array}{l}\text { Max } \\
\text { Temp }\end{array}$ & $\begin{array}{l}\text { Min } \\
\text { Temp }\end{array}$ & $\begin{array}{l}\text { Mean } \\
\text { Temp }\end{array}$ & $\begin{array}{c}\text { Heat } \\
\text { Deg } \\
\text { Days }\end{array}$ & $\begin{array}{l}\text { Cool } \\
\text { Deg } \\
\text { Days }\end{array}$ & $\begin{array}{l}\text { Total } \\
\text { Rain }\end{array}$ & $\begin{array}{l}\text { Total } \\
\text { Snow }\end{array}$ & $\begin{array}{l}\text { Total } \\
\text { Precip }\end{array}$ & $\begin{array}{l}\text { Snow } \\
\text { on } \\
\text { Grnd }\end{array}$ & $\begin{array}{l}\text { Dir of } \\
\text { Max } \\
\text { Gust }\end{array}$ & $\begin{array}{l}\text { Spd of } \\
\text { Max } \\
\text { Gust }\end{array}$ \\
\hline & ${ }^{\circ} \mathrm{C}$ & ${ }^{\circ} \mathrm{C}$ & ${ }^{\circ} \mathrm{C}$ & ${ }^{\circ} \mathrm{C}$ & ${ }^{\circ} \mathrm{C}$ & $\mathrm{mm}$ & $\mathrm{cm}$ & $\mathrm{mm}$ & $\mathrm{cm}$ & 10's Deg & $\mathrm{km} / \mathrm{h}$ \\
\hline $31 / \mathrm{Oct} / 2006$ & 165 & 35 & 99 & 8 & 0 & 02 & 0 & 02 & 0 & 24 & 46 \\
\hline $01 /$ Nov/2006 & 89 & -07 & 41 & 139 & 0 & 0 & 0 & 0 & 0 & 26 & 37 \\
\hline $02 / \mathrm{Nov} / 2006$ & 46 & -19 & 14 & 166 & 0 & 0 & $T$ & $T$ & 0 & 27 & 46 \\
\hline $03 / \mathrm{Nov} / 2006$ & 5 & -26 & 12 & 168 & 0 & 0 & 0 & 0 & 0 & 27 & 50 \\
\hline $04 /$ Nov/2006 & 57 & -38 & 1 & 17 & 0 & 0 & 0 & 0 & 0 & & $<31$ \\
\hline $05 / \mathrm{Nov} / 2006$ & 107 & 37 & 72 & 108 & 0 & $T$ & 0 & $T$ & 0 & & $<31$ \\
\hline $06 /$ Nov/2006 & 144 & -05 & 7 & 11 & 0 & 0 & 0 & 0 & 0 & & $<31$ \\
\hline $07 /$ Nov/2006 & 109 & 72 & 91 & 89 & 0 & 12 & 0 & 12 & 0 & & $<31$ \\
\hline $08 /$ Nov/2006 & 113 & 77 & 95 & 85 & 0 & 03 & 0 & 03 & 0 & & $<31$ \\
\hline $09 /$ Nov/2006 & 152 & 46 & 99 & 81 & 0 & $T$ & 0 & $T$ & 0 & 30 & 50 \\
\hline $10 / \mathrm{Nov} / 2006$ & 78 & 34 & 56 & 124 & 0 & 0 & 0 & 0 & 0 & 31 & 35 \\
\hline $11 /$ Nov/2006 & 72 & 17 & 45 & 135 & 0 & 6 & 0 & 6 & 0 & 36 & 39 \\
\hline $12 /$ Nov/2006 & 44 & 07 & 26 & 154 & 0 & 0 & 0 & 0 & 0 & 36 & 32 \\
\hline $13 /$ Nov/2006 & 56 & 32 & 44 & 136 & 0 & 02 & 0 & 02 & 0 & & $<31$ \\
\hline $14 /$ Nov/2006 & 68 & 31 & 5 & 13 & 0 & 0 & 0 & 0 & 0 & & $<31$ \\
\hline $15 /$ Nov/2006 & 10 & 34 & 67 & 113 & 0 & 58 & 0 & 58 & 0 & & $<31$ \\
\hline $16 /$ Nov/2006 & 137 & 66 & 102 & 78 & 0 & 254 & 0 & 254 & 0 & 7 & 33 \\
\hline $17 / \mathrm{Nov} / 2006$ & 67 & 23 & 45 & 135 & 0 & 42 & 0 & 42 & 0 & 29 & 48 \\
\hline $18 /$ Nov/2006 & 6 & 13 & 37 & 143 & 0 & 0 & 0 & 0 & 0 & & $<31$ \\
\hline $19 /$ Nov/2006 & 21 & -1 & 06 & 174 & 0 & 0 & $T$ & $T$ & 0 & & $<31$ \\
\hline $20 /$ Nov/2006 & 18 & -08 & 05 & 175 & 0 & 0 & $T$ & $T$ & $T$ & 35 & 32 \\
\hline $21 / \mathrm{Nov} / 2006$ & 65 & -26 & 2 & 16 & 0 & 0 & 0 & 0 & 0 & & $<31$ \\
\hline $22 /$ Nov/2006 & 81 & -31 & 25 & 155 & 0 & 0 & 0 & 0 & 0 & & $<31$ \\
\hline $23 /$ Nov/2006 & 72 & -3 & 21 & 159 & 0 & 0 & 0 & 0 & 0 & & $<31$ \\
\hline $24 /$ Nov/2006 & 83 & -07 & 38 & 142 & 0 & 0 & 0 & 0 & 0 & & $<31$ \\
\hline $25 /$ Nov/2006 & 67 & -2 & 24 & 156 & 0 & 0 & 0 & 0 & 0 & & $<31$ \\
\hline $26 /$ Nov/2006 & 14 & 27 & 84 & 96 & 0 & 0 & 0 & 0 & 0 & & $<31$ \\
\hline $27 /$ Nov $/ 2006$ & 143 & 56 & 10 & 8 & 0 & 0 & 0 & 0 & 0 & & $<31$ \\
\hline $28 /$ Nov/2006 & 98 & 55 & 77 & 103 & 0 & 0 & 0 & 0 & 0 & 9 & 32 \\
\hline $29 /$ Nov/2006 & 161 & 56 & 109 & 71 & 0 & 02 & 0 & 02 & 0 & 20 & 37 \\
\hline $30 /$ Nov/2006 & 159 & 27 & 93 & 87 & 0 & 176 & 0 & 176 & 0 & 35 & 50 \\
\hline $01 / \mathrm{Dec} / 2006$ & 46 & 05 & 26 & 154 & 0 & 282 & $T$ & 282 & 0 & 26 & 83 \\
\hline $02 / \mathrm{Dec} / 2006$ & 24 & -15 & 05 & 175 & 0 & 0 & $T$ & $T$ & 0 & 27 & 74 \\
\hline $03 / \mathrm{Dec} / 2006$ & 03 & -53 & -25 & 205 & 0 & 0 & $T$ & $T$ & 0 & 27 & 39 \\
\hline $04 / \mathrm{Dec} / 2006$ & -02 & -64 & -33 & 213 & 0 & 0 & 04 & 04 & $T$ & 30 & 39 \\
\hline $05 / \mathrm{Dec} / 2006$ & 0 & -71 & -36 & 216 & 0 & 0 & 0 & 0 & $T$ & 28 & 37 \\
\hline 06/Dec/2006 & 34 & -2 & 07 & 173 & 0 & 06 & 02 & 08 & $T$ & 24 & 48 \\
\hline $07 / \mathrm{Dec} / 2006$ & 06 & -115 & 55 & 235 & 0 & 0 & $T$ & $T$ & 0 & 34 & 50 \\
\hline $08 / \mathrm{Dec} / 2006$ & -12 & -124 & -68 & 248 & 0 & 0 & $T$ & $T$ & $T$ & 26 & 46 \\
\hline $09 / \mathrm{Dec} / 2006$ & 39 & -42 & -02 & 182 & 0 & 0 & 0 & 0 & 0 & 24 & 52 \\
\hline 10/Dec/2006 & 86 & -01 & 43 & 137 & 0 & 02 & 0 & 02 & 0 & 25 & 44 \\
\hline $11 / \mathrm{Dec} / 2006$ & 51 & 23 & 37 & 143 & 0 & 2 & 0 & 2 & 0 & & $<31$ \\
\hline $12 / \mathrm{Dec} / 2006$ & 10 & 44 & 72 & 108 & 0 & 02 & 0 & 02 & 0 & 17 & 33 \\
\hline $13 / \mathrm{Dec} / 2006$ & 97 & 13 & 55 & 125 & 0 & 2 & 0 & 2 & 0 & 22 & 46 \\
\hline 14/Dec/2006 & 124 & 16 & 7 & 11 & 0 & $T$ & 0 & $T$ & 0 & 23 & 65 \\
\hline
\end{tabular}




\begin{tabular}{|c|c|c|c|c|c|c|c|c|c|c|c|}
\hline 15/Dec/2006 & 10.4 & 2.1 & 6.3 & 11.7 & 0 & $T$ & 0 & $T$ & 0 & 25 & 52 \\
\hline 16/Dec/2006 & 6.6 & 2.5 & 4.6 & 13.4 & 0 & $T$ & 0 & $T$ & 0 & & $<31$ \\
\hline $17 / \mathrm{Dec} / 2006$ & 12.7 & 4.4 & 8.6 & 9.4 & 0 & 0 & 0 & 0 & 0 & & $<31$ \\
\hline $18 / \mathrm{Dec} / 2006$ & 5.8 & 1.7 & 3.8 & 14.2 & 0 & 0 & 0 & 0 & 0 & 32 & 48 \\
\hline 19/Dec/2006 & 4.7 & -2 & 1.4 & 16.6 & 0 & 0 & 0 & 0 & 0 & 29 & 37 \\
\hline 20/Dec/2006 & 7.7 & -2.2 & 2.8 & 15.2 & 0 & 0 & 0 & 0 & 0 & 26 & 57 \\
\hline 21/Dec/2006 & 7 & 1.7 & 4.4 & 13.6 & 0 & $T$ & 0 & $T$ & 0 & & $<31$ \\
\hline $22 / \mathrm{Dec} / 2006$ & 7.6 & 3 & 5.3 & 12.7 & 0 & 15.2 & 0 & 15.2 & 0 & 9 & 44 \\
\hline 23/Dec/2006 & 7.4 & 2.7 & 5.1 & 12.9 & 0 & 1.4 & 0 & 1.4 & 0 & 25 & 57 \\
\hline 24/Dec/2006 & 6.4 & -0.9 & 2.8 & 15.2 & 0 & $\mathrm{~T}$ & 0 & $\mathrm{~T}$ & 0 & 25 & 48 \\
\hline 25/Dec/2006 & 4.9 & -0.8 & 2.1 & 15.9 & 0 & 1.4 & 0 & 1.4 & 0 & & $<31$ \\
\hline $26 / \mathrm{Dec} / 2006$ & 3.8 & -1.7 & 1.1 & 16.9 & 0 & 1 & 0 & 1 & 0 & 35 & 41 \\
\hline $27 / \mathrm{Dec} / 2006$ & 1.8 & -1.7 & 0.1 & 17.9 & 0 & 0 & $T$ & $\mathrm{~T}$ & $\mathrm{~T}$ & 26 & 35 \\
\hline $28 / \mathrm{Dec} / 2006$ & 4.9 & -1.1 & 1.9 & 16.1 & 0 & 0.2 & 0.6 & 1 & 0 & & $<31$ \\
\hline 29/Dec/2006 & 0.2 & -3.6 & -1.7 & 19.7 & 0 & 0 & $T$ & $T$ & $T$ & & $<31$ \\
\hline $30 / \mathrm{Dec} / 2006$ & 2.5 & -4.2 & -0.9 & 18.9 & 0 & $T$ & 0.4 & 0.4 & $T$ & & $<31$ \\
\hline $31 / \mathrm{Dec} / 2006$ & 5.2 & -4.8 & 0.2 & 17.8 & 0 & 8.2 & 0 & 8.2 & 0 & 11 & 46 \\
\hline $01 / \mathrm{Jan} / 2007$ & 9.2 & 1.2 & 5.2 & 12.8 & 0 & $\mathrm{~T}$ & 0 & $T$ & 0 & 25 & 56 \\
\hline $02 / \operatorname{Jan} / 2007$ & 5.8 & -2.5 & 1.7 & 16.3 & 0 & 0 & 0 & 0 & 0 & 30 & 50 \\
\hline $03 / \operatorname{Jan} / 2007$ & 8 & 0 & 4 & 14 & 0 & 0 & 0 & 0 & 0 & 24 & 52 \\
\hline $04 / \operatorname{Jan} / 2007$ & 11.9 & 4.4 & 8.2 & 9.8 & 0 & 2.8 & 0 & 2.8 & 0 & 22 & 48 \\
\hline $05 / \operatorname{Jan} / 2007$ & 11.1 & 7.4 & 9.3 & 8.7 & 0 & 6 & 0 & 6 & 0 & & $<31$ \\
\hline $06 / \operatorname{Jan} / 2007$ & 9 & 1.1 & 5.1 & 12.9 & 0 & 3.4 & 0 & 3.4 & 0 & 30 & 46 \\
\hline $07 / \operatorname{Jan} / 2007$ & 4.7 & 1.4 & 3.1 & 14.9 & 0 & 0.8 & $T$ & 0.8 & 0 & 12 & 46 \\
\hline $08 / \mathrm{Jan} / 2007$ & 4.1 & -2 & 1.1 & 16.9 & 0 & 3.2 & $\mathrm{~T}$ & 3.2 & 0 & 26 & 78 \\
\hline $09 / \operatorname{Jan} / 2007$ & 1.2 & -5.2 & -2 & 20 & 0 & 0 & $T$ & $T$ & $T$ & 29 & 52 \\
\hline $10 / \operatorname{Jan} / 2007$ & -2.6 & -7.8 & -5.2 & 23.2 & 0 & 0 & $T$ & $T$ & $T$ & 31 & 50 \\
\hline $11 / \operatorname{Jan} / 2007$ & 6.7 & -6.9 & -0.1 & 18.1 & 0 & $\mathrm{~T}$ & 0 & $T$ & 0 & 22 & 54 \\
\hline $12 / \operatorname{Jan} / 2007$ & 7.6 & 1.9 & 4.8 & 13.2 & 0 & 2.6 & 0 & 2.6 & 0 & 34 & 35 \\
\hline $13 / \operatorname{Jan} / 2007$ & 3.8 & -3.5 & 0.2 & 17.8 & 0 & $T$ & 0.2 & 0.2 & $T$ & 35 & 46 \\
\hline $14 / \operatorname{Jan} / 2007$ & -0.8 & -2.6 & -1.7 & 19.7 & 0 & 0 & 1.4 & 1.8 & $T$ & & $<31$ \\
\hline $15 / \operatorname{Jan} / 2007$ & -1.1 & -6.6 & -3.9 & 21.9 & 0 & 3 & 5.8 & 8.8 & 2 & 36 & 39 \\
\hline $16 / \operatorname{Jan} / 2007$ & -6.5 & -12.5 & -9.5 & 27.5 & 0 & 0 & $T$ & $T$ & 4 & 30 & 48 \\
\hline $17 / \operatorname{Jan} / 2007$ & -3.2 & -11.1 & -7.2 & 25.2 & 0 & 0 & $T$ & $T$ & 4 & & $<31$ \\
\hline $18 / \operatorname{Jan} / 2007$ & 0.8 & -4.4 & -1.8 & 19.8 & 0 & 0 & 0.2 & 0.2 & 3 & 22 & 32 \\
\hline $19 / \operatorname{Jan} / 2007$ & 0.3 & -6.3 & -3 & 21 & 0 & 0 & 0.2 & 0.2 & 3 & 28 & 56 \\
\hline 20/Jan/2007 & -5.8 & -12.2 & -9 & 27 & 0 & 0 & $T$ & $\mathrm{~T}$ & 3 & 31 & 48 \\
\hline $21 / \operatorname{Jan} / 2007$ & -3.8 & -12.8 & -8.3 & 26.3 & 0 & 0 & $\mathrm{~T}$ & $\mathrm{~T}$ & 2 & 11 & 32 \\
\hline $22 / \operatorname{Jan} / 2007$ & -3.8 & -8.6 & -6.2 & 24.2 & 0 & 0 & 1 & 1 & 3 & & $<31$ \\
\hline $23 / \mathrm{Jan} / 2007$ & -0.2 & -6.8 & -3.5 & 21.5 & 0 & 0 & $T$ & $\mathrm{~T}$ & 3 & 23 & 41 \\
\hline $24 / \operatorname{Jan} / 2007$ & -2.1 & -10.9 & -6.5 & 24.5 & 0 & 0 & 0.2 & 0.2 & 3 & & $<31$ \\
\hline $25 / \mathrm{Jan} / 2007$ & -10.7 & -17.5 & -14.1 & 32.1 & 0 & 0 & $\mathrm{~T}$ & $\mathrm{~T}$ & 3 & 34 & 52 \\
\hline $26 / \mathrm{Jan} / 2007$ & -5.1 & -13.1 & -9.1 & 27.1 & 0 & $T$ & 2.8 & 2.6 & 3 & 13 & 37 \\
\hline $27 / \operatorname{Jan} / 2007$ & -1 & -5.3 & -3.2 & 21.2 & 0 & 1.6 & 0.8 & 2 & 5 & & $<31$ \\
\hline $28 / \mathrm{Jan} / 2007$ & -2.6 & -13.2 & -7.9 & 25.9 & 0 & 0 & 2.6 & 2.2 & 5 & & $<31$ \\
\hline $29 / \mathrm{Jan} / 2007$ & -5.9 & -16.8 & -11.4 & 29.4 & 0 & 0 & $\mathrm{~T}$ & $\mathrm{~T}$ & 7 & 25 & 44 \\
\hline $30 / \operatorname{Jan} / 2007$ & -5.8 & -12.6 & -9.2 & 27.2 & 0 & 0 & 0.6 & 0.6 & 7 & & $<31$ \\
\hline $31 / \operatorname{Jan} / 2007$ & -5 & -13 & -9 & 27 & 0 & 0 & $T$ & $T$ & 7 & 27 & 57 \\
\hline $01 / \mathrm{Feb} / 2007$ & -2.1 & -8.3 & -5.2 & 23.2 & 0 & 0 & 0.2 & 0.2 & 7 & 22 & 46 \\
\hline $02 / \mathrm{Feb} / 2007$ & -2.4 & -11 & -6.7 & 24.7 & 0 & 0 & $\mathrm{~T}$ & $T$ & 7 & 26 & 57 \\
\hline $03 / \mathrm{Feb} / 2007$ & -7.3 & -14.2 & -10.8 & 28.8 & 0 & 0 & 0.4 & 0.2 & 7 & 26 & 63 \\
\hline $04 / \mathrm{Feb} / 2007$ & -13.9 & -16.5 & -15.2 & 33.2 & 0 & 0 & $T$ & $T$ & 7 & 26 & 57 \\
\hline $05 / \mathrm{Feb} / 2007$ & -10.3 & -16.8 & -13.6 & 31.6 & 0 & 0 & 2.6 & 2.6 & 7 & 26 & 67 \\
\hline $06 / \mathrm{Feb} / 2007$ & -10 & -15.7 & -12.9 & 30.9 & 0 & 0 & 0 & 0 & 9 & 25 & 56 \\
\hline $07 / \mathrm{Feb} / 2007$ & -8.3 & -16 & -12.2 & 30.2 & 0 & 0 & $\mathrm{~T}$ & $T$ & 9 & 24 & 59 \\
\hline
\end{tabular}




\begin{tabular}{|c|c|c|c|c|c|c|c|c|c|c|c|}
\hline $08 / \mathrm{Feb} / 2007$ & -4.8 & -10.9 & -7.9 & 25.9 & 0 & 0 & 0.2 & 0.2 & 9 & 25 & 56 \\
\hline $09 / \mathrm{Feb} / 2007$ & -3.6 & -15 & -9.3 & 27.3 & 0 & 0 & $T$ & $T$ & 9 & 29 & 44 \\
\hline $10 / \mathrm{Feb} / 2007$ & -4.6 & -10.9 & -7.8 & 25.8 & 0 & 0 & $T$ & $\mathrm{~T}$ & 9 & 28 & 54 \\
\hline $11 / \mathrm{Feb} / 2007$ & -5.6 & -11.8 & -8.7 & 26.7 & 0 & 0 & $T$ & $T$ & 9 & 24 & 56 \\
\hline $12 / \mathrm{Feb} / 2007$ & -5.9 & -15.6 & -10.8 & 28.8 & 0 & 0 & $T$ & $T$ & 9 & 35 & 37 \\
\hline $13 / \mathrm{Feb} / 2007$ & -13.7 & -17.5 & -15.6 & 33.6 & 0 & 0 & 3.6 & 3.6 & 9 & 5 & 39 \\
\hline 14/Feb/2007 & -10.6 & -16.5 & -13.6 & 31.6 & 0 & 0 & 6.6 & 4.6 & 16 & 31 & 52 \\
\hline $15 / \mathrm{Feb} / 2007$ & -9.4 & -21 & -15.2 & 33.2 & 0 & 0 & $T$ & $T$ & 19 & 30 & 52 \\
\hline $16 / \mathrm{Feb} / 2007$ & -5.2 & -11.6 & -8.4 & 26.4 & 0 & 0 & 0.2 & 0.2 & 18 & 27 & 50 \\
\hline $17 / \mathrm{Feb} / 2007$ & -5.2 & -11.8 & -8.5 & 26.5 & 0 & 0 & $\mathrm{~T}$ & $T$ & 18 & 25 & 32 \\
\hline $18 / \mathrm{Feb} / 2007$ & -8.5 & -18.1 & -13.3 & 31.3 & 0 & 0 & $T$ & $T$ & 17 & 32 & 54 \\
\hline 19/Feb/2007 & 0.1 & -16 & -8 & 26 & 0 & 0 & $T$ & $T$ & 17 & 13 & 39 \\
\hline $20 / \mathrm{Feb} / 2007$ & 4.3 & -4.6 & -0.2 & 18.2 & 0 & 0 & 0 & 0 & 16 & & $<31$ \\
\hline $21 / \mathrm{Feb} / 2007$ & 3.8 & -6.5 & -1.4 & 19.4 & 0 & 0 & 0 & 0 & 9 & & $<31$ \\
\hline $22 / \mathrm{Feb} / 2007$ & 3.9 & -7.1 & -1.6 & 19.6 & 0 & $\mathrm{~T}$ & 3.6 & 3.6 & 5 & 32 & 76 \\
\hline 23/Feb/2007 & -5.7 & -11.8 & -8.8 & 26.8 & 0 & 0 & $\mathrm{~T}$ & $T$ & 3 & 34 & 56 \\
\hline $24 / \mathrm{Feb} / 2007$ & -2.8 & -12.3 & -7.6 & 25.6 & 0 & 0 & 0 & 0 & 3 & 35 & 46 \\
\hline $25 / \mathrm{Feb} / 2007$ & -1.2 & -8.8 & -5 & 23 & 0 & 0 & 3.8 & 3.6 & 2 & 8 & 57 \\
\hline $26 /$ Feb/2007 & -1.7 & -4.2 & -3 & 21 & 0 & 0 & 6 & 5.8 & 6 & 8 & 33 \\
\hline $27 / \mathrm{Feb} / 2007$ & 0.3 & -4.2 & -2 & 20 & 0 & 0 & $T$ & $T$ & 11 & & $<31$ \\
\hline $28 / \mathrm{Feb} / 2007$ & 1.5 & -7.1 & -2.8 & 20.8 & 0 & 0 & 0 & 0 & 11 & & $<31$ \\
\hline $01 / \mathrm{Mar} / 2007$ & -0.4 & -7.7 & -4.1 & 22.1 & 0 & 2.8 & 5.7 & 9.2 & 9 & 9 & 63 \\
\hline $02 / \mathrm{Mar} / 2007$ & 3.2 & -1.4 & 0.9 & 17.1 & 0 & 4.6 & 1 & 6 & 10 & $M$ & $M$ \\
\hline 03/Mar/2007 & 0.1 & -3.4 & -1.7 & 19.7 & 0 & 0 & $T$ & $T$ & 6 & 23 & 52 \\
\hline 04/Mar/2007 & -1.2 & -4.1 & -2.7 & 20.7 & 0 & 0 & $T$ & $T$ & 6 & 28 & 57 \\
\hline $05 / \mathrm{Mar} / 2007$ & -2.7 & -18.3 & -10.5 & 28.5 & 0 & 0 & 1 & 1 & 6 & 30 & 70 \\
\hline $06 / \mathrm{Mar} / 2007$ & -12.3 & -22.1 & -17.2 & 35.2 & 0 & 0 & 0.8 & 0.8 & 7 & 34 & 44 \\
\hline $07 / \mathrm{Mar} / 2007$ & -6.1 & -15.4 & -10.8 & 28.8 & 0 & 0 & 0.4 & 0.4 & 8 & 27 & 37 \\
\hline $08 / \mathrm{Mar} / 2007$ & -3.4 & -10.7 & -7.1 & 25.1 & 0 & 0 & $T$ & $T$ & 8 & 26 & 37 \\
\hline 09/Mar/2007 & 0.2 & -6.7 & -3.3 & 21.3 & 0 & 0 & 0 & 0 & 8 & 14 & 37 \\
\hline 10/Mar/2007 & 5.8 & -2.8 & 1.5 & 16.5 & 0 & 1.2 & 0 & 1.2 & 5 & 28 & 39 \\
\hline 11/Mar/2007 & 5.7 & -2 & 1.9 & 16.1 & 0 & 0 & 0 & 0 & 2 & 34 & 33 \\
\hline 12/Mar/2007 & 7 & -1.6 & 2.7 & 15.3 & 0 & $T$ & 0 & $T$ & $T$ & & $<31$ \\
\hline 13/Mar/2007 & 15.8 & 3.4 & 9.6 & 8.4 & 0 & 0 & 0 & 0 & $\mathrm{~T}$ & 24 & 50 \\
\hline 14/Mar/2007 & 14.4 & 4.4 & 9.4 & 8.6 & 0 & 0.2 & 0 & 0.2 & $\mathbf{T}$ & 32 & 46 \\
\hline 15/Mar/2007 & 4.7 & -4.3 & 0.2 & 17.8 & 0 & 0 & 0 & 0 & 0 & 34 & 50 \\
\hline 16/Mar/2007 & -2.1 & -6.7 & -4.4 & 22.4 & 0 & 0 & 1.6 & 2 & 0 & 8 & 41 \\
\hline 17/Mar/2007 & 0.5 & -7.3 & -3.4 & 21.4 & 0 & 0 & 2 & 1.8 & 4 & 31 & 52 \\
\hline 18/Mar/2007 & 2.4 & -6.2 & -1.9 & 19.9 & 0 & 0 & 0 & 0 & 1 & 30 & 57 \\
\hline 19/Mar/2007 & 2.6 & -4.2 & -0.8 & 18.8 & 0 & $T$ & 0.8 & 0.8 & $\mathbf{T}$ & 18 & 50 \\
\hline 20/Mar/2007 & -1.5 & -10 & -5.8 & 23.8 & 0 & 0 & $T$ & $T$ & $\mathrm{~T}$ & 30 & 61 \\
\hline 21/Mar/2007 & 4.1 & -7.8 & -1.9 & 19.9 & 0 & 0.2 & 0 & 0.2 & $\mathrm{~T}$ & & $<31$ \\
\hline 22/Mar/2007 & 14.9 & -0.6 & 7.2 & 10.8 & 0 & 2.2 & 0 & 2.2 & $\mathbf{T}$ & 24 & 59 \\
\hline 23/Mar/2007 & 11.7 & -1.6 & 5.1 & 12.9 & 0 & 0 & 0 & 0 & 0 & & $<31$ \\
\hline 24/Mar/2007 & 7.6 & -0.5 & 3.6 & 14.4 & 0 & 2.2 & 0 & 2.2 & 0 & & $<31$ \\
\hline 25/Mar/2007 & 3 & 0 & 1.5 & 16.5 & 0 & 0 & 0 & 0 & 0 & & $<31$ \\
\hline 26/Mar/2007 & 20.3 & 2.6 & 11.5 & 6.5 & 0 & 5.4 & 0 & 5.4 & 0 & 33 & 52 \\
\hline $27 / \mathrm{Mar} / 2007$ & 18.9 & 6.5 & 12.7 & 5.3 & 0 & 0 & 0 & 0 & 0 & 1 & 46 \\
\hline 28/Mar/2007 & 9.6 & 1.6 & 5.6 & 12.4 & 0 & 0 & 0 & 0 & 0 & 7 & 33 \\
\hline 29/Mar/2007 & 8.3 & -2.8 & 2.8 & 15.2 & 0 & 0 & 0 & 0 & 0 & & $<31$ \\
\hline $30 / \mathrm{Mar} / 2007$ & 12.2 & -1 & 5.6 & 12.4 & 0 & 0 & 0 & 0 & 0 & 36 & 32 \\
\hline $31 / \mathrm{Mar} / 2007$ & 7.9 & 2.2 & 5.1 & 12.9 & 0 & 0 & 0 & 0 & 0 & 8 & 32 \\
\hline $01 / \mathrm{Apr} / 2007$ & 7.8 & 4.1 & 6 & 12 & 0 & 5.6 & 0 & 5.6 & 0 & & $<31$ \\
\hline $02 / \mathrm{Apr} / 2007$ & 12.4 & 2.9 & 7.7 & 10.3 & 0 & 0.2 & 0 & 0.2 & 0 & 25 & 57 \\
\hline $03 / \mathrm{Apr} / 2007$ & 9.6 & 0.7 & 5.2 & 12.8 & 0 & 10.6 & 0 & 10.6 & 0 & 9 & 37 \\
\hline
\end{tabular}




\begin{tabular}{|c|c|c|c|c|c|c|c|c|c|c|c|}
\hline $04 / \mathrm{Apr} / 2007$ & 9.9 & -3.9 & 3 & 15 & 0 & 8 & $\mathrm{~T}$ & 8 & 0 & 26 & 59 \\
\hline $05 / \mathrm{Apr} / 2007$ & -2.1 & -6.6 & -4.4 & 22.4 & 0 & 0 & 0.6 & 0.6 & $\mathrm{~T}$ & 28 & 59 \\
\hline $06 / \mathrm{Apr} / 2007$ & -2.2 & -7.2 & -4.7 & 22.7 & 0 & 0 & 0.2 & 0.2 & $\mathrm{~T}$ & 29 & 48 \\
\hline $07 / \mathrm{Apr} / 2007$ & -0.7 & -6.9 & -3.8 & 21.8 & 0 & 0 & $\mathrm{~T}$ & $\mathrm{~T}$ & $\mathrm{~T}$ & 29 & 44 \\
\hline $08 / \mathrm{Apr} / 2007$ & 1.3 & -5.1 & -1.9 & 19.9 & 0 & 0 & 0.2 & 0.2 & $\mathrm{~T}$ & 28 & 39 \\
\hline $09 / \mathrm{Apr} / 2007$ & 3 & -3.9 & -0.5 & 18.5 & 0 & 0 & $\mathrm{~T}$ & $\mathrm{~T}$ & 0 & 28 & 33 \\
\hline 10/Apr/2007 & 5.8 & -4.2 & 0.8 & 17.2 & 0 & 0 & 0 & 0 & 0 & 29 & 32 \\
\hline 11/Apr/2007 & 5.1 & -4.7 & 0.2 & 17.8 & 0 & 5.4 & $\mathrm{~T}$ & 5.4 & 0 & 8 & 63 \\
\hline 12/Apr/2007 & 9.3 & 1.7 & 5.5 & 12.5 & 0 & 4.6 & $\mathrm{~T}$ & 4.6 & 0 & 9 & 54 \\
\hline 13/Apr/2007 & 5.2 & -1.1 & 2.1 & 15.9 & 0 & 0.4 & 0.6 & 1 & 0 & 28 & 61 \\
\hline 14/Apr/2007 & 6.7 & -1.9 & 2.4 & 15.6 & 0 & 0.2 & $\mathrm{~T}$ & 0.2 & 0 & & $<31$ \\
\hline 15/Apr/2007 & 7.2 & 1 & 4.1 & 13.9 & 0 & 0.8 & 0.8 & 1.6 & 0 & 34 & 52 \\
\hline 16/Apr/2007 & 5.3 & 2.8 & 4.1 & 13.9 & 0 & 1.8 & 0 & 1.8 & 0 & 34 & 74 \\
\hline 17/Apr/2007 & 8.7 & 3.5 & 6.1 & 11.9 & 0 & $\mathrm{~T}$ & 0 & $\mathrm{~T}$ & 0 & 35 & 35 \\
\hline 18/Apr/2007 & 10 & 3.9 & 7 & 11 & 0 & 0 & 0 & 0 & 0 & 6 & 32 \\
\hline 19/Apr/2007 & 14.7 & 3.4 & 9.1 & 8.9 & 0 & 0 & 0 & 0 & 0 & $\mathrm{M}$ & $\mathrm{M}$ \\
\hline 20/Apr/2007 & 22.3 & 5.3 & 13.8 & 4.2 & 0 & 0 & 0 & 0 & 0 & & $<31$ \\
\hline 21/Apr/2007 & 22.6 & 5.3 & 14 & 4 & 0 & 0 & 0 & 0 & 0 & & $<31$ \\
\hline 22/Apr/2007 & 25.4 & 9.3 & 17.4 & 0.6 & 0 & 0 & 0 & 0 & 0 & 23 & 39 \\
\hline 23/Apr/2007 & 23.7 & 8.5 & 16.1 & 1.9 & 0 & 8.4 & 0 & 8.4 & 0 & 27 & 95 \\
\hline 24/Apr/2007 & 15.8 & 5.5 & 10.7 & 7.3 & 0 & 0 & 0 & 0 & 0 & & $<31$ \\
\hline 25/Apr/2007 & 11.9 & 6.7 & 9.3 & 8.7 & 0 & 0 & 0 & 0 & 0 & & $<31$ \\
\hline 26/Apr/2007 & 10 & 6.4 & 8.2 & 9.8 & 0 & 10.4 & 0 & 10.4 & 0 & 8 & 50 \\
\hline 27/Apr/2007 & 17.5 & 8 & 12.8 & 5.2 & 0 & 1.6 & 0 & 1.6 & 0 & 23 & 46 \\
\hline $28 / \mathrm{Apr} / 2007$ & 11.5 & 5.8 & 8.7 & 9.3 & 0 & 0.4 & 0 & 0.4 & 0 & 29 & 46 \\
\hline $29 / \mathrm{Apr} / 2007$ & 21.4 & 4.6 & 13 & 5 & 0 & $\mathrm{~T}$ & 0 & $\mathrm{~T}$ & 0 & 23 & 52 \\
\hline $30 / \mathrm{Apr} / 2007$ & 16.4 & 6.8 & 11.6 & 6.4 & 0 & 0 & 0 & 0 & 0 & 34 & 48 \\
\hline
\end{tabular}




\begin{tabular}{|c|c|c|c|c|c|c|c|c|c|c|c|}
\hline \multicolumn{12}{|c|}{ Daily Data Report for Winter 2007-2008 } \\
\hline \multicolumn{3}{|c|}{ Environment Canada } & \multicolumn{5}{|c|}{$\begin{array}{l}\text { Natıonal Climate Data and Information } \\
\text { Archive }\end{array}$} & \multicolumn{4}{|c|}{ www clımate weatheroffice gc ca } \\
\hline Day & $\begin{array}{l}\text { Max } \\
\text { Temp }\end{array}$ & $\underset{\text { Temp }}{\operatorname{Min}}$ & $\begin{array}{l}\text { Mean } \\
\text { Temp }\end{array}$ & $\begin{array}{c}\text { Heat } \\
\text { Deg } \\
\text { Days }\end{array}$ & \begin{tabular}{|l|} 
Cool \\
Deg \\
Days
\end{tabular} & $\begin{array}{l}\text { Total } \\
\text { Rain }\end{array}$ & $\begin{array}{l}\text { Total } \\
\text { Snow }\end{array}$ & $\begin{array}{l}\text { Total } \\
\text { Precip }\end{array}$ & $\begin{array}{l}\text { Snow } \\
\text { on } \\
\text { Grnd }\end{array}$ & $\begin{array}{l}\text { Dir of } \\
\text { Max } \\
\text { Gust }\end{array}$ & $\begin{array}{l}\text { Spd of } \\
\text { Max } \\
\text { Gust }\end{array}$ \\
\hline & ${ }^{\circ} \mathrm{C}$ & ${ }^{\circ} \mathrm{C}$ & ${ }^{\circ} \mathrm{C}$ & ${ }^{\circ} \mathrm{C}$ & ${ }^{\circ} \mathrm{C}$ & $\mathrm{mm}$ & $\mathrm{cm}$ & $\mathrm{mm}$ & $\mathrm{cm}$ & 10's Deg & $\mathrm{km} / \mathrm{h}$ \\
\hline $31 /$ Oct/2007 & 188 & 71 & 99 & 5 & 0 & 1 & 0 & 1 & 0 & 27 & 63 \\
\hline $01 /$ Nov/2007 & 106 & 04 & 55 & 125 & 0 & 0 & 0 & 0 & 0 & 28 & 46 \\
\hline $02 /$ Nov/2007 & 99 & -2 & 4 & 14 & 0 & 0 & 0 & 0 & 0 & & $<31$ \\
\hline 03/Nov/2007 & 143 & 07 & 68 & 112 & 0 & 0 & 0 & 0 & 0 & & $<31$ \\
\hline $04 /$ Nov/2007 & 114 & 13 & 64 & 116 & 0 & 0 & 0 & 0 & 0 & & $<31$ \\
\hline $05 /$ Nov/2007 & 96 & -02 & 47 & 133 & 0 & 56 & 0 & 56 & 0 & 15 & 44 \\
\hline 06/Nov/2007 & 6 & 17 & 39 & 141 & 0 & $\mathrm{~T}$ & 0 & $T$ & 0 & 29 & 63 \\
\hline $07 /$ Nov/2007 & 32 & -04 & 14 & 166 & 0 & 0 & 0 & 0 & 0 & 29 & 41 \\
\hline $08 /$ Nov/2007 & 49 & 04 & 27 & 153 & 0 & 58 & $\mathrm{~T}$ & 58 & 0 & & $<31$ \\
\hline 09/Nov/2007 & 77 & 23 & 5 & 13 & 0 & 36 & 0 & 36 & 0 & & $<31$ \\
\hline $10 /$ Nov/2007 & 72 & -09 & 32 & 148 & 0 & 04 & $T$ & 04 & $T$ & 6 & 32 \\
\hline $11 /$ Nov/2007 & 83 & -25 & 29 & 151 & 0 & 04 & 0 & 04 & 0 & & $<31$ \\
\hline $12 /$ Nov/2007 & 12 & 59 & 9 & 9 & 0 & 46 & 0 & 46 & 0 & & $<31$ \\
\hline $13 /$ Nov/2007 & 131 & 28 & 8 & 10 & 0 & 0 & 0 & 0 & 0 & & $<31$ \\
\hline $14 /$ Nov/2007 & 157 & 53 & 105 & 75 & 0 & 04 & 0 & 04 & 0 & 27 & 57 \\
\hline $15 /$ Nov/2007 & 85 & 1 & 48 & 132 & 0 & 06 & $\mathrm{~T}$ & 06 & 0 & 32 & 46 \\
\hline $16 /$ Nov/2007 & 27 & -09 & 09 & 171 & 0 & $T$ & $T$ & $T$ & $T$ & 31 & 48 \\
\hline $17 /$ Nov $/ 2007$ & 35 & -37 & -01 & 181 & 0 & 0 & 0 & 0 & 0 & & $<31$ \\
\hline $18 /$ Nov/2007 & 43 & -73 & 15 & 195 & 0 & 0 & 0 & 0 & 0 & & $<31$ \\
\hline 19/Nov/2007 & 53 & -37 & 08 & 172 & 0 & 58 & 0 & 58 & 0 & & $<31$ \\
\hline $20 /$ Nov/2007 & 118 & 47 & 83 & 97 & 0 & 36 & 0 & 36 & 0 & & $<31$ \\
\hline $21 /$ Nov/2007 & 5 & 08 & 29 & 151 & 0 & 292 & 04 & 326 & 0 & 5 & 39 \\
\hline $22 /$ Nov/2007 & 11 & -69 & 29 & 209 & 0 & 26 & 76 & 104 & 2 & 2 & 50 \\
\hline $23 /$ Nov/2007 & -41 & -99 & -7 & 25 & 0 & 0 & 0 & 0 & 5 & & $<31$ \\
\hline 24/Nov/2007 & 21 & 8 & -3 & 21 & 0 & 0 & 0 & 0 & 4 & 24 & 48 \\
\hline $25 /$ Nov/2007 & 51 & 19 & 16 & 164 & 0 & 0 & 0 & 0 & 2 & 24 & 44 \\
\hline $26 /$ Nov/2007 & 41 & 04 & 23 & 157 & 0 & 88 & 22 & 11 & $T$ & & $<31$ \\
\hline $27 /$ Nov $/ 2007$ & 43 & -36 & 04 & 176 & 0 & 1 & 04 & 14 & $T$ & 27 & 80 \\
\hline $28 /$ Nov/2007 & 3 & -77 & -24 & 204 & 0 & 0 & $T$ & $T$ & $T$ & 13 & 32 \\
\hline $29 /$ Nov/2007 & 5 & -48 & 01 & 179 & 0 & 12 & $T$ & 12 & 0 & 28 & 65 \\
\hline $30 /$ Nov/2007 & 26 & -6 & -17 & 197 & 0 & 0 & 04 & 04 & 0 & 28 & 67 \\
\hline 01/Dec/2007 & -54 & -11 & 82 & 262 & 0 & 0 & 32 & 32 & $T$ & 12 & 39 \\
\hline $02 / \mathrm{Dec} / 2007$ & 3 & -65 & -18 & 198 & 0 & 146 & 92 & 238 & 11 & 11 & 50 \\
\hline 03/Dec/2007 & 36 & -48 & -06 & 186 & 0 & 16 & 12 & 28 & 3 & 29 & 74 \\
\hline $04 / \mathrm{Dec} / 2007$ & -21 & -75 & -48 & 228 & 0 & 0 & $T$ & $\mathrm{~T}$ & 3 & 30 & 57 \\
\hline 05/Dec/2007 & -73 & -111 & 92 & 272 & 0 & 0 & 0 & 0 & 3 & & $<31$ \\
\hline 06/Dec/2007 & -29 & -86 & -58 & 238 & 0 & 0 & $T$ & $T$ & 3 & 25 & 41 \\
\hline $07 / \mathrm{Dec} / 2007$ & 03 & -45 & 21 & 201 & 0 & 0 & 02 & 02 & 3 & & $<31$ \\
\hline $08 / \mathrm{Dec} / 2007$ & 03 & -32 & -15 & 195 & 0 & 0 & 0 & 0 & 3 & 31 & 35 \\
\hline 09/Dec/2007 & -28 & -43 & -36 & 216 & 0 & 0 & 02 & 02 & 3 & & $<31$ \\
\hline $10 / \mathrm{Dec} / 2007$ & 13 & -39 & -13 & 193 & 0 & 0 & 04 & 04 & 3 & & $<31$ \\
\hline 11/Dec/2007 & 2 & -46 & -13 & 193 & 0 & 66 & 12 & 78 & 2 & & $<31$ \\
\hline 12/Dec/2007 & 24 & -69 & -23 & 203 & 0 & 0 & 0 & 0 & $T$ & 30 & 57 \\
\hline $13 / \mathrm{Dec} / 2007$ & 21 & -63 & -21 & 201 & 0 & 0 & 3 & 24 & $T$ & 25 & 33 \\
\hline 14/Dec/2007 & 21 & -116 & -48 & 228 & 0 & 0 & $T$ & $T$ & 3 & 31 & 56 \\
\hline
\end{tabular}




\begin{tabular}{|c|c|c|c|c|c|c|c|c|c|c|c|}
\hline $15 / \mathrm{Dec} / 2007$ & -3.5 & -13.2 & -8.4 & 26.4 & 0 & 0 & 3.2 & 2.8 & 2 & 11 & 54 \\
\hline $16 / \mathrm{Dec} / 2007$ & -2.8 & -10.3 & -6.6 & 24.6 & 0 & $\mathrm{~T}$ & 16.8 & 17.1 & 7 & 35 & 57 \\
\hline $17 / \mathrm{Dec} / 2007$ & -3.1 & -10.8 & -7 & 25 & 0 & 0 & $T$ & $T$ & 21 & 31 & 37 \\
\hline $18 / \mathrm{Dec} / 2007$ & 1.3 & -7.3 & -3 & 21 & 0 & 0 & 0 & 0 & 21 & & $<31$ \\
\hline 19/Dec/2007 & 3.3 & 0.2 & 1.8 & 16.2 & 0 & $T$ & 0 & $T$ & 20 & & $<31$ \\
\hline $20 / \mathrm{Dec} / 2007$ & 1.9 & -2.5 & -0.3 & 18.3 & 0 & 0 & 0 & 0 & 12 & & $<31$ \\
\hline 21/Dec/2007 & 2.7 & -2.5 & 0.1 & 17.9 & 0 & 0 & 0 & 0 & 12 & 10 & 37 \\
\hline $22 / \mathrm{Dec} / 2007$ & 4.7 & 2.4 & 3.6 & 14.4 & 0 & 0 & 0 & 0 & 8 & & $<31$ \\
\hline $23 / \mathrm{Dec} / 2007$ & 7.9 & -4.8 & 1.6 & 16.4 & 0 & 20.2 & $T$ & 20.2 & 4 & 24 & 65 \\
\hline $24 /$ Dec/2007 & -1.5 & -5.1 & -3.3 & 21.3 & 0 & 0 & 0.4 & 0.4 & 1 & 25 & 61 \\
\hline $25 / \mathrm{Dec} / 2007$ & -0.6 & -2.8 & -1.7 & 19.7 & 0 & 0 & $T$ & $T$ & 1 & 25 & 33 \\
\hline $26 / \mathrm{Dec} / 2007$ & 1.1 & -5 & -2 & 20 & 0 & 0 & 0 & 0 & 1 & & $<31$ \\
\hline $27 / \mathrm{Dec} / 2007$ & 2.5 & -0.8 & 0.9 & 17.1 & 0 & 0 & 2.8 & 2.6 & 1 & & $<31$ \\
\hline $28 / \mathrm{Dec} / 2007$ & 3.4 & -0.8 & 1.3 & 16.7 & 0 & 6.2 & 0.4 & 6.6 & 1 & 10 & 65 \\
\hline 29/Dec/2007 & 4.1 & -0.8 & 1.7 & 16.3 & 0 & $T$ & $T$ & $T$ & $\mathrm{~T}$ & 23 & 61 \\
\hline $30 / \mathrm{Dec} / 2007$ & 0.4 & -0.9 & -0.3 & 18.3 & 0 & 0 & 0.2 & 0.2 & $\mathrm{~T}$ & & $<31$ \\
\hline $31 / \mathrm{Dec} / 2007$ & 0 & -3.4 & -1.7 & 19.7 & 0 & 0 & 2 & 2 & 2 & & $<31$ \\
\hline $01 / \operatorname{Jan} / 2008$ & 1 & -8.4 & -3.7 & 21.7 & 0 & 0 & 9.4 & 10.2 & 5 & 34 & 48 \\
\hline $02 / \mathrm{Jan} / 2008$ & -8.4 & -15.4 & -11.9 & 29.9 & 0 & 0 & 0 & 0 & 11 & 25 & 44 \\
\hline 03/Jan/2008 & -4.7 & -17.7 & -11.2 & 29.2 & 0 & 0 & 0 & 0 & 11 & 25 & 57 \\
\hline 04/Jan/2008 & -1.7 & -5.5 & -3.6 & 21.6 & 0 & 0 & 0 & 0 & 11 & 23 & 56 \\
\hline $05 / \operatorname{Jan} / 2008$ & 3.4 & -3.6 & -0.1 & 18.1 & 0 & $T$ & $T$ & $\mathrm{~T}$ & 11 & & $<31$ \\
\hline $06 / \mathrm{Jan} / 2008$ & 7.2 & 1.4 & 4.3 & 13.7 & 0 & 0.8 & 0 & 0.8 & 2 & & $<31$ \\
\hline $07 / \mathrm{Jan} / 2008$ & 14.9 & 6.9 & 10.9 & 7.1 & 0 & 2.2 & 0 & 2.2 & $T$ & & $<31$ \\
\hline $08 / \mathrm{Jan} / 2008$ & 15.5 & 11.3 & 13.4 & 4.6 & 0 & 4.2 & 0 & 4.2 & 0 & 21 & 54 \\
\hline $09 / \operatorname{Jan} / 2008$ & 11.6 & 0.8 & 6.2 & 11.8 & 0 & 13.4 & 0 & 13.4 & 0 & 26 & 107 \\
\hline $10 / \mathrm{Jan} / 2008$ & 3.8 & -1.8 & 1 & 17 & 0 & 1.2 & $T$ & 1.2 & 0 & 10 & 52 \\
\hline $11 / \mathrm{Jan} / 2008$ & 8.4 & 1.7 & 5.1 & 12.9 & 0 & 2.8 & 0 & 2.8 & 0 & 23 & 69 \\
\hline $12 / \operatorname{Jan} / 2008$ & 3.9 & -0.7 & 1.6 & 16.4 & 0 & 0 & 0 & 0 & 0 & 25 & 33 \\
\hline $13 / \mathrm{Jan} / 2008$ & 2.7 & -1.9 & 0.4 & 17.6 & 0 & 2.4 & 0.8 & 3.2 & 0 & 10 & 39 \\
\hline 14/Jan/2008 & 3.2 & -0.7 & 1.3 & 16.7 & 0 & 0.4 & 1.6 & 2.2 & $T$ & & $<31$ \\
\hline $15 / \operatorname{Jan} / 2008$ & -0.2 & -3.1 & -1.7 & 19.7 & 0 & 0 & 3 & 2.8 & 1 & & $<31$ \\
\hline $16 / \mathrm{Jan} / 2008$ & -0.1 & -7.7 & -3.9 & 21.9 & 0 & 0 & 0 & 0 & 2 & & $<31$ \\
\hline $17 / \mathrm{Jan} / 2008$ & 2.6 & -0.9 & 0.9 & 17.1 & 0 & 0.4 & 0.4 & 0.8 & 2 & 19 & 35 \\
\hline $18 / \mathrm{Jan} / 2008$ & 2.6 & -5 & -1.2 & 19.2 & 0 & 0.6 & $T$ & 0.6 & $\mathrm{~T}$ & 26 & 83 \\
\hline 19/Jan/2008 & -3.2 & -12.2 & -7.7 & 25.7 & 0 & 0 & $T$ & $T$ & $T$ & 27 & 57 \\
\hline $20 / \operatorname{Jan} / 2008$ & -8.2 & -13.5 & -10.9 & 28.9 & 0 & 0 & $T$ & $T$ & $\mathbf{T}$ & 26 & 69 \\
\hline $21 / \mathrm{Jan} / 2008$ & -6.7 & -12.4 & -9.6 & 27.6 & 0 & 0 & $\mathrm{~T}$ & $T$ & $T$ & 26 & 48 \\
\hline $22 / \mathrm{Jan} / 2008$ & -0.2 & -8.2 & -4.2 & 22.2 & 0 & 0 & 4 & 3.4 & $T$ & 30 & 57 \\
\hline $23 / \mathrm{Jan} / 2008$ & -6.1 & -9.1 & -7.6 & 25.6 & 0 & 0 & $T$ & T & 2 & 27 & 43 \\
\hline $24 / \mathrm{Jan} / 2008$ & -5.7 & -11.3 & -8.5 & 26.5 & 0 & 0 & 0.4 & 0.4 & 2 & 31 & 37 \\
\hline $25 / \mathrm{Jan} / 2008$ & -5.4 & -10.7 & -8.1 & 26.1 & 0 & 0 & 0 & 0 & 2 & 28 & 50 \\
\hline $26 / \mathrm{Jan} / 2008$ & -2.8 & -9.2 & -6 & 24 & 0 & 0 & 2.6 & 2.2 & 2 & & $<31$ \\
\hline $27 / \mathrm{Jan} / 2008$ & -0.6 & -7.1 & -3.9 & 21.9 & 0 & 0 & 0.4 & 0.4 & 4 & & $<31$ \\
\hline $28 / \mathrm{Jan} / 2008$ & 1.7 & -7.6 & -3 & 21 & 0 & 0.2 & 0 & 0.2 & 4 & & $<31$ \\
\hline $29 / \mathrm{Jan} / 2008$ & 8.2 & 1.1 & 4.7 & 13.3 & 0 & 5.8 & 0 & 5.8 & $T$ & 21 & 35 \\
\hline $30 / \mathrm{Jan} / 2008$ & 8.5 & -9.7 & -0.6 & 18.6 & 0 & 1.2 & 0.2 & 1.4 & 0 & 25 & 93 \\
\hline $31 / \mathrm{Jan} / 2008$ & -4.6 & -11.1 & -7.9 & 25.9 & 0 & 0 & 0 & 0 & $T$ & 7 & 32 \\
\hline $01 / \mathrm{Feb} / 2008$ & -0.3 & -4.7 & -2.5 & 20.5 & 0 & 0 & 16.4 & 16.4 & 4 & 10 & 61 \\
\hline $02 / \mathrm{Feb} / 2008$ & 0.1 & -4.1 & -2 & 20 & 0 & 0 & $T$ & $T$ & 16 & 28 & 32 \\
\hline $03 / \mathrm{Feb} / 2008$ & 1.4 & -2.2 & -0.4 & 18.4 & 0 & 0 & $T$ & $T$ & 15 & & $<31$ \\
\hline $04 / \mathrm{Feb} / 2008$ & 2.8 & -1.8 & 0.5 & 17.5 & 0 & 10 & 0.4 & 10.4 & 13 & 10 & 41 \\
\hline $05 / \mathrm{Feb} / 2008$ & 6.6 & -0.2 & 3.2 & 14.8 & 0 & 3.4 & 0.4 & 3.8 & 5 & 2 & 39 \\
\hline $06 / \mathrm{Feb} / 2008$ & 0.2 & -5.9 & -2.9 & 20.9 & 0 & $T$ & 30.4 & 31.4 & 18 & 6 & 54 \\
\hline $07 / \mathrm{Feb} / 2008$ & -2.1 & -8.7 & -5.4 & 23.4 & 0 & 0 & 1.4 & 1.4 & 33 & 1 & 39 \\
\hline
\end{tabular}




\begin{tabular}{|c|c|c|c|c|c|c|c|c|c|c|c|}
\hline $08 / \mathrm{Feb} / 2008$ & -0.5 & -5 & -2.8 & 20.8 & 0 & 0 & 0.4 & 0.4 & 33 & & $<31$ \\
\hline $09 / \mathrm{Feb} / 2008$ & 2.4 & -1.1 & 0.7 & 17.3 & 0 & 0.6 & 6.2 & 7.4 & 33 & 23 & 50 \\
\hline $10 / \mathrm{Feb} / 2008$ & -0.5 & -16.6 & -8.6 & 26.6 & 0 & 0 & 0.4 & 0.4 & 35 & 28 & 80 \\
\hline $11 / \mathrm{Feb} / 2008$ & -9.1 & -18.2 & -13.7 & 31.7 & 0 & 0 & $\mathrm{~T}$ & $T$ & 35 & 24 & 50 \\
\hline $12 / \mathrm{Feb} / 2008$ & -3.3 & -14.5 & -8.9 & 26.9 & 0 & 0 & 12.6 & 10.8 & 35 & 6 & 35 \\
\hline $13 / \mathrm{Feb} / 2008$ & -4 & -9.4 & -6.7 & 24.7 & 0 & 0 & 0.4 & 0.4 & 48 & & $<31$ \\
\hline $14 / \mathrm{Feb} / 2008$ & -0.3 & -6.4 & -3.4 & 21.4 & 0 & 0 & $T$ & $T$ & 48 & 21 & 33 \\
\hline $15 / \mathrm{Feb} / 2008$ & -0.5 & -9.7 & -5.1 & 23.1 & 0 & 0 & $T$ & $T$ & 48 & 26 & 37 \\
\hline $16 / \mathrm{Feb} / 2008$ & -4.5 & -12 & -8.3 & 26.3 & 0 & 0 & 0 & 0 & 48 & & $<31$ \\
\hline $17 / \mathrm{Feb} / 2008$ & 5.5 & -12.6 & -3.6 & 21.6 & 0 & 14.8 & 0 & 14.8 & 45 & 30 & 35 \\
\hline $18 / \mathrm{Feb} / 2008$ & 6.5 & -5.6 & 0.5 & 17.5 & 0 & 1.8 & 0.2 & 2 & 18 & 24 & 80 \\
\hline 19/Feb/2008 & -5.2 & -9.3 & -7.3 & 25.3 & 0 & 0 & 0.2 & 0.2 & 17 & 27 & 56 \\
\hline $20 / \mathrm{Feb} / 2008$ & -6.4 & -13.6 & -10 & 28 & 0 & 0 & $T$ & $\mathrm{~T}$ & 17 & 26 & 37 \\
\hline $21 / \mathrm{Feb} / 2008$ & -5.6 & -13.3 & -9.5 & 27.5 & 0 & 0 & 0 & 0 & 17 & 28 & 32 \\
\hline $22 / \mathrm{Feb} / 2008$ & -1.9 & -8.1 & -5 & 23 & 0 & 0 & 0.4 & 0.4 & 17 & & $<31$ \\
\hline $23 / \mathrm{Feb} / 2008$ & -0.7 & -11.9 & -6.3 & 24.3 & 0 & 0 & 0 & 0 & 17 & & $<31$ \\
\hline $24 / \mathrm{Feb} / 2008$ & 0.9 & -9.9 & -4.5 & 22.5 & 0 & 0 & 0 & 0 & 15 & & $<31$ \\
\hline $25 / \mathrm{Feb} / 2008$ & 1.1 & -7.3 & -3.1 & 21.1 & 0 & 0 & 0 & 0 & 14 & & $<31$ \\
\hline $26 / \mathrm{Feb} / 2008$ & 0.4 & -8.6 & -4.1 & 22.1 & 0 & 0 & 2.2 & 2.2 & 10 & 34 & 52 \\
\hline $27 / \mathrm{Feb} / 2008$ & -8.6 & -15.7 & -12.2 & 30.2 & 0 & 0 & 0 & 0 & 12 & 34 & 54 \\
\hline $28 / \mathrm{Feb} / 2008$ & -9.7 & -18 & -13.9 & 31.9 & 0 & 0 & 0 & 0 & 12 & & $<31$ \\
\hline 29/Feb/2008 & 0.7 & -15.5 & -7.4 & 25.4 & 0 & $T$ & 4.8 & 5.2 & 12 & 11 & 39 \\
\hline $01 / \mathrm{Mar} / 2008$ & 0.4 & -5.1 & -2.4 & 20.4 & 0 & 0 & $T$ & $T$ & 16 & 30 & 59 \\
\hline $02 / \mathrm{Mar} / 2008$ & 0.8 & -7.4 & -3.3 & 21.3 & 0 & $\mathbf{T}$ & 0 & $T$ & 14 & 12 & 33 \\
\hline $03 / \mathrm{Mar} / 2008$ & 12.8 & -0.4 & 6.2 & 11.8 & 0 & 3 & 0 & 3 & 12 & 22 & 50 \\
\hline 04/Mar/2008 & -0.4 & -4.7 & -2.6 & 20.6 & 0 & 0 & 6.8 & 7.4 & 4 & 31 & 44 \\
\hline 05/Mar/2008 & -0.1 & -6.7 & -3.4 & 21.4 & 0 & 0.4 & 8.4 & 8.8 & 16 & 4 & 46 \\
\hline $06 / \mathrm{Mar} / 2008$ & 3.6 & -4.7 & -0.6 & 18.6 & 0 & 0 & $T$ & $\mathrm{~T}$ & 18 & 22 & 33 \\
\hline 07/Mar/2008 & -0.7 & -6.4 & -3.6 & 21.6 & 0 & 0 & 4.2 & 4.2 & 16 & 36 & 39 \\
\hline 08/Mar/2008 & -5.7 & -8.5 & -7.1 & 25.1 & 0 & 0 & 11.2 & 11.2 & 20 & 35 & 65 \\
\hline 09/Mar/2008 & -4.2 & -13.6 & -8.9 & 26.9 & 0 & 0 & 0.2 & 0.2 & 30 & 27 & 46 \\
\hline 10/Mar/2008 & -0.6 & -16.2 & -8.4 & 26.4 & 0 & 0 & 0 & 0 & 28 & & $<31$ \\
\hline 11/Mar/2008 & 0.8 & -11.8 & -5.5 & 23.5 & 0 & 0 & $T$ & $T$ & 26 & 21 & 37 \\
\hline $12 / \mathrm{Mar} / 2008$ & 0.6 & -7.4 & -3.4 & 21.4 & 0 & 0 & 0.4 & 0.2 & 25 & 34 & 46 \\
\hline $13 / \mathrm{Mar} / 2008$ & 3.4 & -8.7 & -2.7 & 20.7 & 0 & 0 & 0.2 & 0.2 & 23 & 10 & 44 \\
\hline $14 / \mathrm{Mar} / 2008$ & 6 & -3 & 1.5 & 16.5 & 0 & $T$ & 0 & $T$ & 22 & & $<31$ \\
\hline $15 / \mathrm{Mar} / 2008$ & 4.8 & -1 & 1.9 & 16.1 & 0 & 0 & 0 & 0 & 16 & & $<31$ \\
\hline 16/Mar/2008 & -0.5 & -5.7 & -3.1 & 21.1 & 0 & 0 & 0 & 0 & 8 & 34 & 50 \\
\hline $17 / \mathrm{Mar} / 2008$ & -0.7 & -8.3 & -4.5 & 22.5 & 0 & 0 & 0 & 0 & 5 & & $<31$ \\
\hline $18 / \mathrm{Mar} / 2008$ & 3.2 & -0.7 & 1.3 & 16.7 & 0 & 5.4 & $T$ & 5.4 & 5 & & $<31$ \\
\hline 19/Mar/2008 & 3.3 & 2 & 2.7 & 15.3 & 0 & 5.2 & $\mathrm{~T}$ & 5.2 & 3 & 34 & 48 \\
\hline 20/Mar/2008 & 2.7 & -2.8 & -0.1 & 18.1 & 0 & 0 & 0 & 0 & 2 & 31 & 70 \\
\hline 21/Mar/2008 & 0.6 & -4.8 & -2.1 & 20.1 & 0 & 0 & 0 & 0 & 2 & 33 & 41 \\
\hline 22/Mar/2008 & 0.9 & -7.5 & -3.3 & 21.3 & 0 & 0 & 0 & 0 & 2 & 33 & 37 \\
\hline 23/Mar/2008 & 0.8 & -6.6 & -2.9 & 20.9 & 0 & 0 & 0.2 & 0.2 & 2 & & $<31$ \\
\hline 24/Mar/2008 & 0 & -9.3 & -4.7 & 22.7 & 0 & 0 & 1.4 & 1.4 & 3 & & $<31$ \\
\hline 25/Mar/2008 & 3.7 & -6.1 & -1.2 & 19.2 & 0 & 0.4 & 5 & 5.4 & 3 & 21 & 61 \\
\hline 26/Mar/2008 & 5 & -0.7 & 2.2 & 15.8 & 0 & 0 & 0 & 0 & 3 & 31 & 50 \\
\hline 27/Mar/2008 & 5.9 & -1.7 & 2.1 & 15.9 & 0 & 0 & 0 & 0 & 2 & & $<31$ \\
\hline 28/Mar/2008 & 3.8 & -3.7 & 0.1 & 17.9 & 0 & 0 & $T$ & $T$ & 1 & 34 & 37 \\
\hline 29/Mar/2008 & 1.9 & -5.7 & -1.9 & 19.9 & 0 & 0 & 0 & 0 & $T$ & & $<31$ \\
\hline $30 / \mathrm{Mar} / 2008$ & 4.2 & -3.1 & 0.6 & 17.4 & 0 & $T$ & 0 & $T$ & $T$ & 10 & 48 \\
\hline $31 / \mathrm{Mar} / 2008$ & 7.2 & 2.5 & 4.9 & 13.1 & 0 & 8.8 & 0 & 8.8 & $T$ & & $<31$ \\
\hline $01 / \mathrm{Apr} / 2008$ & 15.3 & -0.9 & 7.2 & 10.8 & 0 & 1.2 & 0 & 1.2 & $T$ & 28 & 83 \\
\hline $02 / \mathrm{Apr} / 2008$ & 4.6 & -4.5 & 0.1 & 17.9 & 0 & 0 & 0 & 0 & $T$ & 33 & 33 \\
\hline
\end{tabular}




\begin{tabular}{|c|c|c|c|c|c|c|c|c|c|c|c|}
\hline $03 / \mathrm{Apr} / 2008$ & 9.8 & -2.4 & 3.7 & 14.3 & 0 & 0 & 0 & 0 & 0 & & $<31$ \\
\hline $04 / \mathrm{Apr} / 2008$ & 5.5 & 1.3 & 3.4 & 14.6 & 0 & 7.6 & 1 & 8.6 & 0 & & $<31$ \\
\hline $05 / \mathrm{Apr} / 2008$ & 12 & -0.2 & 5.9 & 12.1 & 0 & 0 & 0 & 0 & 0 & & $<31$ \\
\hline $06 / \mathrm{Apr} / 2008$ & 13 & 0.6 & 6.8 & 11.2 & 0 & 0 & 0 & 0 & 0 & 9 & 41 \\
\hline $07 / \mathrm{Apr} / 2008$ & 12.5 & 4.7 & 8.6 & 9.4 & 0 & 0 & 0 & 0 & 0 & 10 & 33 \\
\hline $08 / \mathrm{Apr} / 2008$ & 16.7 & 6.9 & 11.8 & 6.2 & 0 & 0 & 0 & 0 & 0 & & $<31$ \\
\hline $09 / \mathrm{Apr} / 2008$ & 19.5 & 5 & 12.3 & 5.7 & 0 & 2.6 & 0 & 2.6 & 0 & 27 & 57 \\
\hline $10 / \mathrm{Apr} / 2008$ & 11.6 & 2.3 & 7 & 11 & 0 & 0.4 & 0 & 0.4 & 0 & 8 & 44 \\
\hline $11 / \mathrm{Apr} / 2008$ & 6 & 2.3 & 4.2 & 13.8 & 0 & 24.2 & 0 & 24.2 & 0 & 10 & 57 \\
\hline $12 / \mathrm{Apr} / 2008$ & 9.3 & 2.7 & 6 & 12 & 0 & 4.2 & 0 & 4.2 & 0 & 29 & 35 \\
\hline $13 / \mathrm{Apr} / 2008$ & 7.3 & 0.9 & 4.1 & 13.9 & 0 & $T$ & $T$ & $\mathrm{~T}$ & 0 & 33 & 41 \\
\hline $14 / \mathrm{Apr} / 2008$ & 10.3 & 0.5 & 5.4 & 12.6 & 0 & 0 & 0 & 0 & 0 & 36 & 35 \\
\hline $15 / \mathrm{Apr} / 2008$ & 13.5 & -2.3 & 5.6 & 12.4 & 0 & 0 & 0 & 0 & 0 & & $<31$ \\
\hline $16 / \mathrm{Apr} / 2008$ & 18.9 & 3.8 & 11.4 & 6.6 & 0 & 0 & 0 & 0 & 0 & 21 & 41 \\
\hline $17 / \mathrm{Apr} / 2008$ & 23.3 & 5.6 & 14.5 & 3.5 & 0 & 0 & 0 & 0 & 0 & 23 & 37 \\
\hline $18 / \mathrm{Apr} / 2008$ & 23.2 & 10 & 16.6 & 1.4 & 0 & 0 & 0 & 0 & 0 & & $<31$ \\
\hline $19 / \mathrm{Apr} / 2008$ & 24.3 & 7.9 & 16.1 & 1.9 & 0 & 0 & 0 & 0 & 0 & 10 & 46 \\
\hline $20 / \mathrm{Apr} / 2008$ & 23.5 & 9.5 & 16.5 & 1.5 & 0 & 0 & 0 & 0 & 0 & & $<31$ \\
\hline $21 / \mathrm{Apr} / 2008$ & 20.9 & 12.7 & 16.8 & 1.2 & 0 & 0 & 0 & 0 & 0 & & $<31$ \\
\hline $22 / \mathrm{Apr} / 2008$ & 20.9 & 10.3 & 15.6 & 2.4 & 0 & 0 & 0 & 0 & 0 & & $<31$ \\
\hline $23 / \mathrm{Apr} / 2008$ & 23.7 & 9.5 & 16.6 & 1.4 & 0 & 1.8 & 0 & 1.8 & 0 & 30 & 52 \\
\hline $24 / \mathrm{Apr} / 2008$ & 18.6 & 5.6 & 12.1 & 5.9 & 0 & 0 & 0 & 0 & 0 & & $<31$ \\
\hline $25 / \mathrm{Apr} / 2008$ & 17.4 & 11 & 14.2 & 3.8 & 0 & 0 & 0 & 0 & 0 & & $<31$ \\
\hline 26/Apr/2008 & 23.8 & 8.4 & 16.1 & 1.9 & 0 & 0 & 0 & 0 & 0 & 23 & 57 \\
\hline $27 / \mathrm{Apr} / 2008$ & 19.6 & 7.1 & 13.4 & 4.6 & 0 & 0 & 0 & 0 & 0 & 16 & 37 \\
\hline $28 / \mathrm{Apr} / 2008$ & 9.1 & 0.9 & 5 & 13 & 0 & 11.6 & 0 & 11.6 & 0 & 36 & 44 \\
\hline 29/Apr/2008 & 10.3 & -2 & 4.2 & 13.8 & 0 & 0 & 0 & 0 & 0 & 32 & 41 \\
\hline $30 / \mathrm{Apr} / 2008$ & 11.6 & -1.9 & 4.9 & 13.1 & 0 & 0 & 0 & 0 & 0 & 28 & 44 \\
\hline
\end{tabular}




\begin{tabular}{|c|c|c|c|c|c|c|c|c|c|c|c|}
\hline \multicolumn{12}{|c|}{ Daily Data Report for Winter 2008-2009 } \\
\hline \multicolumn{3}{|c|}{ Environment Canada } & \multicolumn{5}{|c|}{$\begin{array}{l}\text { National Climate Data and Information } \\
\text { Archive }\end{array}$} & \multicolumn{4}{|c|}{ www.climate.weatheroffice.gc.ce } \\
\hline Day & $\begin{array}{c}\text { Max } \\
\text { Temp }\end{array}$ & $\begin{array}{c}\text { Min } \\
\text { Temp }\end{array}$ & $\begin{array}{l}\text { Mean } \\
\text { Temp }\end{array}$ & $\begin{array}{l}\text { Heat } \\
\text { Deg } \\
\text { Days }\end{array}$ & $\begin{array}{l}\text { Cool } \\
\text { Deg } \\
\text { Days }\end{array}$ & $\begin{array}{l}\text { Total } \\
\text { Rain }\end{array}$ & $\begin{array}{l}\text { Total } \\
\text { Snow }\end{array}$ & $\begin{array}{l}\text { Total } \\
\text { Precip }\end{array}$ & $\begin{array}{c}\text { Snow } \\
\text { on } \\
\text { Grnd }\end{array}$ & $\begin{array}{c}\text { Dir of } \\
\text { Max } \\
\text { Gust }\end{array}$ & $\begin{array}{l}\text { Spd of } \\
\text { Max } \\
\text { Gust }\end{array}$ \\
\hline & ${ }^{\circ} \mathrm{C}$ & ${ }^{\circ} \mathrm{C}$ & ${ }^{\circ} \mathrm{C}$ & ${ }^{\circ} \mathrm{C}$ & ${ }^{\circ} \mathrm{C}$ & $\mathrm{mm}$ & $\mathrm{cm}$ & $\mathrm{mm}$ & $\mathrm{cm}$ & 10's Deg & $\mathrm{km} / \mathrm{h}$ \\
\hline $31 /$ Oct/2008 & 19.5 & 6.8 & 9.9 & 4.8 & 0 & 0 & 0 & 0 & 0 & 25 & 39 \\
\hline $01 /$ Nov/2008 & 9.1 & -0.6 & 4.3 & 13.7 & 0 & 0 & 0 & 0 & 0 & 36 & 32 \\
\hline $02 / \mathrm{Nov} / 2008$ & 6.8 & -2.5 & 2.2 & 15.8 & 0 & 0 & 0 & 0 & 0 & 12 & 32 \\
\hline \begin{tabular}{|l}
$03 / \mathrm{Nov} / 2008$ \\
\end{tabular} & 16 & 2.5 & 9.3 & 8.7 & 0 & 8.2 & 0 & 8.2 & 0 & & $<31$ \\
\hline $04 / \mathrm{Nov} / 2008$ & 18.1 & 6.8 & 12.5 & 5.5 & 0 & 0 & 0 & 0 & 0 & & $<31$ \\
\hline \begin{tabular}{|l}
$05 / \mathrm{Nov} / 2008$ \\
\end{tabular} & 17.6 & 6.7 & 12.2 & 5.8 & 0 & 0 & 0 & 0 & 0 & & $<31$ \\
\hline 06/Nov/2008 & 17.8 & 3.4 & 10.6 & 7.4 & 0 & 0 & 0 & 0 & 0 & & $<31$ \\
\hline $07 /$ Nov/2008 & 17 & 5.1 & 11.1 & 6.9 & 0 & 4.4 & 0 & 4.4 & 0 & & $<31$ \\
\hline \begin{tabular}{|l}
$08 / \mathrm{Nov} / 2008$ \\
\end{tabular} & 11.2 & 2.7 & 7 & 11 & 0 & 0.8 & 0 & 0.8 & 0 & 21 & 46 \\
\hline 09/Nov/2008 & 7.3 & 0.2 & 3.8 & 14.2 & 0 & $T$ & 0 & $\mathrm{~T}$ & 0 & 25 & 44 \\
\hline $10 /$ Nov/2008 & 4.6 & -0.7 & 2 & 16 & 0 & $T$ & $T$ & $T$ & 0 & 26 & 54 \\
\hline $11 /$ Nov/2008 & 5.8 & 0 & 2.9 & 15.1 & 0 & 0 & 0 & 0 & 0 & 27 & 33 \\
\hline $12 / \mathrm{Nov} / 2008$ & 7.4 & 0.9 & 4.2 & 13.8 & 0 & 0 & 0 & 0 & 0 & & $<31$ \\
\hline $13 / \mathrm{Nov} / 2008$ & 11.9 & 5.9 & 8.9 & 9.1 & 0 & 8.4 & 0 & 8.4 & 0 & 22 & 37 \\
\hline 14/Nov/2008 & 14.6 & 8.2 & 11.4 & 6.6 & 0 & 2.6 & 0 & 2.6 & 0 & 20 & 35 \\
\hline $15 /$ Nov/2008 & 9.4 & 0.9 & 5.2 & 12.8 & 0 & 28.4 & $T$ & 28.4 & 0 & 35 & 78 \\
\hline $16 /$ Nov/2008 & 4.2 & -1.1 & 1.6 & 16.4 & 0 & 1.2 & $T$ & 1.2 & 0 & 30 & 54 \\
\hline $17 /$ Nov/2008 & 2.1 & -4.4 & -1.2 & 19.2 & 0 & 0 & $T$ & $T$ & 0 & 36 & 37 \\
\hline $18 / \mathrm{Nov} / 2008$ & 0.1 & -6.7 & -3.3 & 21.3 & 0 & 0 & $T$ & $T$ & $T$ & 35 & 32 \\
\hline $19 / \mathrm{Nov} / 2008$ & -1.2 & -8.6 & -4.9 & 22.9 & 0 & 0 & 6.2 & 3 & 0 & & $<31$ \\
\hline $20 /$ Nov/2008 & -0.3 & -6.1 & -3.2 & 21.2 & 0 & 0 & 0.4 & 0.4 & 7 & & $<31$ \\
\hline $21 / \mathrm{Nov} / 2008$ & -3.8 & -10.6 & -7.2 & 25.2 & 0 & 0 & 0 & 0 & 2 & 32 & 35 \\
\hline $22 /$ Nov/2008 & -3.5 & -10.6 & -7.1 & 25.1 & 0 & 0 & 0 & 0 & 2 & & $<31$ \\
\hline $23 /$ Nov/2008 & 0.5 & -9.7 & -4.6 & 22.6 & 0 & 0 & 0 & 0 & 2 & & $<31$ \\
\hline $24 /$ Nov/2008 & 3.9 & $\begin{array}{l}-1.3 \\
\end{array}$ & 1.3 & 16.7 & 0 & 5.8 & 0.4 & 6.2 & 1 & 12 & 37 \\
\hline $25 /$ Nov/2008 & 4.5 & 0.9 & 2.7 & 15.3 & 0 & 1.2 & $T$ & 1.2 & 0 & 22 & 32 \\
\hline $26 / \mathrm{Nov} / 2008$ & 3.1 & 0.3 & 1.7 & 16.3 & 0 & 0.4 & 0.2 & 0.6 & $T$ & 27 & 48 \\
\hline $27 /$ Nov/2008 & 3.1 & 0.6 & 1.9 & 16.1 & 0 & 0 & $T$ & $T$ & 0 & 25 & 39 \\
\hline $28 / \mathrm{Nov} / 2008$ & 3.8 & -0.1 & 1.9 & 16.1 & 0 & 0.4 & 0.4 & 0.8 & $T$ & 26 & 56 \\
\hline $29 / \mathrm{Nov} / 2008$ & 4.8 & -2.2 & 1.3 & 16.7 & 0 & 0 & 0 & 0 & 0 & 24 & 32 \\
\hline $30 /$ Nov/2008 & 3.8 & -4 & -0.1 & 18.1 & 0 & 8.1 & 5.5 & 13.6 & 0 & 10 & 57 \\
\hline $01 / \mathrm{Dec} / 2008$ & 3.4 & -0.9 & 1.3 & 16.7 & 0 & 3.2 & 0.4 & 3.6 & 0 & 21 & 46 \\
\hline $02 / \mathrm{Dec} / 2008$ & 0.6 & -1.6 & -0.5 & 18.5 & 0 & 0 & $T$ & $T$ & $T$ & 26 & 44 \\
\hline $03 / \mathrm{Dec} / 2008$ & 6.4 & -1 & 2.7 & 15.3 & 0 & 0.4 & 0 & 0.4 & 0 & 20 & 44 \\
\hline 04/Dec/2008 & 4.8 & -4.3 & 0.3 & 17.7 & 0 & 1 & $T$ & 1 & 0 & 27 & 56 \\
\hline 05/Dec/2008 & -2.2 & -8 & -5.1 & 23.1 & 0 & 0 & $T$ & $T$ & 0 & 26 & 52 \\
\hline $06 / \mathrm{Dec} / 2008$ & -1.7 & -6.6 & -4.2 & 22.2 & 0 & 0 & 2.2 & 1.8 & $T$ & 19 & 37 \\
\hline 07/Dec/2008 & -2.1 & -12.7 & -7.4 & 25.4 & 0 & 0 & $T$ & $T$ & 2 & 30 & 63 \\
\hline 08/Dec/2008 & -2.6 & -11.2 & -6.9 & 24.9 & 0 & 0 & 3.4 & 1.4 & 2 & & $<31$ \\
\hline 09/Dec/2008 & 3.7 & -3.4 & 0.2 & 17.8 & 0 & 6.4 & 6 & 12.4 & 6 & & $<31$ \\
\hline $10 / \mathrm{Dec} / 2008$ & 2.6 & -9.6 & -3.5 & 21.5 & 0 & 3.6 & 0.4 & 4.2 & 1 & 34 & 44 \\
\hline $11 / \mathrm{Dec} / 2008$ & -1.8 & -10.1 & -6 & 24 & 0 & 0 & 0 & 0 & 1 & & $<31$ \\
\hline $12 / \mathrm{Dec} / 2008$ & -1.4 & -11.9 & -6.7 & 24.7 & 0 & 0 & $T$ & $T$ & 1 & 29 & 41 \\
\hline $13 / \mathrm{Dec} / 2008$ & 1.1 & -12.9 & -5.9 & 23.9 & 0 & 0 & 0.2 & 0.2 & 1 & 20 & 39 \\
\hline 14/Dec/2008 & 5.1 & 0.6 & 2.9 & 15.1 & 0 & 1 & $T$ & 1 & 1 & 22 & 37 \\
\hline
\end{tabular}




\begin{tabular}{|c|c|c|c|c|c|c|c|c|c|c|c|}
\hline 15/Dec/2008 & 10.6 & -7.3 & 1.7 & 16.3 & 0 & 3.8 & $T$ & 3.8 & 0 & 24 & 74 \\
\hline $16 / \mathrm{Dec} / 2008$ & -3.3 & -7.6 & -5.5 & 23.5 & 0 & 0 & 4.4 & 4 & $\mathrm{~T}$ & & $<31$ \\
\hline 17/Dec/2008 & -0.1 & -5.8 & -3 & 21 & 0 & 0 & 5.4 & 4.6 & 8 & 28 & 39 \\
\hline 18/Dec/2008 & -2.2 & -8.4 & -5.3 & 23.3 & 0 & 0 & 0 & 0 & 7 & 26 & 33 \\
\hline 19/Dec/2008 & -4.2 & -14.5 & -9.4 & 27.4 & 0 & 0 & 16 & 15.2 & 7 & 3 & 57 \\
\hline 20/Dec/2008 & -10.4 & -17.7 & -14.1 & 32.1 & 0 & 0 & 0.4 & 0.2 & 22 & 7 & 32 \\
\hline 21/Dec/2008 & -3.6 & -13.7 & -8.7 & 26.7 & 0 & 0 & 5.4 & 5.4 & 24 & 25 & 69 \\
\hline $22 / \mathrm{Dec} / 2008$ & -7.1 & -13.5 & -10.3 & 28.3 & 0 & 0 & $T$ & $T$ & 24 & 30 & 59 \\
\hline 23/Dec/2008 & -1.4 & -11.7 & -6.6 & 24.6 & 0 & 0 & 11 & 11.6 & 23 & 18 & 35 \\
\hline 24/Dec/2008 & 6.1 & -1.5 & 2.3 & 15.7 & 0 & 10.8 & 1.8 & 12.6 & 36 & 27 & 93 \\
\hline 25/Dec/2008 & 1.2 & -4.6 & -1.7 & 19.7 & 0 & 0 & 0.2 & 0.2 & 31 & 28 & 74 \\
\hline 26/Dec/2008 & 2.5 & -4.9 & -1.2 & 19.2 & 0 & $T$ & 2.2 & 1.8 & 30 & & $<31$ \\
\hline 27/Dec/2008 & 14.2 & 1.4 & 7.8 & 10.2 & 0 & 9 & 0 & 9 & 22 & 20 & 39 \\
\hline $28 / \mathrm{Dec} / 2008$ & 15.9 & 0.1 & 8 & 10 & 0 & 0.8 & 0 & 0.8 & 2 & 25 & 93 \\
\hline 29/Dec/2008 & 5.1 & -2.2 & 1.5 & 16.5 & 0 & $T$ & $T$ & $T$ & $T$ & 30 & 85 \\
\hline $30 / \mathrm{Dec} / 2008$ & -0.5 & -5.9 & -3.2 & 21.2 & 0 & 0 & 3.8 & 3.4 & $T$ & 29 & 72 \\
\hline $31 / \mathrm{Dec} / 2008$ & -5.8 & -14.3 & -10.1 & 28.1 & 0 & 0 & 1.6 & 1.2 & 5 & 31 & 57 \\
\hline $01 / \operatorname{Jan} / 2009$ & -3.8 & -15.6 & -9.7 & 27.7 & 0 & 0 & 0 & 0 & 2 & & $<31$ \\
\hline $02 / \operatorname{Jan} / 2009$ & 0.7 & -4.7 & -2 & 20 & 0 & 0 & 1.2 & 0.6 & 2 & 28 & 48 \\
\hline $03 / \operatorname{Jan} / 2009$ & -1.9 & -11.8 & -6.9 & 24.9 & 0 & 0 & 0 & 0 & 2 & 28 & 35 \\
\hline $04 / \operatorname{Jan} / 2009$ & -0.7 & -12.2 & -6.5 & 24.5 & 0 & $T$ & 0 & $T$ & 2 & & $<31$ \\
\hline $05 / \operatorname{Jan} / 2009$ & 0.6 & -7.7 & -3.6 & 21.6 & 0 & $T$ & 0 & $\mathrm{~T}$ & 1 & 27 & 44 \\
\hline $06 / \operatorname{Jan} / 2009$ & -0.6 & -10 & -5.3 & 23.3 & 0 & $T$ & 3.6 & 3.4 & 1 & 11 & 33 \\
\hline $07 / \operatorname{Jan} / 2009$ & 0.7 & -2.8 & -1.1 & 19.1 & 0 & 1 & 9 & 10 & 5 & 25 & 46 \\
\hline $08 / \operatorname{Jan} / 2009$ & -2.8 & -12 & -7.4 & 25.4 & 0 & 0 & 0.2 & 0.2 & 11 & 30 & 48 \\
\hline $09 / \mathrm{Jan} / 2009$ & -6 & -12.2 & -9.1 & 27.1 & 0 & 0 & $T$ & $T$ & 11 & & $<31$ \\
\hline $10 / \operatorname{Jan} / 2009$ & -6.8 & -14.9 & -10.9 & 28.9 & 0 & 0 & 3.8 & 3.4 & 11 & 1 & 39 \\
\hline 11/Jan/2009 & -6.3 & -12.8 & -9.6 & 27.6 & 0 & 0 & 0.2 & 0.2 & 14 & 36 & 33 \\
\hline $12 / \mathrm{Jan} / 2009$ & -3.5 & -10.6 & -7.1 & 25.1 & 0 & 0 & 0 & 0 & 14 & 27 & 35 \\
\hline 13/Jan/2009 & 1.1 & -16.9 & -7.9 & 25.9 & 0 & 0 & 4 & 4.6 & 15 & 31 & 65 \\
\hline $14 / \operatorname{Jan} / 2009$ & -13.1 & -22.1 & -17.6 & 35.6 & 0 & 0 & 0.8 & 0.8 & 18 & & $<31$ \\
\hline $15 / \operatorname{Jan} / 2009$ & -10.8 & -19.3 & -15.1 & 33.1 & 0 & 0 & 0.6 & 0.6 & 18 & 26 & 33 \\
\hline 16/Jan/2009 & -12.7 & -18 & -15.4 & 33.4 & 0 & 0 & 0 & 0 & 18 & 26 & 50 \\
\hline $17 / \mathrm{Jan} / 2009$ & -6.9 & -20 & -13.5 & 31.5 & 0 & 0 & 4.8 & 4 & 18 & 14 & 37 \\
\hline 18/Jan/2009 & -3 & -8.6 & -5.8 & 23.8 & 0 & 0 & 2.8 & 2.8 & 21 & 14 & 33 \\
\hline $19 / \operatorname{Jan} / 2009$ & -5.6 & -11.6 & -8.6 & 26.6 & 0 & 0 & 0.8 & 0.8 & 24 & & $<31$ \\
\hline $20 / \operatorname{Jan} / 2009$ & -10.2 & -17.5 & -13.9 & 31.9 & 0 & 0 & $T$ & $T$ & 24 & 36 & 44 \\
\hline $21 / \operatorname{Jan} / 2009$ & -5.5 & -19 & -12.3 & 30.3 & 0 & 0 & $\mathrm{~T}$ & $T$ & 24 & 27 & 41 \\
\hline $22 / \operatorname{Jan} / 2009$ & -1.9 & -6 & -4 & 22 & 0 & 0 & $T$ & $T$ & 24 & & $<31$ \\
\hline 23/Jan/2009 & 3.6 & -6.8 & -1.6 & 19.6 & 0 & 0 & $T$ & $T$ & 24 & 30 & 63 \\
\hline $24 / \operatorname{Jan} / 2009$ & -6.7 & -19.2 & -13 & 31 & 0 & 0 & 0 & 0 & 21 & 31 & 46 \\
\hline $25 / \operatorname{Jan} / 2009$ & -8.9 & -15.6 & -12.3 & 30.3 & 0 & 0 & 0 & 0 & 21 & 25 & 37 \\
\hline $26 / \mathrm{Jan} / 2009$ & -8.8 & -16.9 & -12.9 & 30.9 & 0 & 0 & 0 & 0 & 21 & 26 & 33 \\
\hline $27 / \mathrm{Jan} / 2009$ & -4 & -13.8 & -8.9 & 26.9 & 0 & 0 & $T$ & $T$ & 21 & 11 & 33 \\
\hline $28 / \operatorname{Jan} / 2009$ & -3.4 & -8.2 & -5.8 & 23.8 & 0 & 0 & 13.4 & 12.6 & 23 & $M$ & $M$ \\
\hline $29 / \operatorname{Jan} / 2009$ & -3.1 & -10.2 & -6.7 & 24.7 & 0 & 0 & 0.4 & 0.4 & 32 & 22 & 35 \\
\hline $30 / \mathrm{Jan} / 2009$ & -3.2 & -10.8 & -7 & 25 & 0 & 0 & $T$ & $T$ & 32 & 27 & 48 \\
\hline $31 / \operatorname{Jan} / 2009$ & -4.7 & -16.7 & -10.7 & 28.7 & 0 & 0 & 0.4 & $T$ & 32 & 23 & 37 \\
\hline $01 / \mathrm{Feb} / 2009$ & 4.4 & -4.8 & -0.2 & 18.2 & 0 & 0 & 0 & 0 & 32 & 26 & 52 \\
\hline $02 / \mathrm{Feb} / 2009$ & 2 & -7.9 & -3 & 21 & 0 & 0 & 0 & 0 & 28 & & $<31$ \\
\hline $03 / \mathrm{Feb} / 2009$ & -3.8 & -10.5 & -7.2 & 25.2 & 0 & 0 & 7.4 & 6.2 & 27 & 8 & 37 \\
\hline $04 / \mathrm{Feb} / 2009$ & -10.2 & -18 & -14.1 & 32.1 & 0 & 0 & 1.6 & 1 & 35 & 35 & 35 \\
\hline $05 / \mathrm{Feb} / 2009$ & -9 & -22.2 & -15.6 & 33.6 & 0 & 0 & $T$ & $T$ & 35 & & $<31$ \\
\hline $06 / \mathrm{Feb} / 2009$ & -2 & -11.8 & -6.9 & 24.9 & 0 & 0 & 0 & 0 & 35 & & $<31$ \\
\hline $07 / \mathrm{Feb} / 2009$ & 7.9 & -8.3 & -0.2 & 18.2 & 0 & 0 & 0 & 0 & 32 & 24 & 70 \\
\hline
\end{tabular}




\begin{tabular}{|c|c|c|c|c|c|c|c|c|c|c|c|}
\hline $08 / \mathrm{Feb} / 2009$ & 4 & -4.8 & -0.4 & 18.4 & 0 & 0 & 0 & 0 & 9 & 30 & 57 \\
\hline $09 / \mathrm{Feb} / 2009$ & 3.2 & -6.2 & -1.5 & 19.5 & 0 & 0 & 0 & 0 & 6 & & $<31$ \\
\hline $10 / \mathrm{Feb} / 2009$ & 9.3 & -0.1 & 4.6 & 13.4 & 0 & $T$ & 0 & $T$ & 3 & 22 & 35 \\
\hline $11 / \mathrm{Feb} / 2009$ & 8.9 & 6.5 & 7.7 & 10.3 & 0 & 25.8 & 0 & 25.8 & 1 & & $<31$ \\
\hline $12 / \mathrm{Feb} / 2009$ & 7.8 & -2.1 & 2.9 & 15.1 & 0 & 11.8 & $T$ & 11.8 & $T$ & 29 & 85 \\
\hline 13/Feb/2009 & -0.9 & -7.4 & -4.2 & 22.2 & 0 & 0 & 0 & 0 & $T$ & 35 & 32 \\
\hline $14 / \mathrm{Feb} / 2009$ & -1.8 & -8.2 & -5 & 23 & 0 & 0 & 0 & 0 & $T$ & & $<31$ \\
\hline $15 / \mathrm{Feb} / 2009$ & 1.3 & -8.9 & -3.8 & 21.8 & 0 & 0 & 0 & 0 & $T$ & & $<31$ \\
\hline 16/Feb/2009 & 0.7 & -7.5 & -3.4 & 21.4 & 0 & 0 & 0 & 0 & $T$ & & $<31$ \\
\hline $17 / \mathrm{Feb} / 2009$ & 2.2 & -6.8 & -2.3 & 20.3 & 0 & 0 & 0 & 0 & $T$ & 22 & 32 \\
\hline $18 / \mathrm{Feb} / 2009$ & 1 & -0.8 & 0.1 & 17.9 & 0 & 0 & 8.2 & 12.4 & $T$ & & $<31$ \\
\hline 19/Feb/2009 & 1.3 & -7.9 & -3.3 & 21.3 & 0 & 0 & 0.4 & 0.4 & 3 & 27 & 59 \\
\hline $20 / \mathrm{Feb} / 2009$ & -2.6 & -8.8 & -5.7 & 23.7 & 0 & 0 & $T$ & $T$ & 3 & 29 & 70 \\
\hline $21 / \mathrm{Feb} / 2009$ & -0.5 & -11.2 & -5.9 & 23.9 & 0 & 0 & 4.6 & 3.6 & 2 & 12 & 37 \\
\hline $22 / \mathrm{Feb} / 2009$ & -2 & -8.3 & -5.2 & 23.2 & 0 & 0 & $T$ & $T$ & 5 & 25 & 54 \\
\hline $23 / \mathrm{Feb} / 2009$ & -6 & -11.4 & -8.7 & 26.7 & 0 & 0 & 0 & 0 & 4 & 34 & 59 \\
\hline 24/Feb/2009 & -3.2 & -15.1 & -9.2 & 27.2 & 0 & 0 & 0 & 0 & 4 & & $<31$ \\
\hline $25 / \mathrm{Feb} / 2009$ & 2.8 & -6.9 & -2.1 & 20.1 & 0 & 0.8 & 2.2 & 2.8 & 3 & & $<31$ \\
\hline $26 / \mathrm{Feb} / 2009$ & 6.5 & -0.5 & 3 & 15 & 0 & 3.8 & 0 & 3.8 & 1 & & $<31$ \\
\hline $27 / \mathrm{Feb} / 2009$ & 9.4 & -12 & -1.3 & 19.3 & 0 & 5.8 & $T$ & 5.8 & $T$ & 35 & 59 \\
\hline $28 / \mathrm{Feb} / 2009$ & -6.5 & -16.4 & -11.5 & 29.5 & 0 & 0 & 0 & 0 & $T$ & 36 & 35 \\
\hline 01/Mar/2009 & -4.2 & -12.5 & -8.4 & 26.4 & 0 & 0 & 0 & 0 & $T$ & 34 & 52 \\
\hline 02/Mar/2009 & -9.5 & -15.4 & -12.5 & 30.5 & 0 & 0 & 0 & 0 & $T$ & 35 & 52 \\
\hline 03/Mar/2009 & -3.9 & -15.7 & -9.8 & 27.8 & 0 & 0 & 0 & 0 & $T$ & & $<31$ \\
\hline 04/Mar/2009 & 1.6 & -12.5 & -5.5 & 23.5 & 0 & 0 & 0 & 0 & $T$ & & $<31$ \\
\hline 05/Mar/2009 & 5.6 & -7.1 & -0.8 & 18.8 & 0 & $T$ & 0 & $T$ & $T$ & & $<31$ \\
\hline 06/Mar/2009 & 18.9 & 1.3 & 10.1 & 7.9 & 0 & 0 & 0 & 0 & $T$ & 24 & 61 \\
\hline 07/Mar/2009 & 4.6 & -2 & 1.3 & 16.7 & 0 & 19.8 & 0 & 19.8 & $T$ & & $<31$ \\
\hline 08/Mar/2009 & 5.5 & 1.1 & 3.3 & 14.7 & 0 & 9.8 & $T$ & 9.8 & 0 & 9 & 59 \\
\hline 09/Mar/2009 & 4.4 & -0.5 & 2 & 16 & 0 & 1.4 & 0.6 & 2.2 & $T$ & 33 & 48 \\
\hline 10/Mar/2009 & 3.7 & 0.2 & 2 & 16 & 0 & 6.4 & 0 & 6.4 & 0 & 11 & 32 \\
\hline 11/Mar/2009 & 9.5 & -5.2 & 2.2 & 15.8 & 0 & 5.4 & $T$ & 5.4 & 0 & 33 & 82 \\
\hline $12 / \mathrm{Mar} / 2009$ & -2.1 & -9.5 & -5.8 & 23.8 & 0 & 0 & $T$ & $T$ & 0 & 31 & 41 \\
\hline 13/Mar/2009 & -0.7 & -10.3 & -5.5 & 23.5 & 0 & 0 & 0 & 0 & 0 & & $<31$ \\
\hline 14/Mar/2009 & 6.9 & -6.1 & 0.4 & 17.6 & 0 & 0 & 0 & 0 & 0 & & $<31$ \\
\hline 15/Mar/2009 & 9.6 & -3.8 & 2.9 & 15.1 & 0 & 0 & 0 & 0 & 0 & & $<31$ \\
\hline 16/Mar/2009 & 10 & -2.4 & 3.8 & 14.2 & 0 & 0 & 0 & 0 & 0 & & $<31$ \\
\hline 17/Mar/2009 & 11.8 & -1.8 & 5 & 13 & 0 & 0 & 0 & 0 & 0 & & $<31$ \\
\hline 18/Mar/2009 & 15 & 2.5 & 8.8 & 9.2 & 0 & $T$ & 0 & $T$ & 0 & 28 & 76 \\
\hline 19/Mar/2009 & 4.3 & -3.6 & 0.4 & 17.6 & 0 & 0 & 0 & 0 & 0 & 33 & 41 \\
\hline 20/Mar/2009 & 2.8 & -6.4 & -1.8 & 19.8 & 0 & 0 & 0 & 0 & 0 & & $<31$ \\
\hline 21/Mar/2009 & 5.9 & -5.7 & 0.1 & 17.9 & 0 & 0 & 0 & 0 & 0 & & $<31$ \\
\hline $22 / \mathrm{Mar} / 2009$ & 5.8 & -4.3 & 0.8 & 17.2 & 0 & 0 & 0 & 0 & 0 & 1 & 41 \\
\hline 23/Mar/2009 & 2.6 & -6.4 & -1.9 & 19.9 & 0 & 0 & 0 & 0 & 0 & 2 & 32 \\
\hline 24/Mar/2009 & 4 & -2.9 & 0.6 & 17.4 & 0 & 0 & 0 & 0 & 0 & 11 & 44 \\
\hline 25/Mar/2009 & 8.6 & 1.9 & 5.3 & 12.7 & 0 & 2.6 & 0 & 2.6 & 0 & 10 & 33 \\
\hline 26/Mar/2009 & 10.4 & 2 & 6.2 & 11.8 & 0 & $T$ & 0 & $T$ & 0 & 30 & 35 \\
\hline 27/Mar/2009 & 12.3 & -3 & 4.7 & 13.3 & 0 & 0 & 0 & 0 & 0 & & $<31$ \\
\hline 28/Mar/2009 & 13.2 & 0.3 & 6.8 & 11.2 & 0 & 0 & 0 & 0 & 0 & 9 & 50 \\
\hline 29/Mar/2009 & 10.8 & 2.6 & 6.7 & 11.3 & 0 & 22.6 & 0 & 22.6 & 0 & 23 & 61 \\
\hline $30 / \mathrm{Mar} / 2009$ & 5.6 & -2.7 & 1.5 & 16.5 & 0 & 0 & 0 & 0 & 0 & 30 & 54 \\
\hline 31/Mar/2009 & 5.6 & -3.1 & 1.3 & 16.7 & 0 & $T$ & 0 & $\mathrm{~T}$ & 0 & 9 & 44 \\
\hline $01 / \mathrm{Apr} / 2009$ & 14 & 2.5 & 8.3 & 9.7 & 0 & 1.8 & 0 & 1.8 & 0 & 24 & 70 \\
\hline $02 / \mathrm{Apr} / 2009$ & 15.1 & 1.3 & 8.2 & 9.8 & 0 & 0.2 & 0 & 0.2 & 0 & 10 & 48 \\
\hline 03/Apr/2009 & 10 & 3.1 & 6.6 & 11.4 & 0 & 40.2 & 0 & 40.2 & 0 & 29 & 74 \\
\hline
\end{tabular}




\begin{tabular}{|c|c|c|c|c|c|c|c|c|c|c|c|}
\hline 04/Apr/2009 & 5.6 & 2.5 & 4.1 & 13.9 & 0 & $\mathrm{~T}$ & 0 & $T$ & 0 & 30 & 80 \\
\hline 05/Apr/2009 & 12.1 & 0.3 & 6.2 & 11.8 & 0 & 0.2 & 0 & 0.2 & 0 & 34 & 37 \\
\hline 06/Apr/2009 & 4.8 & -3.3 & 0.8 & 17.2 & 0 & 13.8 & 3.8 & 17.8 & $T$ & 33 & 65 \\
\hline 07/Apr/2009 & -0.1 & -3.9 & -2 & 20 & 0 & 0 & $\mathrm{~T}$ & $T$ & 1 & 30 & 56 \\
\hline 08/Apr/2009 & 8.3 & -1.7 & 3.3 & 14.7 & 0 & 0 & $T$ & $T$ & $T$ & 27 & 63 \\
\hline 09/Apr/2009 & 11.7 & -1.7 & 5 & 13 & 0 & 0 & 0 & 0 & 0 & 30 & 52 \\
\hline 10/Apr/2009 & 10.7 & -0.6 & 5.1 & 12.9 & 0 & 0 & 0 & 0 & 0 & 2 & 33 \\
\hline 11/Apr/2009 & 8.9 & -0.8 & 4.1 & 13.9 & 0 & 0 & 0 & 0 & 0 & 33 & 56 \\
\hline 12/Apr/2009 & 6.7 & -2.5 & 2.1 & 15.9 & 0 & 0 & 0 & 0 & 0 & 35 & 46 \\
\hline 13/Apr/2009 & 6.8 & -3.9 & 1.5 & 16.5 & 0 & 0 & 0 & 0 & 0 & & $<31$ \\
\hline 14/Apr/2009 & 11.8 & 3.9 & 7.9 & 10.1 & 0 & 0 & 0 & 0 & 0 & 8 & 57 \\
\hline 15/Apr/2009 & 14.5 & 3.6 & 9.1 & 8.9 & 0 & 0 & 0 & 0 & 0 & 7 & 33 \\
\hline 16/Apr/2009 & 14.5 & 2.5 & 8.5 & 9.5 & 0 & 0 & 0 & 0 & 0 & & $<31$ \\
\hline 17/Apr/2009 & 20.9 & 3.9 & 12.4 & 5.6 & 0 & 0 & 0 & 0 & 0 & 31 & 41 \\
\hline 18/Apr/2009 & 21.2 & 8 & 14.6 & 3.4 & 0 & 0 & 0 & 0 & 0 & & $<31$ \\
\hline 19/Apr/2009 & 12.4 & 5.2 & 8.8 & 9.2 & 0 & $T$ & 0 & $T$ & 0 & 9 & 59 \\
\hline 20/Apr/2009 & 9.3 & 4.3 & 6.8 & 11.2 & 0 & 25.8 & 0 & 25.8 & 0 & 9 & 57 \\
\hline 21/Apr/2009 & 12 & 3.9 & 8 & 10 & 0 & 1 & 0 & 1 & 0 & 17 & 39 \\
\hline 22/Apr/2009 & 8 & 3.5 & 5.8 & 12.2 & 0 & $\mathrm{~T}$ & 0 & $\mathrm{~T}$ & 0 & 30 & 48 \\
\hline 23/Apr/2009 & 12 & 3.6 & 7.8 & 10.2 & 0 & $T$ & 0 & $T$ & 0 & 34 & 56 \\
\hline 24/Apr/2009 & 19.8 & 4.8 & 12.3 & 5.7 & 0 & 0 & 0 & 0 & 0 & 13 & 32 \\
\hline 25/Apr/2009 & 27.9 & 10.5 & 19.2 & 0 & 1.2 & 9.8 & 0 & 9.8 & 0 & 26 & 115 \\
\hline 26/Apr/2009 & 16.2 & 8.1 & 12.2 & 5.8 & 0 & 3 & 0 & 3 & 0 & 36 & 33 \\
\hline 27/Apr/2009 & 27.5 & 7 & 17.3 & 0.7 & 0 & 0 & 0 & 0 & 0 & 23 & 69 \\
\hline 28/Apr/2009 & 17.3 & 4.4 & 10.9 & 7.1 & 0 & 10.4 & 0 & 10.4 & 0 & 35 & 59 \\
\hline 29/Apr/2009 & 12.5 & 3.6 & 8.1 & 9.9 & 0 & 0 & 0 & 0 & 0 & 13 & 37 \\
\hline 30/Apr/2009 & 17.5 & 7.3 & 12.4 & 5.6 & 0 & 23.4 & 0 & 23.4 & 0 & 22 & 48 \\
\hline
\end{tabular}


Daily Data Report for Winter 2009-2010

\begin{tabular}{|c|c|c|c|c|c|c|c|c|c|c|c|}
\hline \multicolumn{3}{|c|}{ Environment Canada } & \multicolumn{5}{|c|}{$\begin{array}{l}\text { National Climate Data and Information } \\
\text { Archive }\end{array}$} & \multicolumn{4}{|c|}{ www.climate.weatheroffice.gc.ca } \\
\hline Day & $\begin{array}{l}\text { Max } \\
\text { Temp }\end{array}$ & $\begin{array}{l}\text { Min } \\
\text { Temp }\end{array}$ & $\begin{array}{l}\text { Mean } \\
\text { Temp }\end{array}$ & $\begin{array}{c}\text { Heat } \\
\text { Deg } \\
\text { Days }\end{array}$ & $\begin{array}{l}\text { Cool } \\
\text { Deg } \\
\text { Days }\end{array}$ & $\begin{array}{l}\text { Total } \\
\text { Rain }\end{array}$ & $\begin{array}{l}\text { Total } \\
\text { Snow }\end{array}$ & $\begin{array}{l}\text { Total } \\
\text { Precip }\end{array}$ & $\begin{array}{c}\text { Snow } \\
\text { on } \\
\text { Grnd }\end{array}$ & \begin{tabular}{|c|} 
Dir of \\
Max \\
Gust \\
\end{tabular} & $\begin{array}{l}\text { Spd of } \\
\text { Max } \\
\text { Gust }\end{array}$ \\
\hline & ${ }^{\circ} \mathrm{C}$ & ${ }^{\circ} \mathrm{C}$ & ${ }^{\circ} \mathrm{C}$ & ${ }^{\circ} \mathrm{C}$ & ${ }^{\circ} \mathrm{C}$ & $\mathrm{mm}$ & $\mathrm{cm}$ & $\mathrm{mm}$ & $\mathrm{cm}$ & 10's Deg & $\mathrm{km} / \mathrm{h}$ \\
\hline $01 / \mathrm{Nov} / 2009$ & 10.7 & 4.1 & 9.9 & 10.6 & 0 & 0 & 0 & 0 & 0 & 28 & 32 \\
\hline $02 / \mathrm{Nov} / 2009$ & 10.4 & 1.1 & 5.8 & 12.2 & 0 & 1.6 & 0 & 1.6 & 0 & & $<31$ \\
\hline $03 /$ Nov/2009 & 8.9 & 0.9 & 4.9 & 13.1 & 0 & $T$ & 0 & $\mathrm{~T}$ & 0 & 33 & 50 \\
\hline $04 /$ Nov/2009 & 6.2 & -1.2 & 2.5 & 15.5 & 0 & 1.8 & 0 & 1.8 & 0 & & $<31$ \\
\hline $05 /$ Nov/2009 & 7.5 & 1.3 & 4.4 & 13.6 & 0 & 1.6 & 0 & 1.6 & 0 & 32 & 69 \\
\hline $06 /$ Nov/2009 & 4.9 & -1.1 & 1.9 & 16.1 & 0 & 0 & 0 & 0 & 0 & & $<31$ \\
\hline $07 /$ Nov/2009 & 16.1 & 4.5 & 10.3 & 7.7 & 0 & 0 & 0 & 0 & 0 & 21 & 41 \\
\hline $08 /$ Nov/2009 & 18.1 & 4.7 & 11.4 & 6.6 & 0 & 0 & 0 & 0 & 0 & & $<31$ \\
\hline $09 /$ Nov/2009 & 19.1 & 3.9 & 11.5 & 6.5 & 0 & 0 & 0 & 0 & 0 & & $<31$ \\
\hline $10 /$ Nov/2009 & 13.5 & 3.3 & 8.4 & 9.6 & 0 & 0 & 0 & 0 & 0 & $M$ & $M$ \\
\hline $11 /$ Nov/2009 & 9 & -0.5 & 4.3 & 13.7 & 0 & 0 & 0 & 0 & 0 & & $<31$ \\
\hline $12 / \mathrm{Nov} / 2009$ & 9.6 & -1.8 & 3.9 & 14.1 & 0 & 0 & 0 & 0 & 0 & & $<31$ \\
\hline $13 /$ Nov/2009 & 11.1 & -1.5 & 4.8 & 13.2 & 0 & 0 & 0 & 0 & 0 & & $<31$ \\
\hline $14 / \mathrm{Nov} / 2009$ & 15.8 & 3.6 & 9.7 & 8.3 & 0 & 0 & 0 & 0 & 0 & & $<31$ \\
\hline $15 /$ Nov $/ 2009$ & 13.5 & 2 & 7.8 & 10.2 & 0 & 0 & 0 & 0 & 0 & 31 & 37 \\
\hline $16 /$ Nov/2009 & 8.8 & -0.2 & 4.3 & 13.7 & 0 & 0 & 0 & 0 & 0 & & $<31$ \\
\hline $17 /$ Nov $/ 2009$ & 7.5 & -2.3 & 2.6 & 15.4 & 0 & 0 & 0 & 0 & 0 & & $<31$ \\
\hline $18 /$ Nov $/ 2009$ & 11.3 & 0.1 & 5.7 & 12.3 & 0 & 0 & 0 & 0 & 0 & & $<31$ \\
\hline $19 /$ Nov/2009 & 10.2 & 2 & 6.1 & 11.9 & 0 & 12.6 & 0 & 12.6 & 0 & 25 & 37 \\
\hline $20 /$ Nov/2009 & 10.4 & 3.7 & 7.1 & 10.9 & 0 & 1.2 & 0 & 1.2 & 0 & 27 & 50 \\
\hline $21 /$ Nov/2009 & 11.7 & 3 & 7.4 & 10.6 & 0 & 0 & 0 & 0 & 0 & & $<31$ \\
\hline $22 / \mathrm{Nov} / 2009$ & 11 & 2.8 & 6.9 & 11.1 & 0 & 0 & 0 & 0 & 0 & & $<31$ \\
\hline $23 /$ Nov/2009 & 9.8 & 2.4 & 6.1 & 11.9 & 0 & 0 & 0 & 0 & 0 & & $<31$ \\
\hline $24 / \mathrm{Nov} / 2009$ & 7.8 & 6.2 & 7 & 11 & 0 & 1.2 & 0 & 1.2 & 0 & & $<31$ \\
\hline $25 /$ Nov/2009 & 10.6 & 7.5 & 9.1 & 8.9 & 0 & 6.2 & 0 & 6.2 & 0 & & $<31$ \\
\hline $26 /$ Nov/2009 & 9.5 & 1.3 & 5.4 & 12.6 & 0 & 0.4 & 0 & 0.4 & 0 & 23 & 35 \\
\hline $27 /$ Nov/2009 & 7.1 & 1.4 & 4.3 & 13.7 & 0 & 0.4 & 0 & 0.4 & 0 & 32 & 56 \\
\hline $28 /$ Nov/2009 & 6.5 & 0.2 & 3.4 & 14.6 & 0 & 0 & 0 & 0 & 0 & 30 & 33 \\
\hline $29 /$ Nov/2009 & 6.9 & -3 & 2 & 16 & 0 & 4.6 & 0 & 4.6 & 0 & & $<31$ \\
\hline $30 /$ Nov/2009 & 5.5 & -0.7 & 2.4 & 15.6 & 0 & 0.6 & 0 & 0.6 & 0 & 32 & 35 \\
\hline $01 / \mathrm{Dec} / 2009$ & 7 & 0.3 & 3.7 & 14.3 & 0 & 0 & 0.2 & 0.2 & $T$ & 24 & 44 \\
\hline $02 / \mathrm{Dec} / 2009$ & 10.2 & 0.2 & 5.2 & 12.8 & 0 & 15.6 & 0 & 15.6 & 0 & 9 & 46 \\
\hline $03 / \mathrm{Dec} / 2009$ & 7.6 & -0.6 & 3.5 & 14.5 & 0 & 5 & 0 & 5 & 0 & 30 & 54 \\
\hline $04 / \mathrm{Dec} / 2009$ & 3.3 & -3.8 & -0.3 & 18.3 & 0 & 0 & 0 & 0 & 0 & 24 & 50 \\
\hline $05 / \mathrm{Dec} / 2009$ & 0.9 & -5.7 & -2.4 & 20.4 & 0 & 0 & 0 & 0 & 0 & & $<31$ \\
\hline $06 / \mathrm{Dec} / 2009$ & 2.7 & -3.8 & -0.6 & 18.6 & 0 & 0 & $\mathrm{~T}$ & $T$ & $T$ & 23 & 41 \\
\hline $07 / \mathrm{Dec} / 2009$ & 1.6 & -2.7 & -0.6 & 18.6 & 0 & 0 & $\mathrm{~T}$ & $T$ & 0 & & $<31$ \\
\hline $08 / \mathrm{Dec} / 2009$ & 2.1 & -4.5 & -1.2 & 19.2 & 0 & 0 & $\mathrm{~T}$ & $T$ & 0 & 11 & 61 \\
\hline 09/Dec/2009 & 6.1 & -0.9 & 2.6 & 15.4 & 0 & 10.2 & 9.6 & 26.2 & 5 & 23 & 76 \\
\hline 10/Dec/2009 & -0.8 & -9.5 & -5.2 & 23.2 & 0 & 0 & 1.4 & 1 & 2 & 24 & 74 \\
\hline 11/Dec/2009 & -6.4 & -10.2 & -8.3 & 26.3 & 0 & 0 & $T$ & $T$ & 2 & 27 & 63 \\
\hline $12 / \mathrm{Dec} / 2009$ & 1.7 & -8.5 & -3.4 & 21.4 & 0 & 0 & $T$ & $T$ & 1 & 26 & 39 \\
\hline $13 / \mathrm{Dec} / 2009$ & 3 & -0.4 & 1.3 & 16.7 & 0 & 0.8 & $T$ & 0.8 & 1 & 19 & 35 \\
\hline 14/Dec/2009 & 3.8 & 0.4 & 2.1 & 15.9 & 0 & 2.6 & 0 & 2.6 & 1 & & $<31$ \\
\hline 15/Dec/2009 & 3 & -5 & -1 & 19 & 0 & 0 & 0.6 & 0.6 & $\mathrm{~T}$ & 31 & 50 \\
\hline
\end{tabular}




\begin{tabular}{|c|c|c|c|c|c|c|c|c|c|c|c|}
\hline 16/Dec/2009 & -3.6 & -6.3 & -5 & 23 & 0 & 0 & 0.6 & 0.4 & $\mathrm{~T}$ & 26 & 41 \\
\hline 17/Dec/2009 & -4.7 & -11.7 & -8.2 & 26.2 & 0 & 0 & $T$ & $T$ & $T$ & & $<31$ \\
\hline $18 / \mathrm{Dec} / 2009$ & -2.9 & -7.1 & -5 & 23 & 0 & 0 & $T$ & $T$ & $T$ & & $<31$ \\
\hline 19/Dec/2009 & -3.3 & -9.2 & -6.3 & 24.3 & 0 & 0 & 0 & 0 & $T$ & & $<31$ \\
\hline 20/Dec/2009 & 1.1 & -5.8 & -2.4 & 20.4 & 0 & 0 & $T$ & $T$ & $T$ & & $<31$ \\
\hline 21/Dec/2009 & -1.8 & -6.7 & -4.3 & 22.3 & 0 & 0 & $T$ & $\mathrm{~T}$ & $T$ & & $<31$ \\
\hline $22 / \mathrm{Dec} / 2009$ & -5.7 & -11.7 & -8.7 & 26.7 & 0 & 0 & $T$ & $T$ & $T$ & 34 & 32 \\
\hline 23/Dec/2009 & -3.3 & -9.9 & -6.6 & 24.6 & 0 & 0 & $T$ & $T$ & $T$ & 33 & 35 \\
\hline 24/Dec/2009 & 0.5 & -7.3 & -3.4 & 21.4 & 0 & 0 & 0.4 & 0.4 & $\mathrm{~T}$ & 10 & 44 \\
\hline 25/Dec/2009 & 3.7 & -0.1 & 1.8 & 16.2 & 0 & 15.6 & 0 & 15.6 & $T$ & 10 & 63 \\
\hline 26/Dec/2009 & 4.4 & -2.7 & 0.9 & 17.1 & 0 & 10.6 & 0 & 10.6 & 0 & 9 & 44 \\
\hline 27/Dec/2009 & 2 & -2.2 & -0.1 & 18.1 & 0 & 0 & $T$ & $T$ & 0 & 24 & 32 \\
\hline $28 / \mathrm{Dec} / 2009$ & -1.6 & -11.4 & -6.5 & 24.5 & 0 & 0 & 1 & 0.6 & $T$ & 31 & 70 \\
\hline 29/Dec/2009 & -5.2 & -15.7 & -10.5 & 28.5 & 0 & 0 & 0.4 & 0.2 & 1 & 31 & 56 \\
\hline $30 / \mathrm{Dec} / 2009$ & -1.2 & -8.8 & -5 & 23 & 0 & 0 & 0 & 0 & 1 & & $<31$ \\
\hline $31 / \mathrm{Dec} / 2009$ & 2.7 & -1.5 & 0.6 & 17.4 & 0 & 0.6 & $T$ & 0.6 & $T$ & & $<31$ \\
\hline $01 / \operatorname{Jan} / 2010$ & 0.9 & -10.4 & -4.8 & 22.8 & 0 & 0 & 1.6 & 1.2 & $T$ & 32 & 54 \\
\hline $02 / \operatorname{Jan} / 2010$ & -10.2 & -17.6 & -13.9 & 31.9 & 0 & 0 & $\mathrm{~T}$ & $T$ & 1 & 31 & 50 \\
\hline $03 / \operatorname{Jan} / 2010$ & -8.3 & -15.5 & -11.9 & 29.9 & 0 & 0 & 2 & 1.2 & 1 & 33 & 65 \\
\hline $04 / \operatorname{Jan} / 2010$ & -7.1 & -12.7 & -9.9 & 27.9 & 0 & 0 & 0.8 & 0.4 & 2 & 34 & 44 \\
\hline $05 / \mathrm{Jan} / 2010$ & -3.6 & -11.1 & -7.4 & 25.4 & 0 & 0 & 3 & 2 & 2 & 33 & 39 \\
\hline $06 / \mathrm{Jan} / 2010$ & -2.1 & -10.3 & -6.2 & 24.2 & 0 & 0 & $T$ & $T$ & 5 & 33 & 37 \\
\hline $07 / \mathrm{Jan} / 2010$ & -3 & -7.3 & -5.2 & 23.2 & 0 & 0 & $T$ & $T$ & 5 & & $<31$ \\
\hline $08 / \operatorname{Jan} / 2010$ & -7.3 & -11.7 & -9.5 & 27.5 & 0 & 0 & 1.4 & 0.8 & 5 & 34 & 46 \\
\hline 09/Jan/2010 & -8.7 & -14.6 & -11.7 & 29.7 & 0 & 0 & 0 & 0 & 5 & 36 & 46 \\
\hline $10 / \operatorname{Jan} / 2010$ & -3.8 & -15.6 & -9.7 & 27.7 & 0 & 0 & $T$ & $T$ & 4 & 24 & 46 \\
\hline $11 / \operatorname{Jan} / 2010$ & -4.7 & -7.8 & -6.3 & 24.3 & 0 & 0 & 1.4 & 1.2 & 3 & 23 & 39 \\
\hline $12 / \operatorname{Jan} / 2010$ & -5.7 & -9.1 & -7.4 & 25.4 & 0 & 0 & 0 & 0 & 4 & 35 & 35 \\
\hline $13 / \operatorname{Jan} / 2010$ & 0.4 & -6.1 & -2.9 & 20.9 & 0 & 0 & 0 & 0 & 4 & 24 & 44 \\
\hline $14 / \operatorname{Jan} / 2010$ & 4.8 & -6 & -0.6 & 18.6 & 0 & 0 & 0 & 0 & 3 & 22 & 33 \\
\hline $15 / \operatorname{Jan} / 2010$ & 4.1 & 1 & 2.6 & 15.4 & 0 & $T$ & 0 & $T$ & $\mathrm{~T}$ & & $<31$ \\
\hline $16 / \operatorname{Jan} / 2010$ & 2 & -3.2 & -0.6 & 18.6 & 0 & 0 & 0 & 0 & $\mathrm{~T}$ & 25 & 33 \\
\hline $17 / \operatorname{Jan} / 2010$ & 2.7 & -1.6 & 0.6 & 17.4 & 0 & 0 & 0 & 0 & 0 & & $<31$ \\
\hline $18 / \mathrm{Jan} / 2010$ & 1 & -2.9 & -1 & 19 & 0 & 0 & 0 & 0 & 0 & & $<31$ \\
\hline $19 / \operatorname{Jan} / 2010$ & 2 & -3.8 & -0.9 & 18.9 & 0 & 0 & 0.2 & 0.2 & 0 & 35 & 32 \\
\hline $20 / \mathrm{Jan} / 2010$ & -1.8 & -7.7 & -4.8 & 22.8 & 0 & 0 & 0 & 0 & $T$ & 34 & 35 \\
\hline $21 / \operatorname{Jan} / 2010$ & 0.9 & -8.9 & -4 & 22 & 0 & 0 & 0 & 0 & $T$ & 10 & 37 \\
\hline $22 / \operatorname{Jan} / 2010$ & 3.1 & -5.3 & -1.1 & 19.1 & 0 & 0 & 0 & 0 & 0 & 9 & 32 \\
\hline $23 / \operatorname{Jan} / 2010$ & 1.5 & -3.8 & -1.2 & 19.2 & 0 & 0 & 0 & 0 & 0 & & $<31$ \\
\hline $24 / \operatorname{Jan} / 2010$ & 6 & -1.3 & 2.4 & 15.6 & 0 & 6.2 & 0 & 6.2 & 0 & 12 & 32 \\
\hline $25 / \operatorname{Jan} / 2010$ & 6.7 & 0.2 & 3.5 & 14.5 & 0 & 10.8 & 0 & 10.8 & 0 & 26 & 48 \\
\hline $26 / \mathrm{Jan} / 2010$ & 0.3 & -1.9 & -0.8 & 18.8 & 0 & 0 & 0.2 & 0.2 & 0 & 26 & 56 \\
\hline $27 / \mathrm{Jan} / 2010$ & -1.9 & -5.8 & -3.9 & 21.9 & 0 & 0 & 0.2 & 0.2 & $T$ & 25 & 50 \\
\hline $28 / \mathrm{Jan} / 2010$ & -3.9 & -13.7 & -8.8 & 26.8 & 0 & 0 & $T$ & $T$ & $\mathrm{~T}$ & 32 & 74 \\
\hline $29 / J a n / 2010$ & -9.5 & -17.7 & -13.6 & 31.6 & 0 & 0 & $T$ & $T$ & $\mathrm{~T}$ & 31 & 46 \\
\hline $30 / \operatorname{Jan} / 2010$ & -9.4 & -19 & -14.2 & 32.2 & 0 & 0 & 0 & 0 & $T$ & & $<31$ \\
\hline $31 / \mathrm{Jan} / 2010$ & -4.1 & -13.5 & -8.8 & 26.8 & 0 & 0 & $T$ & $T$ & $T$ & 31 & 44 \\
\hline $01 / \mathrm{Feb} / 2010$ & -3.3 & -10.9 & -7.1 & 25.1 & 0 & 0 & $T$ & $T$ & $\mathrm{~T}$ & 27 & 50 \\
\hline $02 / \mathrm{Feb} / 2010$ & -1.2 & -9.9 & -5.6 & 23.6 & 0 & 0 & 2.6 & 2 & $\mathrm{~T}$ & & $<31$ \\
\hline $03 / \mathrm{Feb} / 2010$ & 0.6 & -6.1 & -2.8 & 20.8 & 0 & 0 & 0.4 & 0.4 & 2 & 29 & 48 \\
\hline $04 / \mathrm{Feb} / 2010$ & 0.4 & -10 & -4.8 & 22.8 & 0 & 0 & 0 & 0 & 2 & & $<31$ \\
\hline $05 / \mathrm{Feb} / 2010$ & 0.1 & -6.8 & -3.4 & 21.4 & 0 & 0 & 0 & 0 & 1 & 5 & 41 \\
\hline $06 / \mathrm{Feb} / 2010$ & -5.4 & -12 & -8.7 & 26.7 & 0 & 0 & 0 & 0 & 1 & 4 & 37 \\
\hline $07 / \mathrm{Feb} / 2010$ & -2.2 & -11.9 & -7.1 & 25.1 & 0 & 0 & 0 & 0 & $\mathrm{~T}$ & 35 & 37 \\
\hline $08 / \mathrm{Feb} / 2010$ & 0.9 & -11.4 & -5.3 & 23.3 & 0 & 0 & 0 & 0 & $\begin{array}{c}\mathrm{T} \\
\mathrm{T}\end{array}$ & 32 & 35 \\
\hline
\end{tabular}




\begin{tabular}{|c|c|c|c|c|c|c|c|c|c|c|c|}
\hline $09 / \mathrm{Feb} / 2010$ & -3.8 & -8.7 & -6.3 & 24.3 & 0 & 0 & 0.2 & 0.2 & $T$ & 7 & 35 \\
\hline $10 / \mathrm{Feb} / 2010$ & -3.2 & -7.6 & -5.4 & 23.4 & 0 & 0 & 4.4 & 3.2 & 3 & 33 & 54 \\
\hline 11/Feb/2010 & -1.4 & -9.7 & -5.6 & 23.6 & 0 & 0 & 0 & 0 & 3 & 29 & 37 \\
\hline $12 / \mathrm{Feb} / 2010$ & -0.5 & -11.5 & -6 & 24 & 0 & 0 & 0 & 0 & 2 & 28 & 35 \\
\hline 13/Feb/2010 & -1.2 & -9.6 & -5.4 & 23.4 & 0 & 0 & 0.6 & 0.6 & $T$ & 31 & 37 \\
\hline $14 / \mathrm{Feb} / 2010$ & -1.1 & -3.8 & -2.5 & 20.5 & 0 & 0 & $T$ & $T$ & 1 & 29 & 44 \\
\hline $15 / \mathrm{Feb} / 2010$ & -1.4 & -4.1 & -2.8 & 20.8 & 0 & 0 & $T$ & $T$ & $T$ & & $<31$ \\
\hline $16 / \mathrm{Feb} / 2010$ & 0.6 & -4.6 & -2 & 20 & 0 & 0 & 0.2 & 0.2 & $T$ & & $<31$ \\
\hline $17 / \mathrm{Feb} / 2010$ & 0.6 & -3.6 & -1.5 & 19.5 & 0 & 0 & 2.2 & 1.8 & $T$ & 31 & 50 \\
\hline $18 / \mathrm{Feb} / 2010$ & 1.4 & -2.4 & -0.5 & 18.5 & 0 & 0 & 0 & 0 & 1 & 32 & 48 \\
\hline $19 / \mathrm{Feb} / 2010$ & 4.1 & -2 & 1.1 & 16.9 & 0 & 0 & 0 & 0 & $T$ & 31 & 59 \\
\hline $20 / \mathrm{Feb} / 2010$ & 4.1 & -5.6 & -0.8 & 18.8 & 0 & 0 & 0 & 0 & $\mathrm{~T}$ & 29 & 33 \\
\hline $21 / \mathrm{Feb} / 2010$ & 4.9 & -5.7 & -0.4 & 18.4 & 0 & 0 & 0 & 0 & 0 & & $<31$ \\
\hline $22 / \mathrm{Feb} / 2010$ & 0.6 & -6.1 & -2.8 & 20.8 & 0 & 0 & 5 & 5 & 0 & 8 & 41 \\
\hline $23 / \mathrm{Feb} / 2010$ & 0.7 & -3.8 & -1.6 & 19.6 & 0 & $T$ & 0.6 & 0.6 & 5 & & $<31$ \\
\hline $24 / \mathrm{Feb} / 2010$ & 0.9 & -5.4 & -2.3 & 20.3 & 0 & 0 & $T$ & $T$ & 5 & & $<31$ \\
\hline $25 / \mathrm{Feb} / 2010$ & -0.4 & -7.5 & -4 & 22 & 0 & 0 & 3 & 2.8 & 3 & 34 & 61 \\
\hline $26 / \mathrm{Feb} / 2010$ & -0.1 & -6.3 & -3.2 & 21.2 & 0 & 0 & 6.4 & 6.2 & 7 & 34 & 72 \\
\hline $27 / \mathrm{Feb} / 2010$ & 2.2 & -0.7 & 0.8 & 17.2 & 0 & 0 & 1.8 & 1.8 & 8 & 32 & 41 \\
\hline $28 / \mathrm{Feb} / 2010$ & 3.1 & 0.2 & 1.7 & 16.3 & 0 & 0 & $T$ & $\mathrm{~T}$ & 4 & 34 & 35 \\
\hline $01 / \mathrm{Mar} / 2010$ & 2.5 & -1.3 & 0.6 & 17.4 & 0 & 0 & 0 & 0 & 1 & 34 & 46 \\
\hline $02 / \mathrm{Mar} / 2010$ & 3 & -3.4 & -0.2 & 18.2 & 0 & 0 & 0 & 0 & 1 & & $<31$ \\
\hline $03 / \mathrm{Mar} / 2010$ & 4.4 & -3.1 & 0.7 & 17.3 & 0 & 0 & 0 & 0 & $T$ & 36 & 32 \\
\hline $04 / \mathrm{Mar} / 2010$ & 3.8 & -4.3 & -0.3 & 18.3 & 0 & 0 & 0 & 0 & $T$ & 33 & 37 \\
\hline $05 / \mathrm{Mar} / 2010$ & 3.9 & -4.1 & -0.1 & 18.1 & 0 & 0 & 0 & 0 & $\mathrm{~T}$ & 35 & 35 \\
\hline $06 / \mathrm{Mar} / 2010$ & 9 & -4 & 2.5 & 15.5 & 0 & 0 & 0 & 0 & $T$ & & $<31$ \\
\hline $07 / \mathrm{Mar} / 2010$ & 11.3 & -2.7 & 4.3 & 13.7 & 0 & 0 & 0 & 0 & $T$ & 27 & 41 \\
\hline $08 / \mathrm{Mar} / 2010$ & 14.2 & -0.2 & 7 & 11 & 0 & 0 & 0 & 0 & $\mathrm{~T}$ & 29 & 46 \\
\hline 09/Mar/2010 & 13 & -0.1 & 6.5 & 11.5 & 0 & 0 & 0 & 0 & 0 & & $<31$ \\
\hline 10/Mar/2010 & 9 & -1.9 & 3.6 & 14.4 & 0 & $T$ & 0 & $T$ & 0 & M & $M$ \\
\hline $11 / \mathrm{Mar} / 2010$ & 12.2 & 5.1 & 8.7 & 9.3 & 0 & 0 & 0 & 0 & 0 & 9 & 44 \\
\hline $12 / \mathrm{Mar} / 2010$ & 7.5 & 5.1 & 6.3 & 11.7 & 0 & 21.6 & 0 & 21.6 & 0 & 9 & 54 \\
\hline $13 / \mathrm{Mar} / 2010$ & 6.7 & 4 & 5.4 & 12.6 & 0 & 20.6 & 0 & 20.6 & 0 & 7 & 78 \\
\hline 14/Mar/2010 & 5.8 & 3.3 & 4.6 & 13.4 & 0 & 4 & 0 & 4 & 0 & 8 & 70 \\
\hline 15/Mar/2010 & 13.2 & 3 & 8.1 & 9.9 & 0 & $T$ & 0 & $T$ & 0 & 4 & 33 \\
\hline 16/Mar/2010 & 16 & 0.9 & 8.5 & 9.5 & 0 & 0 & 0 & 0 & 0 & & $<31$ \\
\hline 17/Mar/2010 & 17.7 & 3.5 & 10.6 & 7.4 & 0 & 0 & 0 & 0 & 0 & & $<31$ \\
\hline 18/Mar/2010 & 18.7 & 3.2 & 11 & 7 & 0 & 0 & 0 & 0 & 0 & 27 & 46 \\
\hline 19/Mar/2010 & 19.1 & 3.1 & 11.1 & 6.9 & 0 & 0 & 0 & 0 & 0 & 24 & 50 \\
\hline 20/Mar/2010 & 5.3 & -1.2 & 2.1 & 15.9 & 0 & 0 & 0 & 0 & 0 & 35 & 32 \\
\hline 21/Mar/2010 & 5.3 & -1.6 & 1.9 & 16.1 & 0 & 0 & $\mathrm{~T}$ & T & $T$ & & $<31$ \\
\hline $22 / \mathrm{Mar} / 2010$ & 7.9 & -0.8 & 3.6 & 14.4 & 0 & 4 & 0 & 4 & 0 & 5 & 41 \\
\hline 23/Mar/2010 & 3.7 & 0.2 & 2 & 16 & 0 & 3.6 & 0 & 3.6 & 0 & 2 & 37 \\
\hline 24/Mar/2010 & 15.4 & -2 & 6.7 & 11.3 & 0 & 0 & 0 & 0 & 0 & 32 & 33 \\
\hline 25/Mar/2010 & 9 & -3.1 & 3 & 15 & 0 & 0 & 0 & 0 & 0 & & $<31$ \\
\hline $26 / \mathrm{Mar} / 2010$ & 0.9 & -6.7 & -2.9 & 20.9 & 0 & 0 & 0 & 0 & 0 & 2 & 46 \\
\hline $27 / \mathrm{Mar} / 2010$ & 4.6 & -6.6 & -1 & 19 & 0 & 0 & 0 & 0 & 0 & & $<31$ \\
\hline 28/Mar/2010 & 6.9 & 0.9 & 3.9 & 14.1 & 0 & 7.8 & 0 & 7.8 & 0 & & $<31$ \\
\hline 29/Mar/2010 & 8.8 & -0.5 & 4.2 & 13.8 & 0 & 1 & 0 & 1 & 0 & 3 & 39 \\
\hline $30 / \mathrm{Mar} / 2010$ & 12.6 & -2 & 5.3 & 12.7 & 0 & 0 & 0 & 0 & 0 & & $<31$ \\
\hline 31/Mar/2010 & 14.7 & 0.3 & 7.5 & 10.5 & 0 & 0 & 0 & 0 & 0 & & $<31$ \\
\hline $01 / \mathrm{Apr} / 2010$ & 19.3 & 6 & 12.7 & 5.3 & 0 & 0 & 0 & 0 & 0 & & $<31$ \\
\hline $02 / \mathrm{Apr} / 2010$ & 24.3 & 7.6 & 16 & 2 & 0 & 0 & 0 & 0 & 0 & & $<31$ \\
\hline $03 / \mathrm{Apr} / 2010$ & 21.9 & 7.2 & 14.6 & 3.4 & 0 & $T$ & 0 & $T$ & 0 & 25 & 72 \\
\hline $04 / \mathrm{Apr} / 2010$ & 18.1 & 5.8 & 12 & 6 & 0 & 0 & 0 & 0 & 0 & 17 & 44 \\
\hline
\end{tabular}




\begin{tabular}{|c|c|c|c|c|c|c|c|c|c|c|c|}
\hline 05/Apr/2010 & 23.1 & 9.9 & 16.5 & 1.5 & 0 & $\mathrm{~T}$ & 0 & $\mathrm{~T}$ & 0 & 28 & 59 \\
\hline 06/Apr/2010 & 13.3 & 8.7 & 11 & 7 & 0 & 7.2 & 0 & 7.2 & 0 & 11 & 32 \\
\hline 07/Apr/2010 & 17.2 & 8.4 & 12.8 & 5.2 & 0 & 14.4 & 0 & 14.4 & 0 & 24 & 32 \\
\hline $08 / \mathrm{Apr} / 2010$ & 11.6 & 3.7 & 7.7 & 10.3 & 0 & 10.8 & 0 & 10.8 & 0 & 26 & 46 \\
\hline 09/Apr/2010 & 4.1 & 1.3 & 2.7 & 15.3 & 0 & $\mathrm{~T}$ & $\mathrm{~T}$ & $\mathrm{~T}$ & 0 & 27 & 50 \\
\hline 10/Apr/2010 & 13.3 & -0.8 & 6.3 & 11.7 & 0 & $\mathrm{~T}$ & 0 & $\mathrm{~T}$ & 0 & 26 & 44 \\
\hline 11/Apr/2010 & 17.7 & 3.8 & 10.8 & 7.2 & 0 & 0 & 0 & 0 & 0 & 29 & 46 \\
\hline 12/Apr/2010 & 13.6 & 3.9 & 8.8 & 9.2 & 0 & 0 & 0 & 0 & 0 & 36 & 37 \\
\hline 13/Apr/2010 & 14.9 & 4.1 & 9.5 & 8.5 & 0 & 0 & 0 & 0 & 0 & & $<31$ \\
\hline 14/Apr/2010 & 16.5 & 2.2 & 9.4 & 8.6 & 0 & 0 & 0 & 0 & 0 & & $<31$ \\
\hline 15/Apr/2010 & 19.9 & 5.6 & 12.8 & 5.2 & 0 & 0 & 0 & 0 & 0 & & $<31$ \\
\hline 16/Apr/2010 & 21.6 & 4.6 & 13.1 & 4.9 & 0 & $\mathrm{~T}$ & 0 & $\mathrm{~T}$ & 0 & 31 & 63 \\
\hline 17/Apr/2010 & 7.9 & 3.2 & 5.6 & 12.4 & 0 & 0.2 & $\mathrm{~T}$ & 0.2 & 0 & 29 & 54 \\
\hline 18/Apr/2010 & 14 & 3.9 & 9 & 9 & 0 & $\mathrm{~T}$ & 0 & $\mathrm{~T}$ & 0 & 33 & 48 \\
\hline 19/Apr/2010 & 16.2 & 3.4 & 9.8 & 8.2 & 0 & 0 & 0 & 0 & 0 & 36 & 39 \\
\hline 20/Apr/2010 & 18.2 & 4.4 & 11.3 & 6.7 & 0 & 0 & 0 & 0 & 0 & & $<31$ \\
\hline 21/Apr/2010 & 19.1 & 3.4 & 11.3 & 6.7 & 0 & $\mathrm{~T}$ & 0 & $\mathrm{~T}$ & 0 & 34 & 48 \\
\hline 22/Apr/2010 & 12.6 & 1.7 & 7.2 & 10.8 & 0 & 0 & 0 & 0 & 0 & 32 & 33 \\
\hline 23/Apr/2010 & 15 & 0.9 & 8 & 10 & 0 & 0 & 0 & 0 & 0 & & $<31$ \\
\hline 24/Apr/2010 & 18.1 & 3 & 10.6 & 7.4 & 0 & 0 & 0 & 0 & 0 & & $<31$ \\
\hline 25/Apr/2010 & 12.7 & 9.3 & 11 & 7 & 0 & 3.6 & 0 & 3.6 & 0 & 8 & 41 \\
\hline 26/Apr/2010 & 17.5 & 5.3 & 11.4 & 6.6 & 0 & 0 & 0 & 0 & 0 & 36 & 57 \\
\hline 27/Apr/2010 & 10.6 & 2.8 & 6.7 & 11.3 & 0 & 0 & 0 & 0 & 0 & 33 & 54 \\
\hline 28/Apr/2010 & 14 & 4 & 9 & 9 & 0 & 0 & 0 & 0 & 0 & 33 & 54 \\
\hline 29/Apr/2010 & 19.5 & 3.5 & 11.5 & 6.5 & 0 & $\mathrm{~T}$ & 0 & $\mathrm{~T}$ & 0 & 23 & 32 \\
\hline 30/Apr/2010 & 20.9 & 10.6 & 15.8 & 2.2 & 0 & 0 & 0 & 0 & 0 & & $<31$ \\
\hline
\end{tabular}




\section{APPENDIX B}

Mobilization Data for

Winter Seasons 2004-2005 to 2009-2010 


\begin{tabular}{|c|c|c|c|c|c|}
\hline \multicolumn{6}{|c|}{$\begin{array}{c}\text { Mobilization Data for Winter 2004-2005 } \\
\text { City of Toronto - West District }\end{array}$} \\
\hline $\begin{array}{l}\text { Winter } \\
\text { Day No. }\end{array}$ & Date & $\begin{array}{l}\text { Mobilization } \\
\text { Per Date } \\
\text { Totals }\end{array}$ & $\begin{array}{c}\text { Units per } \\
\text { Day }\end{array}$ & $\begin{array}{c}\text { KM Driven } \\
\text { per Day }\end{array}$ & Operation \\
\hline 3 & 03-Nov-2004 & 1 & 1 & 22.8 & Salting \\
\hline 7 & 07-Nov-2004 & 2 & 2 & 258 & Anti-icing \\
\hline 8 & 08-Nov-2004 & 2 & 2 & 258 & Anti-icing \\
\hline 11 & 11-Nov-2004 & 2 & 2 & 258 & Anti-icing \\
\hline 13 & 13-Nov-2004 & 2 & 2 & 258 & Anti-icing \\
\hline 25 & 25-Nov-2004 & 17 & 17 & 436.2 & Salting \\
\hline 26 & 26-Nov-2004 & 61 & 40 & 1709.34 & Salting \\
\hline 28 & 28-Nov-2004 & 2 & 2 & 258 & Anti-icing \\
\hline 31 & 01-Dec-2004 & 2 & 2 & 258 & Anti-icing \\
\hline 33 & 03-Dec-2004 & 2 & 2 & 258 & Anti-icing \\
\hline 34 & 04-Dec-2004 & 2 & 2 & 258 & Anti-icing \\
\hline 36 & 06-Dec-2004 & 100 & 38 & 2729.2 & Salting \\
\hline 37 & 07-Dec-2004 & 79 & 38 & 2097.12 & Salting \\
\hline 41 & 11-Dec-2004 & 76 & 38 & 2030.19 & Salting \\
\hline 43 & 13-Dec-2004 & 2 & 2 & 271.9 & Anti-icing \\
\hline 45 & 15-Dec-2004 & 59 & 38 & 1593.99 & Salting \\
\hline 47 & 17-Dec-2004 & 65 & 38 & 1751.59 & Salting \\
\hline 49 & 19-Dec-2004 & 61 & 38 & 1645.99 & Salting \\
\hline 50 & 20-Dec-2004 & 35 & 26 & 894.98 & Salting \\
\hline 51 & 21-Dec-2004 & 83 & 38 & 2293 & Salting \\
\hline 52 & 22-Dec-2004 & 118 & 38 & 3187.98 & Salting \\
\hline 53 & 23-Dec-2004 & 159 & 38 & 4242.58 & Salting \\
\hline 54 & 24-Dec-2004 & 159 & 38 & 4241.33 & Salting \\
\hline 55 & 25-Dec-2004 & 83 & 38 & 2293 & Salting \\
\hline 56 & 26-Dec-2004 & 94 & 38 & 2571.6 & Salting \\
\hline 57 & 28-Dec-2004 & 59 & 38 & 1593.99 & Salting \\
\hline 62 & 01-Jan-2005 & 2 & 2 & 271.9 & Anti-icing \\
\hline 63 & 02-Jan-2005 & 61 & 38 & 1659.56 & Salting \\
\hline 64 & 04-Jan-2005 & 50 & 29 & 1576.99 & Salting \\
\hline 65 & 05-Jan-2005 & 33 & 20 & 870.12 & Salting \\
\hline 66 & 06-Jan-2005 & 173 & 38 & 5377.81 & Salting \\
\hline
\end{tabular}




\begin{tabular}{|c|c|c|c|c|c|}
\hline 67 & 07-Jan-2005 & 50 & 38 & 1594.67 & Salting \\
\hline 69 & 08-Jan-2005 & 59 & 38 & 1593.99 & Salting \\
\hline 71 & 10-Jan-2005 & 2 & 2 & 271.9 & Anti-icing \\
\hline 73 & 12-Jan-2005 & 67 & 38 & 2030.87 & Salting \\
\hline 74 & 13-Jan-2005 & 50 & 38 & 1594.67 & Salting \\
\hline 75 & 14-Jan-2005 & 44 & 32 & 1437.07 & Salting \\
\hline 76 & 15-Jan-2005 & 1 & 1 & 164.9 & Anti-icing \\
\hline 77 & 16-Jan-2005 & 50 & 38 & 1594.67 & Salting \\
\hline 78 & 17-Jan-2005 & 18 & 18 & 601.1 & Salting \\
\hline 80 & 19-Jan-2005 & 200 & 38 & 6378.68 & Salting \\
\hline 81 & 20-Jan-2005 & 40 & 27 & 1465.57 & Salting \\
\hline 82 & 21-Jan-2005 & 1 & 1 & 198.9 & Anti-icing \\
\hline 83 & 22-Jan-2005 & 170 & 38 & 5292.41 & Salting \\
\hline 84 & 23-Jan-2005 & 127 & 38 & 3970.95 & Salting \\
\hline 85 & 24-Jan-2005 & 100 & 38 & 3189.34 & Salting \\
\hline 86 & 25-Jan-2005 & 150 & 38 & 4784.41 & Salting \\
\hline 87 & 26-Jan-2005 & 67 & 38 & 2030.87 & Salting \\
\hline 88 & 27-Jan-2005 & 34 & 22 & 1323.37 & Salting \\
\hline 90 & 29-Jan-2005 & 1 & 1 & 27 & Salting \\
\hline 92 & 31-Jan-2005 & 2 & 2 & 271.9 & Anti-icing \\
\hline 95 & 03-Feb-2005 & 2 & 2 & 271.9 & Anti-icing \\
\hline 100 & 08-Feb-2005 & 19 & 19 & 708.1 & Salting \\
\hline 101 & 09-Feb-2005 & 150 & 38 & 4784.01 & Salting \\
\hline 102 & 10-Feb-2005 & 103 & 38 & 3258.54 & Salting \\
\hline 105 & 13-Feb-2005 & 2 & 2 & 271.9 & Anti-icing \\
\hline 106 & $14-F e b-2005$ & 50 & 38 & 1594.67 & Salting \\
\hline 108 & $16-F e b-2005$ & 100 & 38 & 3189.34 & Salting \\
\hline 109 & 17-Feb-2005 & 52 & 38 & 1644.67 & Salting \\
\hline 112 & 20-Feb-2005 & 100 & 38 & 3189.34 & Salting \\
\hline 113 & 21-Feb-2005 & 50 & 38 & 1594.47 & Salting \\
\hline 117 & 25-Feb-2005 & 100 & 38 & 3189.34 & Salting \\
\hline 118 & 26-Feb-2005 & 50 & 38 & 1594.67 & Salting \\
\hline 119 & 27-Feb-2005 & 2 & 2 & 340.5 & Anti-icing \\
\hline 120 & 28-Feb-2005 & 106 & 38 & 3346.94 & Salting \\
\hline 121 & 01-Mar-2005 & 117 & 38 & 3625.54 & Salting \\
\hline 122 & 02-Mar-2005 & 100 & 38 & 3189.34 & Salting \\
\hline 123 & 03-Mar-2005 & 33 & 21 & 1158.47 & Salting \\
\hline
\end{tabular}




\begin{tabular}{|c|c|c|c|c|c|}
\hline 127 & 07-Mar-2005 & 50 & 38 & 1594.67 & Salting \\
\hline 128 & $08-M a r-2005$ & 1 & 1 & 23.6 & Salting \\
\hline 129 & 09-Mar-2005 & 35 & 23 & 977.61 & Salting \\
\hline 130 & $10-$ Mar-2005 & 26 & 26 & 895.66 & Salting \\
\hline 131 & $11-$ Mar-2005 & 50 & 38 & 1594.67 & Salting \\
\hline 132 & $12-$ Mar-2005 & 59 & 38 & 2054.13 & Salting \\
\hline 133 & $13-$ Mar-2005 & 97 & 38 & 2887.48 & Salting \\
\hline 137 & $17-M a r-2005$ & 37 & 25 & 1474.17 & Salting \\
\hline 138 & $18-M a r-2005$ & 2 & 2 & 271.9 & Anti-icing \\
\hline 139 & $19-M a r-2005$ & 1 & 1 & 25.4 & Salting \\
\hline 141 & 21-Mar-2005 & 52 & 40 & 1866.57 & Salting \\
\hline 143 & 23-Mar-2005 & 50 & 38 & 1594.67 & Salting \\
\hline 144 & 24-Mar-2005 & 52 & 40 & 1866.57 & Salting \\
\hline 152 & 01-Apr-2005 & 2 & 2 & 271.9 & Anti-icing \\
\hline 154 & 03-Apr-2005 & 12 & 12 & 300.8 & Salting \\
\hline
\end{tabular}

\begin{tabular}{|c|c|c|c|c|c|}
\hline \multicolumn{6}{|c|}{$\begin{array}{c}\text { Mobilization Data for Winter 2005-2006 } \\
\text { City of Toronto - West District }\end{array}$} \\
\hline $\begin{array}{l}\text { Winter } \\
\text { Day No. }\end{array}$ & Date & $\begin{array}{l}\text { Mobilization } \\
\text { Per Date } \\
\text { Totals }\end{array}$ & $\begin{array}{l}\text { Units per } \\
\text { Day }\end{array}$ & $\begin{array}{l}\text { KM Driven } \\
\text { per Day }\end{array}$ & Operation \\
\hline 10 & 10-Nov-2005 & 2 & 1 & 279.42 & Anti-icing \\
\hline 16 & 16-Nov-2005 & 2 & 2 & 279.42 & Anti-icing \\
\hline 17 & 17-Nov-2005 & 2 & 2 & 279.42 & Anti-icing \\
\hline 18 & 18-Nov-2005 & 112 & 38 & 2357.19 & Salting \\
\hline 22 & 22-Nov-2005 & 2 & 2 & 279.42 & Anti-icing \\
\hline 23 & 23-Nov-2005 & 106 & 38 & 2199.68 & Salting \\
\hline 24 & 24-Nov-2005 & 354 & 38 & 7616.78 & Salting \\
\hline 25 & 25-Nov-2005 & 244 & 38 & 4627.76 & Salting \\
\hline 26 & 26-Nov-2005 & 95 & 38 & 1920.99 & Salting \\
\hline 30 & $30-N o v-2005$ & 1 & 1 & 164.9 & Anti-icing \\
\hline 32 & 02-Dec-2005 & 148 & 38 & 3365 & Salting \\
\hline 33 & 03-Dec-2005 & 31 & 16 & 796.73 & Salting \\
\hline 34 & 04-Dec-2005 & 117 & 38 & 2496.02 & Salting \\
\hline 39 & 09-Dec-2005 & 202 & 38 & 4138.98 & Salting \\
\hline 43 & 13-Dec-2005 & 17 & 17 & 436.2 & Salting \\
\hline 44 & 14-Dec-2005 & 128 & 37 & 3096.03 & Salting \\
\hline 45 & 15-Dec-2005 & 215 & 38 & 5353.77 & Salting \\
\hline
\end{tabular}




\begin{tabular}{|c|c|c|c|c|c|}
\hline 46 & 16-Dec-2005 & 77 & 38 & 1920.99 & Salting \\
\hline 47 & 17-Dec-2005 & 3 & 2 & 227.46 & Anti-icing \\
\hline 50 & 20-Dec-2005 & 77 & 38 & 1920.99 & Salting \\
\hline 55 & 25-Dec-2005 & 77 & 38 & 1920.99 & Salting \\
\hline 56 & 26-Dec-2005 & 26 & 12 & 764.58 & Salting \\
\hline 57 & 27-Dec-2005 & 2 & 2 & 279.42 & Anti-icing \\
\hline 59 & 29-Dec-2005 & 2 & 2 & 279.42 & Anti-icing \\
\hline 60 & 30-Dec-2005 & 4 & 2 & 279.42 & Anti-icing \\
\hline 61 & 31-Dec-2005 & 351 & 39 & 8856.66 & Salting \\
\hline 62 & 01-Jan-2006 & 2 & 1 & 54.38 & Salting \\
\hline 66 & 05-Jan-2006 & 2 & 2 & 279.42 & Anti-icing \\
\hline 68 & 07-Jan-2006 & 120 & 40 & 3859.98 & Salting \\
\hline 69 & 08-Jan-2006 & 1 & 1 & 25.4 & Salting \\
\hline 70 & 09-Jan-2006 & 2 & 2 & 279.42 & Anti-icing \\
\hline 75 & 14-Jan-2006 & 61 & 40 & 2025.08 & Salting \\
\hline 76 & 15-Jan-2006 & 24 & 15 & 1039.12 & Salting \\
\hline 77 & 16-Jan-2006 & 1 & 1 & 2 & Salting \\
\hline 78 & 17-Jan-2006 & 72 & 40 & 2219.59 & Salting \\
\hline 79 & 18-Jan-2006 & 85 & 40 & 2635 & Salting \\
\hline 80 & 19-Jan-2006 & 1 & 1 & 24.6 & Salting \\
\hline 82 & 21-Jan-2006 & 66 & 42 & 2284.16 & Salting \\
\hline 84 & 23-Jan-2006 & 2 & 2 & 279.42 & Anti-icing \\
\hline 86 & 25-Jan-2006 & 67 & 40 & 2088.71 & Salting \\
\hline 91 & 30-Jan-2006 & 2 & 2 & 279.42 & Anti-icing \\
\hline 92 & 31-Jan-2006 & 2 & 2 & 279.42 & Anti-icing \\
\hline 97 & 05-Feb-2006 & 120 & 40 & 3855.65 & Salting \\
\hline 98 & 06-Feb-2006 & 155 & 40 & 4831.59 & Salting \\
\hline 99 & 07-Feb-2006 & 37 & 23 & 1021.41 & Salting \\
\hline 102 & 10-Feb-2006 & 120 & 40 & 3867.81 & Salting \\
\hline 107 & $15-$ Feb-2006 & 2 & 2 & 279.42 & Anti-icing \\
\hline 108 & 16-Feb-2006 & 256 & 40 & 8506.83 & Salting \\
\hline 109 & 17-Feb-2006 & 61 & 40 & 1932.82 & Salting \\
\hline 110 & 18-Feb-2006 & 96 & 40 & 2909.43 & Salting \\
\hline 116 & 24-Feb-2006 & 2 & 2 & 279.42 & Anti-icing \\
\hline 117 & 25-Feb-2006 & 213 & 40 & 6414.84 & Salting \\
\hline 118 & 26-Feb-2006 & 58 & 35 & 1885.36 & Salting \\
\hline 130 & 10-Mar-2006 & 2 & 2 & 279.42 & Anti-icing \\
\hline
\end{tabular}




\begin{tabular}{|l|l|l|l|l|l|}
\hline 134 & $14-M a r-2006$ & 2 & 2 & 279.42 & Anti-icing \\
\hline 137 & $17-M a r-2006$ & 2 & 2 & 279.42 & Anti-icing \\
\hline 140 & $20-M a r-2006$ & 2 & 2 & 279.42 & Anti-icing \\
\hline 142 & $22-M a r-2006$ & 2 & 2 & 279.42 & Anti-icing \\
\hline 146 & $26-M a r-2006$ & 2 & 2 & 279.42 & Anti-icing \\
\hline 152 & 01-Apr-2006 & 2 & 2 & 279.42 & Anti-icing \\
\hline 155 & 04-Apr-2006 & 2 & 2 & 279.42 & Anti-icing \\
\hline 156 & 05-Apr-2006 & 10 & 10 & 606.22 & Salting \\
\hline
\end{tabular}

\begin{tabular}{|c|c|c|c|c|c|}
\hline \multicolumn{6}{|c|}{$\begin{array}{c}\text { Mobilization Data for Winter 2006-2007 } \\
\text { City of Toronto - West District }\end{array}$} \\
\hline $\begin{array}{l}\text { Winter } \\
\text { Day No. }\end{array}$ & Date & $\begin{array}{l}\text { Mobilization } \\
\text { Per Date } \\
\text { Totals }\end{array}$ & $\begin{array}{l}\text { Units per } \\
\text { Day }\end{array}$ & $\begin{array}{l}\text { KM Driven } \\
\text { per Day }\end{array}$ & Operation \\
\hline 1 & 01-Nov-2006 & 6 & 4 & 279.42 & Anti-icing \\
\hline 3 & 03-Nov-2006 & 6 & 4 & 279.42 & Anti-icing \\
\hline 18 & 18-Nov-2006 & 6 & 4 & 279.42 & Anti-icing \\
\hline 22 & 22-Nov-2006 & 6 & 4 & 279.42 & Anti-icing \\
\hline 32 & 02-Dec-2006 & 37 & 25 & 1257.03 & Salting \\
\hline 33 & 03-Dec-2006 & 7 & 6 & 224.64 & Salting \\
\hline 34 & 04-Dec-2006 & 72 & 39 & 2240.24 & Salting \\
\hline 35 & 05-Dec-2006 & 35 & 23 & 977.61 & Salting \\
\hline 37 & 07-Dec-2006 & 35 & 23 & 977.61 & Salting \\
\hline 45 & 15-Dec-2006 & 2 & 2 & 279.42 & Anti-icing \\
\hline 49 & 19-Dec-2006 & 2 & 2 & 279.42 & Anti-icing \\
\hline 57 & 27-Dec-2006 & 72 & 38 & 2261.45 & Salting \\
\hline 59 & 29-Dec-2006 & 35 & 23 & 977.61 & Salting \\
\hline 60 & 30-Dec-2006 & 59 & 38 & 1920.99 & Salting \\
\hline 63 & 02-Jan-2007 & 2 & 2 & 279.42 & Anti-icing \\
\hline 67 & 06-Jan-2007 & 2 & 1 & 279.42 & Anti-icing \\
\hline 69 & 08-Jan-2007 & 1 & 1 & 164.9 & Anti-icing \\
\hline 70 & 09-Jan-2007 & 1 & 1 & 114.52 & Anti-icing \\
\hline 71 & 10-Jan-2007 & 35 & 23 & 977.61 & Salting \\
\hline 74 & 13-Jan-2007 & 59 & 38 & 1920.99 & Salting \\
\hline 75 & 14-Jan-2007 & 61 & 40 & 1925.24 & Salting \\
\hline 76 & 15-Jan-2007 & 284 & 40 & 9107.65 & Salting \\
\hline 77 & 16-Jan-2007 & 104 & 40 & 3460.68 & Salting \\
\hline 78 & 17-Jan-2007 & 44 & 23 & 1496.92 & Salting \\
\hline
\end{tabular}




\begin{tabular}{|c|c|c|c|c|c|}
\hline 80 & 19-Jan-2007 & 55 & 34 & 1775.42 & Salting \\
\hline 83 & 22-Jan-2007 & 133 & 40 & 4143.03 & Salting \\
\hline 84 & 23-Jan-2007 & 20 & 5 & 536.78 & Salting \\
\hline 85 & 24-Jan-2007 & 26 & 15 & 998.18 & Salting \\
\hline 87 & 26-Jan-2007 & 180 & 40 & 5800.79 & Salting \\
\hline 88 & 27-Jan-2007 & 121 & 40 & 3890.28 & Salting \\
\hline 89 & 28-Jan-2007 & 120 & 40 & 3863.23 & Salting \\
\hline 91 & 30-Jan-2007 & 120 & 40 & 3864.65 & Salting \\
\hline 95 & 03-Feb-2007 & 3 & 3 & 80.2 & Salting \\
\hline 96 & 04-Feb-2007 & 3 & 2 & 87.96 & Salting \\
\hline 97 & 05-Feb-2007 & 218 & 40 & 7121.39 & Salting \\
\hline 98 & 06-Feb-2007 & 61 & 40 & 1931.83 & Salting \\
\hline 105 & 13-Feb-2007 & 120 & 40 & 3853.23 & Salting \\
\hline 106 & 14-Feb-2007 & 148 & 38 & 4872.58 & Salting \\
\hline 107 & 15-Feb-2007 & 61 & 40 & 1932.49 & Salting \\
\hline 108 & 16-Feb-2007 & 97 & 40 & 2936.85 & Salting \\
\hline 113 & 21-Feb-2007 & 2 & 2 & 279.42 & Anti-icing \\
\hline 114 & 22-Feb-2007 & 120 & 40 & 3847.73 & Salting \\
\hline 117 & 25-Feb-2007 & 127 & 40 & 4028.23 & Salting \\
\hline 118 & 26-Feb-2007 & 214 & 40 & 7015.45 & Salting \\
\hline 119 & 27-Feb-2007 & 60 & 38 & 1946.39 & Salting \\
\hline 121 & 01-Mar-2007 & 144 & 40 & 4464.53 & Salting \\
\hline 122 & 02-Mar-2007 & 180 & 40 & 5817.75 & Salting \\
\hline 125 & 05-Mar-2007 & 95 & 38 & 2924 & Salting \\
\hline 127 & 07-Mar-2007 & 120 & 40 & 3854.48 & Salting \\
\hline 130 & 10-Mar-2007 & 2 & 2 & 279.42 & Anti-icing \\
\hline 131 & 11-Mar-2007 & 1 & 1 & 24.6 & Salting \\
\hline 132 & 12-Mar-2007 & 2 & 2 & 55.6 & Salting \\
\hline 135 & 15-Mar-2007 & 2 & 2 & 279.42 & Anti-icing \\
\hline 136 & 16-Mar-2007 & 121 & 41 & 3866.13 & Salting \\
\hline 137 & 17-Mar-2007 & 122 & 40 & 3885.48 & Salting \\
\hline 142 & 22-Mar-2007 & 2 & 2 & 279.42 & Anti-icing \\
\hline 144 & 24-Mar-2007 & 2 & 2 & 279.42 & Anti-icing \\
\hline 156 & 05-Apr-2007 & 76 & 38 & 2357.19 & Salting \\
\hline
\end{tabular}




\begin{tabular}{|c|c|c|c|c|c|}
\hline \multicolumn{6}{|c|}{$\begin{array}{c}\text { Mobilization Data for Winter 2007-2008 } \\
\text { City of Toronto - West District }\end{array}$} \\
\hline $\begin{array}{l}\text { Winter } \\
\text { Day No. }\end{array}$ & Date & $\begin{array}{l}\text { Mobilization } \\
\text { Per Date } \\
\text { Totals }\end{array}$ & $\begin{array}{l}\text { Units per } \\
\text { Day }\end{array}$ & $\begin{array}{c}\text { KM Driven } \\
\text { per Day }\end{array}$ & Operation \\
\hline 1 & 01-Nov-2007 & 2 & 1 & 279.42 & Anti-icing \\
\hline 7 & 07-Nov-2007 & 2 & 2 & 279.42 & Anti-icing \\
\hline 10 & 10-Nov-2007 & 2 & 2 & 279.42 & Anti-icing \\
\hline 22 & 22-Nov-2007 & 246 & 40 & 7851.45 & Salting \\
\hline 23 & 23-Nov-2007 & 57 & 35 & 1840.99 & Salting \\
\hline 27 & 27-Nov-2007 & 37 & 24 & 1122.33 & Salting \\
\hline 28 & 28-Nov-2007 & 9 & 6 & 276.11 & Salting \\
\hline 29 & 29-Nov-2007 & 2 & 2 & 279.42 & Anti-icing \\
\hline 30 & $30-N o v-2007$ & 43 & 31 & 1141.71 & Salting \\
\hline 32 & 02-Dec-2007 & 165 & 40 & 5006.81 & Salting \\
\hline 33 & 03-Dec-2007 & 61 & 40 & 1921.82 & Salting \\
\hline 34 & 04-Dec-2007 & 36 & 24 & 1015.44 & Salting \\
\hline 38 & 08-Dec-2007 & 1 & 1 & 2 & Salting \\
\hline 39 & 09-Dec-2007 & 42 & 30 & 1176.14 & Salting \\
\hline 40 & 10-Dec-2007 & 62 & 41 & 1974.09 & Salting \\
\hline 41 & 11-Dec-2007 & 111 & 41 & 3666.48 & Salting \\
\hline 42 & 12-Dec-2007 & 1 & 1 & 164.9 & Anti-icing \\
\hline 43 & 13-Dec-2007 & 116 & 41 & 3779.07 & Salting \\
\hline 45 & 15-Dec-2007 & 183 & 41 & 5600.46 & Salting \\
\hline 47 & 17-Dec-2007 & 140 & 41 & 4721.12 & Salting \\
\hline 48 & 18-Dec-2007 & 62 & 41 & 1976.75 & Salting \\
\hline 57 & 20-Dec-2007 & 2 & 2 & 279.42 & Anti-icing \\
\hline 58 & 24-Dec-2007 & 94 & 38 & 2898.6 & Salting \\
\hline 59 & 27-Dec-2007 & 61 & 40 & 1930.9 & Salting \\
\hline 60 & 29-Dec-2007 & 2 & 2 & 279.42 & Salting \\
\hline 61 & 31-Dec-2007 & 96 & 40 & 2912.1 & Salting \\
\hline 62 & 01-Jan-2008 & 237 & 40 & 7691.04 & Salting \\
\hline 63 & 02-Jan-2008 & 24 & 12 & 699.01 & Salting \\
\hline 71 & 10-Jan-2008 & 2 & 2 & 279.42 & Anti-icing \\
\hline 72 & 11-Jan-2008 & 2 & 2 & 279.42 & Anti-icing \\
\hline 76 & 15-Jan-2008 & 97 & 40 & 2939.18 & Salting \\
\hline 79 & 18-Jan-2008 & 61 & 40 & 1929.24 & Salting \\
\hline 80 & 19-Jan-2008 & 12 & 9 & 410.22 & Salting \\
\hline
\end{tabular}




\begin{tabular}{|c|c|c|c|c|c|}
\hline 81 & 20-Jan-2008 & 1 & 1 & 2 & Salting \\
\hline 83 & 22-Jan-2008 & 180 & 41 & 5815.57 & Salting \\
\hline 84 & 23-Jan-2008 & 44 & 23 & 1495.12 & Salting \\
\hline 85 & 24-Jan-2008 & 72 & 40 & 2210 & Salting \\
\hline 87 & 26-Jan-2008 & 120 & 40 & 3854.9 & Salting \\
\hline 88 & 27-Jan-2008 & 35 & 26 & 1221.98 & Salting \\
\hline 90 & 29-Jan-2008 & 61 & 40 & 1932.99 & Salting \\
\hline 91 & 30-Jan-2008 & 62 & 41 & 1971.52 & Salting \\
\hline 92 & 31-Jan-2008 & 35 & 23 & 977.61 & Salting \\
\hline 93 & 01-Feb-2008 & 176 & 40 & 5284.35 & Salting \\
\hline 94 & 02-Feb-2008 & 61 & 40 & 1931.99 & Salting \\
\hline 95 & 03-Feb-2008 & 35 & 23 & 977.61 & Salting \\
\hline 96 & 04-Feb-2008 & 59 & 38 & 1920.99 & Salting \\
\hline 98 & 06-Feb-2008 & 295 & 41 & 9637.5 & Salting \\
\hline 99 & 07-Feb-2008 & 169 & 41 & 5231.98 & Salting \\
\hline 100 & 08-Feb-2008 & 26 & 17 & 951.55 & Salting \\
\hline 101 & 09-Feb-2008 & 193 & 41 & 6192.59 & Salting \\
\hline 103 & 11-Feb-2008 & 35 & 23 & 977.61 & Salting \\
\hline 104 & 12-Feb-2008 & 182 & 41 & 5900.01 & Salting \\
\hline 105 & 13-Feb-2008 & 155 & 40 & 4832.17 & Salting \\
\hline 109 & 17-Feb-2008 & 120 & 40 & 3852.4 & Salting \\
\hline 110 & 18-Feb-2008 & 61 & 40 & 1935.74 & Salting \\
\hline 111 & 19-Feb-2008 & 105 & 23 & 2932.83 & Salting \\
\hline 114 & 22-Feb-2008 & 59 & 38 & 1920.99 & Salting \\
\hline 116 & 24-Feb-2008 & 11 & 11 & 278.6 & Salting \\
\hline 118 & 26-Feb-2008 & 120 & 40 & 3852.32 & Salting \\
\hline 119 & 27-Feb-2008 & 61 & 40 & 1930.74 & Salting \\
\hline 121 & 29-Feb-2008 & 141 & 41 & 4419.81 & Salting \\
\hline 122 & 01-Mar-2008 & 62 & 41 & 1977.67 & Salting \\
\hline 124 & 03-Mar-2008 & 62 & 41 & 1971.92 & Salting \\
\hline 125 & 04-Mar-2008 & 162 & 41 & 5107.3 & Salting \\
\hline 126 & 05-Mar-2008 & 46 & 24 & 1536.51 & Salting \\
\hline 128 & 07-Mar-2008 & 163 & 42 & 5272.69 & Salting \\
\hline 129 & 08-Mar-2008 & 119 & 38 & 3860.38 & Salting \\
\hline 130 & 09-Mar-2008 & 126 & 40 & 4286.38 & Salting \\
\hline 131 & 10-Mar-2008 & 20 & 11 & 803.78 & Salting \\
\hline 133 & 12-Mar-2008 & 62 & 41 & 1970.81 & Salting \\
\hline
\end{tabular}




\begin{tabular}{|c|c|c|c|c|c|}
\hline 134 & 13-Mar-2008 & 11 & 11 & 278.6 & Salting \\
\hline 137 & 16-Mar-2008 & 39 & 27 & 1345.51 & Salting \\
\hline 138 & 17-Mar-2008 & 39 & 23 & 1077.21 & Salting \\
\hline 140 & 19-Mar-2008 & 2 & 2 & 279.42 & Anti-icing \\
\hline 141 & $20-$ Mar-2008 & 17 & 11 & 441 & Salting \\
\hline 142 & $21-$ Mar-2008 & 18 & 12 & 488.2 & Salting \\
\hline 143 & $22-$ Mar-2008 & 1 & 1 & 2 & Salting \\
\hline 144 & 23-Mar-2008 & 17 & 12 & 474.08 & Salting \\
\hline 145 & 24-Mar-2008 & 123 & 41 & 3964.01 & Salting \\
\hline 147 & 26-Mar-2008 & 36 & 24 & 1018.54 & Salting \\
\hline
\end{tabular}

\begin{tabular}{|c|c|c|c|c|c|}
\hline \multicolumn{6}{|c|}{$\begin{array}{c}\text { Mobilization Data for Winter 2008-2009 } \\
\text { City of Toronto - West District }\end{array}$} \\
\hline $\begin{array}{l}\text { Winter } \\
\text { Day No. }\end{array}$ & Date & $\begin{array}{l}\text { Mobilization } \\
\text { Per Date } \\
\text { Totals }\end{array}$ & $\begin{array}{l}\text { Units per } \\
\text { Day }\end{array}$ & $\begin{array}{l}\text { KM Driven } \\
\text { per Day }\end{array}$ & Operation \\
\hline 10 & 10-Nov-2008 & 3 & 2 & 221.42 & Anti-icing \\
\hline 16 & 16-Nov-2008 & 4 & 4 & 214.1 & Anti-icing \\
\hline 17 & 17-Nov-2008 & 2 & 2 & 106.9 & Anti-icing \\
\hline 19 & 19-Nov-2008 & 40 & 40 & 2592.16 & Salting \\
\hline 20 & 20-Nov-2008 & 40 & 40 & 1725.03 & Salting \\
\hline 28 & 28-Nov-2008 & 4 & 4 & 214.1 & Anti-icing \\
\hline 32 & 02-Dec-2008 & 19 & 19 & 654.86 & Salting \\
\hline 34 & 04-Dec-2008 & 4 & 4 & 214.1 & Anti-icing \\
\hline 36 & 06-Dec-2008 & 40 & 40 & 2000.47 & Salting \\
\hline 37 & 07-Dec-2008 & 40 & 40 & 1386.38 & Salting \\
\hline 38 & 08-Dec-2008 & 40 & 40 & 1614.95 & Salting \\
\hline 39 & 09-Dec-2008 & 42 & 42 & 4420.75 & Salting \\
\hline 40 & 10-Dec-2008 & 42 & 42 & 2530.96 & Salting \\
\hline 42 & 12-Dec-2008 & 3 & 3 & 181 & Salting \\
\hline 44 & 14-Dec-2008 & 21 & 21 & 633.34 & Salting \\
\hline 45 & 15-Dec-2008 & 4 & 4 & 214.1 & Anti-icing \\
\hline 46 & 16-Dec-2008 & 21 & 21 & 1525.49 & Salting \\
\hline 47 & 17-Dec-2008 & 21 & 21 & 1747.83 & Salting \\
\hline 48 & 18-Dec-2008 & 1 & 1 & 26.67 & Salting \\
\hline 49 & 19-Dec-2008 & 42 & 42 & 3284.08 & Salting \\
\hline 50 & 20-Dec-2008 & 42 & 42 & 2894.32 & Salting \\
\hline 51 & 21-Dec-2008 & 39 & 39 & 2787.25 & Salting \\
\hline
\end{tabular}




\begin{tabular}{|c|c|c|c|c|c|}
\hline 52 & 22-Dec-2008 & 42 & 42 & 2904.68 & Salting \\
\hline 53 & 23-Dec-2008 & 42 & 42 & 2693.35 & Salting \\
\hline 55 & 25-Dec-2008 & 42 & 42 & 1475.54 & Salting \\
\hline 56 & $26-\mathrm{Dec}-2008$ & 42 & 42 & 1465.74 & Salting \\
\hline 59 & 29-Dec-2008 & 4 & 4 & 214.1 & Anti-icing \\
\hline 60 & 30-Dec-2008 & 21 & 21 & 1284.17 & Salting \\
\hline 61 & 31-Dec-2008 & 40 & 40 & 2604.33 & Salting \\
\hline 63 & 02-Jan-2009 & 42 & 42 & 1465.74 & Salting \\
\hline 65 & 04-Jan-2009 & 21 & 21 & 855.59 & Salting \\
\hline 67 & 06-Jan-2009 & 21 & 21 & 1284.17 & Salting \\
\hline 68 & 07-Jan-2009 & 42 & 42 & 3333.42 & Salting \\
\hline 69 & 08-Jan-2009 & 42 & 42 & 1465.74 & Salting \\
\hline 71 & 10-Jan-2009 & 42 & 42 & 2600.81 & Salting \\
\hline 72 & 11-Jan-2009 & 32 & 32 & 1409.57 & Salting \\
\hline 73 & 12-Jan-2009 & 32 & 32 & 1009.3 & Salting \\
\hline 74 & 13-Jan-2009 & 42 & 42 & 2693.35 & Salting \\
\hline 75 & 14-Jan-2009 & 39 & 39 & 1284.14 & Salting \\
\hline 76 & 15-Jan-2009 & 39 & 39 & 1623.39 & Salting \\
\hline 78 & 17-Jan-2009 & 42 & 42 & 2693.35 & Salting \\
\hline 79 & 18-Jan-2009 & 42 & 42 & 1804.39 & Salting \\
\hline 80 & 19-Jan-2009 & 39 & 39 & 2569.28 & Salting \\
\hline 84 & 23-Jan-2009 & 6 & 6 & 206.59 & Salting \\
\hline 85 & 24-Jan-2009 & 6 & 6 & 206.59 & Salting \\
\hline 89 & 28-Jan-2009 & 42 & 42 & 3363.61 & Salting \\
\hline 90 & 29-Jan-2009 & 42 & 42 & 2750.48 & Salting \\
\hline 91 & 30-Jan-2009 & 39 & 39 & 1284.74 & Salting \\
\hline 92 & 31-Jan-2009 & 42 & 42 & 1465.75 & Salting \\
\hline 95 & 03-Feb-2009 & 31 & 31 & 2063.78 & Salting \\
\hline 96 & 04-Feb-2009 & 39 & 39 & 1284.74 & Salting \\
\hline 97 & 05-Feb-2009 & 3 & 3 & 181 & Salting \\
\hline 100 & 08-Feb-2009 & 39 & 39 & 1371.94 & Salting \\
\hline 101 & 09-Feb-2009 & 2 & 2 & 106.9 & Anti-icing \\
\hline 108 & 16-Feb-2009 & 11 & 11 & 629.57 & Salting \\
\hline 109 & 17-Feb-2009 & 5 & 5 & 241.48 & Salting \\
\hline 110 & 18-Feb-2009 & 42 & 42 & 2309.34 & Salting \\
\hline 111 & 19-Feb-2009 & 39 & 39 & 2569.48 & Salting \\
\hline 112 & 20-Feb-2009 & 42 & 42 & 1465.74 & Salting \\
\hline
\end{tabular}




\begin{tabular}{|c|c|c|c|c|c|}
\hline 113 & $21-$ Feb-2009 & 39 & 39 & 2236.91 & Salting \\
\hline 114 & $22-$ Feb-2009 & 33 & 33 & 1175.21 & Salting \\
\hline 115 & $23-$ Feb-2009 & 22 & 22 & 748.03 & Salting \\
\hline 116 & $24-$ Feb-2009 & 3 & 3 & 181 & Salting \\
\hline 117 & $25-$ Feb-2009 & 21 & 21 & 670.65 & Salting \\
\hline 118 & $26-$ Feb-2009 & 18 & 18 & 614.09 & Salting \\
\hline 126 & $06-$ Mar-2009 & 4 & 4 & 214.1 & Anti-icing \\
\hline 129 & $09-M a r-2009$ & 46 & 46 & 1679.84 & Salting \\
\hline 132 & $12-M a r-2009$ & 35 & 35 & 1559.35 & Salting \\
\hline 146 & $26-M a r-2009$ & 4 & 4 & 214.1 & Anti-icing \\
\hline 157 & 06-Apr-2009 & 30 & 30 & 994.11 & Salting \\
\hline 158 & $07-A p r-2009$ & 32 & 32 & 1030.65 & Salting \\
\hline 161 & $10-A p r-2009$ & 2 & 2 & 107.2 & Anti-icing \\
\hline 162 & $11-A p r-2009$ & 2 & 2 & 107.2 & Anti-icing \\
\hline 163 & $12-A p r-2009$ & 2 & 2 & 107.2 & Anti-icing \\
\hline
\end{tabular}

\section{Mobilization Data for Winter 2009-2010}

\begin{tabular}{|c|c|c|c|c|c|}
\hline \multicolumn{6}{|c|}{ City of Toronto - West District } \\
\hline $\begin{array}{l}\text { Winter } \\
\text { Day No. }\end{array}$ & Date & $\begin{array}{c}\text { Mobilization } \\
\text { Per Date } \\
\text { Totals }\end{array}$ & $\begin{array}{c}\text { Units per } \\
\text { Day }\end{array}$ & $\begin{array}{l}\text { KM Driven } \\
\text { per Day }\end{array}$ & Operation \\
\hline 3 & 03-Nov-2009 & 4 & 3 & 214.1 & Anti-icing \\
\hline 5 & 05-Nov-2009 & 4 & 4 & 214.1 & Anti-icing \\
\hline 10 & 10-Nov-2009 & 4 & 4 & 214.1 & Anti-icing \\
\hline 12 & 12-Nov-2009 & 4 & 4 & 213.48 & Anti-icing \\
\hline 16 & 16-Nov-2009 & 4 & 4 & 214.1 & Anti-icing \\
\hline 27 & 27-Nov-2009 & 4 & 4 & 214.1 & Anti-icing \\
\hline 30 & 30-Nov-2009 & 4 & 4 & 214.1 & Anti-icing \\
\hline 33 & 03-Dec-2009 & 4 & 4 & 214.1 & Anti-icing \\
\hline 36 & 06-Dec-2009 & 4 & 4 & 214.1 & Anti-icing \\
\hline 38 & 08-Dec-2009 & 1 & 1 & 40.84 & Salting \\
\hline 39 & 09-Dec-2009 & 42 & 42 & 3489.37 & Salting \\
\hline 40 & 10-Dec-2009 & 42 & 42 & 2154.76 & Salting \\
\hline 44 & 14-Dec-2009 & 1 & 1 & 40.84 & Salting \\
\hline 45 & 15-Dec-2009 & 42 & 42 & 2136.39 & Salting \\
\hline 53 & 23-Dec-2009 & 20 & 20 & 721.29 & Salting \\
\hline 54 & 24-Dec-2009 & 39 & 39 & 1284.74 & Salting \\
\hline 56 & 26-Dec-2009 & 25 & 25 & 884.75 & Salting \\
\hline
\end{tabular}




\begin{tabular}{|c|c|c|c|c|c|}
\hline 57 & 27-Dec-2009 & 42 & 42 & 1465.76 & Salting \\
\hline 58 & 28-Dec-2009 & 42 & 42 & 1465.74 & Salting \\
\hline 59 & 29-Dec-2009 & 4 & 4 & 134.36 & Salting \\
\hline 61 & 31-Dec-2009 & 4 & 4 & 214.1 & Anti-icing \\
\hline 62 & 01-Jan-2010 & 42 & 42 & 2931.48 & Salting \\
\hline 64 & 03-Jan-2010 & 42 & 42 & 4316.74 & Salting \\
\hline 65 & 04-Jan-2010 & 42 & 42 & 2079.83 & Salting \\
\hline 66 & 05-Jan-2010 & 42 & 42 & 3379.27 & Salting \\
\hline 67 & 06-Jan-2010 & 42 & 42 & 1465.74 & Salting \\
\hline 69 & 08-Jan-2010 & 42 & 42 & 2402.82 & Salting \\
\hline 72 & 11-Jan-2010 & 39 & 39 & 1898.83 & Salting \\
\hline 73 & 12-Jan-2010 & 4 & 4 & 207.6 & Salting \\
\hline 76 & 15-Jan-2010 & 4 & 4 & 214.1 & Anti-icing \\
\hline 79 & 18-Jan-2010 & 4 & 4 & 214.1 & Anti-icing \\
\hline 80 & 19-Jan-2010 & 18 & 18 & 614.09 & Salting \\
\hline 81 & 20-Jan-2010 & 3 & 3 & 181 & Salting \\
\hline 82 & 21-Jan-2010 & 4 & 4 & 214.1 & Anti-icing \\
\hline 86 & 25-Jan-2010 & 4 & 4 & 214.1 & Anti-icing \\
\hline 88 & 27-Jan-2010 & 39 & 39 & 1311.34 & Salting \\
\hline 89 & 28-Jan-2010 & 33 & 33 & 1174.61 & Salting \\
\hline 94 & 02-Feb-2010 & 39 & 39 & 1623.39 & Salting \\
\hline 95 & 03-Feb-2010 & 42 & 42 & 1465.74 & Salting \\
\hline 101 & 09-Feb-2010 & 39 & 39 & 1735.41 & Salting \\
\hline 102 & 10-Feb-2010 & 42 & 42 & 3388.12 & Salting \\
\hline 103 & 11-Feb-2010 & 3 & 3 & 181 & Salting \\
\hline 105 & 13-Feb-2010 & 18 & 18 & 614.09 & Salting \\
\hline 108 & 16-Feb-2010 & 39 & 39 & 1284.74 & Salting \\
\hline 109 & 17-Feb-2010 & 21 & 21 & 795.09 & Salting \\
\hline 114 & 22-Feb-2010 & 42 & 42 & 2693.35 & Salting \\
\hline 115 & 23-Feb-2010 & 42 & 42 & 2136.39 & Salting \\
\hline 116 & 24-Feb-2010 & 21 & 21 & 795.09 & Salting \\
\hline 117 & 25-Feb-2010 & 42 & 42 & 4159.09 & Salting \\
\hline 118 & 26-Feb-2010 & 42 & 42 & 3068.44 & Salting \\
\hline 119 & 27-Feb-2010 & 1 & 1 & 36.04 & Salting \\
\hline 120 & 28-Feb-2010 & 42 & 42 & 2079.83 & Salting \\
\hline 128 & 08-Mar-2010 & 4 & 4 & 214.1 & Anti-icing \\
\hline 141 & 21-Mar-2010 & 4 & 4 & 214.1 & Anti-icing \\
\hline
\end{tabular}

